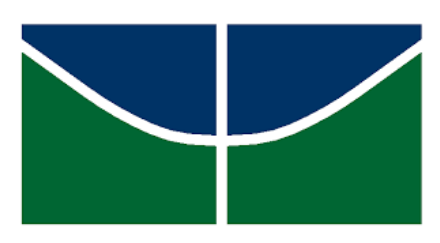

Universidade de Brasília

Instituto de Letras

Departamento de Linguística, Português e Línguas Clássicas

Programa de Pós-Graduação em Linguística

\title{
Do Logocentrismo à Multimodalidade: \\ Uma Análise Crítica \\ da Comunicação Política \\ da Câmara dos Deputados do Brasil
}

Rosane Queiroz Galvão

Brasília

2015 


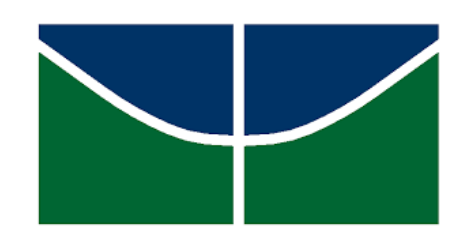

Universidade de Brasília

Instituto de Letras

Departamento de Linguística, Português e Línguas Clássicas

Programa de Pós-Graduação em Linguística

\section{Do Logocentrismo à Multimodalidade: Uma Análise Crítica da Comunicação Política da Câmara dos Deputados do Brasil}

Dissertação apresentada ao Programa de PósGraduação em Linguística, do Departamento de Linguística, Português e Línguas Clássicas, da Universidade de Brasília, como requisito para obtenção do Grau de Mestre em Linguística, na área de concentração Linguagem e Sociedade, na linha de pesquisa Discurso, Representações Sociais e Textos.

Orientadora: Profa. Dra. Janaína de Aquino Ferraz.

\section{Rosane Queiroz Galvão}




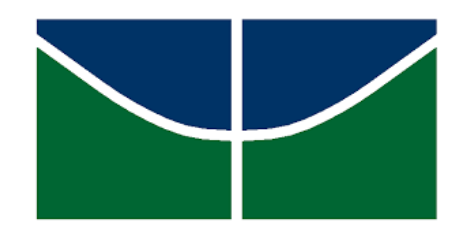

Universidade de Brasília

Instituto de Letras

Departamento de Linguística, Português e Línguas Clássicas

Programa de Pós-Graduação em Linguística

BANCA EXAMINADORA

Professora Doutora Janaína de Aquino Ferraz

(Presidente)

Professora Doutora Francisca Cordélia Oliveira da Silva

(Membro Efetivo Interno)

Professor Doutor Harrison da Rocha

(Membro Efetivo Externo)

Professora Doutora Viviane Cristina Vieira Sebba Ramalho

(Membro Suplente) 
"O Criador começa, e a criatura acaba a criação de si própria."

Rui Barbosa, em Oração aos Moços. 


\section{AGRADECIMENTOS}

À minha orientadora e amiga Prof ${ }^{a}$. Dr ${ }^{a}$. Janaína de Aquino Ferraz agradeço o convite, a inspiração, a confiança e o exemplo de dedicação à lida acadêmica.

E agradeço aos meus pais, Galvão e Telma, seres humanos geniais, que nos ensinam a todos o valor da simplicidade, da alegria e do amor.

À minha irmã, Jacqueline, cuja inteligência e beleza admiro, muito mais do que ela poderia jamais supor.

Aos meus irmãos, Júnior, André e Zeca, meus ídolos e guardiães.

Aos meus sogros Cota e Maura, em cujos braços me tomaram como filha e sem os quais boa parte de nossos sonhos pereceriam irrealizáveis.

Ao meu forte e amado companheiro Fábio Marreco, que de todas as formas me instiga e inspira a ser melhor a cada dia.

Às minhas filhas, Johanne e Bruna, às quais dedico todo o meu afeto e esforços para deixar-lhes como legado o meu testemunho - ainda que modesto - do valor inestimável do estudo, do trabalho e da caridade.

À minha pequena netinha, a doce Sofia, a quem terei a honra de chamar de doutora. 


\section{RESUMO}

Esta pesquisa transdisciplinar tem como objeto de estudo a comunicação política institucional no âmbito do Parlamento Brasileiro, na Era das Mídias e da Cultura Digital (SANTAELLA, 2003). Por meio da análise discursiva e multimodal dos recursos semióticos que se integram em textos de uma exposição histórica intitulada Parlamento e Democracia - mostra que se fez presente nos corredores da Câmara dos Deputados do Brasil entre fevereiro e abril de 2015 —, busca-se compreender os meandros político-ideológicos imbricados em gênero discursivo caracterizado, a um só tempo, por elementos das esferas política, midiática e cultural. Tal movimento implica o descortino de questões afeitas à interdiscursividade e à intertextualidade, a estratégias de operação da ideologia, à construção de significados semióticos socialmente motivados. Ademais, os textos produzidos pela Secretaria de Comunicação Social da Câmara dos Deputados inserem-se num contexto sócio-histórico e cultural marcado por fenômenos como a multimodalidade e a convergência cultural (convergência das mídias), que se unem a outros elementos da Ordem do Discurso (FOUCAULT, 2006) para delimitar o gênero do discurso da mídia estatal. Neste, as dissensões ideológicas parecem mitigadas, ou pelo menos obscurecidas, por interesses mais perenes, como a própria defesa do Parlamento e dos ideais democráticos da República Federativa do Brasil, num ambiente de profunda crise política e econômica. Como esteio teórico-metodológico, avocam-se os princípios da Análise de Discurso Crítica proposta por Norman Fairclough (2003), da Teoria Semiótica Social Multimodal, capitaneada por Gunther Kress e Theo van Leeuwen (1996, 2001), e da Hermenêutica de Profundidade, de John B. Thompson (1995).

Palavras-chave: Multimodalidade; Análise de Discurso Crítica; Gênero do Discurso; Parlamento. 


\section{ABSTRACT}

This transdisciplinary study aims to provide awareness of institutional political communication in the Brazilian Chamber of Deputies in the Age of Media (SANTAELLA, 1996). Through discourse and multimodal analysis of semiotic resources that comprise texts from a historical and cultural exhibition entitled Parliament and Democracy - exposed in the corridors of the Chamber of Deputies of Brazil between February and April 2015 — seeks to understand the political and ideological intricacies imbricated in discursive genre characterized concurrently by elements of political, media and cultural areas. Such a move implies the insight of issues akin to interdiscursivity and intertextuality, the operating strategies of ideology, the construction of socially motivated semiotic meanings. Moreover, the texts formally drawn up by the Communications Secretariat of this Brazilian legislative house of the House of Representatives are part of a socio-historical and cultural context marked by phenomena such as multimodality and cultural convergence (convergence of media), who join other elements of The Order of Discourse (Foucault, 2006) to define the genre of the discourse of state media. In this, the ideological divisions seem mitigated, or at least obscured, however perennial interests, such as self-defense of Parliament and democratic ideals of the Federative Republic of Brazil, in an environment of profound political and economic crisis. As theoretical and methodological basis, are considered principles of Discourse Analysis Critical proposed by Norman Fairclough (2003), Theory of Social Semiotics Multimodal, led by Gunther Kress and Theo van Leeuwen (1996, 2001), and Depth Hermeneutics of John B. Thompson (1995).

Keywords: Multimodality; Critical Discourse Analysis; Gender; Parliament. 


\section{ÍNDICE DE ILUSTRAÇÕES}

Figura 1 - Capas do Jornal da Câmara, 1999-2014................................................................ 14

Figura 2 - Marcas da Cultura da Convergência na Câmara dos Deputados.......................... 21

Figura 3- Imagens da exposição Parlamento e Democracia .................................................... 22

Figura 4- Televisor utilizado na exposição Parlamento e Democracia ................................... 24

Figura 5- Documentário Parlamento e Democracia, no site da Câmara dos Deputados....... 24

Figura 6 - Exposição Parlamento e Democracia, pelo link TV Câmara ................................ 25

Figura 7 - Exposição Parlamento e Democracia, pelo link Rádio Câmara ........................... 25

Figura 8 - Exposição Parlamento e Democracia, pelo link Cultura na Câmara .....................26

Figura 9 - Capa da obra Convergência e Integração............................................................28

Figura 10- Plano de Análise do Texto, segundo Bakhtin (1997) ........................................... 42

Figura 11 - Relação entre estrutura social, práticas sociais, eventos sociais, segundo

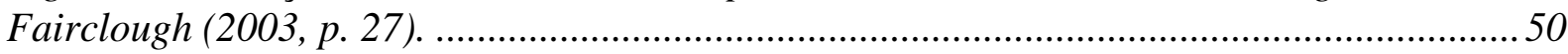

Figura 12 - Teoria Tridimensional do Discurso, com base em Fairclough, 2001, 2003. ....... 51

Figura 13 - Cotejo entre LSF e AD. Elementos da ordem do discurso.................................... 54

Figura 14 - Elementos da definição de gênero de texto, para Gunther Kress (1989)............. 64

Figura 15 - Dimensões contextuais do processo de produção do sentido, segundo Kress

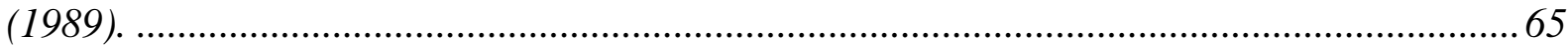

Figura 16 - Capa do Jornal da Câmara, de 19 de junho de 2013 ......................................... 71

Figura 17 - Capa do Jornal da Câmara, de 11 de agosto de 2015......................................... 72

Figura 18 - Capas do Jornal da Câmara, dos dias 10/6, 12/6 e 29/6 de 2015 ........................ 73

Figura 19 - Capa do folder da exposição Parlamento e Democracia .................................... 79

Figura 20 - Parte interna do folder da exposição Parlamento e Democracia ......................... 80

Figura 21 - Detalhes da página interna do folder da exposição Parlamento e Democracia.. 82

Figura 22 - Fotos da exposição Parlamento e Democracia .................................................. 83

Figura 23 - Instâncias da Comunicação Política, com base em Charaudeau (2006)........... 104

Figura 24 - Mapa Político do Deputado Eduardo Cunha, pelo site Atlas Político ................ 107

Figura 25 - Foto do Plenário da Câmara dos Deputados, em perspectiva. ........................... 108

Figura 26 - Foto de Bernardo Pereira de Vasconcelos ........................................................ 109

Figura 27 - Capa do folder da exposição Parlamento e Democracia ................................... 114

Figura 28 - Parte interna do folder da exposição Parlamento e Democracia ...................... 114

Figura 29 - Folder da exposição Parlamento e Democracia ................................................. 116

Figura 30 - Reprodução de óleo sobre tela, de Oscar Pereira da Silva, 1922 (Museu

Paulista), como detalhe da parte interna do folder da exposição Parlamento e Democracia.

Figura 31 - Reprodução de óleo sobre tela, de Oscar Pereira da Silva, 1922, vetorizada... 118

Figura 32 - Fotos de textos multimodais sobre a luta das mulheres pela cidadania, extraído

da exposição Parlamento e Democracia ........................................................................... 122

Figura 33 - Retrato da figura da Deputada Carlota de Pereira de Queirós no folder da

exposição Parlamento e Democracia............................................................................... 123

Figura 34 - O Parlamento e a Abolição da Escravatura ........................................................ 125

Figura 35 - Página interna do folder da exposição Parlamento e Democracia..................... 126

Figura 36 - Manifestações populares e Congresso fechado: foto da exposição Parlamento e

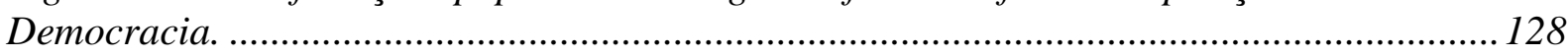

Figura 37 - Participantes representados: políticos retratados em close ............................... 129

Figura 38 - Página interna do folder da exposição Parlamento e Democracia.................... 131

Figura 39 - Os Militares no Poder: foto da exposição Parlamento e Democracia................ 132

Figura 40 - Plenário vazio: foto da exposição Parlamento e Democracia ............................ 132

Figura 41 - Atribuições do Congresso Nacional ............................................................... 134 
Figura 42 - Participante representado: Aristóteles ............................................................. 136

Figura 43 - Busto de Aristóteles (cópia romana de uma escultura de Lístios)...................... 137

Figura 44 - A intertextualidade no modo visual.............................................................. 138

Figura 45 - Participante representado: Montesquieu........................................................ 143

Figura 46 - Campanha de Eduardo Cunha à Presidência da Câmara dos Deputados, 2014.

Figura 47 - Foto de fechamento da exposição Parlamento e Democracia............................. 146

Figura 48 - Contexto da Constituição de 1946 (texto da exposição Parlamento e Democracia)

Figura 49 - Fotos de Getúlio Vargas com as mãos sujas de petróleo ................................... 148

Figura 50 - Lula com as mãos sujas de petróleo. ................................................................ 149

Figura 51 - Campanha eleitoral (2014) de Dilma Rousseff, com ênfase no pré-sal. ............151

Figura 52 - O outro negro que dará a independência do Brasil (foto da exposição)............ 152

Figura 53 - O papel da Câmara dos Deputados na campanha "O Petróleo é Nosso".......... 153

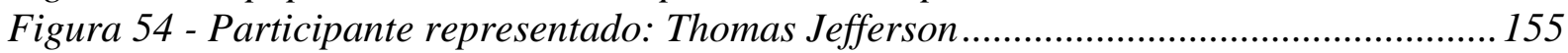

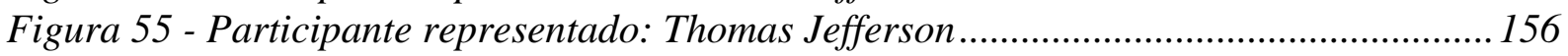

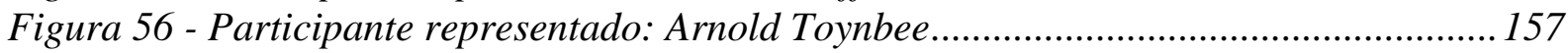

Figura 57- Participante representado: Joaquim Nabuco ................................................. 158

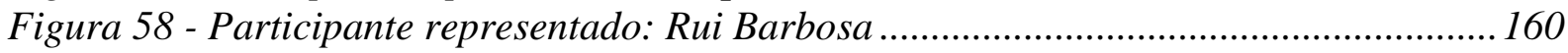

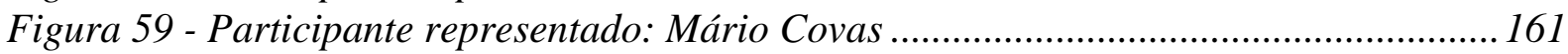

Figura 60 - Participante representado: Winston Churchill.................................................. 162

Figura 61 - Participante representada: Carlota de Queirós .............................................. 163

Figura 62 - Participante representado: Ulysses Guimarães ........................................... 165

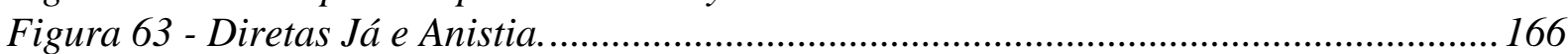

Figura 64 - Capas do Jornal da Câmara dos dias 7/1 e 26/1/2000........................................ 168

Figura 65 - Entrada da exposição Parlamento e Democracia ................................................ 170

Figura 66 - Participante representado: Padre Feijó ........................................................... 171 


\section{LISTA DE QUADROS}

Quadro 1 - Evolução do Sistema de Comunicação da Câmara dos Deputados do Brasil Quadro 2 - Tipos de implícitos, com base na Pragmática de Verschueren (1999)

Quadro 3 - Categorias de Análise da Gramática do Design Visual, com base em Kress \& van Leeuwen (1996) e Ferraz (2015)

Quadro 4 - Modos de Operação da Ideologia (THOMPSON, 2002)

Quadro 5 - Organização Metodológica da Pesquisa Qualitativa 
INTRODUÇÃO ......................................................................... 1

CAPÍTULO 1.............................................................................................. 9

1 DO LOGOCENTRISMO À MULTIMODALIDADE NO

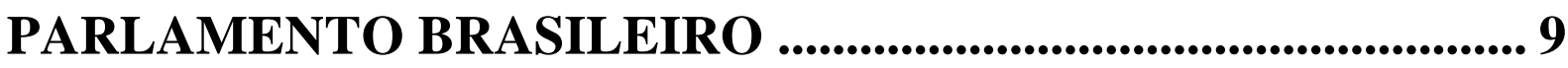

1.1 A CULTURA DA CONVERGÊNCIA NA CÂMARA DOS DEPUTADOS DO BRASIL .............................. 17

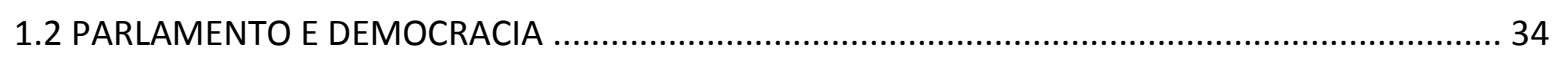

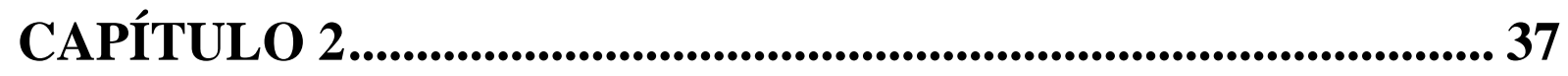

2 ESTEIOS TEÓRICO-METODOLÓGICOS ................................... 37

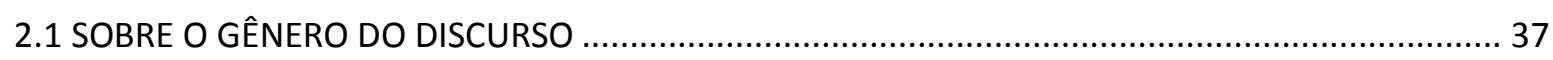

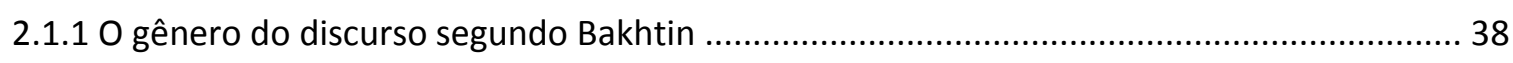

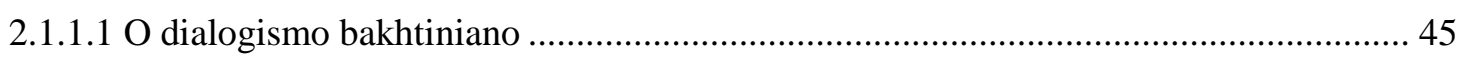

2.1.1.2 O método sociológico de análise do enunciado .......................................................... 47

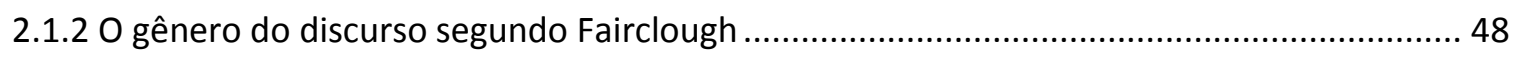

2.1.2.1 Fairclough, a interdiscursividade, a intertextualidade e a suposição............................. 56

2.1.2.2 Fairclough, hibridismo de gênero e outras tendências discursivas................................. 60

2.1.3 O gênero do texto segundo Gunther Kress................................................................. 62

2.1.3.1 Método para o estudo de gêneros textuais, consoante Kress.........................................66 66

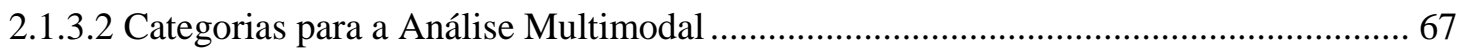

2.1.3.3 Do Princípio de Integração dos Recursos Semióticos.................................................. 70

2.2 A HERMENÊUTICA DE PROFUNDIDADE DE JOHN B. THOMPSON ............................................ 73

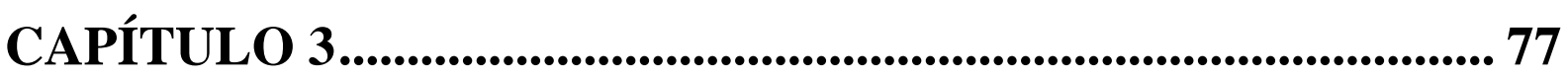

3 PROPOSTA DE MÉTODO ANALÍTICO INTEGRADO......... 77

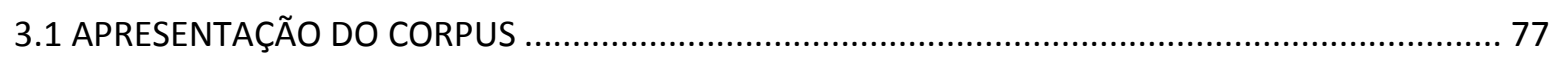

3.1.1 A exposição Parlamento e Democracia e o seu prospecto ..................................................... 78

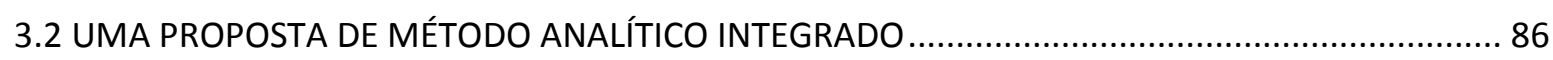

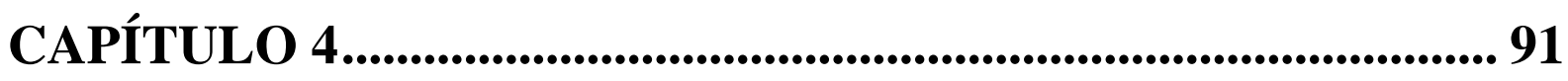

4 ANÁLISE DISCURSIVA CRÍTICA E MULTIMODAL ........... 91

4.1 O CORPUS SOB A PERSPECTIVA DO GÊNERO DO DISCURSO ............................................... 91

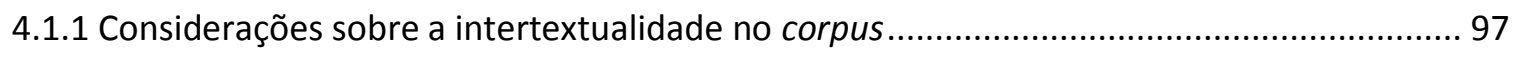

4.1.2 Dos lugares de fala dos participantes discursivos ............................................................. 100 
4.1.3 Dos elementos componentes da organização textual ...

4.1.3.1 Análise discursiva crítica e multimodal da capa e da contracapa do prospecto 113

4.1.3.2 Análise discursiva crítica e multimodal da parte interna do prospecto ..... 135

4.1.3.3 Análise discursiva crítica e multimodal dos textos exordiais da exposição 167

4.1.4 Das finalidades ou propósitos reconhecidos.

5 CONSIDERAÇÕES FINAIS ........................................................... 181

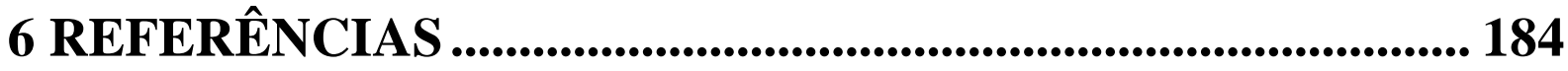




\section{INTRODUÇÃO}

O presente trabalho busca fornecer análise linguística crítica e multimodal, minuciosa e sistemática, de textos e práticas semióticas do Parlamento brasileiro, especialmente dos órgãos de comunicação da Câmara dos Deputados do Brasil reunidos na Secretaria de Comunicação Social da Câmara dos Deputados (Secom). Considerando a natureza multimodal que caracteriza grande parte dos eventos discursivos instanciados nas redes de comunicação a partir do final do século XX, pretente investigar questões específicas de gênero de discurso na comunicação política pública inserta na era da cibercultura (SANTAELLA, 1996, 2003). E o fará por meio da análise de corpus formado por textos multimodais da exposição cultural intitulada Parlamento e Democracia.

No cerne das dissensões político-ideológicas que se concentram e se concretizam no Parlamento, encontra-se a luta exasperada pela hegemonia dos significados e das representações individuais e partidárias. E tudo se dá em turbulento e perigoso momento histórico para a democracia, caracterizado por crise institucional entre os Poderes da República, mormente entre Legislativo e Executivo, ambos com baixíssima popularidade e eivados de denúncias de corrupção. E a corrupção foi apenas uma das fomentadoras das grandiosas manifestações populares em 2013 e 2015. Palavras como impeachment e cassação ganham a ordem do dia, numa crise protagonizada por políticos e doleiros, envolvidos em crimes financeiros ligados principalmente à estatal Petrobrás. Nesta empresa se vinha depositando, até então, a esperança no futuro do País, desde as primeiras extrações do petróleo nacional, em 1953, sob a presidência de Getúlio Vargas, até a descoberta recente do pré-sal, que suscitou acaloradas discussões sobre as divisões dos royalties advindos da extração do ouro negro. E à crise política soma-se outra, a econômica. Nesse turbilhão de acontecimentos, inicia-se a $55^{\mathrm{a}}$ Legislatura na Câmara dos Deputados.

Por se tratar de prática discursiva inserta em prática social que se caracteriza, a um só tempo, por elementos das esferas político-institucional, midiática e artística (conformam o corpus os textos de uma exposição cultural histórica), este é estudo multidisciplinar de gêneros do discurso, o qual, embora linguística e semioticamente orientado, socorre-se do vasto arcabouço doutrinário que compõe o pensamento social e político contemporâneo, e não se furta aos estudos hodiernos da comunicação política pública e da mídia, em particular. 
Assim, para esta análise de gênero, complexa e multidisciplinar, considerando ainda os novéis fenômenos advindos da comunicação mediada por computador - convergência das mídias, redes sociais, transparência colaborativa, participação e deliberação digital, enfim, a cultura digital —, não se podem escoimar os valiosos princípios da Teoria Semiótica Social Multimodal, capitaneada por Kress e van Leeuwen (1996, 2001, 2010), para a análise do gênero textual e dos textos em modo imagético; da Análise de Discurso Crítica proposta por Fairclough (1989, 2001, 2003 e 2006), para a consideração dos elementos das práticas sociais, mediadoras da estrutura e dos eventos sociais; e da Hermenêutica de Profundidade e sua versão para a Interpretação da Ideologia, de John B. Thompson (1995).

Antes de apresentarmos as questões definidoras de nosso problema de pesquisa - e contando com o supedâneo de Jürgen Habermas (1984) e suas ponderações acerca das transformações na esfera pública —, explicitamos alguns pressupostos, para não incorrermos em falácia argumentativa.

Tomamos como verdadeira e válida a reflexão de que tem havido alterações na estrutura da esfera pública e na comunicação pública; por conseguinte, não se furta a tais mudanças a produção midiática do Parlamento brasileiro. E isso implica evolução na própria ordem do discurso (FOUCAULT, 2006) e nos gêneros discursivos, com base em fenômenos sociais e discursivos como a convergência das mídias e a multimodalidade - esta que é fenômeno e teoria, ou, segundo Kress (2010, p. 54), campo de trabalho e, ao mesmo tempo, domínio a ser teorizado. De fato, vislumbramos, a priori, um desfoque ou blur nos limites definidores dos gêneros ligados à esfera política, ao tempo em que notamos maior ocorrência e integração de modos semióticos não verbais nos textos da mídia legislativa.

Enfim, há mudanças nas práticas discursivas, mudanças a serem escrutinadas, assim como há importantes e recentes modificações nas práticas sociais no Brasil, que vêm forçando o Parlamento a discutir reformas no próprio sistema político brasileiro ${ }^{1}$. Resta-nos entender, por meio da Análise de Discurso Crítica e seus pressupostos teóricos e metodológicos, bem assim da Teoria Semiótica Social da Multimodalidade e da Interpretação da Ideologia, como estas adversidades se relacionam às mudanças na paisagem semiótica da comunicação pública atual.

Feitas as ressalvas devidas, exsurgem os seguintes questionamentos, definidores do

\footnotetext{
${ }^{1}$ A Comissão Especial destinada a proferir parecer à Proposta de Emenda à Constituição no ${ }^{\circ}$ 182, de 2007 (e apensadas), do Senado Federal, chamada PEC da Reforma Política, foi criada em 4 de fevereiro de 2015.
} 
problema de pesquisa:

i. Os fenômenos da convergência digital e da multimodalidade refletem alterações da ordem do discurso e do gênero do discurso da mídia político-institucional?

ii. Como a inserção de novos recursos semióticos na comunicação pública, para além da modalidade verbal da linguagem, vem provocando alterações na produção, na distribuição e no consumo dos textos midiáticos da Câmara dos Deputados do Brasil?

iii. Estratégias discursivas e recursos semióticos possibilitam que se entenda a democracia como elemento de constrição da ordem do discurso político institucional?

Consentâneo com os problemas apontados, o objetivo geral se apresenta: colima-se proceder à análise sistemática dos gêneros do discurso atrelados a práticas semióticas ou textos exarados pelos órgãos de comunicação da Câmara dos Deputados do Brasil, considerando a natureza multimodal que caracteriza grande parte desses eventos discursivos, com o fito último de ampliar o entendimento de questões linguístico-discursivas específicas da comunicação pública no Poder Legislativo, em particular naquela Casa de Leis.

Como objetivos específicos, conforme apontam os problemas de pesquisa, elencam-se os seguintes:

i. identificar as alterações havidas em termos de ordem de discurso em âmbito institucional, bem assim aquelas relevantes para a delimitação do gênero discursivo moldado pelas práticas sociais inerentes às atividades do Parlamento, considerando sobretudo os fenômenos da multimodalidade e da convergência digital;

ii. identificar, descrever e analisar modos semióticos verbais e não verbais empregados na comunicação política pública, considerando mudanças históricas na produção, na distribuição e no consumo de textos da mídia parlamentar;

iii. identificar, descrever e analisar estratégias discursivas e recursos semióticos que poderiam caracterizar a democracia — sistema político ou regime de governo - como elemento do gênero discursivo.

Em face dos fenômenos que se vêm testemunhando desde o final do séc. XX fenômenos como o deslocamento do modo escrito do centro da interação social e cultural (o 
vaticinado ocaso do logocentrismo), substituído pela comunhão de diversos modos semióticos, inclusive e principalmente os não verbais; e fenômenos como a já trivialmente chamada convergência de mídias ou convergência cultural —, surge nova demanda em pesquisa linguística, e este estudo se desenvolve no sentido de atender a esse reclame. Portanto, a relevância deste trabalho repousa justamente no que há de comum a todos os coevos estudos críticos do discurso, pois nos permitem alargar o discernimento acerca da função do discurso na comunicação social nesta era da cultura das mídias e da cultura digital (SANTAELLA, 1996, 2003), bem assim dos papéis que as práticas discursivas vêm exercendo nas representações e interações da sociedade na modernidade tardia (FAIRCLOUGH; CHOULIARAKI, 1999).

Mas ousamos dizer que esta tarefa ganha relevo no presente trabalho, e o justifica, pois, por meio da análise semiótica e linguística, cuida-se de temas caros não só à população brasileira mas também aos demais povos do mundo: parlamento, democracia, legitimidade, representação política, comunicação política, ideologia, informação, transparência, opinião pública, participação, mídia estatal, mídia digital. Todos os conceitos encontram-se insculpidos no e pelo discurso do Parlamento, os quais definem, em última instância, as conformações do estamento social e do ordenamento jurídico da Nação brasileira. O entendimento dos fenômenos linguísticos ligados ao gênero do discurso é fonte para a compreensão do contexto sócio-histórico que os engendra.

Vale acrescentar que a autora desta pesquisa ocupa o cargo de Taquígrafa Legislativa na Câmara dos Deputados do Brasil desde 1996, portanto há quase 20 anos. Lá exerce a função de Revisora de Pronunciamentos. Tal labor lhe permite visão êmica, privilegiada, da questão discursivo-semiótica em apreço, além de instigá-la ao aprofundamento dos conhecimentos linguísticos e semióticos em Análise de Discurso Crítica e em Teoria Semiótica Social, de elevado préstimo ao engrandecimento do seu trabalho e, por certo, em proveito do trabalho do próprio Parlamento.

Como base global para a pesquisa empírica do gênero discursivo dos textos produzidos pelos órgãos de comunicação da Câmara dos Deputados, recorremos particularmente à construção teórico-metodológica inserta na Teoria Semiótica Social da Multimodalidade (TSSM), de Gunther Kress e Theo van Leeuwen (2001), mas não dispensamos a colaboração da Teoria Tridimensional (e bidimensional) do Discurso, da Análise de Discurso Crítica (ADC) de Norman Fairclough (2001, 2003), e da Hermenêutica 
de Profundidade (HP), de John B. Thompson (1995), teorias já citadas.

A teoria proposta pela Análise Crítica de Discurso desenvolvida por Norman Fairclough (1989, 2001, 2003, 2006), que focaliza a linguagem do Novo Capitalismo, concebe o discurso como prática social, e seu método analítico permite que a análise da produção, da distribuição e do consumo de textos multimodais se faça por meio da investigação dos elementos de ordens de discurso: do gênero (significado acional), que permite a análise das atividades e das relações sociais até a investigação das tecnologias de comunicação; do discurso (significado representacional), que possibilita o entendimento das disputas pelos significados, especialmente as que ocorrem no âmbito político-parlamentar; e do estilo (significado identificacional), que esteia o trabalho de delineação da identidade institucional do Parlamento brasileiro no atual quadro conjuntural do País e do mundo.

Não obstante se tenham em conta para o trabalho todos os significados discursivos relacionados à ordem de discurso, a ênfase recairá sobre o significado acional do texto, que guarda vinculação com a questão do gênero discursivo e categorias de análise como intertextualidade e suposição, no âmbito da prática social e discursiva, conforme a Teoria Tridimensial do Discurso, de Fairclough (2003). Assim, é preciso assinalar, de pronto, que apenas pontualmente e complementarmente se procederá, em relação aos textos do modo escrito, a microanálises gramaticais e lexicais.

No entendimento de Fairclough (2001), as formas de ação e interação em eventos sociais definem-se pelas práticas sociais e modos como estes se organizam em redes de comunicação. E as ordens de discurso, associadas com redes de práticas sociais, especificam relações particulares em cadeias de gêneros e tessituras entre tipos de texto.

No que diz respeito às lutas hegemônicas, assevera Fairclough (2001) que a capacidade de influenciar ou controlar processos de mediação é aspecto importante do poder nas sociedades contemporâneas - não é coincidência que 30\% dos congressistas brasileiros são, eles próprios, concessionários de serviços públicos de rádio e $\mathrm{TV}^{2}$. Coaduna-se com o entendimento de Fairclough o do sociológico John B. Thompson (1995), a quem também recorremos para o desvendar das ideologias que perpassam os gêneros ligados às produções da mídia político-institucional da Casa de Leis.

\footnotetext{
${ }^{2}$ Dados obtidos do instituto Observatório da Imprensa. Disponível em: $<$ http://observatoriodaimprensa.com.br/congresso-em-lisboa/conceitos-de-servico-publico-media-estatais-eprivados/?> Acesso em: 25 out. 2015.
} 
O discurso político, realizado no texto, determina as alterações no quadro das lutas hegemônicas travadas socialmente e, ao mesmo tempo, é determinado pelas dissensões nas relações de poder, exsurgidas das assimetrias sistemáticas que compõem a estrutura do campo social. Tomando como instrumental a Hermenêutica de Profundidade (HP) e a sua versão para a Interpretação da Ideologia (II), percorreremos os três caminhos propostos por este método: a análise sócio-histórica, a análise formal-discursiva e a interpretação e reinterpretação. Estes procedimentos de análise norteiam a organização "macro" ou global da pesquisa, que se inicia justamente com a contextualização social, histórica e cultural dos textos analisados no presente trabalho, bem assim o delineamento do contexto situacional.

Tal vereda coincide com a análise contextual e situacional proposta pela novel Teoria Semiótica Social Multimodal de Gunther Kress e Theo van Leeuwen (inspirados em Halliday, 1985), que veio substituir-se à Semiologia tradicional e que, segundo Vieira (2007, p. 10),

[...] pretende chamar a atenção para todas as formas de significação da atividade social, marcadamente no campo da política e das estruturas de poder, nas quais há distintos interesses por parte daqueles que produzem textos.

A partir da incorporação, pelos semióticos sociais, da imagem aos estudos da linguagem, revela-se uma perspectiva até então inédita para a Análise Crítica de Discurso, perspectiva bem investigada por Kress, Leite-Garcia e van Leeuwen (2000) no artigo Semiótica Discursiva, por meio do qual asseveram que o componente ideológico da produção textual torna-se indispensável ao estudo do signo. E este nosso estudo considera a multimodalidade, a um só tempo, fenômeno e teoria. Como teoria, fornece categorias de análise indispensáveis ao estudo dos signos e dos recursos semióticos e linguísticos em textos multimodais (MARCUSCHI, 2008) da mídia parlamentar.

Para estudar os gêneros e as relações entre as estruturas e os processos de comunicação da instituição Câmara dos Deputados, suas condições sociais, políticas e culturais, funções e implicações sobre as estruturas de texto e o uso da linguagem verbal e das imagens, é relevante ressaltar os benefícios desta triangulação teórico-metodológica que se propõe para a investigação. Van Leeuwen e Jewitt (2004) aduzem que os elementos de diferentes abordagens podem combinar-se de acordo com as demandas de projetos de pesquisa específicos. Consideramos a triangulação teórico-metodológica bastante seminal para a análise crítica e multimodal de discurso voltada à investigação de textos midiáticos, principalmente tendo em vista que todas estas teorias e seus autores privilegiam estudos 
orientados para o entendimento da comunicação de massa, que se deriva e evolui, conforme Santaella (1996, 2003), para a cultura das mídias e da cibercultura.

Enfim, resta-nos esclarecer que, como base empírica, analisamos amostras de textos multimodais produzidos pela Secretaria de Comunicação Social da Câmara dos Deputados (Secom) para a exposição cultural e histórica intitulada Parlamento e Democracia, promovida pela Secom com o objetivo de dar as boas-vindas aos novos Parlamentares que passaram a compor a 55 $5^{\text {a }}$ Legislatura, iniciada em 2015. Trata-se de pesquisa qualitativa e intensiva, que privilegia a descrição, a comparação e a interpretação de partes extraídas do corpus. Tomamse emprestadas as palavras de Fairclough (2001, p. 12) para descrever a escolha dos textos e do método de investigação do nosso corpus de análise:

O tipo de análise de texto detalhada que eu introduzo é uma forma de análise social "qualitativa". Esse é um "trabalho intensivo" e pode ser produtivamente aplicado a amostras de material de pesquisa em lugar de grandes corpos de texto $[\ldots]$

Assim, no Capítulo 1, Do Logocentrismo à Multimodalidade, situa-se o evento social no tempo e no espaço para entender a contextualização social e histórica, bem como a situacional, que envolve o evento discursivo em apreço. Busca-se analisar como se dá, no campo dos estudos linguísticos e semióticos, a evolução de teorias logocêntricas para outras, multimodais (aqui teoria, não fenômeno). Neste ponto, enfocam-se dois fenômenos sociais, mas também discursivos e línguísticos: a multimodalidade (aqui fenômeno, não teoria) e a convergência das mídias.

No Capítulo 2, Dos Esteios Teórico-Metodológicos, apresentam-se inicialmente as construções doutrinárias de Bakhtin (1997) para a questão do gênero e do dialogismo, considerando que ao pensamento deste autor converge grande parte das teorias sociodiscusivas, sociossemióticas e sociorretóricas sobre gênero de texto e gênero de discurso. Em seguida, discorre-se acerca da construção teórica de Fairclough $(2001,2003)$ para gênero do discurso, o que suscita questões afeitas à interdiscursividade, à intertextualidade, à suposição e ao hibridismo de gêneros, preciosas para o delineamento do gênero dos textos político-institucionais. Também, para o deslindar do gênero, repassamos a elaboração teórica e metodológica de Gunther Kress (1996), indicando as categorias de análise que o autor propõe, as quais empregamos prioritariamente no estudo. De Gunther Kress emprestamos, ainda, o Princípio de Integração dos Recursos Semióticos, coração da análise empreendida. 
Finalmente, apresenta-se a Hermenêutica de Profundidade (HP) de John B. Thompson (1995), que nos fornece a definição de ideologia e serve de supedâneo à divisão global do estudo. Auxilia, ademais, a análise formal-discursiva, em que se persegue a identificação de alguns dos modos gerais de operação da ideologia.

No Capítulo 3, Proposta de Método Analítico Integrado, faz-se a apresentação do corpus e se propõe um método de análise integrado para o enquadramento do gênero dos textos multimodais, em que a metodologia arquitetada por Kress (1996) funciona como fio condutor, a orientar o trabalho de interpretação dos sentidos construídos pelos textos, que oscilam entre as esferas política, midiática, histórica e cultural.

No Capítulo 4, Análise Discursiva Crítica e Multimodal, coloca-se em prática o método proposto por Kress (1996). Identificam-se, descrevem-se e interpretam-se três elementos do gênero: os lugares de fala dos participantes discursivos, os componentes da organização textual e os propósitos ou finalidades reconhecidos e estabelecidos nos eventos sociais. Neste ponto, o Princípio de Integração dos Modos Semióticos encontra-se onipresente. Aqui se procede a um exercício constante de interpretação e reinterpretação dos elementos multimodais constituintes dos textos analisados, invocando-se, quando demandadas pelo corpus, categorias de análise tanto da ADC quanto da TSSM e da HP.

Entendemos que esmiuçar excertos desse corpus extremamente rico, formado por inúmeros textos multimodais (BAUER; GASKELL, 2002) da exposição Parlamento e Democracia, permite uma análise mais profícua e resultados mais condizentes com os nossos objetivos de pesquisa, ligados ao descortinar da ordem de discurso e dos gêneros discursivos conformadores dos textos políticos produzidos pelo Parlamento. 


\section{CAPÍTULO 1}

\section{DO LOGOCENTRISMO À MULTIMODALIDADE NO PARLAMENTO BRASILEIRO}

Preliminarmente, imperioso esclarecer como se está empregando, neste trabalho de cunho linguístico-semiótico, o termo logocentrismo. Permeando todas as doutrinas clássicas da linguagem, a tradição logocêntrica pressupõe a possibilidade de resgatar significados estáveis no texto: entende que o sujeito — de consciência plena, capaz de uma relação puramente objetiva com a realidade - somente poderia interpretar a realidade ou o texto depois de compreender a realidade ou o texto, o qual detém um significado presente, latente, imanente, independente da compreensão desse sujeito. Essa compreensão, no entanto, quando realizada adequadamente, não deveria revelar as circunstâncias nem o contexto de sua realização ou de seu realizador. E, enfim, dispensaria o trabalho de interpretação.

Como base da filosofia ocidental, o termo se refere à crença absoluta na existência de um conhecimento em estado puro, numa verdade absoluta conferida à palavra, que, não obstante o contexto ou a circunstância, poderia ser recuperada diretamente dos textos. Tal teoria foi contraposta, na França da década de 60, pelo pensamento desconstrutivista, que à época buscava lembrar ao Estado os ideais de liberdade individual e igualdade social, em oposição à frieza positivista e lógica das normas legais ${ }^{3}$.

O movimento desconstrutivista encontrou no filósofo Jacques Derrida um de seus maiores expoentes. Derrida (1971, p. 16) ousou cavar do texto uma estrutura intrínseca, "aquilo que o próprio autor não viu ou não quis ver", já que os significados de um texto se vão tecendo conforme o trabalho de cada leitor/tradutor, no momento de cada leitura. Este é o "instante da ameaça", quando se ameaça "metodicamente a estrutura para melhor a perceber, não só nas suas nervuras mas também neste lugar secreto em que não é nem ereção nem ruína mas labilidade." Rajagopalan (1992, p. 27) entende a desconstrução como "atividade

\footnotetext{
${ }^{3}$ Santiago (1976, p. 17) traduziu a desconstrução como "operação que consiste em denunciar num determinado texto (o da filosofia ocidental) aquilo que é valorizado em nome de quê e, ao mesmo tempo, em desrecalcar o que foi estruturalmente dissimulado nesse texto". Para o autor, o logocentrismo é conceito centrado no significado, "que tem o privilégio da proximidade com o logos", sendo este "a origem da verdade do ser".
} 
infindável que visa desmascarar passo a passo" a construção do significado, este sendo independente do contexto social, histórico e cultural — uma espécie de semiose infinita.

Opôs-se Derrida ao estruturalismo Saussureano e esforçou-se em restituir à escrita os atributos que o estruturalismo atribuíra à fala, descontruindo a dicotomia langue e parole, o linguístico e o não linguístico, o sincrônico e o diacrônico. Enquanto Saussure (2002) entendia o signo linguístico como aquilo que outro signo não pode ser (teoria do valor), o desconstrutivista retrucava que o significado se torna sempre um outro. A oposição de Derrida à semiologia estruturalista nos faz posicionar esta, mutatis mutandi, na esteira logocêntrica, no âmbito dos estudos linguísticos, para os quais Saussure reivindicava o status de ciência, aquela que estudaria a constituição dos signos e as leis que os regem.

Vieira (2007, p. 10) bem sintetiza a acepção particular, que ora esposamos, de logocentrismo:

Nas sociedades letradas do Ocidente, existe a crença de que a comunicação é representada exclusivamente pelas modalidades de língua escrita e oral. Esse entendimento, entretanto, tem sido contrariado por autores como Jaques Derrida (2001) e Julia Kristeva (1967), que acusam o logocentrismo de ser o pilar de estruturas patriarcais. As práticas discursivas cotidianas opõem-se a essa tradição de valorização excessiva da língua escrita e oral e, pelo seu expressivo uso, testemunham em favor da imagem como forma de comunicação mais eloquente da pós-modernidade.

Ferraz (2015) trata do assunto sob o ângulo do percurso semiótico que se inicia em Saussure e chega a Kress, "da Linguística à Semiologia”. Aduz Ferraz que, não obstante ter-se dado prolongada ênfase aos textos linguisticamente realizados, "o legado deixado por Ferdinand de Saussure aos estudos linguísticos já apontava a expansão do foco da Linguística para outros modos de linguagem".

À parte divergências de cunho filosófico e epistemológico, no centro do debate esteve sempre a palavra, a linguagem verbal — oral e escrita — , que reinou por muito tempo sem antagonista na linguística, na semiologia, na semiótica, nas gramáticas tradicionais do século XX.

Já a tradição grafocêntrica, esta milenar (o surgimento da escrita teria ocorrido por volta de 3.000 a.C), ainda vem atribuindo excessivo valor social e político, ético e moral, mas também jurídico, à linguagem escrita - uma visão dita monomodal. Desde a Grécia antiga já se privilegiava a língua escrita, conforme denuncia o fato de se ter empregado a expressão 
grega grammatiké - "a arte de ler e escrever" — para nomear justamente a disciplina que estuda a língua (NEVES, 1987, p. 105). Rocha (2012, p. 48), ao discorrer sobre as origens da gramática tradicional, ensina que os próprios estudos da linguagem nasceram de uma preocupação de filólogos, na Alexandria do século III a.C, de preservar a língua grega pura, conforme o seu emprego pelos escritores. E o clamor do grafocentrismo ainda se faz reverberar, mas já não tão incólume, nesta era de cultura digital. Mas não para Kress e van Leeuwen (1996, p. 183), que vêm vaticinando “o fim da linguagem monomodal”.

Para Santaella (2003), na história da humanidade são sutis as passagens de uma era a outra, ou, mais precisamente, de uma formação cultural a outra. Embora não lineares e complexas, estas poderiam ser divididas em seis etapas, para melhor compreensão e caracterização: a cultura oral, a cultura escrita, a cultura impressa, a cultura de massas, a cultura das mídias e a cultura digital.

É necessário esclarecer que, nessa divisão, a ênfase não recai nos meios e nas mídias (fetiche das mídias), mas nos signos, mensagens e processos de comunicação. Para a autora, desde o aparelho fonador até as redes digitais atuais, os meios de comunicação não passam de "meros canais de transmissão de informação". Assim, errônea seria a ideia de que as novas tecnologias de comunicação são as fontes exclusivas das mudanças culturais.

[...] não devemos cair no equívoco de julgar que as transformações culturais são devidas apenas ao advento de novas tecnologias e novos meios de comunicação e cultura. São, isto sim, os tipos de signos que circulam nesses meios, os tipos de mensagens e processos de comunicação que neles se engendram os verdadeiros responsáveis não só por moldar o pensamento e a sensibilidade dos seres humanos, mas também por propiciar o surgimento de novos ambientes socioculturais. (SANTAELLA, 2003, p. 24, grifo nosso).

A visão da semiótica como plasmática do pensamento e da emoção humana, capaz de irromper novas esferas socioculturais, coaduna-se com o entendimento de Bakhtin, em que aquiescemos, de que a linguagem permeia todas as atividades humanas, a vida social, e desempenha papel central na formação sociopolítica e nos sistemas ideológicos. A linguagem é pressuposto; e as mídias, elas próprias, podem constituir-se de complexos semióticos.

Contudo, não se pode perder de vista a constatação de Santaella de que os meios de comunicação motivam a multiplicação de códigos e linguagens, e que os sistemas sígnicos se conformam às potencialidades e aos limites dos meios que os veiculam. 
Processos comunicativos e formas de cultura que nelas [nas mídias] se realizam devem pressupor tanto as diferentes linguagens e sistemas sígnicos que se configuram dentro dos veículos em consonância com o potencial e limites de cada veículo, quanto devem pressupor também as misturas entre linguagens que se realizam nos veículos híbridos, de que a televisão e, muito mais, a hipermídia são exemplares. (SANTAELLA, 2003, p. 25).

De fato, não se pode desjungir as mídias das formas de socialização e cultura criadas por essas mídias, por meio dos seus processos de comunicação. Os meios carregam consigo "as contradições que caracterizam o modo de produção econômica e as consequentes injunções políticas" de cada ciclo cultural; por isso, "pode-se estudar sociedades cuja cultura se molda pela oralidade, então pela escrita, mais tarde pela explosão das imagens na revolução industrial eletrônica, etc." (Ibid., p. 25).

Ao tratar de "hipermídia", "mistura de linguagens", "veículos híbridos", embora não tenha assim nominado, a autora tangencia alguns aspectos centrais do fenômeno chamado multimodalidade - termo que, como já afirmamos no exórdio deste trabalho, refere-se tanto a um fenômeno sociocultural quanto à teoria, a Teoria Semiótica Social da Multimodalidade (TSSM). Como fenômeno social, a multimodalidade revela outros fenômenos a ela afeitos (nem todos esmiuçados neste trabalho), que dizem respeito ao presente estudo de textos multimodais exarados pela Secretaria de Comunicação Social da Câmara dos Deputados. Referimo-nos a redes sociais, participação e deliberação digital, democracia digital, transparência legislativa, democratização do discurso, tecnologização e comodificação das práticas discursivas de âmbito público institucional (FAIRCLOUGH, 2001).

Como teoria, a multimodalidade insere-se na novel Teoria Semiótica Social da Multimodalidade (TSSM), capitaneada por Gunther Kress e Theo van Leeuwen (1996, p. 33), que apontam para mudanças na paisagem semiótica, pelo uso significativo de imagens (modo imagético) em construções multimodais. Inspirados em Halliday (1994), elaboram a Gramática do Design Visual. Segundo Gunther Kress e van Leeuwen (1996), participam do fenômeno multimodal a linguagem verbal e não verbal (imagem, música, gestos, escultura, arquitetura, etc.), que são modos realizados a partir de várias modalidades sensoriais (visual, auditiva, tátil, olfativa, gustativa e cinética), que participam da construção do significado global do texto. Gunther Kress e van Leeuwen (1996, p. 20) aduzem que a Semiótica Social concebe a linguagem como prática de produção de significados, e elegem o texto (e os sentidos construídos e negociados neste) como unidade de análise, sendo o texto "duplamente 
determinado pelos significados sociais dos discursos que nele figuram e pelas formas, significados e restrições de determinado gênero" - e é justamente o gênero discursivo o enfoque deste nosso estudo.

Com base em Kress e van Leeuwen, Ferraz (2015, p. 391) afirma:

[...] as últimas décadas presenciaram mudança bastante abrangente na mídia, nos modos de comunicação. Os periódicos da década de 1960 eram impressos em preto e branco e cobertos de caracteres escritos; já os desta década são coloridos, cheios de imagens e, em muitos deles, principalmente no Ocidente, os caracteres escritos têm quase desaparecido das páginas.

Apenas como ilustração da amplitude com que o fenômeno multimodal vem alterando a linguagem nos produtos midiáticos produzidos pelo Parlamento, já na era da cultura das mídias (a partir da década de 80), colhemos seis capas de edições diferentes do diário impresso Jornal da Câmara, escolhidas aleatoriamente em um intervalo de aproximadamente 15 anos, de 1999 a 2014.

Nelas é possível vislumbrar uma evolução na linguagem, especialmente em relação ao emprego de recursos semióticos do modo imagético, em detrimento do modo escrito, o que vai alterar substancialmente a construção global dos significados representacional, interacional e composicional (KRESS, 1996). 
Figura 1 - Capas do Jornal da Câmara, 1999-2014

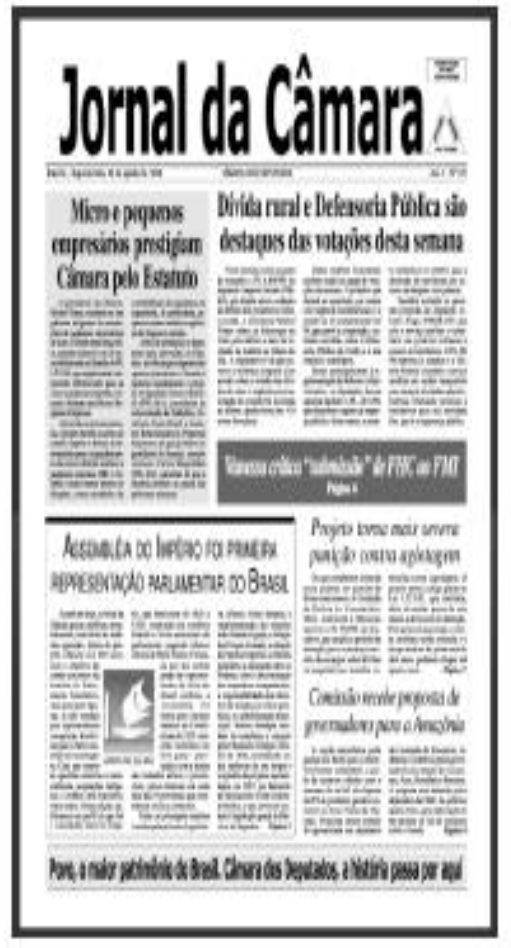

23 ago. 1999

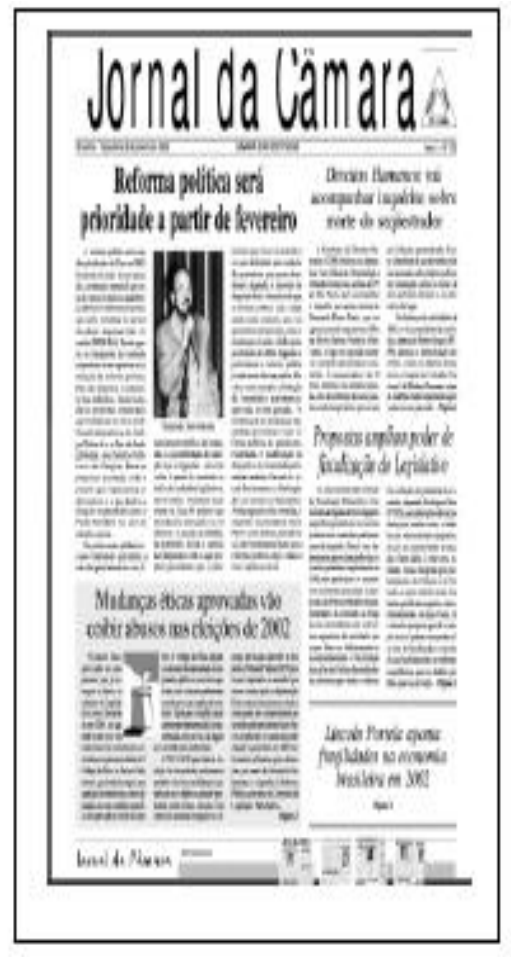

8 jan. 2002

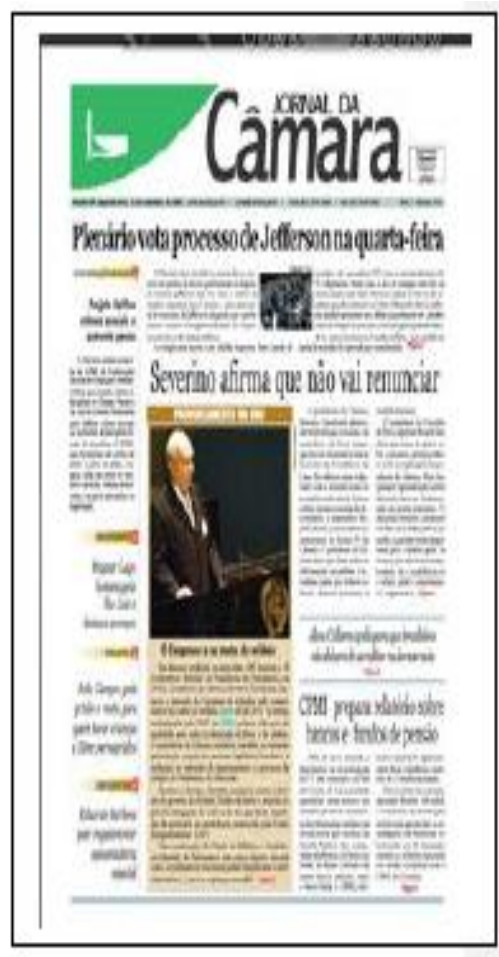

12 set. 2005

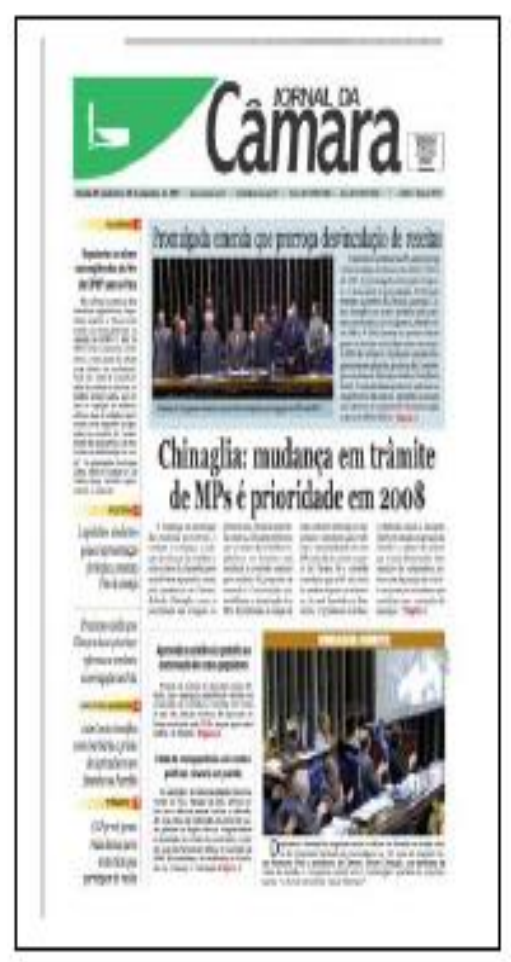

21 dez. 2007

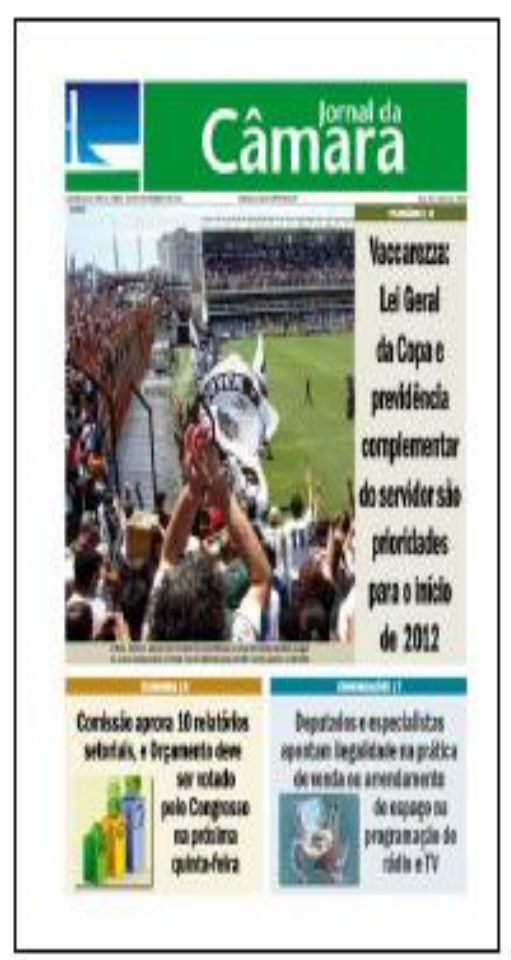

16 dez. 2011

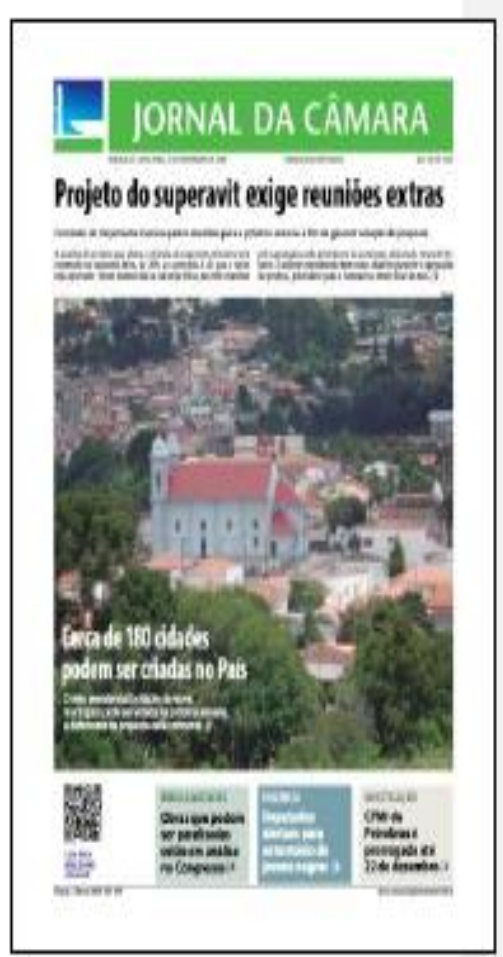

21 nov. 2014

Fonte: Página virtual da Câmara dos Deputados, link Jornal da Câmara. 
Nos textos institucionais, nota-se, nos cluster, a linguagem prevalentemente monomodal sendo substituída pela multimodal. O cluster define uma região específica ou uma sub-região da página como um todo, por exemplo, o espaço destinado à manchete em um jornal impresso, ou à legenda de uma foto ou a uma ilustração. Consiste em um conjunto local de itens, em particular em uma webpage ou página impressa (BALDRY; THIBAULT, 2006, p. 31). É justamente o critério de distribuição espacial, de proximidade, que permite a identificação de um cluster, que pode realizar-se nos modos escrito, verbal, imagético, audiovisual.

Não se pode deixar de dizer que, para a TSSM, todos os textos são multimodais. Nesse sentido, Ferraz (2015, p. 391) elucida:

[...] para eles [Kress \& van Leeuwen], embora a escrita tenha sido o mais valorizado meio de comunicação nos últimos séculos — o meio que tem regulado o acesso ao poder social nas sociedades modernas ocidentais —, é claro que outros meios de comunicação sempre existiram juntamente com a escrita. $\mathrm{O}$ que eles procuram afirmar é que a comunicação sempre foi multissemiótica e o que está acontecendo, no momento, apesar de não ser nada novo, ainda assim, é uma mudança significativa.

Essa mudança significativa a que Ferraz se refere, relaciona-se a modos radicalmente diferentes de representação. As mudanças nos textos são claramente perceptíveis e já iniciam na trajetória da leitura (BALDRY; THIBAULT, 2006, p. 116), consequência dos arranjos e rearranjos visuais, incluindo a sobreposição de recursos semióticos, a preocupação com a logomarca e os efeitos relativos à distribuição espacial, ao enquadramento, às cores, à tipografia, aos participantes representados, etc. (KRESS, 2010, p. 90-91). Essa alteração substancial no discurso e no design acompanha-se de alterações significativas na produção e distribuição dos textos da comunicação política institucional (KRESS; VAN LEEUWEN, 2001 e 2010).

São os quatro domínios da prática social (KRESS, 2010, P. 133) - discurso e design, produção e distribuição - que evoluem de forma visível, mas também em amplitude quase imensurável, nos discursos político-jornalísticos da Casa de Leis. A assunção de nova atitude pela mídia legislativa reflete o fenômeno da multimodalidade, e o realimenta, no contexto da modernidade tardia (BAUMAN, 2001).

Nesse sentido, explica Macedo (2013, p. 107, grifo nosso): 
para eles [novamente, Kress \& van Leewen], o conceito de design é crucial e é um reflexo desta era chamada modernidade tardia - era da fragmentação, da dispersão, da fluidez, da não permanência - em oposição às décadas anteriores de monomodalidade, de coesão social, de estabilidade, de delimitação clara de papéis sociais.

Para esta nossa perquirição voltada ao entendimento da profusão do fenômeno multimodal, bastante interessante é a definição de Kress (2010, p. 133) para o domínio da prática social que denomina design: processo de tradução da avaliação politicamente orientada da retórica do ambiente comunicacional para um material semioticamente moldado. Macedo (2013, p. 108) conclui que o design é, portanto, prospecto, já que responde a novas demandas: "Em vez de ser a implementação de práticas convencionalmente dadas, é transformador, logo, inevitavelmente, inovador".

Se essas argumentações se prestam à análise, ainda que perfunctória, das capas de jornais trazidas como ilustração nesta seção, servem ainda mais à análise que adiante se faz dos textos da exposição Parlamento e Democracia. Entendemos que a escolha - feita pela Presidência da Câmara dos Deputados — pela exposição de arte histórica como meio de difundir discurso substancialmente político pode ser entendida como estratégica e perfeita tradução, para um material semioticamente moldado, "da avaliação politicamente orientada da retórica do ambiente comunicacional".

Avaliar politicamente a retórica da "ambientação comunicacional" em que se divulga a exposição cultural, para traduzi-la em design, não é empreitada simples, pois há que se considerar que os efeitos dos significados construídos pelos textos verbais e imagéticos não cessam em cronotopo (BAKHTIN, 1929) fixo e determinado, estacando-se no instante em que se recolhem os materiais fisicamente expostos. Contrario sensu, expandem-se indefinidamente pelas redes de comunicação, modificam-se, recontextualizados (FAIRCLOUGH, 2003) e ressemiotizados (IEDEMA, 2003) em diferentes suportes midiáticos, inclusive e principalmente em plataformas digitais. Deixam o mundo real — uma exposição ou mostra cultural, por exemplo - e reinserem-se em ambiências comunicacionais que caracterizam mídias de massa (TV e rádio, verbi gratia) e mídias digitais (internete). Da mesma forma, podem sair do ambiente virtual e corporificar-se no mundo concreto. 
Vê-se, dessa forma, que a noção de multimodalidade incorpora outras noções relacionadas à ordem do discurso e ao gênero, como cronotopo, recontextualização, ressemiotização, ressignificação, hibridismo de gênero e textual. Todas essas noções são mais detalhadamente investigadas no próximo capítulo deste estudo.

Por fim, há que se indagar se o fenômeno da multimodalidade representa, finalmente, o ocaso do logocentrismo (a palavra no centro), ou pelo menos do grafocentrismo (a escrita no centro). Com o aval de Santaella (2003), entendemos que se pode vislumbrar certo realinhamento ou talvez a recomposição deste centro. O que se testemunha na verdade, na era da cultura digital (a cultura do acesso), é "caldeamento denso e híbrido", em que persistem fortes as comunicações escritas e orais, ao lado dos também poderosos modos semióticos visuais e audiovisuais. Outrossim, também a cultura de massas e a das mídias permanecem "em plena atividade", a par da cultura digital.

Dessa forma, pode-se antever que, tal como a inserção da escrita gerou e ainda vem gerando culturas letradas (BOLTER, 1991), "a introdução da escrita eletrônica conduzirá a uma cultura eletrônica, com uma nova economia da escrita" (MARCUSCHI, in MARCUSCHI \& XAVIER, 2010, p. 17).

Mas para Santaella (2003a) a grande marca da cultura digital é a convergência das mídias, "que tem sido responsável pelo nível de exacerbação que a produção e circulação da informação atingiu nos nossos dias". Na próxima seção, vamos tratar justamente do fenômeno da convergência das mídias, ou convergência digital, e de sua repercussão concreta, na própria estrutura administrativa da Câmara dos Deputados do Brasil e em suas práticas discursivas.

\subsection{A CULTURA DA CONVERGÊNCIA NA CÂMARA DOS DEPUTADOS DO BRASIL}

Na seção anterior, pôde-se ilustrar, por meio do cotejo de capas do jornal impresso da Câmara dos Deputados, a afluência de mudanças significativas na produção daquele órgão da mídia estatal nos últimos 15 anos, relativas ao fenômeno da multimodalidade. Naquelas, e em muitas outras publicações oficiais, observa-se a ocorrência/concorrência de recursos 
semióticos multimodais (modos escrito, imagético, sonoro, audiovisual). Essa evolução significativa da linguagem jornalística legislativa é reflexo, também, de outro fenômeno social e discursivo: a cultura da convergência.

Nesta seção, busca-se compreender melhor não só o significado da convergência como nova prática social e discursiva, inclusive no âmbito da comunicação social daquela Casa de Leis, mas principalmente entrever a amplitude das mudanças em andamento e vindouras, pois que o fenômeno mal acaba de sair de seu nascedouro.

Vale assinalar que, embora os textos analisados neste estudo não tenham como suporte páginas virtuais - são textos de exposição histórica de arte —, é fulcral o entendimento dos efeitos da cultura da convergência na Câmara dos Deputados para que se possa compreender a evolução, o alcance, a atual magnitude dos órgãos de mídia daquela instituição, produtora e principal difusora dos textos ora sob investigação, e de seus produtos.

Tais como os demais produtos dos órgãos da mídia institucional, os textos que conformam a exposição Parlamento e Democracia reproduziram-se e ainda se reproduzem (por tempo indefinido) como conteúdo das mídias de massa de que a Câmara dos Deputados tornou-se detentora, como rádio e TV, além de todos os canais disponíveis em sua mídia digital.

No excelente compêndio intitulado Teoria das Mídias Digitais, Martino (2014, p. 36) argui que a noção de convergência parte do princípio de que "as diferentes mídias tendem a ser agregadas e ressignificadas na experiência dos indivíduos, gerando novas aticulações na maneira como esses fenômenos são vivenciados". No contexto dos órgãos midiáticos públicos estatais, repercussões concretas da cultura da convergência já se fazem presentes como nova prática discursiva e social.

Com efeito, já se tem noticiado há pelo menos quatro décadas relevante e complexa tendência de mudança nas práticas sociais contemporâneas, alteração que se revela nas práticas discursivas e no modo como os textos vêm sendo produzidos, distribuídos e consumidos (FAIRCLOUGH, 2001). Em grande parte, tais alterações se devem à cultura da convergência. Não obstante esteja sendo bastante evocado nos estudos comunicacionais sobre mídias, mormente mídias digitais, mas quase nada nos estudos linguísticos e semióticos (à exceção dos trabalhos inéditos de FERRAZ, 2007, 2011, 2015), o fenômeno não é de tão 
simples entendimento. Nesse sentido, auxilia-nos Martino (2014, p. 34), ao procurar elucidar o alcance do termo:

Essa relação entre pessoas que não se conhecem, mas dividem as mesmas referências, recriando as mensagens da mídia (e tornando-se, elas mesmas, produtoras) e compartilhando ideias espalhadas entre vários meios de comunicação em várias plataformas, é um dos elementos do que Henry Jenkins denomina cultura da convergência.

Das palavras transcritas, nota-se que a convergência de que tratamos não se resume à dimensão tecnológica que se costuma atribuir ao termo (no que Santaella é acorde). Esta seria apenas um dos aspectos da convergência, relevante, mas não exclusivo nem central. A ênfase excessiva a essa dimensão tecnológica produziria o que Henry Jenkins (2009 apud MARTINO, 2014) intitula a "falácia da caixa-preta". Para o autor, seria a quimera de unir, em um único dispositivo ou aparelho - a chamada caixa-preta - as funções do computador, da televisão, do telefone, da câmera fotográfica, do vídeo e outros que futuramente possam advir. Para Jenkins, o termo "convergência", sozinho, refere-se ao fluxo de informações entre vários suportes midiáticos, que mantêm suas respectivas especificidades.

Ao se tratar da dita cultura da convergência, também alcunhada de convergência cultural, é justamente a dimensão cultural que, de fato, define o termo. Este é nosso entendimento. Recorramos novamente às palavras de Martino (2014, p. 35), que, até certo ponto, robora essa compreensão:

A convergência é um processo cultural que acontece na mente dos indivíduos na medida em que podem ser estabelecidas conexões entre os elementos da cultura da mídia, isto é, das mensagens que circulam nos meios de comunicação, e a realidade cotidiana. Em seu nível mais simples, quando alguém vê uma pessoa na rua e a acha parecida com algum personagem de uma série de TV, é um momento de convergência [...]

Não nos seria útil discutir à sobejidão a definição de convergência cultural proposta por Martino e inspirada em Jenkins, embora tenhamos impressão priorística de que restringir esse "processo cultural" a algo que "acontece na mente do indivíduo" seria um tanto reducionista, e também destoante da linha de análise crítica multimodal que desenvolvemos - esta que de fato nos importa -, cujos preceitos nos impingem a tratar a linguagem por meio de abordagem não meramente formalista ou interna, mas essencialmente funcional ou externa (cf. SCHINFFRIN, 1994). 
Mas por que, então, avocamos as lições de Martino e, por seu intermédio, o pensamento de Henry Jenkins? Porque destes, algumas considerações nos interessam em especial, ligadas às práticas sociais, discursivas e textuais (FAIRCLOUGH, 2001, p. 101) no contexto da nova ordem tecnológica, de que também o Parlamento é parte.

A primeira consideração consiste mesmo na ênfase ao "processo cultural", em detrimento de um enfoque exclusivamente tecnológico da expressão convergência cultural. E, no âmbito desse processo cultural, destacamos a menção à "cultura da mídia” e às conexões entre "as mensagens que circulam nos meios de comunicação" e a "realidade cotidiana". Os textos que analisamos neste trabalho pertencem ao domínio de um órgão da mídia estatal, que é não só partícipe mas protagonista de um processo de construção cultural e ideológica hegemônica.

Trata-se de um Poder constituído, cujas mensagens diárias carregam a chancela da oficialidade, que lhes confere não só prestígio mas também legitimidade institucional. Assim, fazem parte de um processo cultural planeado por um dos Poderes do Estado as mensagens que se emitem por todos os órgãos de comunicação da Casa de Leis e as que por ali circulam. E estas, privilegiadas, impregnam-se de oficialidade e legitimidade.

A webpage da Câmara dos Deputados, exempli gratia, mostra marcas semióticas desse apanágio. Para Baldry e Thybault (2006, p. 104, grifo do original), "uma webpage é uma unidade viso-espacial exibida em uma tela de computador. [...] vai além da página impressa por sua natureza hipertextual e a ação potencial que esta proporciona". Na imagem abaixo, visualiza-se a página inicial do site da Câmara dos Deputados. Nela, fazemos duas ênfases.

Primeiro, assinalamos, por meio de setas, os recursos semióticos dos modos escrito e visual que certificam o caráter oficial dos textos: a logomarca; a imagem do Congresso, sob a perspectiva da Câmara dos Deputados, pois à direita se desponta em saliência a semiesfera ou prato virado para cima, que representa aquela Casa de Leis e é o maior símbolo da Capital do País; a bandeira do Brasil, sempre proclamada como símbolo de identidade nacional, estratégia de construção simbólica relativa a modo de operação ideológica chamada por John B. Thompson (1995) de unificação; a imagem do plenário, representado a partir de um ponto de vista (KREES; VAN LEEUWEN, 1996) superior e centralizado, não tendendo nem para a esquerda nem para a direita, o que simboliza imparcialidade política.

Segundo, circulamos componentes que se enchapelam sob o link "Comunicação", a 
testemunhar a convergência dos veículos da mídia institucional. Essa "espécie de narrativa de múltiplas potencialidades criada pela sinergia entre diversos gêneros multimídia, como a trajetória do hipertexto passa a revelar", é definida por Baldry e Thibault (2006, p. 126) como "cascata semiótica".

Figura 2 - Marcas da Cultura da Convergência na Câmara dos Deputados

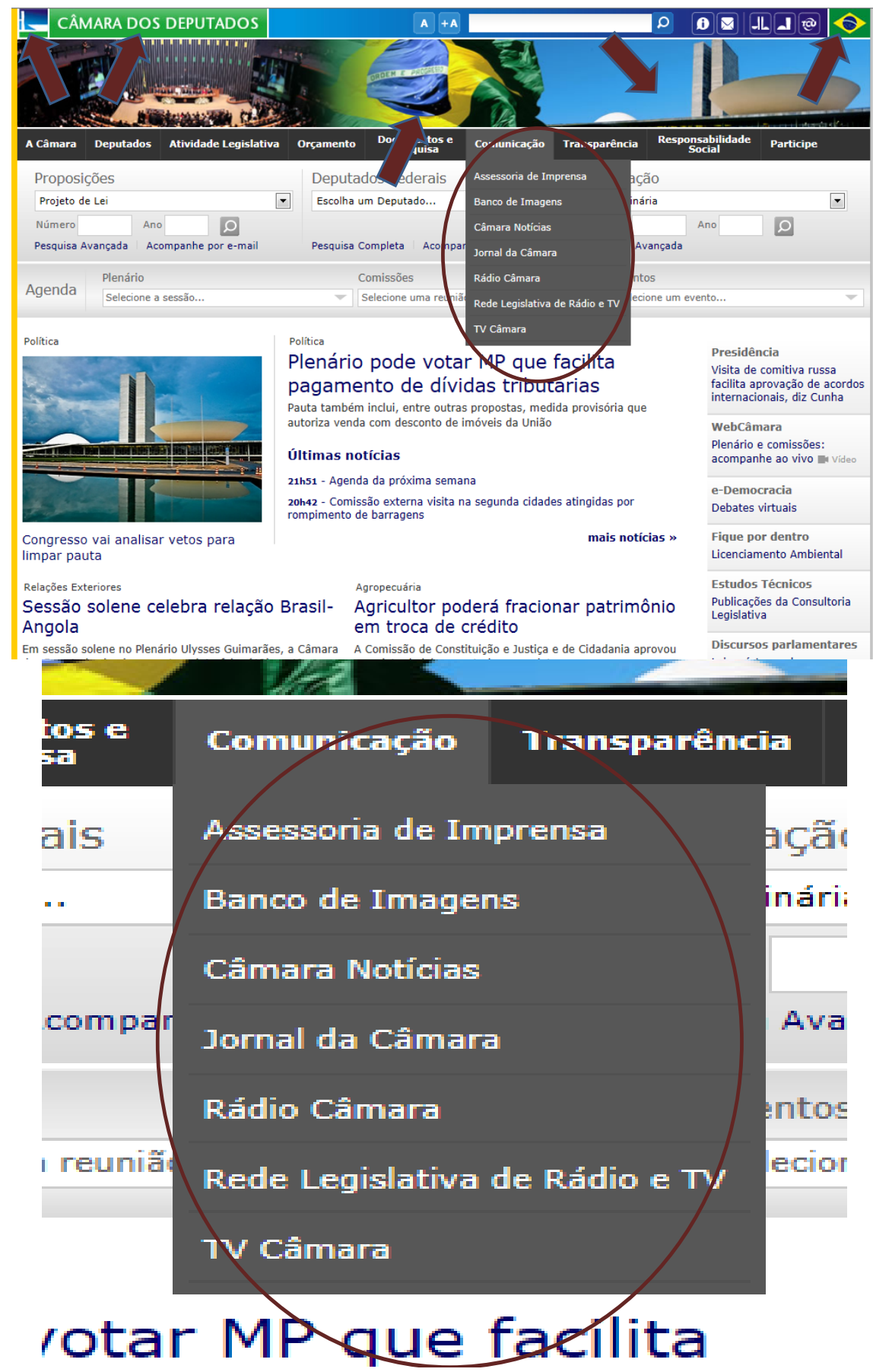

Fonte: Disponível em: <http://www2.camara.leg.br/>. Acesso em: 14 nov. 2015. 
Novamente segundo Baldry e Thibault (Ibid., p. 104), a webpage faz uso de "recursos escritos como a língua e de recursos de representação incluindo a justaposição espacial de objetos". Interessante perceber que a exposição que serve de corpus de análise para este estudo, como um rico exemplo dessa convergência cultural - que o termo "híbrido" bem traduz —, apresenta-se composicionalmente como uma emulação das sobreposições espaciais de objetos que caracterizam as webpages.

\section{Figura 3- Imagens da exposição Parlamento e Democracia}
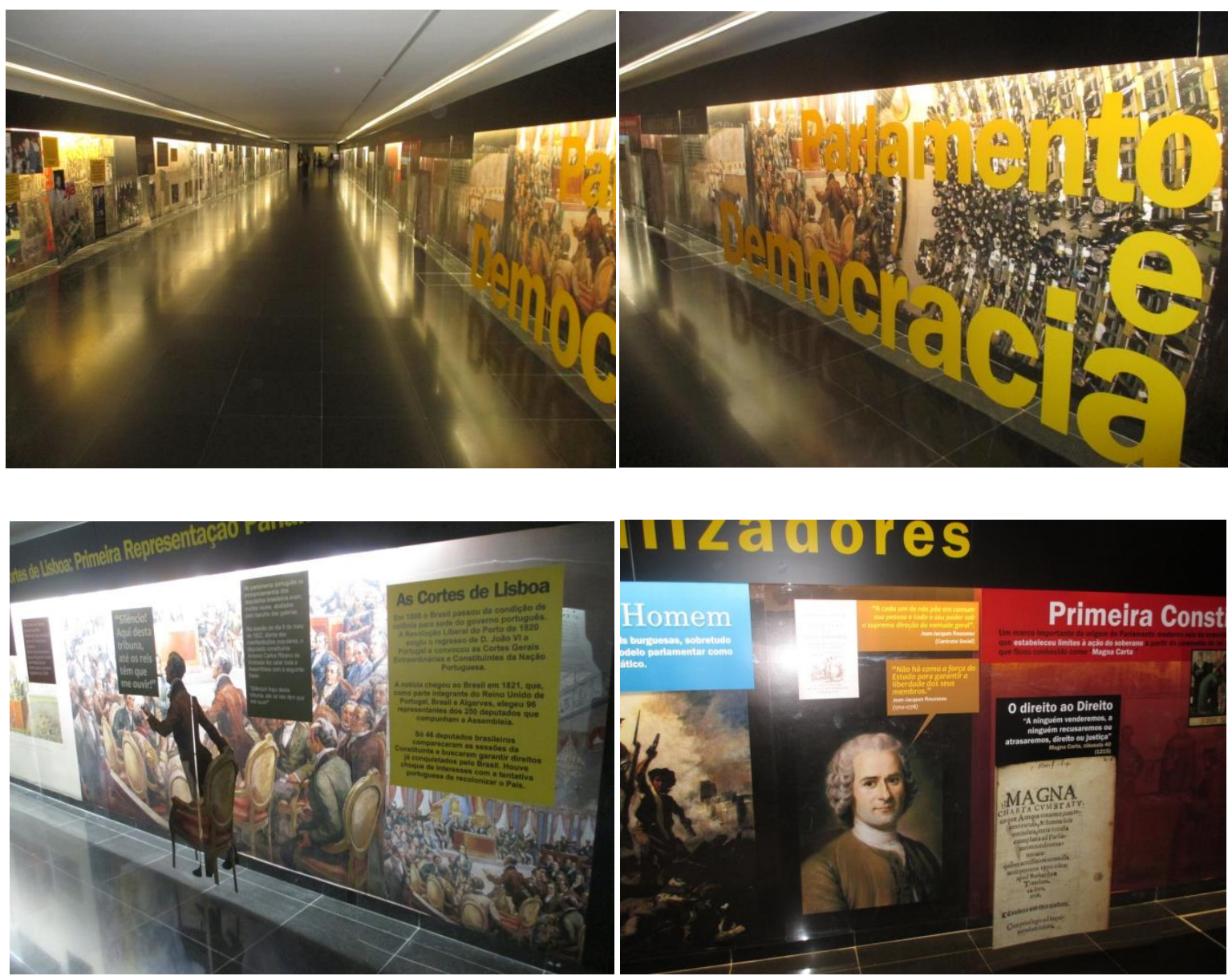

Fonte: Acervo de fotos da autora deste trabalho.

Um olhar atentamente dirigido às fotos possibilita que se entenda como se fez o arranjo visual: em cada uma das paredes do corredor, uma oposta à outra, foram colados pôsteres com textos escritos e imagéticos, que cobriam as paredes de cima a baixo. $\mathrm{Na}$ frente das paredes, paralelamente a estas, tal como se fosse uma cortina transparente, foi esticada uma lona de 
vinil translúcida, para sobrepor aos textos já colados na parede outros textos. Nesta "cortina transparente", por exemplo, replicavam-se imagens da parede, que geravam a sensação de tridimensionalidade, conforme se caminhava pelo corredor. Por exemplo, o título da exposição, Parlamento e Democracia, foi apresentado no vinil transparente, e por detrás se podiam ver duas grandes imagens: a do Plenário atual e a do de 1822, ainda em Lisboa.

$\mathrm{Na}$ cortina transparente também se abriam "balões" de fala para as personagens retratadas na parede, linguagem típica de revistas em quadrinhos. Já se anteveem, neste momento do estudo, a intertextualidade, a ressemiotização, a recontextualização, a serem enfocadas com profundidade em capítulo adiante, quando se procede à análise formaldiscursiva.

Ademais, na exposição cultural e histórica, emolduravam-se, em quadrados ou retângulos, os textos explicativos das imagens que estavam por trás do vinil transparente, como que a imitar as telas touch scream dos smartphones e tablets, instigando o visitante a tocar com a mão o texto no vinil, para poder melhor enxergar as imagens que por trás dele se expunham.

Curioso perceber que, nesse esforço de integração de recursos multimodais, foi colocada uma televisão no canto do corredor, perto de uma das paredes. Na tela, a exposição era apresentada em forma de documentário. Teria sido bastante enriquecedor, em termos de integração de recursos semióticos, a presença do audiovisual na mostra, não fosse o fato de que, ao fundo, malposicionada e maldimensionada, com um som que não podia competir com o alvoroço cotidiano do corredor de acesso ao Plenário da Casa, a tela permaneceu praticamente invisível. Contudo, o documentário Parlamento e Democracia permanece disponível, por tempo indefinido, na página virtual da Câmara dos Deputados, de onde se pode baixar (fazer download), reproduzir, replicar, ressemiotizar, distribuir, difundir ilimitadamente em ambiente virtual e real.

Indispensável dizer que os recursos semióticos audiovisuais desse documentário não fazem parte desta nossa análise crítica e multimodal, nem mesmo as páginas virtuais em que se ressemiotizam. O nosso corpus restringe-se a textos multimodais expostos na mostra cultural, no corredor da Casa de Leis, aos recursos semióticos do modo escrito e do modo imagético que os integram, pois estes já se prestam, a contento e abundantemente, à perquirição que se realiza neste estudo. 
Figura 4- Televisor utilizado na exposição Parlamento e Democracia

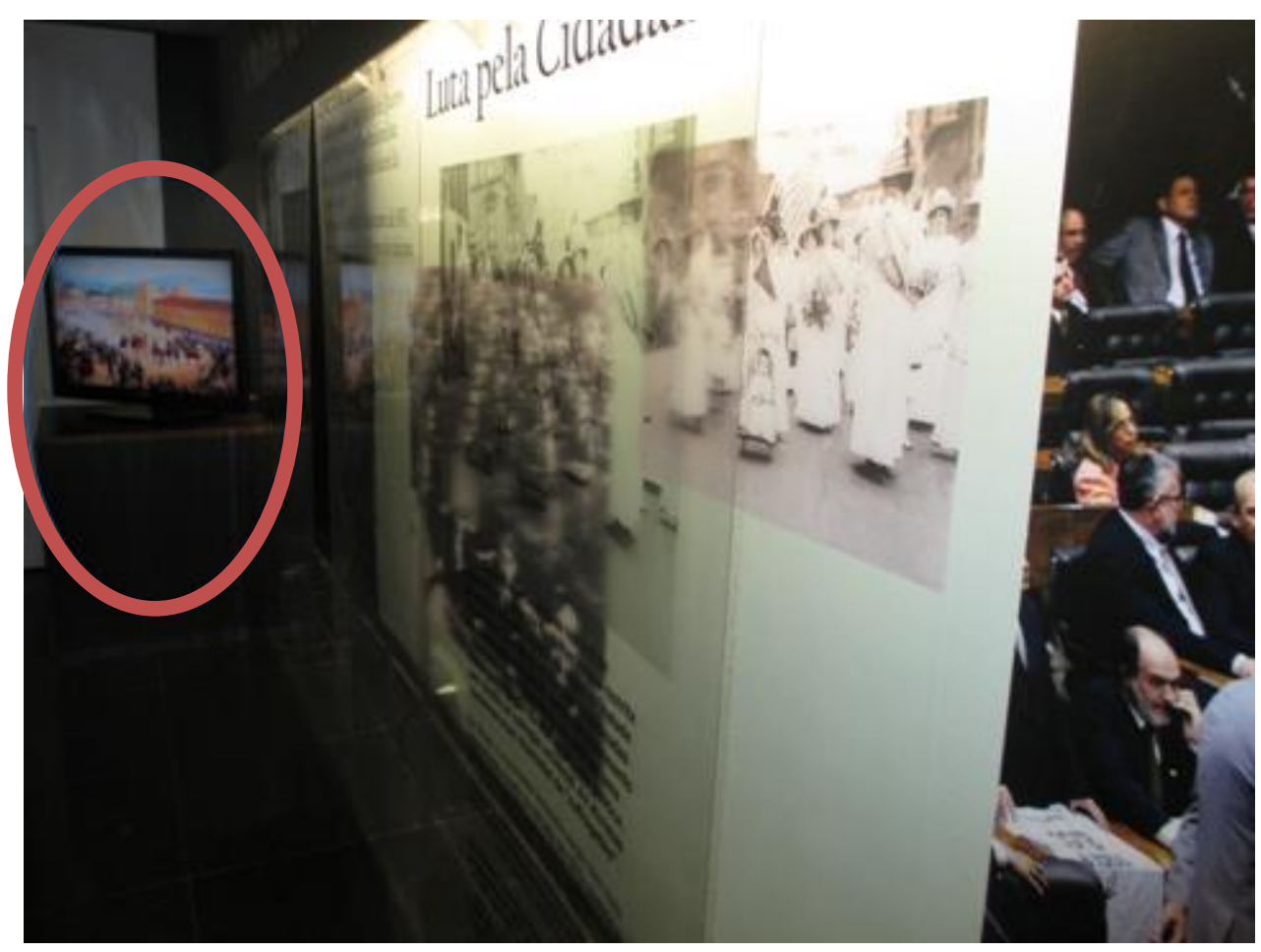

Fonte: Acervo de fotos da autora deste trabalho.

Figura 5- Documentário Parlamento e Democracia, no site da Câmara dos Deputados

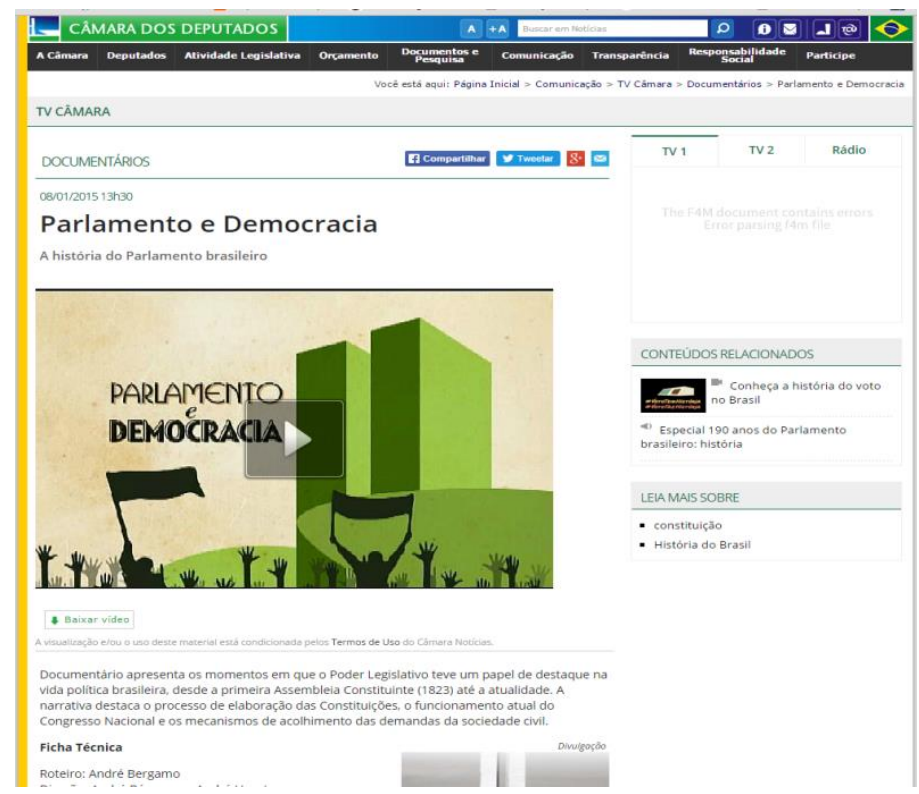

Fonte: Disponível em: <http://www2.camara.leg.br/camaranoticias/tv/materias/DOCUMENTARIOS/480119PARLAMENTO-E-DEMOCRACIA.html>. Acesso em: 26 out. 2015. 
Figura 6 - Exposição Parlamento e Democracia, pelo link TV Câmara

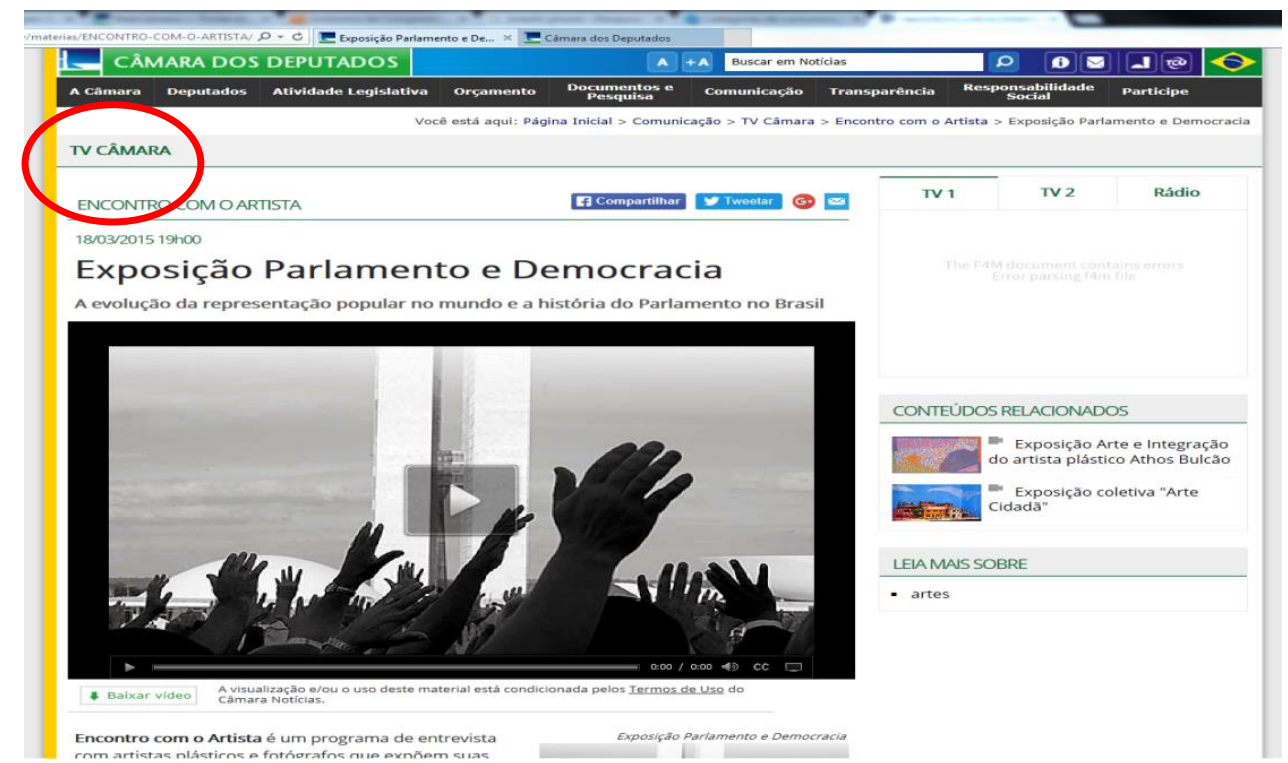

Fonte: Disponível em: <http://www2.camara.leg.br/camaranoticias/tv/materias/483677.html>. Acesso em: 26 out. 2015.

Figura 7 - Exposição Parlamento e Democracia, pelo link Rádio Câmara

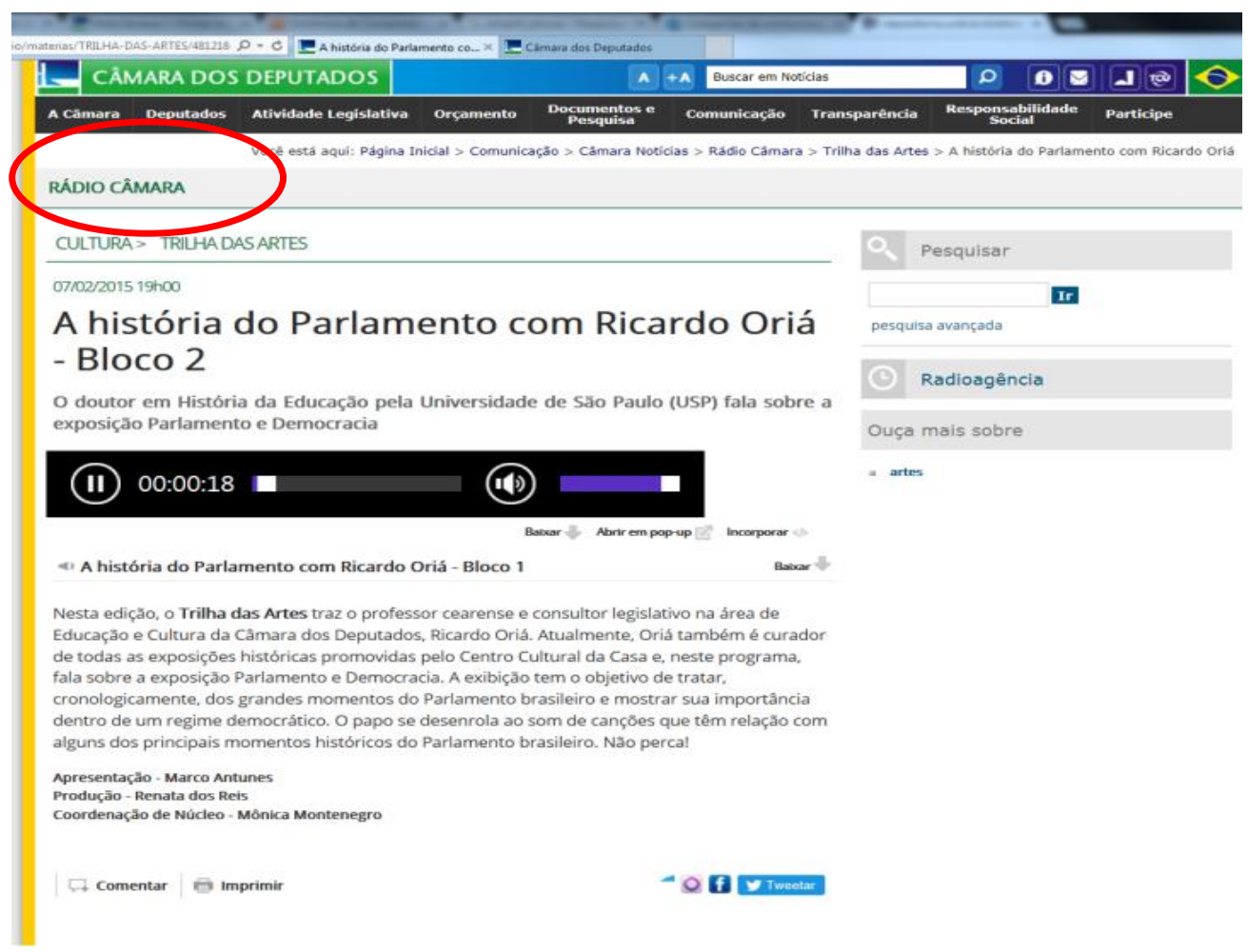

Fonte: Disponível em: <http://www2.camara.leg.br/camaranoticias/radio/materias/TRILHA-DASARTES/481212-A-HISTORIA-DO-PARLAMENTO-COM-RICARDO-ORIA---BLOCO-1.html>. Acesso em: 26 out. 2015. 
Figura 8 - Exposição Parlamento e Democracia, pelo link Cultura na Câmara

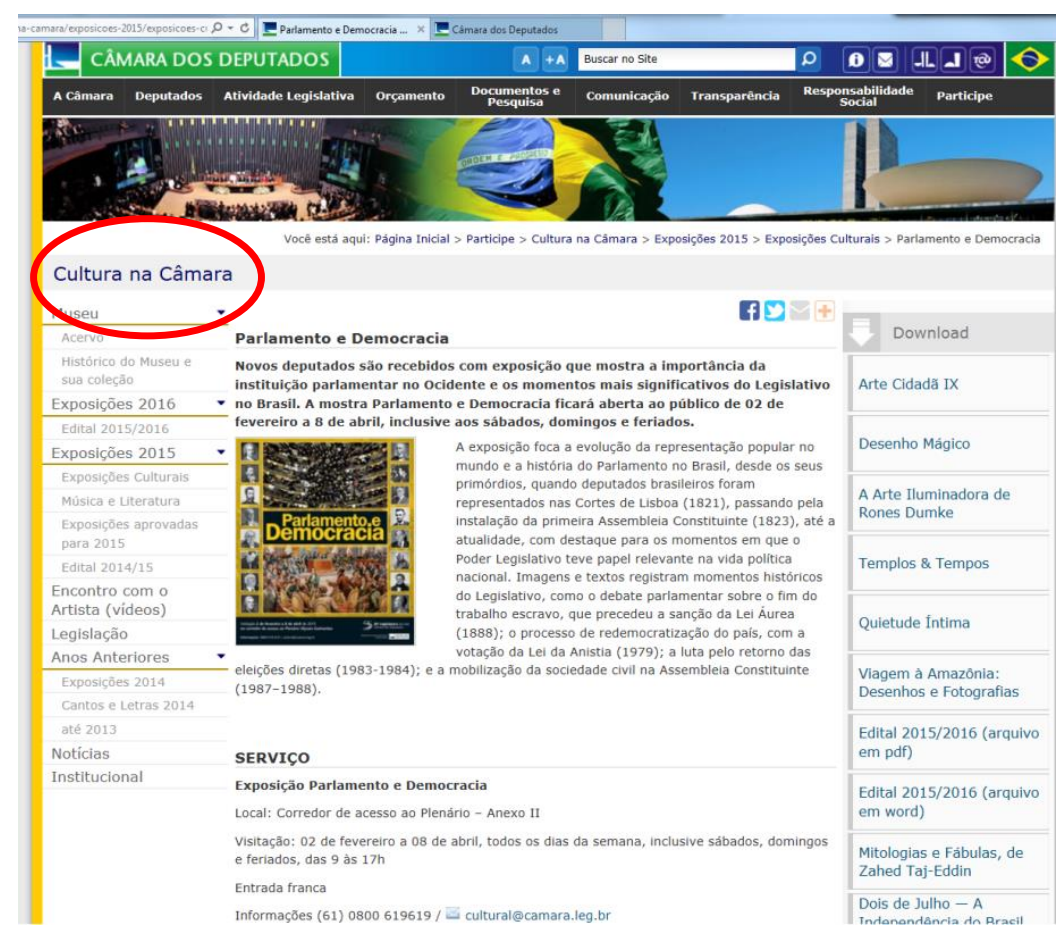

Fonte: Disponível em <http://www2.camara.leg.br/participe/cultura-na-camara/noticias/parlamento-edemocracia> . Acesso em 20 out. 2015.

Consequência concreta da cultura da convergência - entre outras tantas de ordem estrutural, profundas, que transformam práticas sociais - é a produção de conteúdos unificados pelos produtores de mensagens de mídia. Os conteúdos passam a ser elaborados em torno de pauta única e, somente depois, são distribuídos para as diferentes mídias digitais ${ }^{4}$, num momento em que se testemunha a transição entre sistemas analógicos e digitais de produção, publicação, distribuição e consumo desses conteúdos.

Voltamos às lições de Martino (2014, p. 36) para destacar a referência que o autor faz às práticas discursivas de interação, de "compartilhamento de ideias espalhadas entre vários meios de comunicação", da "relação entre pessoas que não se conhecem, mas dividem as mesmas referências". Essa noção de interação e compartilhamento de representações tem sido o mote da comunicação social da Câmara dos Deputados, que busca incessantemente a conexão com o cidadão que representa, não só uma comunhão de significado interacional, mas fundamentalmente ideacional ou representacional.

\footnotetext{
${ }^{4}$ Acerca da produção de conteúdos em plataformas digitais cabem importantes análises sociológicas ligadas às noções de reflexidade e racionalidade (cf. GIDDENS, 1990).
} 
A linguagem dos meios de comunicação, seus códigos e modelos de produção são referências compartilhadas pelos indivíduos e grupos, abrindo espaço para formas de criação. (MARTINO, 2014, p. 36, grifo nosso).

Como prática discursiva, no ambiente virtual e real, os efeitos da convergência estendem-se não só à produção do conteúdo, mas à reprodução, à circulação e à multiplicação dos conteúdos em proporção imensurável. Trata-se de processo comunicativo com um forte poder de realimentação, e com poder político-ideológico indizível, que fez mudar toda a estrutura administrativa dos órgãos de comunicação da Casa do Povo, como se narra mais adiante.

Acerca disso, Martino (Ibid., p. 35) aduz que "a convergência cultural acontece na interação entre indivíduos que, ao compartilharem ideias, valores e mensagens, acrescentam suas próprias contribuições [...], transformando-os e lançando-os de volta nas suas redes". 5 Giddens (1990, p.45) observa este fenômeno sob o enfoque da reflexividade: "A reflexividade da vida social moderna consiste no fato de que as práticas sociais são constantemente examinadas e reformuladas à luz de informação renovada sobre essas próprias práticas, alterando assim seu caráter."

Empoderados e com autonomia, todos os cidadãos tornam-se potenciais produtores de cultura, seja por meio da modificação de conteúdos preexistentes, seja por meio da criação de novos conteúdos. Trata-se da chamada cultura participatória, decorrente da interatividade, que se refere à possibilidade de interferência e interação entre usuários, mas também entre usuários, programas e conteúdos nos sistemas de comunicação digital em rede, de diferentes formas e em níveis diversos (MARTINO, 2014, p. 11).

Não se pode deixar de pensar na relevância que tais mudanças representam para a democracia e para o Parlamento, como Casa representativa do povo.

\footnotetext{
${ }^{5}$ É válido trazer à reflexão o que Heim (1993) apresenta como nova premissa da cultura da convergência quanto à comunicação nas plataformas digitais convergentes e interativas: os indivíduos habituam-se à linguagem dos meios de comunicação. Para o autor, a mente humana adapta-se ao ambiente cognitivo esculpido pelos modos de circulação de dados em cada época. Outrora, fazer o registro definitivo de um texto nos então disponíveis suportes de papel (v.g., via máquinas de escrever que não permitiam correções posteriores) demandavam planejamento, estratégia, tempo e técnica. Hoje a criatividade não encontra óbices: os pensamentos podem instantaneamente ir para a tela digital e, no instante seguinte, serem revistos, alterados, deletados.
} 


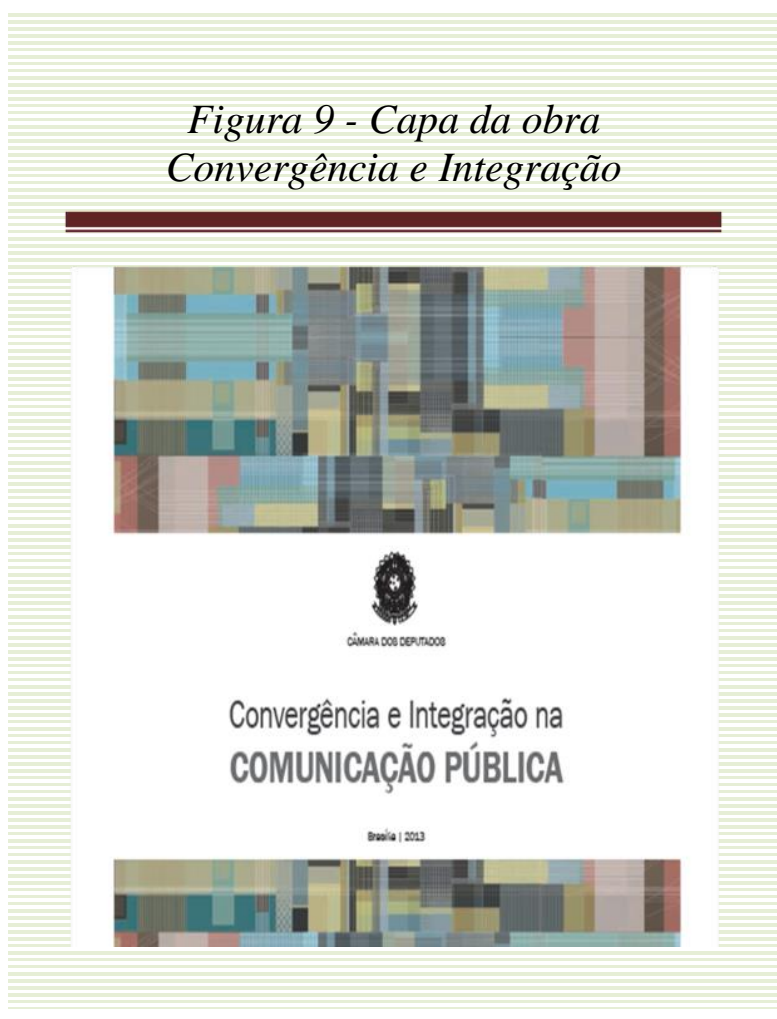

Das elucubrações feitas, verifica-se que a cultura da convergência abarca questões socioculturais (individuais e coletivas), tecnológicas (meios) e semiolinguísticas (códigos, linguagens). E deste fenômeno inescapável da cultura da convergência, que se relaciona substancialmente aos processos comunicacionais e seus meios, não se podem furtar nenhum dos órgãos de comunicação da sociedade contemporânea, nem mesmo os ligados às instituições e organismos estatais, sob pena de sucumbirem à voracidade ideológica da mídia de mercado.

Fonte: BRASIL, 2003.

No Parlamento brasileiro, em particular na Câmara dos Deputados, a chamada cultura da convergência provocou reconfiguração profunda das dinâmicas de produção, circulação e consumo dos conteúdos relativos à difusão da atividade legislativa e dos assuntos de interesse da sociedade em geral, e da forma como se concretizam tais práticas discursivas.

Em 2011, a Secretaria de Comunicação Social da Câmara dos Deputados (Secom) propôs a convergência das mídias da instituição. Todo o processo encontra-se detalhadamente registrado na recente publicação Convergência e integração na comunicação pública (BRASIL, 2013), tendo sido fruto de esforço denodado da Secom e de toda a Casa Legislativa, iniciado ainda no Planejamento Estratégico de 2007.

Do prefácio da obra, um verdadeiro ensaio sobre a cultura da convergência, da ilustre lavra de Alexandre Kieling (Ibid., p. 17), permitimo-nos trasladar este longo trecho, por sua relevância:

[...] O mundo digital que se configura sugere ainda um cenário de convergência das mídias, o que fez Jesús Martin-Barbero (2004) destacar que se vive uma reconfiguração das mediações [...] um fenômeno com repercussão equivalente ao que instituiu as sociedades industriais midiáticas (VERÓN, 2004) observado no século XIX, com o progresso da imprensa escrita e o posterior surgimento do rádio e TV (século $\mathrm{XX}$ ), ou na constituição da sociedade midiatizada (SODRÉ, 2006), com a evolução das mídias eletrônicas incrementadas no pós-guerra. Trata-se de um fenômeno 


\begin{abstract}
que nos convoca a um pensamento de transversalidade no qual comunicação, informação e conhecimento constituem um macroprocesso. [...] Nas ambiências midiáticas (KIELING, 2009) geradas pela convergência de meios (TV, rádio, cinema, internet e telefone), as relações entre produtor e receptor ganham novos estatutos de autonomia e poder, tanto na autoria dos conteúdos quanto na escolha pelas formas de leitura. [...] Ao longo do percurso histórico, cada meio, formado pela tecnologia que lhe deu origem, era regido por lógicas próprias e verticais de produzir, publicar, circular e ler (ouvir, ver, acessar). Com a digitalização, as formas se desintegram. Os textos de jornal, rádio, $\mathrm{TV}$ e web podem circular e ser acessados por meio de diversos aparatos ou por meio de um único aparato. Há um paradigma de horizontalização que começa a se constituir.
\end{abstract}

Os órgãos de mídia da Câmara dos Deputados se posicionaram inarredavelmente favoráveis à mudança na estrutura administrativa da Casa, ciosos de acompanhar os fenômenos inexoráveis da nova formação cultural que já se estabelecia, a era da cultura digital (SANTAELLA, 2003). Os excertos seguintes, trasladados do mesmo documento (BRASIL, 2013, p. 17-18, grifo nosso), mostram o esforço:

[...] um esforço na formação de competências capazes de responder ao desafio que se impõe com esse fenômeno midiático, tensionado pelas lógicas econômicas, políticas, tecnológicas e sociais [...] De fato, segundo alerta Dominique Wolton (1990), a Comunicação não deve ser compreendida apenas a partir das dinâmicas tecnológicas (performance) e das dinâmicas econômicas (um mercado em plena expansão), mas também a partir do seu valor no nosso patrimônio cultural. [...] Nesse sentido, o processo em curso apresenta uma ordem de demandas emergentes aos agentes produtores. A cultura dos processos horizontais impõe a ordem da integração, da transdisciplinaridade. Dar conta desse movimento avassalador pede nova estrutura de realizar, novo modo de fazer. Não há como evitar o movimento na direção de trabalho integrado, no qual jornalistas, radialistas, informáticos, engenheiros, publicitários e designers devem ocupar espaço comum e atuar coordenadamente na produção e na publicação de qualquer tipo de texto informativo. É exatamente essa compreensão que a equipe da Secretaria de Comunicação Social da Câmara dos Deputados teve. Sai de maneira pioneira na direção certa [...], se antecipa no rumo inevitável. [...] Convergência, integração e transdisciplinaridade são componentes de um destino sem fuga.

Assim, a partir de 2013, a Secom passou a contar com apenas dois departamentos centrais: o de Mídias Integradas; e o de Relações Públicas e Divulgação.

Congrega, ainda, o Centro Cultural, a Coordenação de Participação Popular e a Coordenação de Apoio Técnico-Administrativo. Ademais, hoje todos os veículos de 
comunicação da Câmara (TV, rádio, jornais, site), agregados no Departamento de Mídias Integradas, passaram a ser abastecidos por um único serviço de pauta, de produção e de reportagem.

A convergência não significa que um meio novo destrua ou invalide um meio antigo, mas entende que ambos se modificam mutuamente em uma interseção da qual emergem novos significados. (MARTINO, 2014, p. 36).

Consoante a publicação Convergência e integração na comunicação pública (BRASIL, 2013, p. 22), em 2002, nos dias de pico de atividade legislativa, somente $26 \%$ das atividades, em média, eram cobertas pela Secom. Dez anos depois, em 2012, em pleno processo de interseção das mídias, os números mostravam outra realidade:

A Rádio Câmara veiculou mais de 3.500 matérias jornalísticas; a TV Câmara produziu 1.639 reportagens, transmitiu 1.500 horas de reuniões de comissões e quase 1.000 horas de sessões plenárias; e 343 deputados gravaram programas nos estúdios da TV. A Agência Câmara Notícias recebeu mais de 4 milhões de visitas [...] e publicou cerca de 15 mil notícias. A TV Câmara Digital fechou o ano de 2012 com mais 36 milhões de brasileiros vivendo em cidades em que o sinal de TV aberto e gratuito está disponível para a população.

Atualmente, a Rede Legislativa de Rádio e TV, que se tornou uma poderosíssima rede pública nacional, difunde sinal aberto e digital e alcança mais de 50 milhões de pessoas em todo o País. ${ }^{6}$ E com a difusão da TV digital no Brasil, os veículos de comunicação estatais vão ganhar dimensão inédita em termos de acesso ao público cidadão. É significativo notar que o documento Convergência e integração na comunicação pública (Ibid., p. 18, grifos nossos) discorre acerca dos benefícios da difusão da TV digital no Brasil, mas, por óbvio, silencia sobre questões de inserção político-ideológica:

[...] quando acompanhamos [...] a implantação da TV digital no Brasil [...], podemos observar que não se trata apenas da opção pela alta definição (HD) [...] ou mesmo a adoção de uma interatividade local ou de uma interatividade on-line [...]. uma mídia [TV] que abrange mais de 97\% dos domicílios brasileiros, segundo dados da Pnad/IBGE de 2011, apresenta perspectivas

\footnotetext{
6 Segundo informa a página virtual da Câmara dos Deputados, a expansão da cobertura se deve ao compartilhamento de canais e custos com o Senado Federal, as Assembleias Legislativas e Câmaras Municipais, um exemplo de rede pública nacional.
} 
para um novo paradigma das relações sociais, do ingresso de novos atores na economia do audiovisual e das indústrias de conteúdo e criativas e de novas formas de produção e de difusão do conhecimento. A capilaridade da radiodifusão de sons e imagens ainda possibilita um processo de inclusão social por meio da inclusão digital. A familiaridade da população em geral com a televisão constitui-se um facilitador para a alfabetização digital em escala. Se pensarmos no caráter de acesso democrático que o meio possibilita, essa dimensão de importância se alarga ainda mais. E, se pensarmos a partir dos conteúdos informativos, os efeitos desse processo se mostram ainda mais radicais.

Em Fairclough (2006) encontramos a noção de re-scaling, que seria o replanejamento das relações de escalas de atividade e interação entre o local, o nacional e o internacional pelas instituições, por parte de entidades espaciais específicas, como os estados-nação. No que diz respeito ao Parlamento brasileiro, o redimensionamento dos canais de comunicação social é patente. No âmbito nacional, a mídia parlamentar lança programas para a ampliação expressiva de sua abrangência midiática, principalmente para rádio e TV. O Ato da Mesa $\mathrm{n}^{\circ}$ 52, de 17 de outubro de $2012^{7}$, cria a Rede Legislativa de TV Digital e a Rede Legislativa de Rádio da Câmara dos Deputados, nos seguintes termos:

Art. $1^{\circ}$ Ficam criadas na Câmara dos Deputados, com operação em todo o território nacional, a Rede Legislativa de TV Digital e a Rede Legislativa de Rádio.

Art. $2^{\circ}$ As Redes de que trata este Ato da Mesa têm como objetivo a universalização, progressivamente, do acesso dos brasileiros aos sinais das emissoras da TV Câmara e da Rádio Câmara [...]

Art. $3^{\circ}$ A operação da Rede Legislativa de TV Digital e da Rede Legislativa de Rádio, em todo o território nacional, ficará a cargo da Secretaria de Comunicação Social da Câmara dos Deputados.

Art. $4^{\circ}$ Para fins do disposto neste Ato da Mesa, considera-se:

I - universalização: possibilidade de acesso de qualquer pessoa ou instituição aos conteúdos da TV Câmara e da Rádio Câmara por meio de radiofusão, aberta e gratuita, independentemente de sua localização e condição socioeconômica $[\ldots]$

O quadro a seguir mostra, de forma resumida, a partir da data de criação de cada veículo de comunicação, a evolução do sistema de comunicação da Câmara dos Deputados até os dias atuais. ${ }^{8}$

\footnotetext{
${ }^{7}$ Disponível em: <http://www2.camara.leg.br/comunicacao/rede-legislativa-radio-tv/ato-da-mesa〉. Acesso em 26 out 2015.

${ }^{8}$ O quadro foi elaborado por esta Articulista, com base em dados obtidos na publicação Convergência e integração na comunicação pública (BRASIL, 2013).
} 
Quadro 1 - Evolução do Sistema de Comunicação da Câmara dos Deputados

\begin{tabular}{|c|c|c|c|}
\hline \multicolumn{4}{|c|}{$\begin{array}{l}\text { Evolução do Sistema de Comunicação da Câmara dos Deputados } \\
\text { Dos Anos } 60 \text { ao ano } 2014\end{array}$} \\
\hline $\begin{array}{l}\text { Data de criação } \\
\text { do veículo }\end{array}$ & Formato do Veículo & Título & Órgão Editor \\
\hline Final dos anos 60 & $\begin{array}{ll}\text { boletim } & \text { informativo } \\
\text { impresso } & \end{array}$ & Câmara é Notícia & Câmara dos Deputados \\
\hline 1963 & rádio & Voz do Brasil & $\begin{array}{l}\text { Câmara dos Deputados } \\
\text { outros órgãos } \\
\text { dos Poderes da República }\end{array}$ \\
\hline Década de 70 & $\begin{array}{l}\text { boletim informativo } \\
\text { impresso }\end{array}$ & Informação & Câmara dos Deputados \\
\hline Década de 80 & $\begin{array}{l}\text { boletim informativo } \\
\text { impresso }\end{array}$ & Câmara Informa & Câmara dos Deputados \\
\hline $\begin{array}{l}\text { 1987-1988 } \\
\text { (Assembleia } \\
\text { Nacional } \\
\text { Constituinte) }\end{array}$ & jornal impresso & $\begin{array}{l}\text { Jornal } \quad d a \\
\text { Constituinte }\end{array}$ & $\begin{array}{l}\text { Câmara dos Deputados } \\
\text { e Senado Federal }\end{array}$ \\
\hline 1990-1998 & jornal impresso & Hoje na Câmara & Câmara dos Deputados \\
\hline 1998 & jornal impresso & Jornal da Câmara & Câmara dos Deputados \\
\hline 1998 & $\mathrm{TV}$ & TV Câmara ${ }^{10}$ & Câmara dos Deputados \\
\hline 1998 & rádio & Rádio Câmara & Câmara dos Deputados \\
\hline 2000 & site & $\begin{array}{l}\text { Agência Câmara de } \\
\text { Notícias }\end{array}$ & Câmara dos Deputados \\
\hline
\end{tabular}

Fonte: Quadro elaborado pela autora, com base no documento BRASIL, 2013.

Vê-se que somente em 1998 as mídias radiofônicas e televisivas passaram a fazer parte do sistema de comunicação da Casa Legislativa, sete anos após o surgimento da World Wide Web, que ocorreu em 1991. Mas a página virtual, a Agência Câmara de Notícias, que, além dos conteúdos próprios, congrega o de todas as outras mídias, começou suas atividades em 2000, ou seja, há aproximadamente quinze anos, na mesma época em que o mundo conheceu a dinâmica Web 2.0, que possibilitou interação e maior compartilhamento de conteúdo entre os usuários da rede, inclusive o surgimento das redes sociais.

Entre todas as consequências — no âmbito parlamentar — desses fenômenos que estamos descortinando, há uma que merece particular menção: em 2015, de forma inédita, a direção da Secretaria de Comunicação Social da Câmara dos Deputados passou a ser ocupada

\footnotetext{
${ }^{9}$ O registro Convergência e integração na comunicação pública, fonte principal dos dados organizados no quadro, refere-se ao jornal impresso como "boletim informativo", até a década de 80. É preciso esclarecer que, muito embora chamemos de "jornal”, as edições ainda hoje não são diárias. Somente a partir de 2011, o "boletim informativo" passou a ser impresso e distribuído também nas segundas-feiras, e distribuído aos turistas e visitantes do Palácio do Congresso durante os fins de semana.

${ }^{10}$ A Lei no 8.977, de 6 de janeiro de 1995, conhecida como a Lei do Cabo, previu a inclusão de canais de acesso público e estabeleceu reserva de canais de TV a cabo para informações de interesse público, como canais comunitários, universitários e legislativos.
} 
por Deputado, e não mais por servidor efetivo, concursado. $O$ fato, bastante questionado na comunidade parlamentar e fora dela, certamente denuncia o aumento do prestígio e da importância da comunicação política institucional, mormente no que concerne à manutenção das estruturas sociais de dominação.

Não se pode deixar de assinalar que, para alguns Deputados, o que está em jogo é a própria democracia. O Deputado Hildo Rocha, membro do Partido do Movimento Democrático Brasileiro (PMDB) do Maranhão, assim se manifestou: "No momento em que se coloca um deputado, seja ele quem for, para tomar conta do serviço que mais avançou nesta Câmara, nós vamos partidarizar”. Ombreou-se-lhe o Deputado Chico Alencar, do Partido Solidariedade (PSOL) do Rio de Janeiro: "Pode desqualificar a comunicação desta Casa, espaço a ser preservado. O nosso temor é que comecemos a partidarizar, selecionar matérias [...], e isso é o fim da democracia." ${ }^{11}$

Enfim, como parte irredutível da vida social (FAIRCLOUGH, 2003), a linguagem conecta-se aos elementos sociais, a eventos e práticas, e o faz de forma dialética, modificando-os e sendo por estes modificada. Os efeitos da convergência cultural, marco na era da cultura digital, efeitos que se relacionam às novas práticas sociais e até então inéditas formas de agir (FAIRCLOUGH, 2003), fazem-se sentir, inexoravelmente, na formação e transformação dos gêneros discursivos, foco deste estudo. Certamente também foram considerados por Kress e van Leeuwen (1996), quando da elaboração do Princípio da Integração dos Recursos Semióticos, coração da análise formal-discursiva neste trabalho.

Nesta seção, buscamos compreender o fenômeno social e discursivo nominado cultura da convergência, seguindo seus rastros e mapeando o impacto e os efeitos profundos que vem provocando nas práticas discursivas na Câmara dos Deputados do Brasil.

A seguir, na última seção deste primeiro capítulo, ainda como parte da contextualização sócio-histórica e situacional, fazemos brevíssima consideração acerca da relação simbiótica entre Parlamento e Democracia, título da mostra cultural que analisamos.

\footnotetext{
${ }^{11}$ Fonte: Anais da Câmara dos Deputados.
} 


\title{
1.2 PARLAMENTO E DEMOCRACIA
}

Parlamento e democracia conformam, entre si, a tessitura de relação semântica que poderia classificar-se validamente como metonímica (FAIRCLOUGH, 2003). E isto se dá porque a história do Parlamento constrói-se paralelamente à da democracia, de tal sorte que os dilemas da democracia moderna representam, especialmente para o Parlamento brasileiro, verdadeiro problema constitutivo.

Órgão do Poder Legislativo da República Federativa do Brasil, a Câmara dos Deputados incorpora a democracia representativa e, por meio de seus órgãos de comunicação, busca a proximidade com o cidadão que representa e a opinião pública, construída na chamada esfera pública. Habermas (1984) entende a esfera pública como espaço abstrato de discussão e deliberação acerca de assuntos diversos de interesse público, relevantes e pertinentes ao interesse do cidadão em Estado regulado pelo Direito, ou seja, assunto de cunho político. Nesse sentido, a esfera pública guarda relação direta com a democracia e as instituições que a perpetuam.

Mas nunca foi ou será ordinária a tarefa de sustentar a democracia, um dos pilares republicanos. A história narra regimes de exceção desde a Primeira República do Brasil. Nesse sentido, alertam as palavras do então Deputado Tancredo Neves (falecido em 1985), proferidas no Congresso Nacional, na sessão do dia 18 de setembro de 1951, e registrada no Diário da Câmara:

\begin{abstract}
A democracia é, pois, um ideal em permanente dinamismo, que se transforma e aperfeiçôa num incessante desenvolvimento que não lhe permite conquistas pacíficas e definitivas. Cada posição alcançada, reclama uma constante renovação de esforços, de trabalhos e de sacrifícios. ${ }^{12}$
\end{abstract}

Esse esforço se recrudesce nestes dias de sociedades conectadas em rede e cibercultura. Impende notar que, para a democracia brasileira, como de resto para qualquer democracia do mundo, a repercussão de expressões como "crise de representativade" e "crise de legitimidade" se agigantam nas redes digitais, e são fonte de importantes preocupações, especialmente neste início deste século XXI, que testemunha a expansão das novas democracias digitais. Nestas, os debates entre população e governo ocorrem primordialmente

\footnotetext{
${ }^{12}$ Publicado no Diário da Câmara dos Deputados de 19/09/1951, p. 8.273-8.274.
} 
por meio da internete.

Esta apreensão não deixa de ecoar fortemente na Casa de Leis brasileira, colocando-se como seu maior desafio. Este repto, explicita-o o Presidente eleito para o primeiro biênio da $55^{\mathrm{a}}$ Legislatura, iniciada em $1^{\mathrm{o}}$ de fevereiro de 2015, Deputado Eduardo Cunha:

Nós estamos numa discussão de recuperação do orgulho do Parlamento. [...] Nós não podemos deixar de considerar que muitos têm vergonha de ir às ruas e dizer que são Deputados. [...] Nós precisamos nos encontrar com a sociedade e a sua pauta. [...] Nós temos que devolver à Câmara a dimensão que ela deveria ter e que o Brasil merece que a Câmara tenha. (Palmas.)

Para Manuel Castells (1999), os sistemas políticos passam, de fato, por uma "crise de legitimidade, com dependência total da cobertura da mídia e de liderança personalizada, e cada mais isolados dos cidadãos”. É de elevado quilate, portanto, o papel dos órgãos de comunicação social da Câmara dos Deputados no esteio da condição democrática e fortalecimento do Parlamento. As metas, objetivos e estratégias que avocam para si, demonstram a grandeza da tarefa:

[Metas] [...] contribuir para o desenvolvimento da cidadania; contribuir para o fortalecimento institucional da Câmara; e ser referência em comunicação pública.

[Objetivos] [...] massificar a comunicação com o cidadão, ampliar a visibilidade do trabalho dos deputados; aperfeiçoar a interação com os servidores e o atendimento às áreas da Câmara; e aperfeiçoar a comunicação com a sociedade civil organizada e com a imprensa.

[Estratégias] [...] gerar informações em linguagem adequada, de forma isenta, apartidária e confiável; intensificar a comunicação dos trabalhos e resultados positivos da Câmara, sem prejuízo da cobertura jornalística; e ampliar e aperfeiçoar canais de distribuição e de interatividade. (BRASIL, 2013, p. 23).

A consecução das metas da Secretaria de Comunicação Social da Câmara dos Deputados torna-se ainda mais complexa diante dos já apontados fenômenos da multimodalidade e da integração e convergência das mídias. Estudar criticamente tais alterações estruturais e mudanças discursivas — por meio da análise de textos multimodais produzidos pela mídia parlamentar — pode e deve levar à compreensão maior das conformações havidas nos contextos culturais que moldam o discurso político e midiático e a comunicação pública estatal, bem assim das conformacões políticas e sociais engendradas 
pelas práticas discursivas instanciadas no Parlamento brasileiro, mas recontextualizadas e ressemiotizadas (IEDEMA, 2003) nos mais diversos ambientes de interação social.

Neste primeiro capítulo, situamos o objeto de estudo nos contextos sócio-histórico e situacional, colocando em relevo fenômenos como multimodalidade e convergência cutural, que emolduram o cenário e o momento em que a Câmara dos Deputados apresentou aos Parlamentares e ao público em geral a exposição histórica Parlamento e Democracia. Discorremos, ainda, sobre a relação simbiótica entre parlamento e democracia. No próximo capítulo, apresentamos as fundamentações teóricas e metodológicas que esteiam este estudo crítico. 


\section{CAPÍTULO 2}

\section{ESTEIOS TEÓRICO-METODOLÓGICOS}

\subsection{SOBRE O GÊNERO DO DISCURSO}

Neste ponto do trabalho, analisam-se as bases teóricas e metodológicas para o estudo do gênero discursivo dos textos que compõem o corpus de análise, estudo que evoca as noções de dialogismo, interdiscursividade e intertextualidade, hibridismo de gênero, recontextualização, noções bastante caras ao trabalho analítico a que se propõe esta dissertação. Nesta, busca-se compreender como o poder opera no discurso. Nos termos de Teun van Dijk (2008, p. 85), "seja em sua forma direta, seja em sua forma indireta, o poder é tanto exercido quanto reproduzido no e pelo discurso".

Rajagopalan (2001, p. 189) enfatiza: "Fora do mundo idealizado por alguns teóricos, os gêneros híbridos são apontados como a regra e não mais uma exceção“. O desafio maior e central deste estudo consiste na delimitação e definição do gênero discursivo dos textos sob exame, que tangenciam as esferas política, midiática, institucional pública, cultural e histórica. Trata-se de desafio expressivo, pois inúmeros são os debates acerca dos gêneros do discurso, e todos perpassam questões afetas à própria definição de linguagem e do uso da língua nos mais diferentes e complexos campos da atividade humana, correlacionando o primeiro aos últimos (MEURER et al, 2005, p. 8).

Não obstante haja diferentes abordagens sobre o gênero discursivo e textual - a teoria de gêneros do discurso centraliza-se no estudo das situações de produção dos enunciados ou textos em seus aspectos sócio-históricos, enquanto a teoria de gêneros textuais focaliza a descrição da materialidade textual —, posto que se possam distinguir inúmeras teorias e métodos, os trabalhos que se preocupam com o caráter social do discurso (abordagens sociossemióticas, sociorretóricas e sociodiscursivas) convergem e, polifônicos, invariavelmente travam diálogo com os estudos precursores do Círculo de Bakhtin ${ }^{\mathbf{1 3}}$, cujos

${ }^{13}$ Compuseram o chamado Círculo de Bakhtin, entre 1919 a 1974, além do próprio pesquisador russo, os intelectuais e pesquisadores Voloshinov e Medvedev. 
fundamentos são a concepção sócio-histórica e ideológica da linguagem; o caráter sóciohistórico, ideológico e semiótico da consciência; e a realidade dialógica da linguagem e da consciência (RODRIGUES, 2005, p. 154) ${ }^{\mathbf{1 4}}$.

Por essa razão, iniciamos nosso percurso com uma visita acurada às bases teóricometodológicas propostas por Bakhtin para a análise dos gêneros do discurso. Em seguida, focamos o conceito de gênero de Fairclough e Kress, apontando as confluências e ressaltando as noções que nos são caras a este estudo, inclusive no que diz respeito ao método e às categorias de análise.

\subsubsection{O gênero do discurso segundo Bakhtin}

Bakhtin (1992 [1929], p. 279), que toma o enunciado como unidade da comunicação discursiva e, portanto, unidade de análise da comunicação verbal, considera a estabilidade como atributo intrínseco aos gêneros discursivos, o que se faz notar na própria definiçãa da expressão: "tipos relativamente estáveis de enunciados" ou "formas relativamente estáveis e normativas de enunciados" - uma vez constituídos, de forma dialética, os gêneros exercem efeito de norma (coerção) sobre as interações verbais na comunicação social.

Gêneros do discurso seriam, portanto, formas típicas de enunciados.

Assimilamos as formas da língua somente nas formas das enunciações e justamente com essas formas. As formas da língua e as formas típicas dos enunciados, isto é, os gêneros do discurso, chegam à nossa experiência e à nossa consciência em conjunto e estreitamente vinculadas. (BAKHTIN, 2003 [1952-1953], p. 282-283, grifo nosso).

Para aquele linguista russo, os gêneros do discurso nos chegam como a nós chega a própria língua materna, "que dominamos com facilidade antes mesmo que lhe estudemos a gramática" (Ibid., p. 263). Entende, portanto, que todas as pessoas possuem e dominam um vasto repertório de gêneros discursivos, “às vezes padronizados e estereotipados, às vezes

\footnotetext{
${ }^{14}$ Vale apontar o alerta de Faraco (2001, p. 28) quanto à predicação de Bakhtin como precursor dos estudos ocidentais sobre linguagem e gênero, pois, não obstante a anterioridade do trabalho de Bakhtin (entre 1919 e 1974) e a coincidência dos temas estudados, o contato entre estes estudos e os desenvolvidos no Ocidente somente ocorreu tardiamente, a partir de 1960, por meio de Kristeva, e teriam se prestado mais como problematizador dos estudos já em andamento do que base destes.
} 
mais maleáveis, mais plásticos e mais criativos", aos quais moldam a fala com desenvoltura, segurança e destreza.

Assim, a definição bakhtiniana de gêneros discursivos — "tipos relativamente estáveis de enunciados" - busca mitigar uma noção rígida e fixa de padrões e estereótipos para a identificação e delineação dos gêneros discursivos, ao tempo em que correlaciona os "tipos" de enunciados às diferentes atividades humanas.

Quanto ao emprego da expressão "tipos de enunciados", indispensável assinalar que o gênero não se define por suas propriedades formais, mas por sua correlação com uma situação social de interação. Rodrigues (2015, p. 164) busca explicitar o emprego do termo "tipo" na definição de gênero em Bakhtin:

\begin{abstract}
Analisando o desenvolvimento da noção de gênero em Bakhtin, pode-se dizer que sua noção de gênero como tipo de enunciado não é a de sequências textuais, nem o resultado de uma taxonomia ou princípio de classificação científica, mas uma tipificação social dos enunciados que apresentam certos traços (regularidades) comuns, que se constituíram historicamente nas atividades humanas, em uma situação de interação relativamente estável, e que é reconhecida pelos falantes.
\end{abstract}

Assim, não obstante os gêneros mais estabilizados possam ser identificados por sua dimensão linguístico-textual (propriedades formais), o que lhes caracteriza essencialmente é sua relação com a situação social de interação, que ocorre dentro de determinada esfera discursiva, considerada a sua finalidade e a sua concepção própria de autor e destinatário.

Neste ponto, abre-se um parêntese para dizer que a definição bakhtiniana de gênero permite que se façam, pelo menos, duas considerações, úteis ao estudo do nosso objeto de análise, que se adjetiva, a um só tempo, como político-institucional, midiático e cultural.

Como primeira consideração, aduz-se que fenômenos socioculturais tornam os gêneros passíveis de inovação (sem que se lhes venha a escoimar o caráter ontologicamente regular), à medida que evoluam as práticas sociais e venham a surgir e (relativamente) estabilizarem-se novas situações sociais de interação.

A segunda consideração é que há importante inter-relação entre os gêneros primários e secundários, conforme assinala o estudo do gênero bakhtiniano apresentado por Rodrigues (2005, p. 169): os gêneros primários, afetos primordialmente à espontaneidade da interação verbal, como o diálogo cotidiano, "constituem-se na comunicação discursiva imediata no 
âmbito da ideologia do cotidiano"; os gêneros secundários, relacionados principalmente aos textos escritos e a situações comunicativas mais complexas, como o discurso científico, “surgem nas condições da comunicação cultural mais 'complexa', no âmbito das ideologias formalizadas e especializadas, que, uma vez constituídas, 'medeiam' as interações sociais: na esfera artística, científica, religiosa, jornalística, escolar, etc.”

Vale registrar também que, para Bakhtin, gêneros secundários podem, em seu processo de formação, absorver e reelaborar gêneros primários (como forma de representação do diálogo cotidiano), assim como gêneros primários podem intercalar-se em gêneros secundários (como, por exemplo, uma carta pessoal inserida no contexto de um romance). Ademais, não exerce a escrita um papel diferenciador dos gêneros, pois pode haver textos escritos caracterizados como gênero secundário (v.g., um diário pessoal) e textos orais caracterizados como gênero primário (v.g., uma palestra científica). O que os distingue é a situação de interação e o enquadramento desta em determinada esfera discursiva, além da finalidade e da concepção de autor e destinatário da comunicação social.

Estas considerações se mostram relevantes para o exame das mudanças discursivas havidas e em curso no âmbito da produção comunicativa levada a cabo pela mídia parlamentar: a uma, porque envolvem questões relativas ao dinamismo, à inovação, ao surgimento de novos gêneros, assim como ao hibridismo de gêneros discursivos (gêneros que nascem da combinação de outros gêneros); a duas, porque o fenômeno da aproximação dos gêneros primários e secundários guarda relação intrínseca com o fenômeno da multimodalidade na comunicação social e evoca a discussão de temas (explicitados mais adiante) relevantes ao estudo linguístico crítico, como a conversacionalização, a informalização e a democratização do discurso, a par das tendências de comodificação e tecnologização das práticas discursivas, apontadas por Fairclough (2001, 2003); a três, porque em todas essas questões relativas ao estudo do gênero está imbricado o emprego de estratégias discursivas de operacionalização ideológica e política.

Sendo indissociáveis linguagem e sociedade, as várias esferas da atividade humana compreendem-se como domínios ideológicos (político, jurídico, religioso, jornalístico, educacional) que dialogam entre si e produzem, cada uma dessas esferas, formas relativamente estáveis de enunciados, os chamados gêneros discursivos. Eis o que afirma Bakhtin (2003, p. 290) acerca da relação entre esferas da atividade humana e a utilização da língua: 
Todas as esferas da comunicação humana, por mais variadas que sejam, estão sempre relacionadas com a utilização da língua. Não é de surpreender que o caráter e os modos dessa utilização sejam tão variados como as próprias esferas da atividade humana [...]. A utilização da língua efetua-se em forma de enunciados (orais e escritos), concretos e únicos, que emanam dos integrantes duma ou doutra esfera da atividade humana. $\mathrm{O}$ enunciado reflete as condições específicas e as finalidades de cada uma dessas esferas (...) cada esfera de utilização da língua elabora seus tipos relativamente estáveis de enunciados, sendo isso que denominamos gêneros do discurso.

Impende assinalar que, na construção teórica de Bakhtin (2003, p. 302), os estudos sobre os gêneros do discurso revelam-se fulcrais para o entendimento da própria comunicação verbal - por extensão, lato sensu, da comunicação oral e escrita -, consoante propugna o autor:

Se não existissem os gêneros do discurso e se não os dominássemos, se tivéssemos que criá-los pela primeira vez no processo da fala, se tivéssemos de construir cada um de nossos enunciados, a comunicação verbal seria quase impossível.

Com efeito, não se pode compreender a definição de gênero do discurso para o Círculo de Bakhtin sem que se entenda o conceito que elabora para o termo "enunciado". Ao situar o enunciado como unidade da comunicação discursiva, Bakhtin (1997 [1929], p. 181) sintetiza a noção de linguística e metalinguística (ou translinguística) nos termos "língua sistema" e "língua discurso". Assim, propugna que o texto, multiplanar, pode ser estudado com base naqueles dois planos teóricos e, por conseguinte, ser compreendido como "texto sistema" e "texto enunciado". 
Figura 10- Plano de Análise do Texto, segundo Bakhtin (1997)

\section{PLANOS DE ANÁLISE DO TEXTO (BAKHTIN, 1997)}
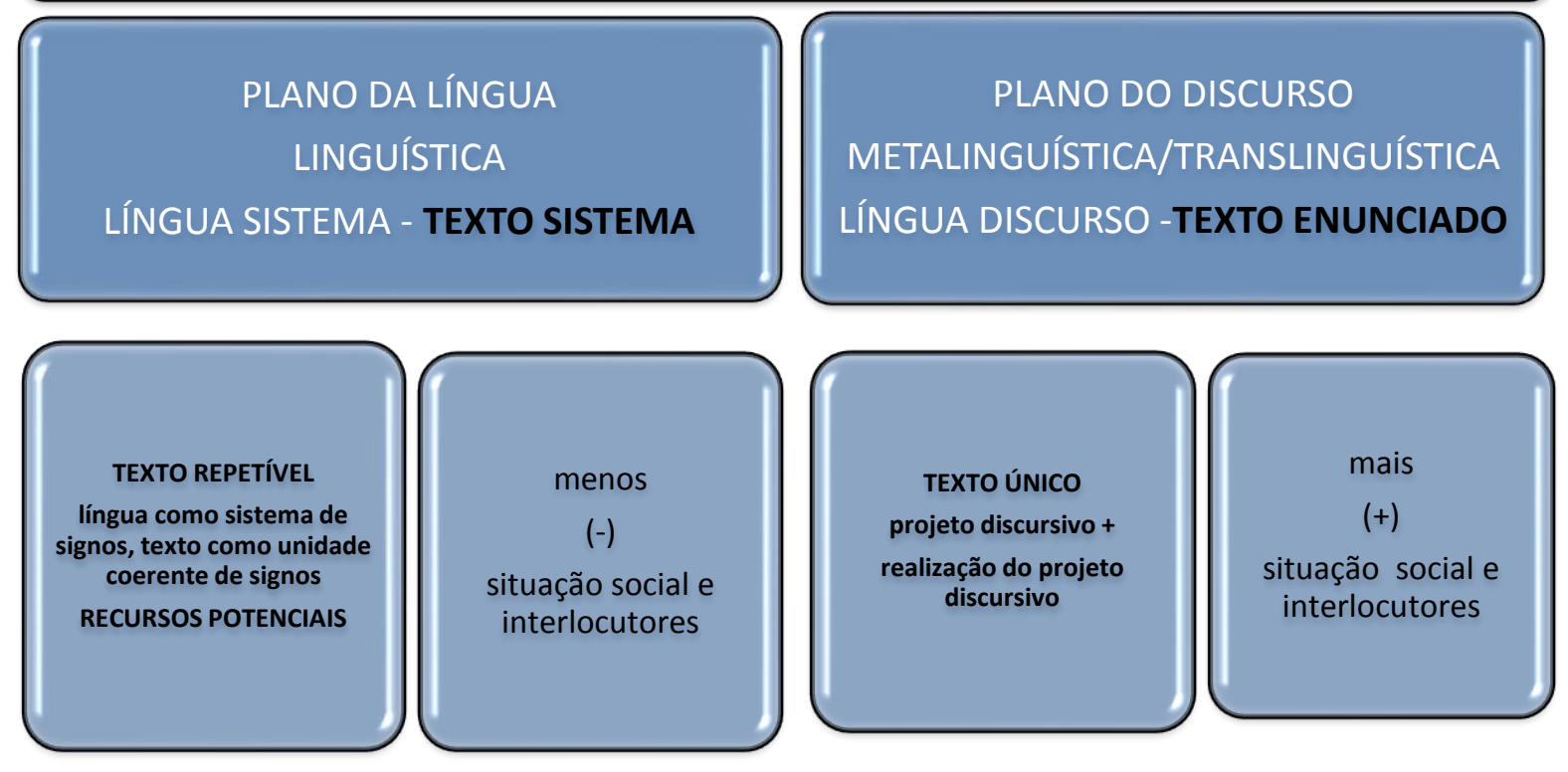

Fonte: Elaborado pela autora, com base em dados de Rodrigues (2005, p. 158-159).

No plano da língua - esta, um sistema de signos —, o texto é uma unidade coerente de signos, com elementos repetíveis e reproduzíveis. Por estar o "texto sistema" no domínio do repetível, é material e meio, com recursos semânticos potenciais. No plano do discurso, o texto se manifesta na situação social, em determinada esfera, e em relação a outros textos (relação dialógica). O "texto enunciado" é único, irrepetível, determinado por seu projeto discursivo (o seu autor e o seu querer dizer) e a realização desse projeto, conforme as coerções/limitações/condições de produção dadas pela situação social de interação, pelos recursos da língua, pelo gênero, etc.

As seguintes características do "texto enunciado" o distinguem do "texto sistema" (RODRIGUES, 2005, p. 161): i) alternância dos sujeitos do discurso, como fronteiras que delimitam cada enunciado. Marca-se o término do enunciado pelo dixi conclusivo do falante (que disse o que pretendia dizer, conforme seu projeto discursivo), para que outro inicie o 
enunciado seguinte, a compreensão ativa, a postura de resposta, que pode ser até mesmo silenciosa, verbal ou não verbal, imediata ou retardada; ii) expressividade, como instância de expressão da valoração do autor frente ao objeto do seu discurso, aos participantes da comunicação discursiva, a outros enunciados já ditos e pré-figurados (antecipação da reação/resposta do outro). A neutralidade não caracteriza o "texto enunciado", mas somente o "texto sistema"; iii) conclusividade, como manifestação da alternância dos sujeitos discursivos, em que a postura de resposta do interlocutor leva em consideração o tratamento exaustivo do objeto e do sentido, a intencionalidade do falante (projeto discursivo) e os gêneros do discurso.

Consoante Bakhtin (1997 [1929], p. 181), “[...] a linguística e a metalinguística estudam um mesmo fenômeno concreto, muito complexo e multifacético, o discurso, mas o estudam sob diferentes aspectos e diferentes ângulos de visão". Estas duas dimensões — a interseção entre o estritamente verbal e o social — são constitutivas do gênero.

Na construção do sentido de gênero do discurso, diz Bakhtin (1992):

\begin{abstract}
O enunciado reflete as condições específicas e as finalidades de cada uma dessas esferas, não só por seu conteúdo (temático) e por seu estilo verbal, ou seja, pela seleção operada nos recursos da língua - recursos lexicais, fraseológicos e gramaticais -, mas também, e sobretudo, por sua construção composicional. Esses três elementos (conteúdo temático, estilo e construção composicional) fundem-se indissoluvelmente no todo do enunciado, e todos eles são marcados pela especificidade de uma esfera da comunicação. Qualquer enunciado considerado isoladamente é, claro, individual, mas cada esfera de utilização da língua elabora seus tipos relativamente estáveis de enunciados, sendo isso que denominamos gêneros do discurso.
\end{abstract}

Para Bakhtin, portanto, o "texto enunciado" — assim como o gênero do discurso — é um compósito de tema/sentido (objeto discursivo e finalidade discursiva/outros enunciados), estilo (uso típico dos recursos lexicais, fraseológicos e gramaticais da língua) e composição (procedimentos composicionais para a organização, disposição e acabamento da totalidade discursiva e da relação dos participantes da comunicação discursiva), conforme esclarece Rodrigues (2005, p. 167). Constitui-se da sua própria dimensão extraverbal (que não o envolve simplesmente, antes o compõe), formada por três "horizontes": o espacial e temporal (contexto histórico), o temático (objeto, aquilo de que se fala, a finalidade do enunciado) e o axiológico (a atitude valorativa do falante em relação ao objeto, a outros enunciados, aos 
interlocutores).

Rojo (2015, p. 196, grifo do original) melhor explicita as três dimensões essenciais e indissociáveis dos gêneros do discurso, segundo Bakhtin:

a) os temas - conteúdos ideologicamente conformados - que se tornam comunicáveis (dizíveis) através do gênero;

b) os elementos das estruturas comunicativas e semióticas compartilhadas pelos textos pertencentes ao gênero (forma composicional);

c) as configurações específicas das unidades de linguagem, traços da posição enunciativa do locutor e da forma composicional do gênero (marcas linguísticas ou estilo).

Rojo (2005, p. 196, itálico do original) esclarece que as três dimensões dos gêneros discursivos são determinadas pelos "parâmetros da situação de produção dos enunciados e sobretudo, para Bakhtin/Voloshinov (1929), pela apreciação valorativa do locutor a respeito do(s) tema(s) e do(s) intercolutor(es) de seu discurso".

Esta situação social mais imediata tem como elementos essenciais os "parceiros da interlocução", cujas relações se estruturam e se determinam por esferas comunicativas, que são formas de organização e distribuição dos lugares sociais nas diferentes instituições e situações sociais de produção dos discursos. Esta noção de parceiros da interlocução vai repercutir no construto teórico que Gunther Kress apresenta para o estudo do gênero, que se realiza, segundo o autor, por meio da análise dos lugares de fala dos participantes do evento social, a par de outras análises.

Voltando a Bakhtin, este estudioso entende que haveria duas esferas comunicativas: as esferas do cotidiano, que se reportariam às relações íntimas, familiares, comunitárias, etc., e as esferas dos sistemas ideológicos constituídos, que se refeririam à moral social, à arte, à ciência, à religião, à política, à mídia, etc. Rojo (2005, p. 197) mostra como tais esferas condicionam o discurso:

Em cada uma destas esferas comunicativas, os parceiros da enunciação podem ocupar determinados lugares sociais - e não outros - e estabelecer certas relações hierárquicas e interpessoais - e não outras; selecionar e abordar certos temas - e não outros; adotar certas finalidades ou intenções comunicativas - e não outras, a partir de apreciações valorativas sobre o tema e sobre a parceria.

Tais como os enunciados, os gêneros bakhtinianos também de definem como tipos temáticos, estilísticos e composicionais dos enunciados singulares. O lugar que ocupa cada 
gênero, ou seja, o seu campo predominante de existência, torna-o insubstituível. Bakhtin nomeia esse campo, o cronotopos, relacionado à situação de interação entre os gêneros, conforme elucida Rodrigues (2005, p. 165):

Cada gênero está assentado sobre um diferente cronotopos, pois inclui um horizonte espacial e temporal (qual esfera social, em que momento histórico, qual situação de interação), um horizonte temático e axiológico (qual o tema do gênero, qual a sua finalidade ideológico-discursiva) e uma concepção de autor e destinatário.

Rojo (2005, p. 198) busca consolidar o pensamento bakhtiniano e elenca os elementos da situação de comunicação:

i) esfera comunicativa;

ii) tempo e lugar históricos (cronotopos);

iii) participantes (relações sociais);

iv) tema;

v) vontade enunciativa/apreciação valorativa;

vi) modalidade de linguagem ou mídia.

Tudo que se abriga sob o gênero deve ser considerado em sua dimensão espacial (social) e temporal (histórica), inclusive as formas de representação, o que significa que o gênero tem existência cultural. Sobre a existência do gênero, Bakhtin observa que o gênero vive do presente, embora recorde o seu passado e a sua origem. Machado (2008, p. 159) esclarece que "os gêneros se constituem a partir de situações cronotópicas particulares e também recorrentes, por isso são tão antigos quanto as organizações sociais”.

\subsubsection{0 dialogismo bakhtiniano}

Do contructo teórico de Bakhtin, também se apresenta fundamental a noção de dialogismo, que interessa sobremaneira para o entendimento da interdiscursividade e da intertextualidade, noções que se revelam profícuas para a análise discursiva dos textos produzidos pela mídia institucional da Câmara dos Deputados. Para Bakhtin (1997 [1929]), a relação dialógica somente pode ocorrer no "texto enunciado". 
Na linguagem, enquanto objeto da linguística, não há e nem pode haver quaisquer relações dialógicas; estas são impossíveis entre os elementos no sistema da língua (por exemplo, entre as palavras no dicionário, entre os morfemas, etc.) ou entre os elementos do "texto" num enfoque rigorosamente linguístico deste. [...] Não pode haver relações dialógicas tampouco entre os textos, vistos também sob uma perspectiva rigorosamente linguística. Qualquer confronto puramente linguístico ou grupamento de quaisquer textos abstrai forçosamente todas as relações dialógicas entre eles enquanto enunciados integrais.

Barros (1996) aponta o dialogismo - princípio constitutivo da linguagem — como tema dominante nos estudos bakhtinianos, para o qual "a alteridade define o ser humano, pois o outro é indispensável para sua concepção: é impossível pensar no homem fora das relações que o ligam ao outro" (BAKHTIN, 2003, p. 35-36). Ser, portanto, significa comunicar-se com o outro.

Para Bakhtin, existe uma cadeia de comunicação, na qual cada enunciado representa um elo (BAKHTIN, 2003 apud FAIRCLOUGH, 2001, p. 134). Essa noção de "cadeia" de comunicação repercutirá na elaboração teórica de Fairclough em seu entendimento de "redes de práticas sociais" como mediadoras entre os eventos sociais e a estrutura social.

Bakhtin (2010, p. 210) trabalha ainda com o termo plurilinguismo, que seria "o discurso de outrem na linguagem de outrem". Relacionados aos gêneros, existiriam dois mecanismos dialógicos de introdução e organização do pluralinguismo no discurso: gêneros intercalados e construção híbrida. Os gêneros intercalados, de que já cuidou este trabalho, formam-se da interposição de gêneros primários e secundários. Na construção híbrida, o enunciado, segundo índices gramaticais (sintáticos) e composicionais, "pertence a um único falante", mas, na realidade, neste "estão confundidos dois enunciados, dois modos de falar, dois estilos, duas linguagens, duas perspectivas semânticas e axiológicas”.

Marcuschi (2008, p. 31, grifo do original) trata a configuração híbrida como intertextualidade intergêneros, entendendo que, nesta intertextualidade, "um gênero assume a função de outro".

A questão da intertextualidade intergêneros evidencia-se como uma mescla de funções e formas de gêneros diversos num dado gênero e deve ser distinguida da questão da heterogeneidade tipológica do gênero, que diz respeito ao fato de um gênero realizar várias sequências de tipos textuais. 
Este entendimento aplica-se à análise dos textos exarados pela Secretaria de Comunicação Social da Câmara dos Deputados do Brasil, os textos da exposição ou mostra Parlamento e Democracia, que nos servem de corpus de análise. Na busca pelo enquadramento da amostra como gênero discursivo, consideramos a noção de intertextualidade intergêneros e da "mescla de funções e formas" como um dos pontos relevantes para a delimitação de gênero.

Antes, contudo, discorremos sobre o método bakhtiniano para análise do enunciado, que se pode aplicar extensivamente para o estudo do gênero do discurso.

\subsubsection{0 método sociológico de análise do enunciado}

Já em 1929, Bakhtin propõe ordem metodológica para a análise do enunciado que privilegia as instâncias sociais, considerando aquilo que Rojo (2005, p. 198) destaca como evolução real da língua: evoluem, primeiramente, as relações sociais e, no bojo destas, a comunicação e a interação verbais. Estas, por sua vez, provocam a evolução nas formas dos atos de fala, que se refletem, finalmente, em alterações na forma da língua. Decorre daí a ordem metodológica proposta por Bakhtin (1929) para o estudo da língua (ROJO, 2005, p. 198, grifo do original):

1) As formas e os tipos de interação verbal em ligação com as condições concretas em que se realiza.

2) As formas das distintas enunciações, dos atos de fala isolados, em ligação estreita com a interação de que constituem os elementos, i. é, as categorias dos atos de fala na vida e na criação ideológica que se prestam a uma determinação pela interação verbal (leia-se gêneros; ênfase adicionada).

3) A partir daí, o exame das formas da língua em sua interpretação linguística habitual.

Aplicado ao estudo dos gêneros do discurso, o método partiria da análise dos aspectos sócio-históricos da situação de comunicação - esfera comunicativa, tempo e lugar históricos (cronotopos), participantes (relações sociais), tema ou vontade enunciativa (finalidade), apreciação valorativa, modalidade de linguagem ou mídia - para então buscar as marcas linguísticas (composição e estilo) que refletem, no texto/enunciado, aspectos da situação enunciativa (Rojo, 2005, p. 199). Sobre o último passo, pode-se dizer que se trata de uma “descrição do texto/enunciado pertencente ao gênero ligada sobretudo às maneiras (inclusive 
linguísticas) de configurar a significação”.

Para Rojo (Ibid., p. 199), por meio deste método de análise, "talvez o analista possa chegar a certas regularidades do gênero, mas estas serão devidas não às formas fixas da língua, mas às regularidades e similaridades das relações sociais em uma esfera de comunicação específica".

Finda a revisão da teoria e do método bakhtinianos para o estudo dos gêneros do discurso, passamos à visão de Fairclough sobre o tema.

\subsubsection{O gênero do discurso segundo Fairclough}

Ao adotar abordagem sociossemiótica para a análise do discurso, Fairclough, que capitaneia a instrumental Análise de Discurso Crítica (ADC), não elabora de maneira sistematizada uma teoria e um método específicos para o gênero do discurso, muito embora tenha este conceito relevância e recorrência notáveis em suas obras. Dessa forma, a noção de gênero do discurso deve ser apreendida no arcabouço teórico e metodológico desenvolvido por Fairclough para a ADC, que se dedica a investigar as conexões entre o uso de formas discursivas e a produção, a manutenção e a mudança de relações de poder (FAIRCLOUGH, 1989, p. 1), e cujos pressupostos tangenciam, em muitos pontos, as construções teóricas de Bakhtin, a começar pela definição de Fairclough (2001, p. 161) para gênero do discurso:

[...] um conjunto de convenções relativamente estável que é associado com, e parcialmente realiza [instancia, representa] ${ }^{15}$, um tipo de atividade socialmente aprovado, como a conversa informal, a compra de produtos em uma loja, uma entrevista de emprego, um documentário de televisão, um poema ou um artigo científico.

Notam-se, na definição que Fairclough elabora para gênero do discurso, confluências conceituais com Bakhtin, inclusive coincidências terminológicas. O próprio Fairclough (2001, p. 161) expressamente o assume:

[...] uma vantagem da visão (essencialmente bakhtiniana) de gênero que eu estou adotando aqui é que ele nos permite dar o devido peso não só ao modo como a prática social é limitada pelas convenções, como também à potencialidade para mudança e criatividade.

\footnotetext{
${ }^{15}$ No texto original de Fairclough, o termo é "enacts".
} 
Novamente, assinalamos, como destacamos do constructo teórico de Bakhtin, a questão da potencialidade para a mudança e a criatividade, haja vista enxergarmos nosso corpus de análise neste trabalho como nítido exemplo de "criatividade" por meio do enquadramento do discurso político a gênero discursivo distinto e determinado, uma exposição ou mostra cultural.

Estendendo a definição bakhtiniana de gênero e aproximando-a de sua noção de prática discursiva (inserida no universo maior das práticas sociais), Fairclough (Ibid., p. 161) afirma que gêneros pressupõem não somente um tipo particular de texto, "mas também processos particulares de produção, distribuição e consumo de textos".

Pode-se vislumbrar ainda, na definição faircloughiana para gênero do discurso, a aproximação da noção de ordem de discurso, inspirada em Foucault (2006, p. 8):

[...] em toda a sociedade a produção do discurso é ao mesmo tempo controlada, selecionada, organizada e redistribuída por certos números de procedimentos que têm por função conjurar seus poderes e perigos, dominar seu acontecimento aleatório, esquivar sua pesada e temível materialidade.

Diferentemente de Bakhtin, Fairclough não focaliza a estabilidade relativa em "tipos de enunciados", mas em "convenções" associadas a tipos de atividades socialmente aprovadas (FAIRCLOUGH, 2003, p. 27). Por tal razão, a sua noção de gênero associa-se à de práticas sociais.

A relação entre o que é estruturalmente possível e o que realmente acontece,
entre estruturas e eventos [textos são partes de eventos sociais], é bastante
complexa. Essa relação é mediada - há entidades organizacionais
intermediárias entre estruturas e eventos. Vamos chamá-las de práticas
sociais. [...] Práticas sociais podem ser tidas como meios de controlar a
seleção de certas possibilidades estruturais e a exclusão de outras, e a
retenção dessas seleções no decurso do tempo, em áreas particulares da vida
social.

Em tácito diálogo com Bakhtin, Fairclough (Ibid., p. 27-28) assevera que texto "não são simplesmente os efeitos dos potenciais definidos pela língua" (a língua sistema, de Bakhtin), mas entidades organizacionais intermediárias, de um tipo linguístico específico: os elementos linguísticos de redes de práticas sociais. Tais elementos seriam as ordens do discurso. 
Ainda de acordo com o linguista britânico, "uma ordem de discurso é uma rede de práticas sociais no aspecto linguístico (da língua)" ou os elementos linguísticos de redes de práticas sociais. Destarte, as ordens do discurso podem ser vistas como "organização e controle social da variação [seleção] linguística", e seus elementos - gêneros, discursos, estilos — são categorias não puramente linguísticas, mas que se localizam entre a linguagem e a não linguagem, entre o discurso e o não discurso (localização intermediária).

Na figura abaixo, adaptada de Fairclough (Ibid., p. 27), explicitam-se estas relações, não se perdendo de vista que a linguagem é considerada por aquele autor como elemento do social em todos os níveis.

Figura 11 - Relação entre estrutura social, práticas sociais, eventos sociais, segundo Fairclough (2003, p. 27).

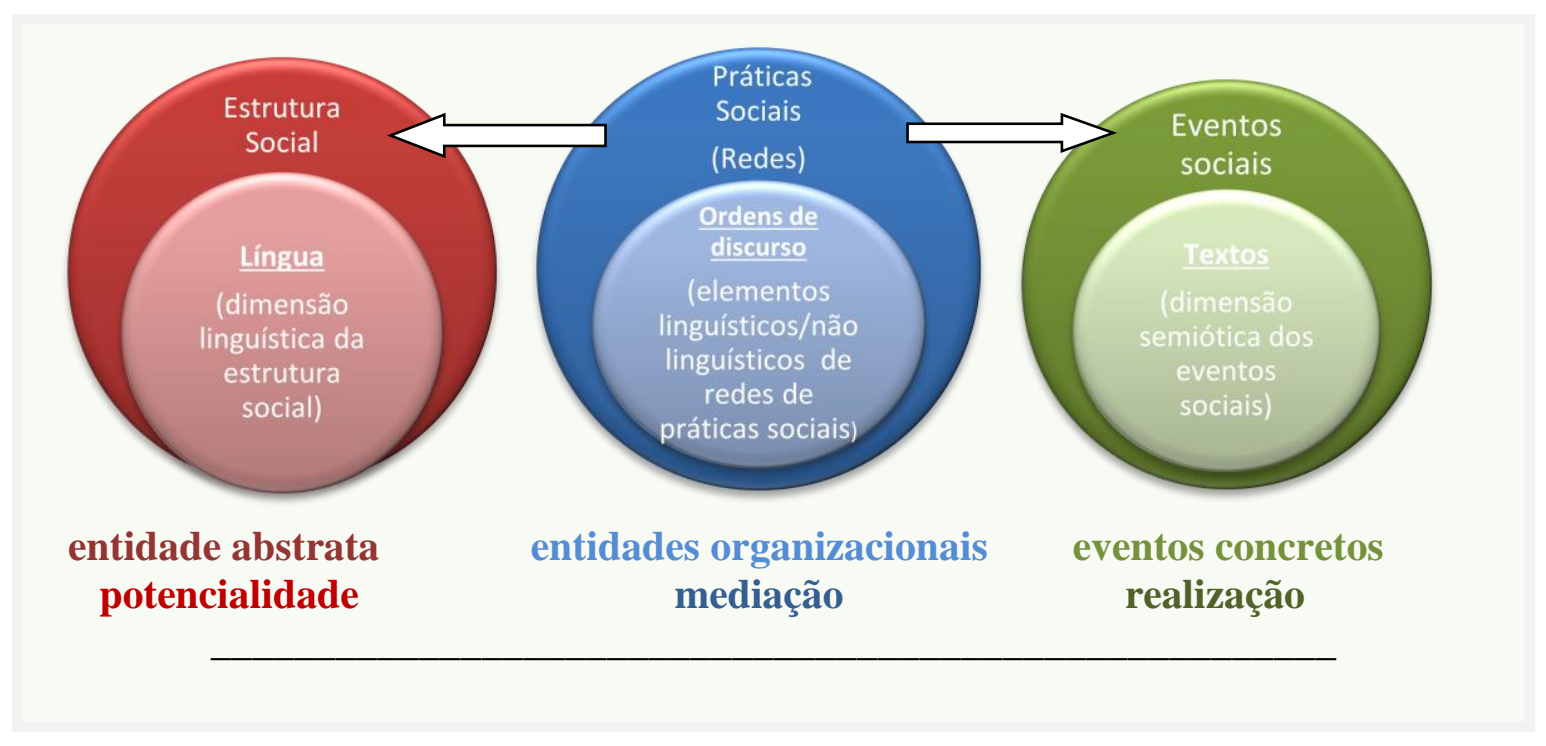

Fonte: Elaborada pela autora para este trabalho, com base em Fairclough (2003, p. 27).

Os elementos de ordens do discurso - gênero, discursos e estilos — são categorias não puramente linguísticas das práticas sociais, pois articulam o discurso (enquanto linguagem) juntamente com outros elementos sociais não discursivos. Note-se que Fairclough se refere à linguagem como elemento do social em todos os "níveis", ou seja, a estrutura social, as práticas sociais e os eventos sociais seriam níveis do social, cada qual com dimensões ou elementos linguísticos e não linguísticos. 
De acordo com o autor (2003, p. 24), os dois poderes causais que moldam o texto são, de um lado, a estrutura social e as práticas sociais, e, de outro lado, os agentes sociais (organizações, grupos e indivíduos, ou seja, as pessoas envolvidas nos eventos sociais). "Eventos sociais são causativamente moldados [em parte] por redes de práticas sociais práticas sociais definem maneiras particulares de ação [...]” (Ibid., p. 29). Concomitantemente, numa relação bidirecional, o texto muda a vida social.

O cotejo desta elaboração teórica de 2003 (teoria bidimensional) com a de 2001, em que o autor apresenta a Teoria Tridimensional do Discurso, possibilita a elaboração do seguinte quadro, que se deriva do apresentado por Fairclough em Discurso e Mudança Social (2001, p. 101) e o expande:

Figura 12 - Teoria Tridimensional do Discurso, com base em Fairclough, 2001, 2003.

\section{Prática Social}

\section{Prática Discursiva}

Hegemonia

Poder

Produção, distribuição e consumo Prática Textual
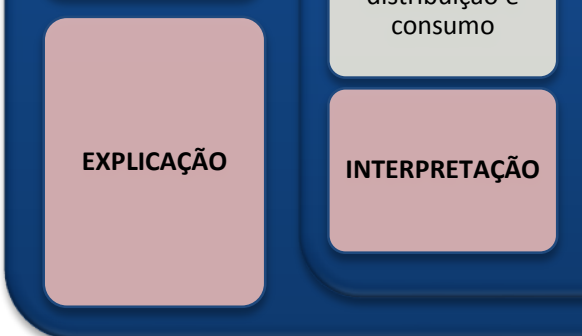

Léxico-gramática, vocabulário, gramática, coesão, coerência, intertextualidade, atos ilocucionários DESCRIÇÃO

Fonte: Quadro adaptado e expandido, pela autora, com base em Fairclough (2001, p. 101).

As ordens do discurso, como modos relativamente estáveis de agir (gêneros), de representar (discursos) e de ser (estilos), localizar-se-iam numa intersecção entre a prática social e a prática discursiva, tendo em visa que abarcam categorias não puramente linguísticas das práticas sociais. 
Impende notar que, na Teoria Tridimensional do Discurso, a ênfase da elaboração faircloughiana recai sobre a ação, a prática, a atividade, mas não despreza a estrutura social (abstrata). Privilegia o texto como forma de ação, a par da de representação. Isto porque o autor persegue não somente as condições de reprodução das hegemonias (estase social), mas também, e sobretudo, as de mudança e transformação.

O gênero é o significado acional do texto, o modo de uso da linguagem associado a uma atividade particular (FAIRCLOUGH, 2003) ou "aspectos discursivos das formas de agir e interagir por meio dos eventos sociais" (Ibid., 2006). Entendendo que essas formas de ação e interação em eventos sociais são definidas por práticas sociais e as formas como estas se organizam em redes de comunicação, o autor propõe método para a análise de gênero, que percorre três passos. O primeiro passo consiste na análise da cadeia de gêneros. Entende Fairclough que "uma cadeia de eventos deve envolver uma cadeia ou rede de comunicação diferentes, interconectada em textos que manifestam uma corrente de diferentes gêneros". $\mathrm{O}$ segundo passo apontado por Fairclough compreende a análise da mistura de gêneros em texto particular. Nesse sentido, aduz que mudança em gêneros significa mudança em como gêneros diferentes são combinados, derivando novos gêneros. O último passo seria a análise de um gênero individual em um texto particular. Para o autor, o texto particular não se encontra inserto em um gênero particular, mas, num vetor inverso, é conformado para diferentes gêneros.

Vale abrir parêntese apenas para assinalar que Fairclough \& Fairclough (2012), ao proporem nova abordagem para o discurso político e enfatizarem seu caráter argumentativo prático, apresentam a conexão entre as representações e a agência humana, ou seja, como as representações motivam a ação. Nesta obra, aprofunda-se o entendimento do argumento, que, segundo Fairclough (2006), é pré-gênero, ao lado do diálogo e da narrativa.

No que se refere à ênfase na representação, Fairclough (2001. p. 50) admoesta a linguística crítica do grupo da Universidade de East Anglia na década de 70, protagonizado por Fowler et al (1979), e Kress e Hodge (1988):

Mais geralmente, o que está em questão é a visão exclusivamente descendente do poder e da ideologia na linguística crítica, que corresponde a uma ênfase encontrada também na abordagem althusseriana do grupo de Pêcheux [...] na estase social e não na mudança, nas estruturas sociais e não na ação social, e na reprodução social e não na transformação social. 
Advoga Fairclough (2001, p. 50) a imprescindibilidade de uma teoria social do discurso que proceda à reavaliação desses "dualismos tomados como polos em relação de tensão, em vez de optar-se por um membro de cada par e rejeitar o outro como se fossem mutuamente exclusivos".

Ao se reportar à "visão exclusivamente descendente do poder e da ideologia", o autor inglês aponta, e critica, a tendência a se tomarem como tácitos os efeitos ideológicos, ao se enfatizarem estrutura e texto como produto, relegando a segundo plano os processos de produção e principalmente de interpretação de texto — "os textos podem estar abertos a diferentes interpretações" (FAIRCLOUGH, 2001, p. 49).

Ainda em comentário ao quadro de Fairclough — quadro revisitado e reelaborado neste estudo - , trasladam-se as palavras do próprio autor para elucidar aquele esquema (FAIRCLOUGH, 2003, p. 22):

\begin{abstract}
Qualquer "evento" discursivo (isto é, qualquer exemplo de discurso) é considerado como simultaneamente um texto, um exemplo de prática discursiva e um exemplo de prática social. A dimensão do "texto" cuida da análise linguística de textos. A dimensão da "prática discursiva", como interação, na concepção "texto e interação" de discurso, especifica a natureza dos processos de produção e interpretação textual — por exemplo, que tipo de discurso (incluindo "discurso" no sentido mais socioteórico) são derivados e como se combinam. A dimensão de "prática social" cuida de questões de interesse da análise social, tais como as circunstâncias institucionais e organizacionais do evento discursivo e como elas moldam a natureza da prática discursiva e os efeitos constitutivos/construtivos referidos anteriormente.
\end{abstract}

É na dimensão da prática social que se encontram os elementos da ordem do discurso: gêneros (ação, modo de agir), discurso (representação, modo de representar) e estilo (identificação, modo de ser). Estes elementos da ordem do discurso guardam correlação direta com os significados da linguagem - acional, representacional e identificacional —, que Fairclough postula, com base em Halliday (1994): 
Figura 13 - Cotejo entre LSF e AD. Elementos da ordem do discurso.

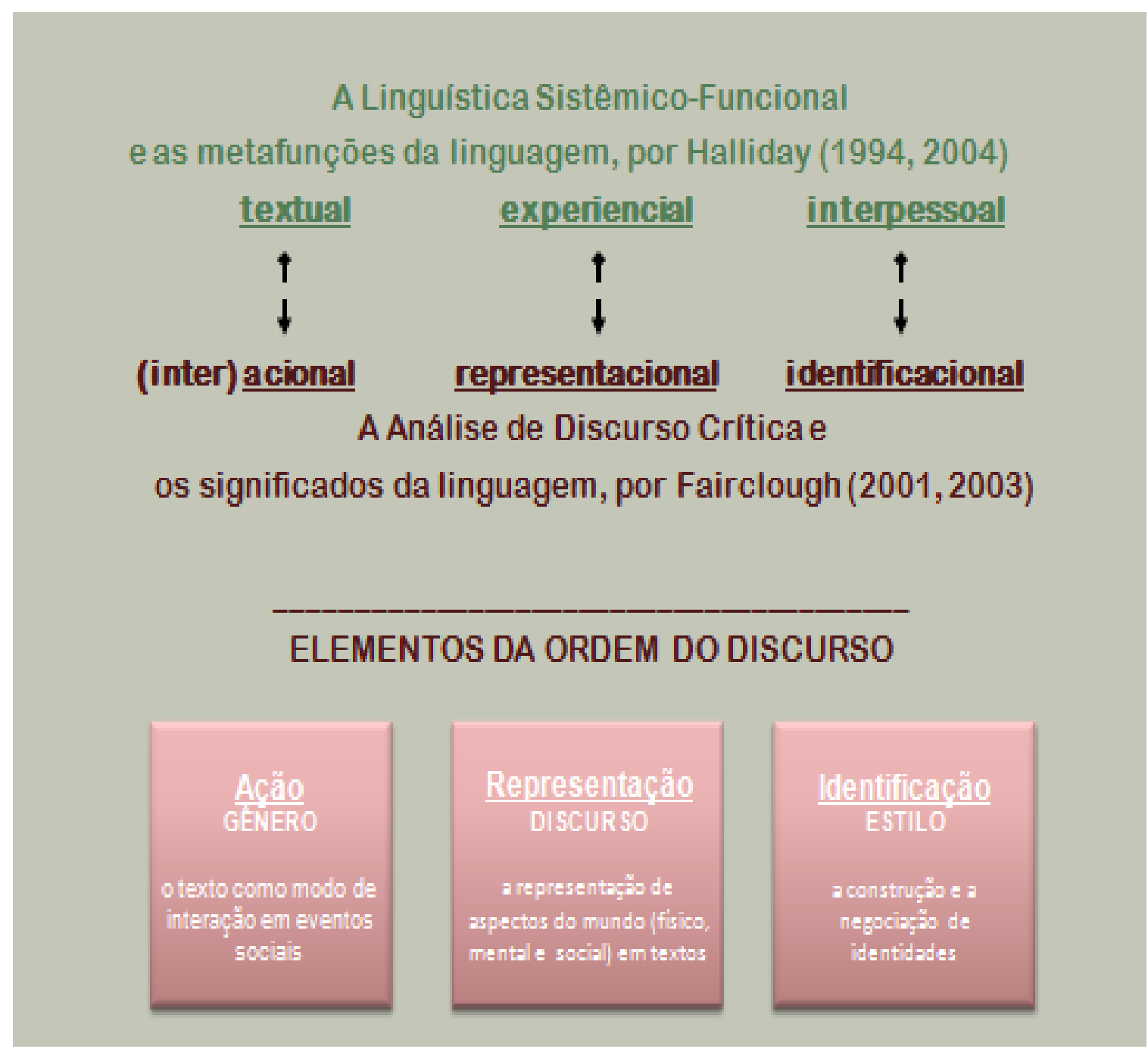

Fonte: Elaborado pela autora para este estudo, com base em Fairclough (2001, 2003)

Por meio do significado acional, o gênero toma o texto como modo de (inter)ação em eventos sociais. A análise da configuração genérica, no significado acional, busca as evidências da intertextualidade e da suposição. Por meio do significado representacional, os textos representam os aspectos do mundo físico, mental e social. Neste ponto, a configuração genérica dos textos desvenda-se por meio da análise de categorias como interdiscursividade e relações semânticas. Sem desconsiderar o significado identificacional, pois que todos os significados se interligam, empregam-se, no exame do corpus, primordialmente estas categorias de análise: interdiscursividade (intertextualidade constitutiva), intertextualidade (intertextualidade manifesta), suposição e relações semânticas. 
Enfim, por meio do significado identificacional, focalizam-se o estilo e o modo como se constroem e se negociam as identidades dos atores sociais. Para o descortino da configuração genérica, consideram-se a modalidade e a avaliação. Reiteramos que não são estas as categorias que nortearão a análise do gênero do discurso neste estudo, embora sejam tangeciadas em muitos pontos da análise.

Não é demasiado lembrar que a linguagem povoa as três áreas de modo dinâmico, sem que se excluam quaisquer delas. Izabel Magalhães (apud FAIRCLOUGH, 2001, p. 12) aponta que, para o linguista inglês, a reconfiguração ou mutação dos elementos da ordem do discurso respondem pela mudança discursiva, cujos efeitos se dão sobre "os sujeitos e suas identidades, as relações sociais e os sistemas de conhecimento e crença". As ordens do discurso, portanto, têm primazia sobre os tipos particulares de discurso, sendo estes "constituídos como configurações de elementos diversos de ordens de discurso" (FAIRCLOUGH, 2001, p. 159).

Consoante Fairclough (Ibid., p. 91), o discurso é "um modo de ação, uma forma em que as pessoas podem agir sobre o mundo e especialmente sobre os outros". Mas não somente as pessoas, também as instituições o fazem por meio de práticas discursivas. E sobre as ordens do discurso institucionais ou societárias, Fairclough (2001, p. 67) assevera:

\begin{abstract}
A ênfase nas relações interdiscursivas [por Foucault] tem importantes implicações para a análise do discurso, já que põe no centro da agenda a investigação sobre a estruturação ou articulação do que eu chamaria, usando um termo foucaultiano, ordens de discurso institucionais ou societárias — a totalidade das práticas discursivas dentro de uma instituição ou sociedade, e o relacionamento entre elas.
\end{abstract}

Com essa menção específica a Foucault e, em seguida, ao trabalho de Pêcheux, Fairclough introduz sua elaboração teórica sobre o interdiscurso. Na seção seguinte, discorremos acerca das noções de interdiscursividade, intertextualidade e suposição, que se relacionam com as noções de gênero do discurso e servem de base de análise dos textos que compõem o corpus. 


\subsubsection{Fairclough, a interdiscursividade, a intertextualidade e a suposição}

Fairclough constrói sua noção de interdiscursividade e intertextualidade conclamando, entre outros, o pensamento de dois filósofos: Foulcault (de que também herda e reelabora a noção de "ordens de discurso") e de Pêcheux. Deste, contudo — é preciso dizer —, diverge quanto ao assujeitamento ao discurso, ou seja, o posicionamento não intervencionista do participante interativo: Pêcheux enfatiza a constituição do sujeito pelo discurso, não o inverso.

Os primeiros estudos arqueológicos de Foucault (1972) preliminarmente focalizam a visão constitutiva do discurso (constituidor de estruturas conceituais, objetos do conhecimento, sujeitos e formas sociais do "eu", e relações sociais). Ademais, tratam da interdependência das práticas discursivas e asseveram que os textos evocam outros textos, contemporâneos a estes ou historicamente anteriores, e os transforma. A este fenômeno de textos que se evocam e se transformam, Fairclough chama de intertextualidade. Mas aduz Foucault, outrossim, que "qualquer tipo de prática discursiva é gerado de combinações de outras práticas discursivas”. Fairclough aponta esse fenômeno, na dimensão da prática discursiva, como interdiscursividade (ou intertextualidade constitutiva).

Assim, o termo interdiscursividade remete à noção de ordens do discurso institucionais ou societárias, que seria o conjunto de todas as práticas discursivas de uma instituição ou sociedade, e as relações entre tais práticas. A forma como se estruturam e articulam as ordens do discurso - gênero, discurso e estilo - pode ser investigada por meio da análise das relações interdiscursivas.

Para Foucault (1972, p. 98) — que, por sua vez, também se inspira em Bakhtin — "não pode haver enunciado que de uma maneira ou de outra não reatualize novamente outros enunciados". Com tal afirmação, Foucault trata das relações entre enunciados como interdiscursividade. Para Fairclough (2001, p. 52), a interdiscursividade trata da "relação entre formações discursivas ou, mais genericamente, entre diferentes tipos de discurso", ao passo que a intertextualidade trata da "relação entre textos".

Pêcheux empresta de Foucault o termo "formação discursiva" e atribui à expressão o seguinte significado: "aquilo que em uma dada formação ideológica [...] determina 'o que pode e deve ser dito"' (Pêcheux, 1982, p. 111, itálico no original). A expressão trata de delineamento discursivo, ou seja, constrição ou coerção discursiva, que se relaciona com a 
noção de gênero do discurso. Ao tratar do pensamento de Pêcheux, Fairclough (2001, p. 54) ressalta nele a relação entre discurso e ideologia, ou, no âmbito do gênero do discurso, formação discursiva e formação ideológica.

Fairclough (2001, p. 53), ao analisar o conceito que Pêcheux constrói para "formação discursiva", extrai deste conceito algumas conclusões:

i) as palavras mudam de sentido conforme a posição de quem as emprega;

ii) formações discursivas diferentes podem compartilhar determinadas palavras ou expressões, mas o sentido destas diferirá em cada formação, pois é a relação das palavras e expressões entre si que determina seu sentido (a palavra militante pode significar "ativista", para o discurso sindical, mas significará "subversivo" para o discurso conservador de direita);

iii) os sujeitos são constituídos em relação às formações discursivas particulares e seus sentidos;

iv) as formações discursivas particulares são faces linguísticas de "domínios de pensamento sócio-historicamente constituídos na forma de pontos de estabilização que produzem o sujeito e simultaneamente junto com ele o que lhe é dado ver, compreender, fazer, temer e esperar" (Pêcheux, 1982, p. 112-113, itálico no original);

v) o complexo de formações discursivas relacionadas compreende o interdiscurso.

Seguramente Fairclough apoiou-se nestas conclusões sobre o pensamento de Pêcheux - especialmente quanto à mudança dos sentido da palavra, conforme a formação discursiva e a posição de quem as emprega (conclusões i e ii, acima) —, para elaborar a sua noção de recontextualização.

“A intertextualidade constitui uma questão de recontextualização". Com essa afirmação, Fairclough (2003, p. 70) apresenta uma categoria de análise preciosa para este estudo crítico multimodal, isto porque a recontextualização pode levar à ambivalência os termos empregados nos discursos que os incorpora - e os textos incorporados na exposição Parlamento e Democracia constroem-se majoritariamente por meio da intertextualidade manifesta e da recontextualização. Realocados, os textos reconfiguram-se de um contexto a outro, ressignificando-se. 
Fairclough (2001) também se reporta à noção de relexicalização para a utilização de termos historicamente associados a outras atividades e relações, como estratégia de legitimação de deslocamentos de sentido. A expressão "manifestações populares", por exemplo, transforma-se substancialmente, em termos semióticos, quando empregada em um texto datado de 1822 e, em outra instância, quando empregada em um texto do século XXI. E a distinção semântica torna-se ainda mais robusta no contexto das históricas manifestações de rua ocorridas no País a partir de junho de 2013. Analisam-se esta e outras recontextualizações no exercício analítico em capítulo adiante.

Vale dizer que a recontextualização relaciona-se à tendência de alteração da linguagem chamada comodificação (Ibid., p. 255), em que domínios e instituições sociais, sem propósitos econômicos, organizam-se e definem-se com base na produção, distribuição e consumo de mercadorias. O discurso mercadológico recontextualiza-se naqueles domínios e instituições sociais.

Para a análise do fenômeno da recontextualização, Fairclough (Ibid. 255) propõe procedimento metodológico que consiste de dois passos: o levantamento da relação entre o relatado e o original (o evento que é relatado) e o levantamento da relação entre o relatado e o resto do tex to no qual ele ocorre, ou seja, como o relato se configura no texto geral.

Essa noção de recontextualização, da Teoria Social, encontra certa equivalência na Teoria Semiótica Social, guardadas todas as diferenciações de base teórica: referimo-nos ao conceito de ressemiotização proposto por Iedema (2003), que, aplicado à análise multimodal, expõe a forma como os sistemas semióticos se traduzem de um sistema a outro como processos sociais (por exemplo, uma reunião de trabalho transformada em ata) e, além disso, interpela os motivos pelos quais se mobiliza determinado sistema semiótico.

Voltando a Pêcheux, não se pode deixar de notar a correlação da concepção de interdiscurso de Pêcheux com as noções de gênero de Bakhtin, quando aquele autor postula que as formações discursivas são "pontos de estabilização" dos domínios do pensamento que constituem o sujeito: para Bakhtin, a linguagem é constitutiva e o gênero são tipos relativamente estáveis de enunciados. Ademais, para Pêcheux, o que pode e deve ser dito, assim como o seu significado, está constrito por aquilo que o autor denomina "formação ideológica". Para Bakhtin, as esferas da atividade humana compreendem-se como domínios ideológicos, e a estas esferas da atividade humana relacionam-se tipos relativamente estáveis 
de enunciados, ou seja, os gêneros discursivos.

A distinção entre interdiscursividade e intertextualidade torna-se mais clara no momento em que Fairclough (2001, p. 136) elucida, com base na postulação dos analistas de discurso franceses Authier-Révuz (1982) e Maingueneau (2013), a intertextualidade manifesta como oposta à de intertextualidade constitutiva (interdiscursividade).

$\mathrm{Na}$ intertextualidade manifesta, outros textos estão explicitamente presentes no texto sob análise: eles estão "manifestamente" marcados ou sugeridos por traços na superfície do texto, como as aspas. Observe, entretanto um texto pode "incorporar" outro texto sem que o último esteja explicitamente sugerido: pode-se responder a outro texto na forma como se expressa o próprio texto [...] $\mathrm{Na}$ intertextualidade constitutiva de um texto [...] é a configuração de convenções discursivas que entram em sua produção.

Observe-se, portanto, que na intertextualidade manifesta a ênfase recai sobre o texto, enquanto na intertextualidade constitutiva o foco se dirige às convenções discursivas. Nas relações de interdiscursividade, os elementos das ordens de discurso se mostram instáveis e heterogêneos, ou seja, intertextuais em sua constituição.

Fairclough (2003, p. 54 e 63) trata, outrossim, do contraste entre intertextualidade (manifesta) e suposição: naquela, a diferença é largamente marcada, no que diz respeito a incorporar ao texto outras vozes; nesta, a diferença apresenta-se mitigada, esmaecida. Dessa forma, a intertextualidade acentua a diferença e resulta mais dialógica, enquanto a suposição reduz a diferença e se traduz em menos dialogicidade.

As suposições, nem sempre marcadas, mas invariavelmente relacionadas aos matizes ideológicos subjacentes à construção textual, distinguem-se em suposições existenciais (sobre o que existe), proposicionais (sobre o que é, pode ser ou será) ou morais (sobre o que é bom ou desejável). Finalmente, Fairclough correlaciona intertextualidade, seletividade e gênero, na medida em que o processo de seleção daquilo que será incluído ou excluído dos eventos e textos representados constitui a própria intertextualidade e esta, como se vem arguindo, relaciona-se com o gênero.

As suposições, de Fairclough, seriam um tipo de implícito que, na Pragmática, denomina-se pressuposição. Estas são suposições relacionadas ao discurso, que tomam como dado o que se supõe sabido e acreditado. 
O quadro abaixo, com base em Verschueren (1999 apud FAIRCLOUGH, 2003, p. 84), busca organizar e esclarecer essa relação.

Quadro 2 - Tipos de implícitos, com base na Pragmática de Verschueren (1999).

\begin{tabular}{|l|l|}
\hline Pressuposição & $\begin{array}{l}\text { Suposição relacionada ao discurso; toma como } \\
\text { dado o que se supõe sabido ou acreditado. Pode } \\
\text { ser ou não estratégica. }\end{array}$ \\
\hline Implicações lógicas & $\begin{array}{l}\text { Sentidos inferidos logicamente das características } \\
\text { da linguagem (marcas na superfície textual). }\end{array}$ \\
\hline Implicaturas conversacionais padrão & $\begin{array}{l}\text { Sentidos convencionalmente inferidos (com base } \\
\text { nas quatro máximas conversacionais de Grice: a } \\
\text { informação deve ser suficiente, verdadeira, } \\
\text { relevante e clara). }\end{array}$ \\
\hline Implicaturas conversacionais não padrão & Estratégia de prevenção do explícito. \\
\hline
\end{tabular}

Fonte: Elaborado pela autora para este estudo, com base em Verschueren (1999) e Fairclough (2003).

\subsubsection{Fairclough, hibridismo de gênero e outras tendências discursivas}

Ao analisar a prática discursiva sob o enfoque da intertextualidade, Fairclough (2001, p. 149) relaciona as noções de interdiscursividade e hibridismo de gêneros, o que é central para o entendimento do hibridismo de formações discursivas identificadas em nosso corpus de análise.

Meu foco para esse exemplo é sobre a interdiscursividade (intertextualidade constitutiva) dentro do quadro da luta e da transformação hegemônica, sobre as condições e os mecanismos sociais para a emergência de um novo tipo de discurso que é constituído por meio de uma nova configuração dos tipos existentes, e, especificamente, a emergência de um discurso híbrido de informação e publicidade (ou de "falar-e-vender").

Cada vez mais recorrentes nas ordens de discurso institucionais, os textos que simultaneamente informam e publicizam atestam o movimento colonizador da publicidade de mercado para domínios novos, inclusive para o domínio da comunicação levada a cabo pelas instituições do Estado. Essas novas configurações, esse hibridismo discursivo que leva aos textos públicos institucionais configurações discursivas atreladas a textos propagandísticos, 
testificam a tendência à coodificação vaticinada também por Fairclough (Ibid., p. 151):

A comodificação, a expansão do consumismo e a marquetização tem efeitos generalizados sobre as ordens do discurso, variando de uma reestruturação penetrante de ordens de discurso institucionais sob o impacto do movimento colonizador do discurso da publicidade, do mercado e da administração [...]

Colonizados e híbridos, os discursos políticos albergam elementos dos discursos promocionais ou de consumo, trazendo para o âmbito do público (no caso, estatal) o que é da esfera do privado, do mercado.

Fairclough $(2003,2006)$ assinala, ainda, outras tendências nas práticas discursivas do Novo Capitalismo, como a tecnologização, que implica a expansão do discurso estratégico para novos domínios. Assim, habilidades e competências requeridas para a elaboração do discurso midiático, majoritamente multimodais, passam a ser demandadas pelos produtores do discurso político, e vice-versa. Foucault (2006) credita especial importância às tecnologias em formas modernas de poder, de que a linguagem é exemplo. A tendência à tecnologização guarda intrínseca relação com o fenômeno da convergência cultural ou das mídias, conforme já se alardeou.

Outra tendência seria a democratização do discurso, que tem como fito (políticoideológico) a retirada de desigualdades e assimetrias de direitos, obrigações e prestígio discursivo e linguístico de certos grupos sociais. Esta tendência guarda relação com a informalização do discurso e a conversacionalização, as quais, por sua vez, relacionam-se à noção de hibridismo de gêneros primários (prevalentemente orais) e secundários (prevalentemente escritos), fenômeno sobre o qual já discorremos. Esse afastamento de desigualdades consiste em estratégia discursiva de aproximação e identificação entre o produtor e o destinatário da mensagem, relação que é nítida nos textos do corpus de análise, entre o produtor Parlamento e o destinatário cidadão.

Relembramos que, para a análise dos gêneros, Fairclough (2003) propõe um método que percorre três passos. $\mathrm{O}$ primeiro passo consiste na análise da cadeia de gêneros. $\mathrm{O}$ segundo passo apontado por Fairclough compreende a análise da mistura de gêneros em um texto particular. O último passo, a análise de um gênero individual em um texto particular.

A seguir, entenderemos como Kress constrói a sua teoria e o seu método para a análise 
dos gêneros textuais (não mais discursivos, tendo em vista a definição ampla que o autor elabora para o termo "texto").

\subsubsection{O gênero do texto segundo Gunther Kress}

Pioneiro na formulação da Teoria Semiótica Social da Multimodalidade, Gunther Kress, Professor de Semiótica e Educação no Departamento de Cultura, Comunicação e Mídia do Instituto de Educação da Universidade de Londres, propugna que os elementos não verbais não podem ser desprezados no estudo dos gêneros textuais, pois para os que se interessam pelo significado social construído pelos recursos semióticos, o foco na linguagem não basta. A linguagem seria apenas um dos diversos sistemas de signos que colaboram para a construção do sentido (KRESS et al, 2000, p. 270).

Ao sugerir que a produção de sentidos no discurso se desenvolve com base em sistemas de signos, e que esses sistemas de signos relacionam-se de forma complexa com as práticas sociais, nos contextos sociais em que figuram, Kress opõe à Semiótica tradicional aquilo que entendeu chamar de Semiótica Social. Assim Hodge e Kress (1988, p. 261) a definem: "o estudo geral da semiose, isto é, dos processos da produção e reprodução, recepção e circulação dos significados em todas as suas formas, utilizadas por todos os tipos de agentes de comunicação". Para os autores, o foco na semiose humana implica entendê-la como fenômeno inerentemente social em termos de origem, função, contexto e efeito. E acrescentam que os significados sociais "são construídos por meio de uma série de formas, textos e práticas semióticas de todos os períodos da história da sociedade humana”. Neste ponto, notamos como se aflora a inspiração em Bakhtin.

Contudo, essa perspectiva discursivo-semiótica da linguagem - em que se insere a elaboração teórica de Gunther Kress — diferencia-se fundamentalmente da de Bakhtin e de Fairclough quanto ao entendimento da estabilidade para a caracterização do gênero discursivo. Ao enfatizar os traços de instabilidade dos gêneros textuais, Kress propõe que estes são essencialmente variáveis, tanto cultural quanto historicamente: apresentam-se em constante mutação.

Desta instabilidade decorre a noção de Kress para o hibridismo dos gêneros - tema 
sobre o qual também discorre Fairclough. O fenômeno, para Kress, resulta da multiplicidade das formações discursivas e categorias de gênero, que, numa cadeia complexa - aqui se vislumbram, sim, as elucubrações de Bakhtin —, podem-se apresentar subordinados a outros.

Vale dizer que a concretização dos discursos políticos institucionais públicos tem-se mostrado bastante seminal nesse sentido. Cada vez mais aparelhados para se inserir “competitivamente" (em termos de audiência) no grande mercado das comunicações de massa - e com a vantagem de prescindirem do lucro para sua subsistência -, os órgãos de comunicação das instituições públicas no Brasil produzem e fazer circular textos de cunho político sob o efúgio de gêneros os mais diversificados.

Voltanto a Bakhtin, é preciso notar que, enquanto Bakhtin define os gêneros como “tipos de enunciados", para Kress (1989, p. 19) os gêneros são "tipos de texto", tipos que codificam os traços característicos e as estruturas dos eventos sociais, bem como os propósitos dos participantes discursivos envolvidos naqueles eventos. O que demarca o gênero, portanto, são certos traços característicos dos eventos sociais, as estruturas sociais que abarcam os textos, e as intenções ou finalidades dos participantes.

Num primeiro momento, Kress entende que as posições desses participantes constroem-se por meio do discurso e do gênero em que estes se inserem, isto é, são determinados pelos significados culturais e históricos (expressos nos discursos em determinado momento histórico) e as relações estabelecidas na instanciação do evento social. O gênero, portanto, estabeleceria os papéis e os lugares de fala dos participantes discursivos, que, por assumirem posições simétricas ou assimétricas na relação discursiva, seriam sujeitos de direitos ou de deveres.

Analisando pelo viés dessas relações entre os participantes, poder-se-ia chegar ao delineamento do gênero. Em outras palavras, por meio do destrinçamento das relações entre os sujeitos e a perquirição da posição que assumem na instanciação do evento social, em termos de acesso à informação ou de domínio de determinado conhecimento, diferenciam-se os gêneros. Kress fala, exempli gratia, de maior grau de assimetria nos papéis sociais dos participantes discursivos no caso da relação aluno/professor, comparada à relação entrevistado/entrevistador; no primeiro caso, o professor valida a informação dada pelo aluno; o segundo caso, o entrevistador apenas aceita o que disse o entrevistado.

Destrinçam-se, abaixo, os elementos da definição de gênero, para Kress, a fim de se 
obter dela maior clareza:

Figura 14 - Elementos da definição de gênero de texto, para Gunther Kress (1989)
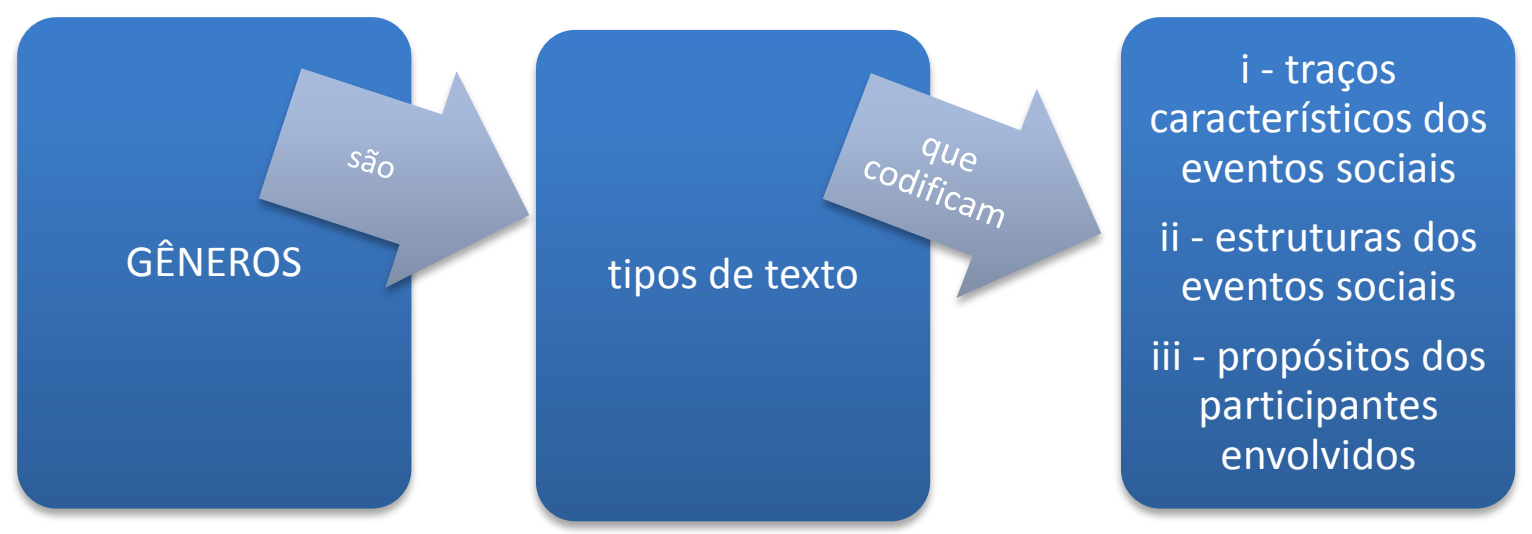

Fonte: Elaborado pela autora para este estudo, com base em Kress (1989).

Não é por outro motivo que Kress aponta o texto como unidade de análise, e os sentidos construídos e negociados no texto como objeto do analista semiótico. Ademais, sintetiza que recai sobre o texto dupla determinação: os significados sociais dos discursos que nele figuram e as formas, significados e restrições de determinado gênero. Assim Kress (1995, p. 7) constrói sua noção de texto:

Um "tecer" junto, um objeto fabricado que é formado por fios "tecidos juntos" - fios constituídos de modos semióticos. Esses modos podem ser entendidos como formas sistemáticas e convencionais de comunicação. Um texto pode ser formado por vários modos semióticos (palavras e imagens, por exemplo), portanto podemos chegar à noção de multimodalidade. Com o advento de materiais computadorizados, multimídia e interacionais, esta forma de conceituar a semiose se torna cada vez mais pertinente.

Como a fundamentação teórica de Kress se inspira em Halliday (1994), aquele semioticista entende que não se pode desprezar, no processo de produção do signo (o que o autor chama de sign-making), as dimensões contextuais. 
O contexto situacional é o contexto mais imediato, em que ocorrem os eventos sociais característicos de uma instituição particular. Nestes eventos, que se estabelecem sob determinada finalidade ou propósito - estes que, por sua vez, determinam a forma como ocorrem os eventos sociais - relacionam-se socialmente os participantes discursivos. Regras de gênero determinam quem tem legitimidade ou autoridade para falar de determinados lugares, relacionadas geralmente ao acesso diferencial a certos saberes ou conhecimentos legitimados. Mas não se pode esquecer que o discurso se conforma no contexto sóciohistórico, o contexto mais amplo da cultura. Neste se define o que se pode dizer, quem tem autoridade para dizer e as formas apropriadas para tanto. Estas seriam restrições discursivas e genéricas.

Na figura abaixo, as dimensões contextuais e seus elementos:

Figura 15 - Dimensões contextuais do processo de produção do sentido, segundo Kress (1989).

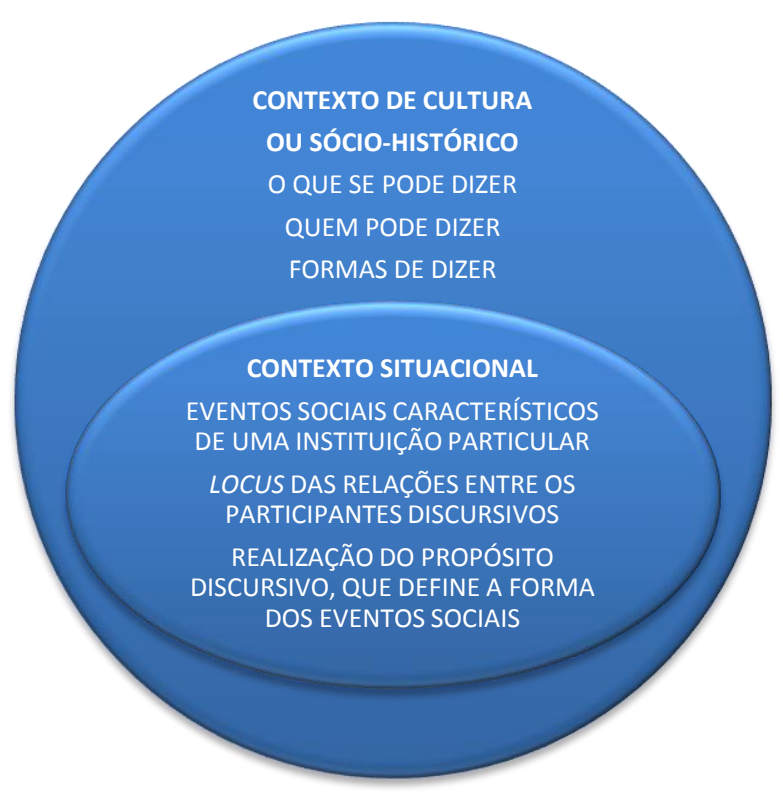

Fonte: Elaborado pela autora para este estudo.

A linguagem, prática de produção de significados e prática social, inserida em contextos sociais, históricos e culturais, sujeita-se a ingerências ideológicas e hegemônicas. É justamente este viés que junge a Teoria Semiótica Social da Multimodalidade e a Análise de 
Discurso Crítica, tendo sido esta posterior àquela, conforme elucida Balloco (2005, p. 68, grifos do original):

Do ponto de vista histórico, a análise crítica do discurso é tributária dos estudos iniciados por pesquisadores na área da linguística crítica, da década de 1970 (representada por estudos do próprio Kress, como Kress \& Hodge, 1979; ou Fowler et al, 1979), que inauguraram a tradição da linguagem de feição "intervencionista" (cf. Fowler, 1996), voltada para questões de representação e de ideologia.

Balloco (Ibid., p. 68) acrescenta que ambas as perspectivas, críticas, buscam o desvelamento das relações entre as representações discursivas (do mundo, de quem somos e como agimos em nosso grupo social) e os sistemas de poder que autorizam estas representações e suprimem outras. Considerando que o discurso invariavelmente se constitui em um ponto de vista, Fowler compreende que as representações em um sistema semiótico como a linguagem conforma um processo estruturador, em que se articulam permanentemente valores e proposições implícitos. A atitude intervencionista se dispõe a justamente vistoriar esses valores e essas proposições hegemonicamente representados em discursos públicos, tais como os discursos políticos e midiáticos.

\subsubsection{Método para o estudo de gêneros textuais, consoante Kress}

Para Kress (1989, p. 37), discursos e gêneros definem as "posições do sujeito" ou, em outros termos, estabelecem os lugares a partir dos quais podem manifestar-se os atores sociais e os papéis por estes desempenhados no evento social de que participam, mas também no âmbito maior dos valores da instituição em que se concretiza tal evento. Dessa forma, os significados amplos do contexto de cultura e dos discursos que nela circulam, em determinado contexto histórico, estabelecem as posições do sujeito, que também se delimitam pelas relações sociais que ocorrem num determinado evento social.

Com foco nas restrições discursivas e genéricas impostas pelo contexto sóciohistórico, Kress (1989, p. 19) propõe método para o estudo de gêneros textuais (atente-se para o conceito amplo de "texto" para a Semiótica Social, supradito), que se constitui de três focos de análise, não necessariamente consecutivos: a análise dos lugares de fala dos participantes 
discursivos, consoante o relacionamento que se estabelece entre estes no evento social característico e os significados mais amplos de determinada cultura (manifestados nos discursos que nela circulam, em determinado momento histórico); a análise dos propósitos reconhecidos ou finalidades em que se estabelecem os eventos sociais; e a análise dos elementos componentes da organização textual, ou seja, a forma como se materializam os eventos sociais. Em suma, são três os fatores constitutivos do gênero: lugares de fala, finalidade e organização textual.

Por parecer-nos mais apropriado, neste complexo arcabouço teórico-metodológico que se vem construindo para a análise do gênero do discurso (a par do gênero textual, na acepção multimodal de texto), adotamos o método proposto pela Semiótica Social de Kress, sem desprezar as contribuições indispensáveis da ADC de Fairclough, mormente quanto às questões de intertextualidade. Decerto Bakhtin, de cujas elaborações sociodiscursivas derivam as análises sociossemióticas do gênero, também se evoca neste estudo.

Note-se que o método proposto pela Semiótica Social engloba elementos do contexto de situação, o contexto mais imediato do evento social, mas este se conforma no domínio do contexto mais amplo de cultura, ou seja, o contexto sócio-histórico, que delimita, em instância final, o gênero do discurso multimodal. Tendo sido já parcialmente delineado no primeiro capítulo deste trabalho - até porque entendemos não ser plausível um delineamento completo e absoluto - , o contexto sócio-histórico apresentou alguns aspectos da mudança na paisagem semiótica, na passagem do logocentrismo para a multimodalidade (ali considerada fenômeno e teoria), bem assim os efeitos estruturantes da chamada cultura da convergência na instituição Câmara dos Deputados do Brasil.

Antes de colocarmos em prática o método proposto pela Semiótica Social para o enquadramento dos textos que este trabalho toma para corpus de análise em determinado gênero discursivo, discorremos, a seguir, sobre as categorias de análise da Gramática Visual e o Princípio de Integração dos Recursos Semióticos, propostos pela Gramática do Design Visual, de Gunther Kress e Theo van Leeuven (1996), pois estes são preciosos para a análise multimodal, mas também crítico-discursiva, que se faz do gênero discursivo no capítulo seguinte.

\subsubsection{Categorias para a Análise Multimodal}


Entende Kress \& van Leeuwen (1996) que um "texto multimodal é aquele cujo significado se realiza por mais de um código semiótico". Considerando que a nossa análise se aplica a textos multimodais, no quadro abaixo subsumimos as categorias de análise de textos imagéticos propostos por Kress \& van Leeuwen (Ibid.) em sua Gramática do Design Visual:

Quadro 3 - Categorias de Análise da Gramática do Design Visual, com base em Kress \& van Leeuwen (1996) e Ferraz (2015)

\begin{tabular}{|c|c|c|}
\hline \multirow[t]{2}{*}{$\begin{array}{l}\text { Participante } \\
\text { Objetos e elementos presentes em } \\
\text { uma composição gráfico visual. }\end{array}$} & \multicolumn{2}{|c|}{$\begin{array}{l}\text { Representado } \\
\text { Pessoa, lugar, coisa (concreta ou abstrata) de que se está falando, } \\
\text { escrevendo ou produzindo imagens. }\end{array}$} \\
\hline & \multicolumn{2}{|c|}{$\begin{array}{l}\text { Interativo } \\
\text { Receptores da mensagem (viewer, no caso de imagens representadas) }\end{array}$} \\
\hline \multirow[t]{5}{*}{$\begin{array}{l}\text { Processos narrativos } \\
\text { Participantes (representados) } \\
\text { conectados por um vetor. Regra } \\
\text { narrativa vetorial: "algo ou alguém } \\
\text { fazendo algo para o outro". }\end{array}$} & Processo de ação & $\begin{array}{l}\text { O vetor origina-se do "ator" em direção ao "objeto". } \\
\text { Nas representações, atores são os participantes mais } \\
\text { evidentes (tamanho, posicionamento na composição, } \\
\text { cor, contraste, foco, proeminência), que instigam o } \\
\text { processo transitivo. } \\
\text { Pode haver estrutura intransitiva (participante } \\
\text { representado único; ausência de vetor; ausência de } \\
\text { algo/alguém dirigindo-se a outro). }\end{array}$ \\
\hline & $\begin{array}{l}\text { Processo } \\
\text { reacional }\end{array}$ & $\begin{array}{l}\text { O vetor é formado pela direção do olhar de um ou } \\
\text { mais participante representado, partindo do "agente" } \\
\text { (reacter, humano ou animal) em direção ao } \\
\text { "fenômeno" (phenomena, participante representado } \\
\text { ou interativo). }\end{array}$ \\
\hline & $\begin{array}{l}\text { Processo } \\
\text { classificatório }\end{array}$ & $\begin{array}{l}\text { Tipo de relação entre os participantes (lugar na } \\
\text { ordem estática, rótulos, explanações), como } \\
\text { subordinação, v.g. }\end{array}$ \\
\hline & Processo analítico & $\begin{array}{l}\text { Relação entre todo (carrier) e parte (atributos } \\
\text { possessivos). }\end{array}$ \\
\hline & $\begin{array}{l}\text { Processo } \\
\text { simbólico }\end{array}$ & O que o participante significa ou é ( $v \cdot g$. fotografia). \\
\hline
\end{tabular}




\begin{tabular}{|c|c|c|}
\hline $\begin{array}{l}\text { Composição espacial do } \\
\text { significado (sistemas) } \\
\text { Significados representacionais e } \\
\text { interativos }\end{array}$ & $\begin{array}{l}\text { Valor da } \\
\text { informação } \\
\text { Lugar dos } \\
\text { elementos (topos) }\end{array}$ & $\begin{array}{l}\text { O dado (à esquerda) - informação já conhecida do } \\
\text { viewer/leitor. } \\
\text { O novo (à direita) - informação desconhecida pelo } \\
\text { viewer/leitor. }\end{array}$ \\
\hline \multirow{4}{*}{$\begin{array}{l}\text { Significados representacionais e } \\
\text { interativos }\end{array}$} & \multirow{2}{*}{$\begin{array}{l}\text { Lugar dos } \\
\text { elementos (topos) }\end{array}$} & $\begin{array}{l}\text { O real (abaixo) - específico, concreto, humano, } \\
\text { detalhado. } \\
\text { O ideal (acima) - generalizado, idealizado, } \\
\text { divinizado, ausente. }\end{array}$ \\
\hline & & $\begin{array}{l}\text { O centro - núcleo da informação, cerne, âmago, } \\
\text { sede. } \\
\text { A margem - dependência, subserviência, periferia. }\end{array}$ \\
\hline & $\begin{array}{l}\text { Saliência } \\
\text { Destaque, } \\
\text { proeminência. }\end{array}$ & $\begin{array}{l}\text { Primeiro e segundo planos; tamanho relativo; } \\
\text { contrastes e tonalidades; cores; formas. } \\
\text { Elementos (participantes e sintagmas } \\
\text { representacionais) atraem a atenção do viewer/leitor }\end{array}$ \\
\hline & $\begin{array}{l}\text { Enquadramento } \\
\text { Framing }\end{array}$ & $\begin{array}{l}\text { Presença ou ausência de molduras ou linhas } \\
\text { divisórias; conexão ou separação dos elementos. }\end{array}$ \\
\hline $\begin{array}{l}\text { Projeção (KRESS \& VAN } \\
\text { LEEUWEN, 1996, p. 212) }\end{array}$ & \multicolumn{2}{|c|}{$\begin{array}{l}\text { Composição e integração de códigos (tamanho, forma do foco, contraste de } \\
\text { tom e de cor, colocação no campo). } \\
\text { Resultado de uma complexa interação de códigos. } \\
\text { Os leitores da composição espacial são intuitivamente capazes de julgar o } \\
\text { peso de vários elementos da composição de acordo com o destaque dado } \\
\text { (FERRAZ, 2015, p. 412.) }\end{array}$} \\
\hline
\end{tabular}

Fonte: Elaborado pela autora, com base em Kress \& Van Leeuwen (1996) e Ferraz (2015).

A seguir, alcançamos o coração deste estudo, o Princípio de Integração dos Recursos Semióticos. Este princípio, esculpido no arcabouço teórico da Teoria Semiótica Social da Multimodalidade, prestar-se-á neste trabalho, analogamente, como supedâneo da nossa 
proposta de método integrado de análise, que se vale das seguintes categorias de análise: gênero e intertextualidade, da ADC de Fairclough; da TSSM de Kress \& Van Leeuwen, também o gênero e as categorias da Gramática Visual, para a análise de imagens; da Hermenêutica de Profundidade de John B. Thompson, os modos de operação da ideologia.

\subsubsection{Do Princípio de Integração dos Recursos Semióticos}

Cada modo semiótico (linguagem, imagem, som, gesto, v.g.) tem suas potencialidades e limitações na construção do sentido, conforme as funções que exercem nos textos que compõem, mas todos contribuem de forma integrada para a formação do significado global. Isto porque "textos multimodais são produtos composicionais do efeito combinado de todos os recursos usados para criá-los e interpretá-los”. (BALDRY; THIBAULT, 2006, p. 18). Um texto multimodal "deve ser lido em conjunção com todos os outros modos semióticos desse texto" (KRESS; VAN LEEUWEN, 1996, p. 374).

Entendemos que as consequências da aplicação do Princípio de Integração dos Recursos Semióticos representam uma guinada na investigação das condições de construção semiótica dos significados na linguagem verbal (escrita e oral) e não verbal, ou seja, os "recursos semióticos dos diferentes sistemas organizados e instanciados em textos multimodais" (VIEIRA; SILVESTRE, 2015, p. 18).

As potencialidades que traz a observação deste princípio para a análise textual, discursiva e social são imensuráveis. Apenas para ilustrar perfunctória, mas didaticamente, como se vem largamente empregando nos textos midiáticos a integração dos recursos semióticos para a construção de sentidos ideologicamente marcados, apresentamos algumas capas do Jornal da Câmara, nos quais a integração dos modos escrito e imagético mostra dois movimentos opostos na construção do sentido: ou os modos se unem para reforçarem-se mutuamente, ou, contrario sensu, mitigam os significados de um ou outro. 
Figura 16 - Capa do Jornal da Câmara, de 19 de junho de 2013
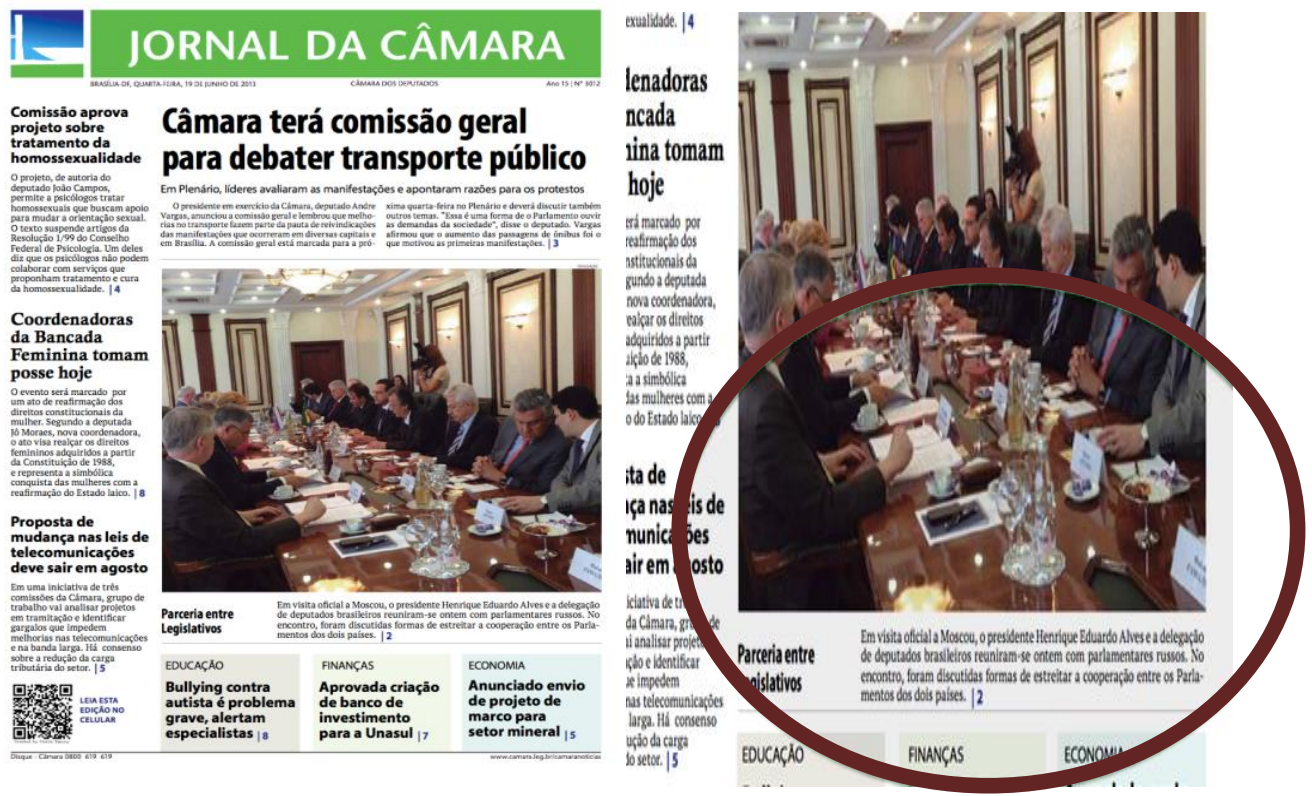

Fonte: Página eletrônica Câmara dos Deputados.

$\mathrm{Na}$ capa acima reproduzida, a manchete "Câmara terá comissão geral para debater transporte público”, busca mostrar uma atitude responsiva da Câmara dos Deputados ao apelo das grandiloquentes manifestações populares havidas dois dias antes no Congresso Nacional, deflagradas por causa do aumento das passagens de ônibus em São Paulo. A Casa, reunida em Comissão, estaria debatendo o tema. De fato, a imensa fotografia central da capa expõe o então Presidente da Casa e vários outros Deputados reunidos em intenso trabalho. Contudo, somente com a leitura acurada da legenda da foto, em letras minúsculas, pode-se constatar que, em verdade, o Presidente sequer estava no País: "Em visita oficial a Moscou, o presidente Henrique Eduardo Alves e a delegação de deputados brasileiros reuniram-se ontem com parlamentares russos." Neste caso, buscou-se um efeito de integração dos recursos semióticos dos modos escrito e imagético em diferentes clusters para criar uma ilusão de que a Casa estaria atendendo ao clamor popular, ludíbrio que somente poderia ser desfeito se fosse lida a legenda ou a matéria interna.

Esta outra capa, abaixo, foi publicada quando da polêmica discussão da redução da maioridade penal no Brasil em 2015, a que a Presidência da Casa era manifestamente favorável, apesar de um forte movimento da opinião pública em sentido contrário. A figura de uma pessoa encapuzada, com spray de tinta na mão, desenhando em uma parede, parece 
querer representar um jovem deliquente, pixador de paredes. Na manchete maior, a menção à volta da PEC da Maioridade à pauta. Na manchete menor, notícias sobre o crime de terrorismo (ou o projeto de lei sobre o terrorismo). Em verdade, nenhuma das manchetes se relaciona à imagem, em cuja legenda se lê: "A Secretaria da Mulher promoveu ontem evento pelos nove anos da Lei Maria da Penha: a grafiteira carioca Pamela Castro produziu ao vivo, na área das Palmeiras Imperiais, atrás do Congresso, dois painéis (...)”.

Figura 17 - Capa do Jornal da Câmara, de 11 de agosto de 2015

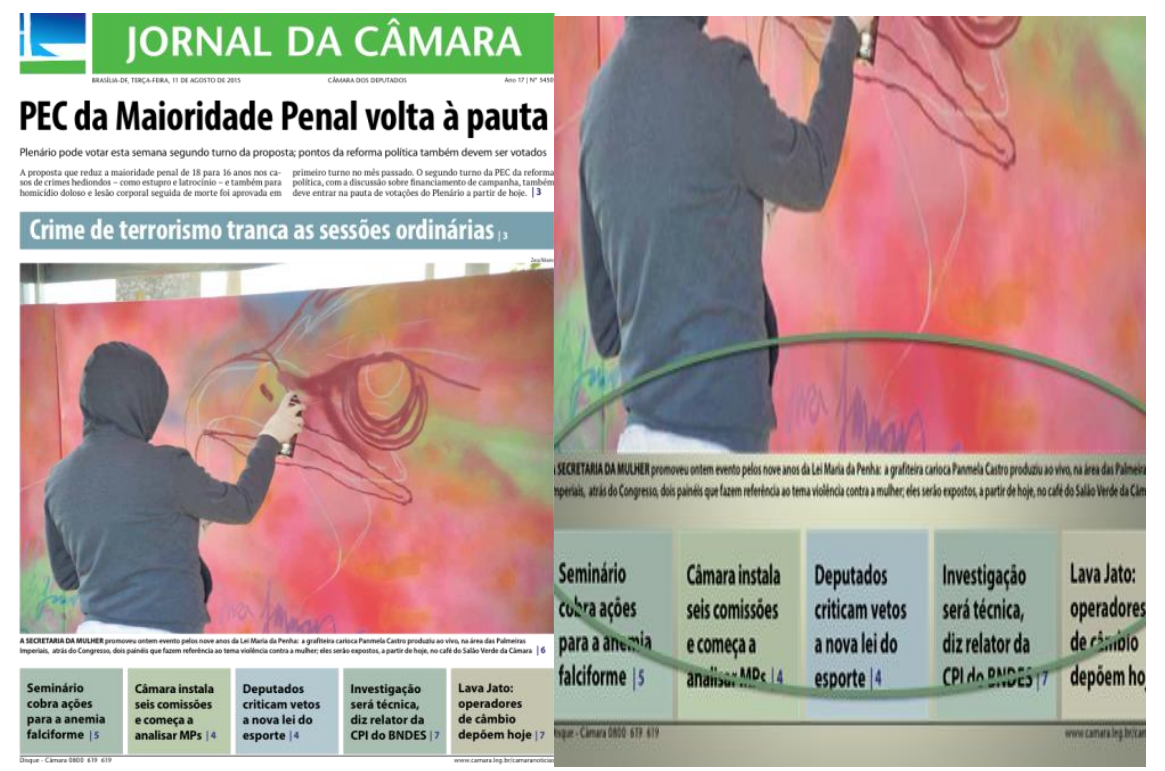

Fonte: Página eletrônica Câmara dos Deputados.

Também no contexto da discussão sobre a redução da maioridade penal, apresentaramse capas em que o retrato do Presidente da Câmara dos Deputados mostra-o acompanhado de crianças felizes, de mãos dadas, vestidas de anjo, etc. Mas também se faz acompanhar da imagem de jovens deliquentes em brigas violentas nos estádios de futebol. O propósito, na construção do sentido, desponta translúcido: retrata-se a Casa defensora das crianças e de seus direitos, por um lado, mas austera e inclemente (vide a expressão facial do Presidente) diante de jovens bandidos. De fato, o projeto sobre a redução da maioridade penal, depois de muito debate e alguns estratagemas regimentais, foi aprovado. 
Figura 18 - Capas do Jornal da Câmara, dos dias 10/6, 12/6 e 29/6 de 2015

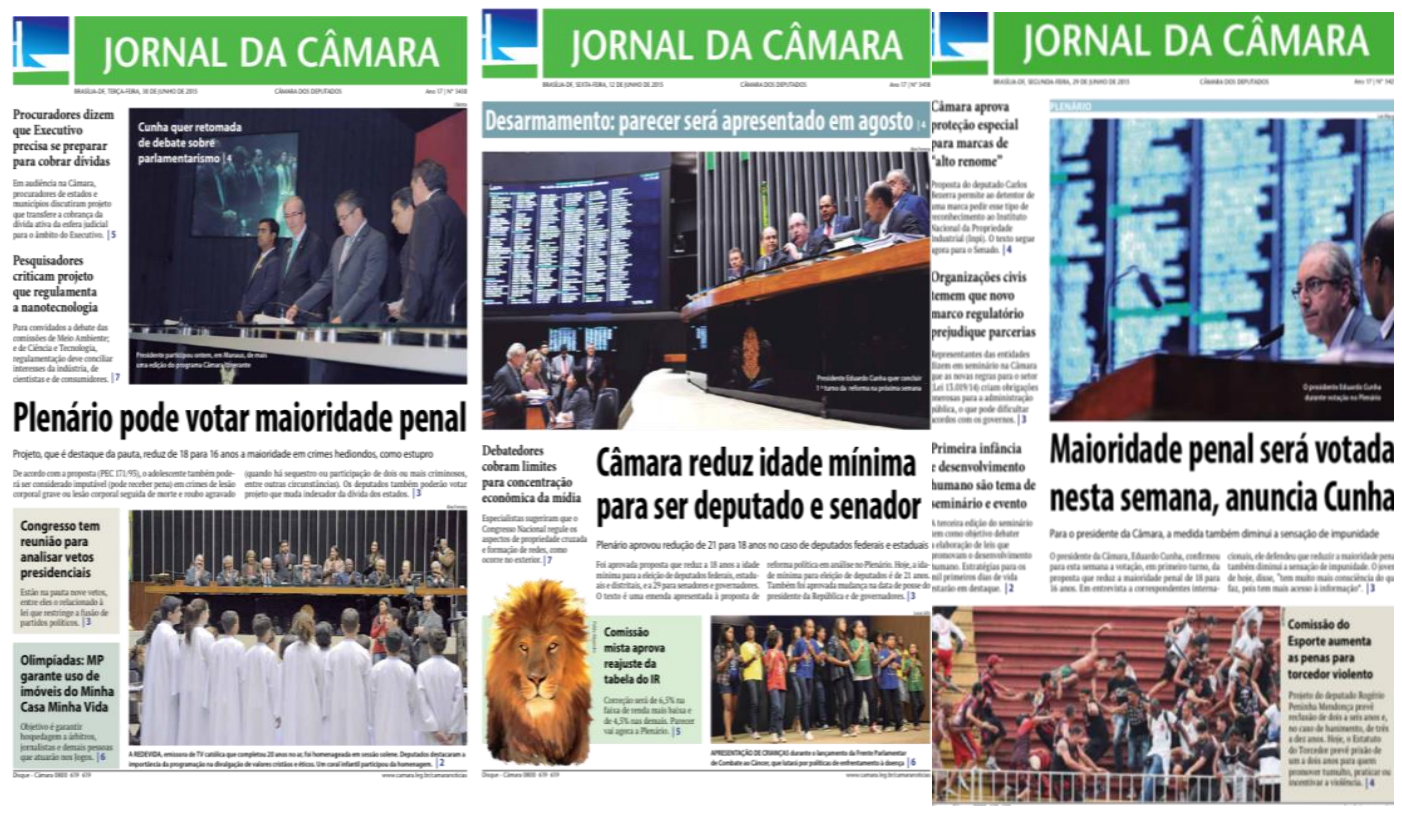

Fonte: Página eletrônica Câmara dos Deputados.

As capas do jornal aqui reproduzidas apenas ilustram, ligeiramente, a relevância da aplicação do Princípio de Integração dos Recursos Semióticos para a análise discursiva crítica e multimodal. Por tal razão, reiteramos, este princípio norteia toda a análise formal-discursiva.

Na seção seguinte, o último vértice da triangulação teórica deste estudo, cujo enfoque na interpretação discursivo-ideológica complementa a figuração do suporte doutrinário de que necessitamos para a análise de gênero pretendida.

\subsection{A HERMENÊUTICA DE PROFUNDIDADE DE JOHN B. THOMPSON}

Inserto no contexto da Teoria Social Crítica, a elaboração doutrinária de John B. Thompson focaliza a "era dos meios de comunicação de massa" e tem como princípio o entendimento de que as formas simbólicas permeiam o mundo social, e o fazem de modo crescente e generalizado. Em sua persecução, mira o papel e a natureza da ideologia e da mediação da cultura nesse processo social que se inicia a partir da era moderna. 
Thompson (1995) sintetiza, com esta asserção, sua noção crítica de ideologia, a que anuímos: "Ideologia é o sentido a serviço do poder". Assim, estudar ideologia é entender as maneiras pelas quais as formas simbólicas são usadas para o estabelecimento e para a manutenção de relações de dominação. O estudo insere-se, portanto, no âmbito maior da cultura, em que tangencia a argumentação de Fairclough (2003) de que existe uma relação dialética entre estrutura social e discurso. Thompson (1995) enfatiza "o processo geral através do qual a transmissão das formas simbólicas se tornou sempre mais mediada pelos aparatos técnicos e institucionais das indústrias da mídia", o que ele entende como mediação da cultura. Essas transformações nos contextos sociais, pelo desenvolvimento da mass media, implicam mudança nas formas simbólicas, em seu modo de produção, transmissão e recepção, operações significativamente ampliadas na cultura moderna.

A Hermenêutica de Profundidade (HP) de Thompson é método de análise que se estende além da investigação sócio-histórica, para ser empregado no estudo das formas simbólicas em geral em análise da ideologia, em particular. Prevê três fases ou procedimentos:

i) Análise sócio-histórica, que contextualiza o evento discursivo a ser analisado e enfoca as condições de produção, circulação e recepção das formas simbólicas, em que se investigam as situações espaço-temporais, os campos de interação, as instituições sociais, a estrutura social e os meios técnicos de transmissão.

ii) Análise formal-discursiva, em que se procede à análise da semiótica, da conversação, dos aspectos sintáticos, da narrativa e da argumentação. Nesta fase, inserem-se como categorias de análise os modos de operação da ideologia. "Essa fase de análise, embora perfeitamente legítima, pode se tornar enganadora quando é separada do referencial da hermenêutica de profundidade e concebida como um fim em si mesma" (THOMPSON, 1995, P. 34).

iii) Interpretação (ou reinterpretação), em que o analista faz uma síntese das fases anteriores e constrói um possível significado. Coadunamos o nosso entendimento ao de Thompson em relação à ideia de significado possível, cientes de que outros poderiam ser obtidos no processo de interpretação das formas simbólicas.

Ao apor ao método hermenêutico um objetivo crítico, Thompson (1995, p. 35) elabora 
uma versão do método, a qual denomina Interpretação da Ideologia: "Interpretar a ideologia é explicitar a conexão entre o sentido mobilizado pelas formas simbólicas e as relações de dominação que esse sentido mantém”. No exercício hermenêutico a que nos entregamos neste trabalho, propomo-nos a descortinar como o sentido serve para estabelecer ou sustentar relações de dominação. Para o autor, este é o cerne do estudo da ideologia, para o qual destaca cinco modus operandi, resumidos no quadro abaixo, trasladado de Paiva (2015, p. 42):

Quadro 4-Modos de Operação da Ideologia (THOMPSON, 2002)

\begin{tabular}{|c|c|c|c|}
\hline Modos gerais & Natureza & $\begin{array}{l}\text { Estratégias típicas de construção } \\
\text { simbólica }\end{array}$ & Expressão \\
\hline \multirow[t]{3}{*}{ Legitimação } & \multirow{3}{*}{$\begin{array}{l}\text { Representação das relações } \\
\text { de dominação como justas e } \\
\text { dignas }\end{array}$} & Racionalização & Cadeia de raciocínio \\
\hline & & Universalização & $\begin{array}{l}\text { Acordos } \\
\text { institucionais }\end{array}$ \\
\hline & & Narrativização & $\begin{array}{l}\text { Tradição eterna e } \\
\text { aceitável }\end{array}$ \\
\hline \multirow[t]{3}{*}{ Dissimulação } & \multirow[t]{3}{*}{$\begin{array}{l}\text { Ocultação/negação } \\
\text { relações de dominação }\end{array}$} & Deslocamento & $\begin{array}{l}\text { Transferência de } \\
\text { termos }\end{array}$ \\
\hline & & Eufemização & $\begin{array}{l}\text { Despertamento da } \\
\text { valoração positiva }\end{array}$ \\
\hline & & $\begin{array}{l}\text { Tropo (sinédoque, metonímia, } \\
\text { metáfora) }\end{array}$ & $\begin{array}{l}\text { Uso figurativo da } \\
\text { linguagem }\end{array}$ \\
\hline \multirow[t]{2}{*}{ Unificação } & \multirow[t]{2}{*}{$\begin{array}{l}\text { Construção de uma } \\
\text { identidade coletiva }\end{array}$} & Estandardização/Padronização & $\begin{array}{l}\text { Tomada de um } \\
\text { referencial padrão }\end{array}$ \\
\hline & & Simbolização da unidade & $\begin{array}{l}\text { Símbolos de } \\
\text { identidade }\end{array}$ \\
\hline \multirow[t]{2}{*}{ Fragmentação } & \multirow{2}{*}{$\begin{array}{l}\text { Segmentação de indivíduos } \\
\text { e/ou grupos }\end{array}$} & Diferenciação & Ênfase nas distinções \\
\hline & & Expurgo do outro & $\begin{array}{l}\text { Construção de um } \\
\text { inimigo }\end{array}$ \\
\hline \multirow[t]{3}{*}{ Reificação } & \multirow{3}{*}{$\begin{array}{l}\text { Retratação da } \\
\text { atemporalidade de situações } \\
\text { históricas }\end{array}$} & Naturalização & $\begin{array}{l}\text { Eliminação do caráter } \\
\text { sócio-histórico }\end{array}$ \\
\hline & & Eternalização & $\begin{array}{l}\text { Fenômenos } \\
\text { permanentes }\end{array}$ \\
\hline & & Nominalização/Passivização & $\begin{array}{l}\text { Apagamento } \\
\text { atores e ação }\end{array}$ \\
\hline
\end{tabular}

Fonte: PAIVA, 2015, p. 41. 
É preciso dizer que da totalidade dos modos de operação ideológica destacam-se alguns no procedimento analítico, ou seja, nem todos foram identificados e descritos. Apenas aqueles que se nos apresentam mais relevantes para o entendimento de determinada estratégia discursiva, em determinado excerto do corpus, são avocados e integrados à análise discursiva crítica e multimodal.

Para alcançar o entendimento, ainda que parcial, das relações de poder subjacentes ao produto midiático do Parlamento, aliamos ao método thompsoniano - e com a autorização expressa de Thompson (1995, p. 361), que defende a cooperação metodológica - outros procedimentos de análise. O capítulo seguinte dedica-se a elucidá-los. 


\section{CAPÍTULO 3}

\section{PROPOSTA DE MÉTODO ANALÍTICO INTEGRADO}

\subsection{APRESENTAÇÃO DO CORPUS}

Escolhemos este ponto do trabalho para apresentar o corpus porque é a natureza multimodal deste que nos direciona à escolha da metodologia de análise, delineada na próxima seção. A transdiciplinaridade e a integração de teorias e métodos proposta para este estudo justificam-se, antes de tudo, pelo hibridismo de gêneros que caracteriza as novas práticas discursivas - e percebido a priori no evento discursivo que ora se analisa linguística e criticamente, no âmbito da comunicação política realizada na e pela Câmara dos Deputados do Brasil. Sobre isso, eis o dizer de Fairclough (2003, p. 46):

[...] uma área da vida social em que o hibridismo [de gênero] tem recebido atenção particularmente intensa é a mídia — os textos de comunicação de massa podem ser vistos como operadores de ofuscamento de fronteiras de várias maneiras: fato e ficção, notícias e entretenimento, drama e documentário [...].

Kress e Van Leeuwen (2006 [1996]) propugnam que o uso da linguagem multimodal, híbrida, que lida com variados recursos semióticos num texto, tende a tornar-se dominante no contexto das vertiginosas mudanças havidas com o estabelecimento da mídia digital - e a conseguinte convergência das mídias (MARTIN-BARBERO, 2004). Embora não estejamos lidando com textos digitais, ao tratar do discurso produzido e distribuído pela mídia institucional, estamos lidando com um gênero discursivo complexo de per si, pois que neste se imbricam, a um só tempo, questões atinentes ao discurso midiático, ao discurso político, ao discurso cultural e ao discurso público-institucional de uma das Casas do Poder Legislativo do Brasil, distribuídos por seus diferentes media de comunicação (VIEIRA; SILVESTRE, 2015, p. 24), os quais também seguem e testificam as tendências da convergência digital no mundo globalizado do Novo Capitalismo (FAIRCLOUGH, 2003), em interatividade virtual e não virtual.

Assim, tomam-se como objeto de análise elementos dos recursos semióticos empregados para a construção da exposição cultural Parlamento e Democracia e de seu 
prospecto. A exposição foi dirigida mormente aos Parlamentares recém-empossados para a 55 $5^{\text {a }}$ Legislatura (2015-2018), mas exposta a todos os que circularam pelos corredores de acesso ao plenário e divulgada amplamente pelos meios de comunicação da abrangente e poderosa mídia parlamentar.

\subsubsection{A exposição Parlamento e Democracia e o seu prospecto}

Por meio da modalidade escrita, um texto extraído do próprio corpus (multimodal) o define e descreve como "exposição" ou "mostra" cultural e histórica, conforme grifamos no texto abaixo:

A exposicão Parlamento e Democracia, que marca o início dos trabalhos da $55^{a}$ Legislatura em $1^{\circ}$ de fevereiro de 2015 , apresenta a evolução da representação popular no mundo ao longo dos séculos, com ilustrações e textos de filósofos e pensadores das diversas épocas. A mostra também lembra a história da Câmara dos Deputados desde a Assembleia Constituinte de 1823, numa homenagem aos brasileiros que contribuíram para construir uma naçãocontinente e consolidar as instituições democráticas.

O folder - prospecto impresso de pequeno porte, com conteúdo informativo ou publicitário - , objeto também componente de nossa análise, foi produzido pela Secretaria de Comunicação (Secom) da Câmara dos Deputados do Brasil, sob a curatoria de Ricardo Oriá, com o emprego de textos na modalidade escrita e visual, e distribuído na exposição intitulada Parlamento e Democracia, que permaneceu de $1^{\circ}$ de fevereiro a 8 de abril de 2015 no corredor de acesso ao Plenário Ulysses Guimarães, com o objetivo — este é, pelo menos, um dos objetivos declarados, não o propósito maior por nós reconhecido — de dar boas-vindas aos então novos Deputados componentes da $55^{\mathrm{a}}$ Legislatura.

Mas é preciso ressaltar que o prospecto da exposição não se dirige aos Deputados, mas ao visitante em geral, e apresenta texto exordial sutilmente diferente do texto introdutório da 
exposição, dirigido aos Parlamentares. $\mathrm{Na}$ análise discursiva e multimodal, busca-se o porquê dessa discrepância.

Figura 19 - Capa do folder da exposição Parlamento e Democracia

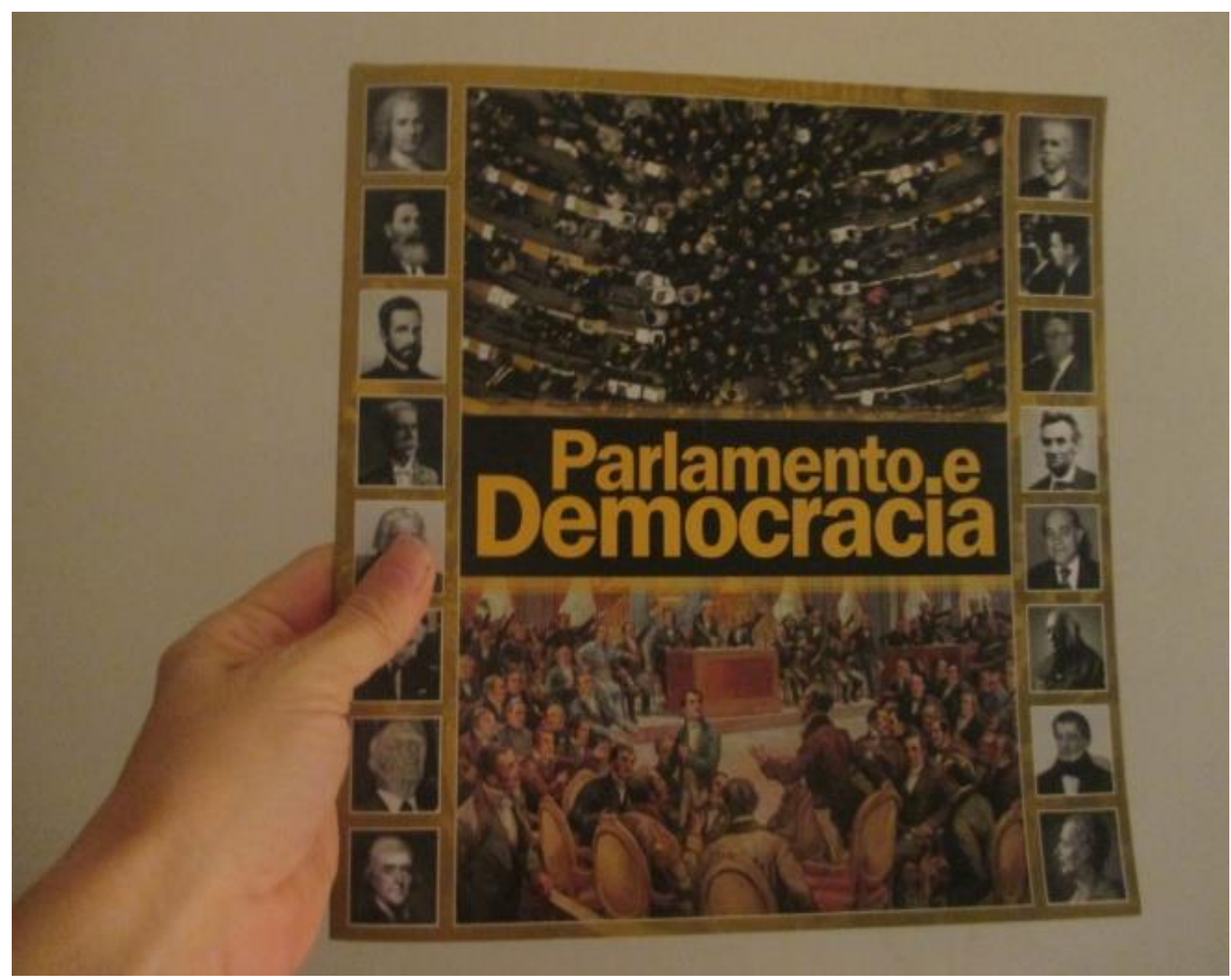

Fonte: Acervo da Câmara dos Deputados. 
Figura 20 - Parte interna do folder da exposição Parlamento e Democracia

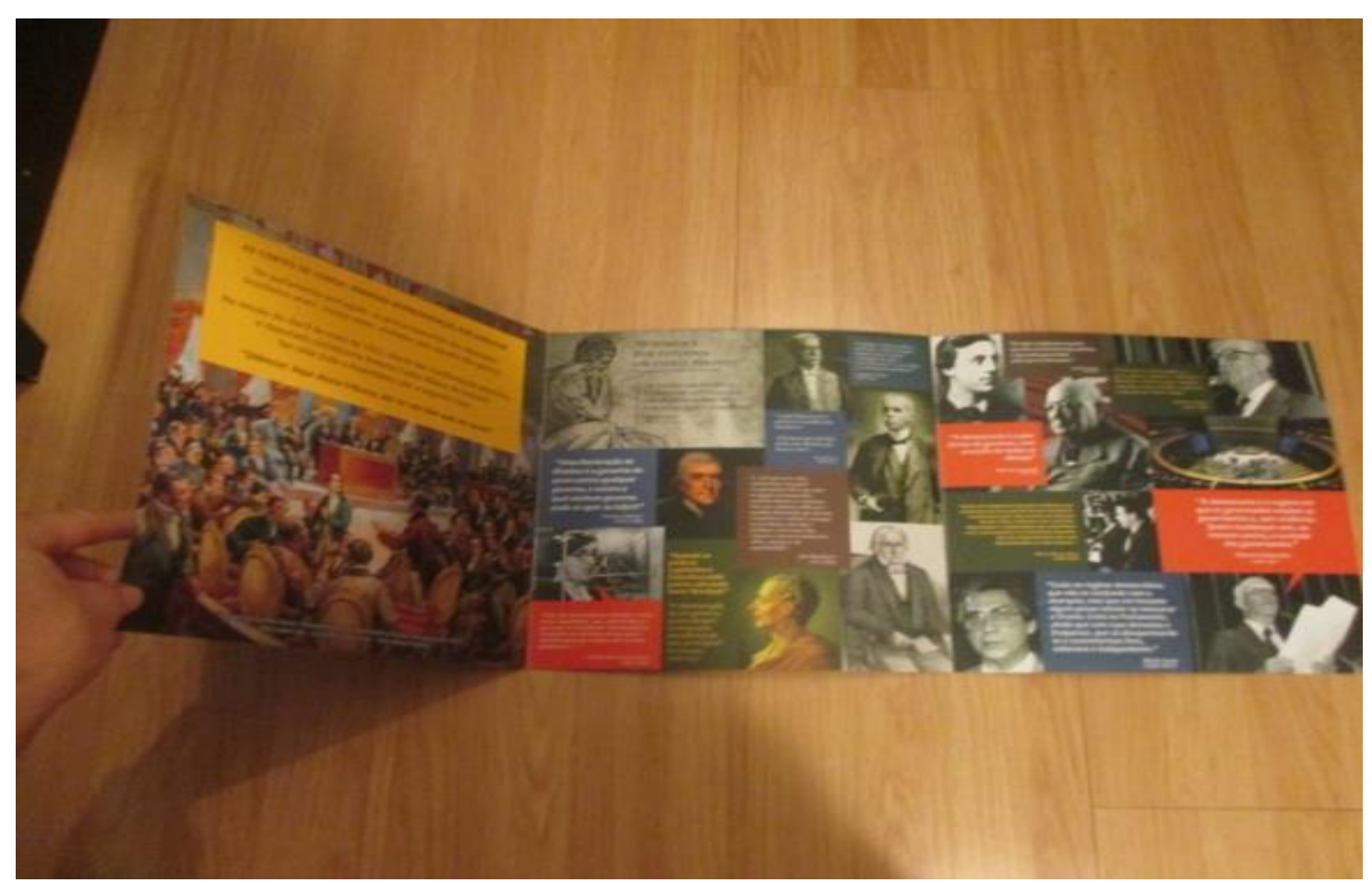

Fonte: Acervo da Câmara dos Deputados.

Imperioso assinalar que a convergência das mídias, sobre a qual dissertamos, impõe mudanças na linguagem, não só no âmbito da produção, mas também da distribuição dos textos (prática discursiva), os quais se submetem a recontextualizações ou delocações (FAIRCLOUGH, 2006), fenômenos que Iedema (2003) chama de ressemiotização do discurso (alterações na linguagem provocadas pela mudança dos media de difusão, que resultam em combinações textuais híbridas) e Poster (1996 apud VIEIRA; SILVESTRE, 2015, p. 24) chama de reconfiguração:

[...] a linguagem, para se reconfigurar em quaisquer práticas discursivas, deve refletir as mudanças decorrentes dos usos dos media de comunicação, que contribuem para estabelecer, divulgar e reproduzir ideologias, capazes de sustentar ou de manter desigualdades e injustiças sociais, além de revelar as relações de poder presentes no discurso.

Tal fenômeno mostra-se tão relevante para a análise linguística que, na visão de Fairclough (2006), a recontextualização seria a principal fonte de mudança da linguagem, que 
se concretizaria em hibridismos intertextuais e interdiscursivos (FAIRCLOUGH, 2001, p. 126).

No prospecto cujos significados semióticos escrutinamos, notamos indícios desses fenômenos sociolinguísticos, como a hibridização de gênero discursivo e textual (discurso político em exposição de arte) e a colonização da ordem do discurso, ou seja, a penetração do discurso publicitário na ordem do discurso político, e de suas consequências na composição textual (no sentido da TSSM) dos produtos de mídia da Câmara dos Deputados, de cunho prevalentemente político. 
Figura 21 - Detalhes da página interna do folder da exposição Parlamento e Democracia

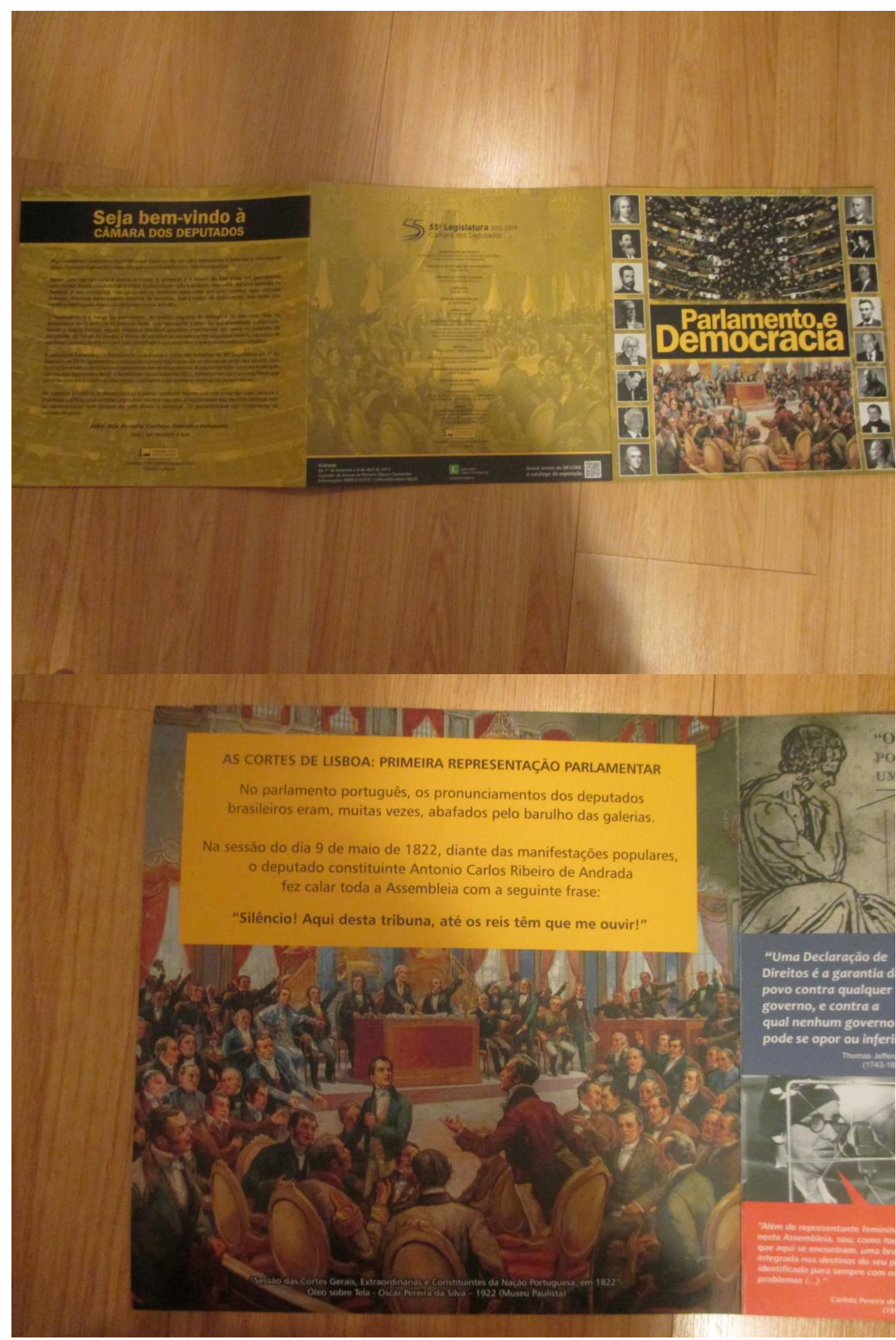

Fonte: Acervo da Câmara dos Deputados do Brasil 
Optamos por estender a análise ao prospecto porque nele estão selecionados, pelo próprio produtor dos signos, os textos e imagens que aquele considera representativos de toda a exposição. A profusão e abundância dos recursos semióticos não nos permite analisar a exposição em sua totalidade, não com a minudência que pretendemos. E mesmo do folder selecionamos apenas alguns textos e imagens que se nos mostram significativos ao objetivo do estudo.

Estes textos e imagens, entretanto, estão sempre considerados em relação ao todo, como compósitos da exposição Parlamento e Democracia, previamente apresentada no primeiro capítulo, agora reapresentada com mais detalhamento, nas fotos seguintes.

Figura 22 - Fotos da exposição Parlamento e Democracia
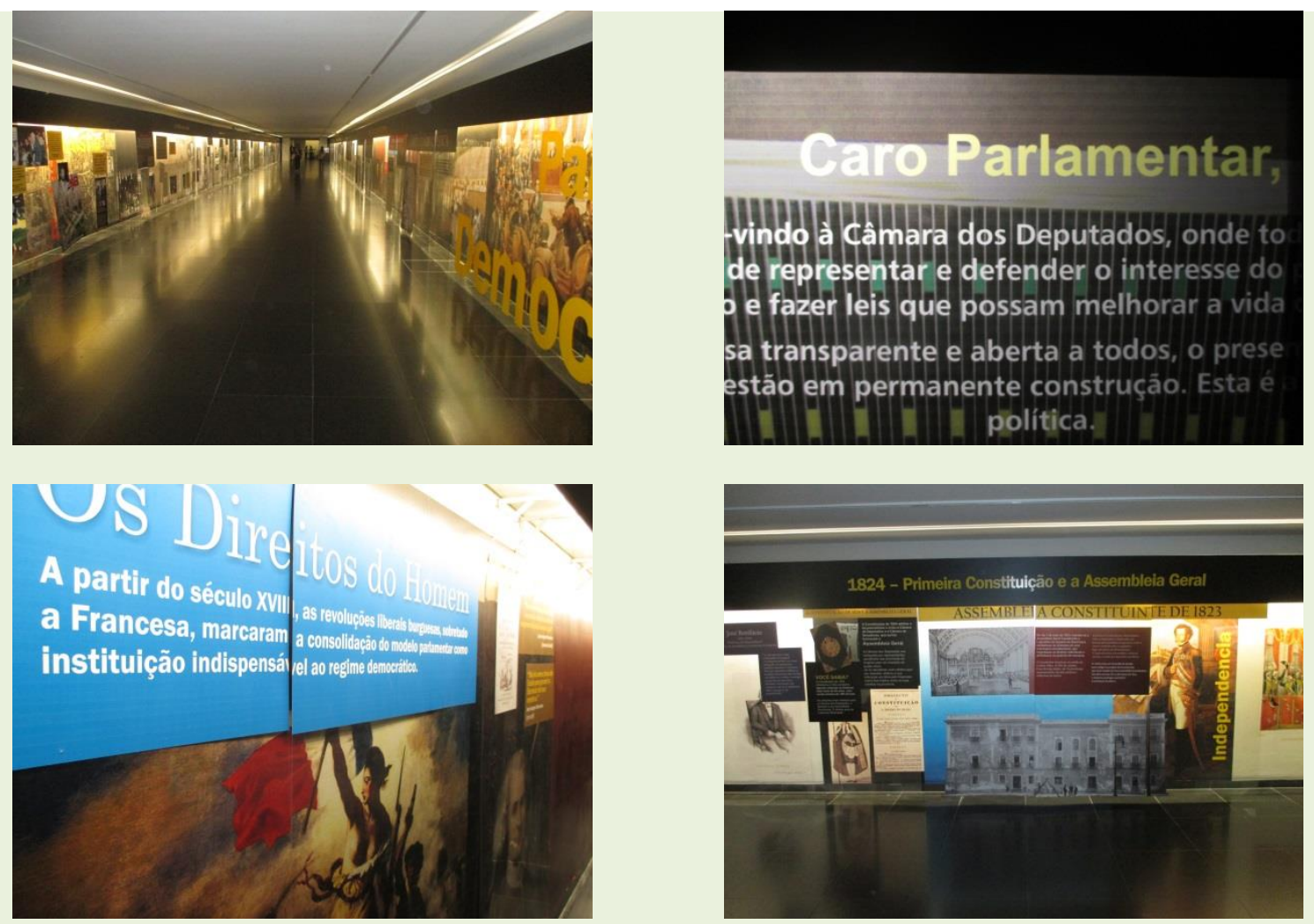

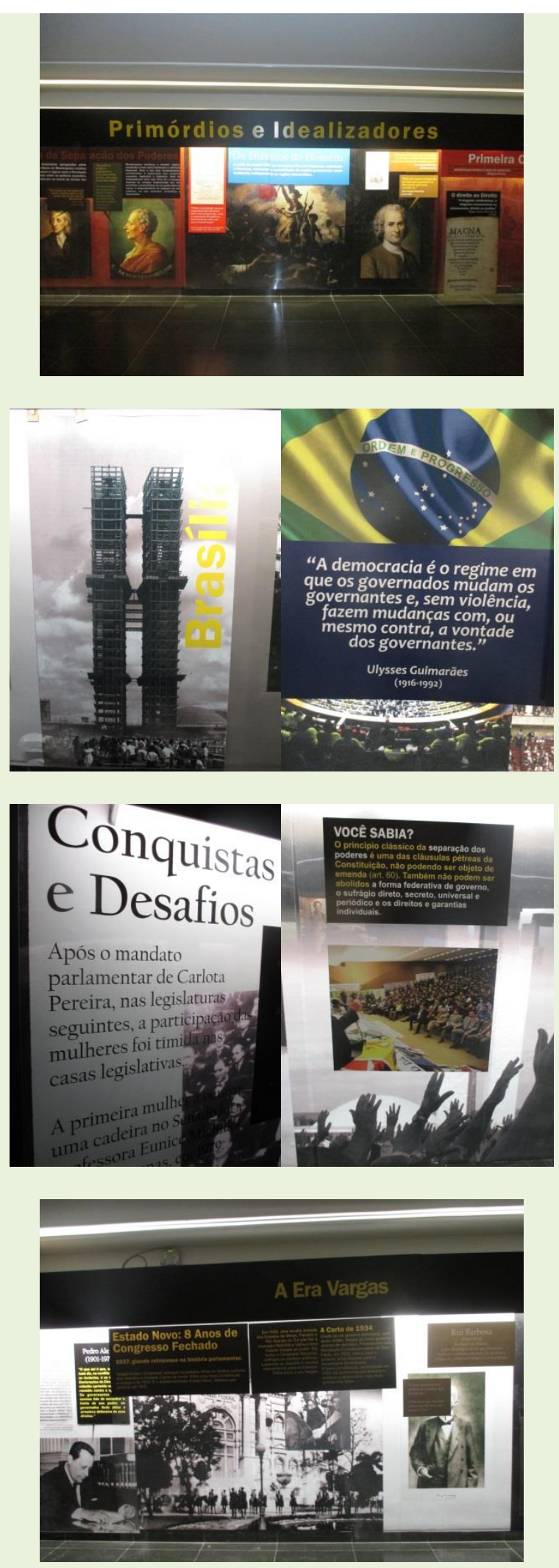

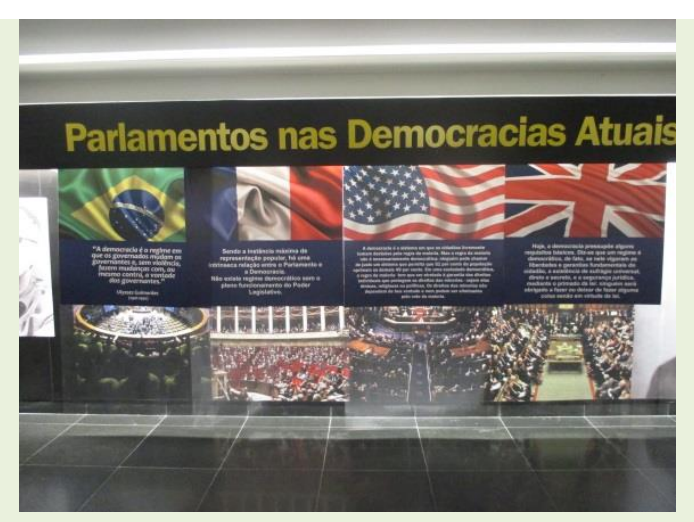

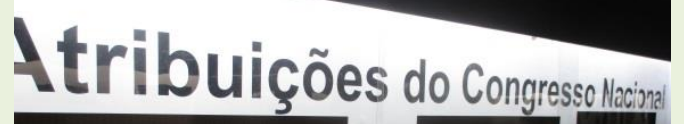
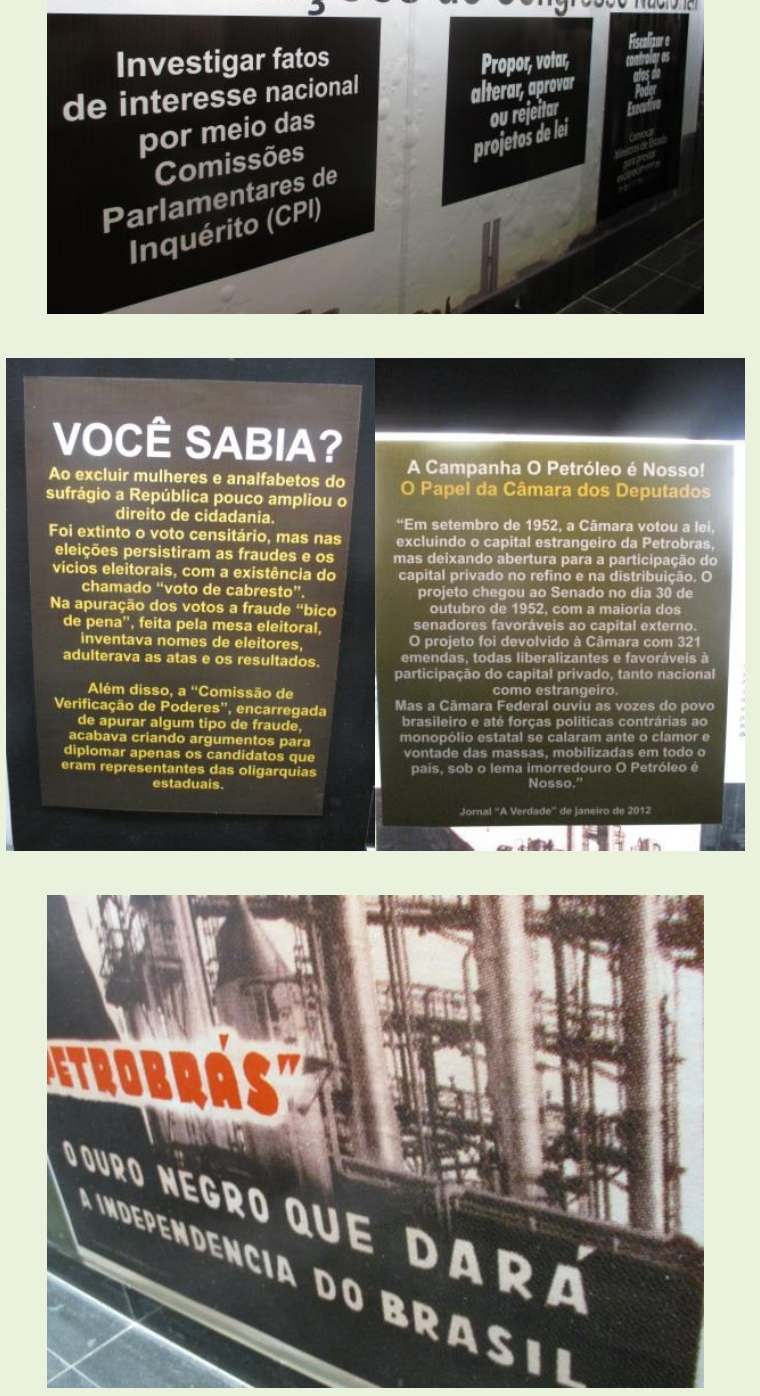

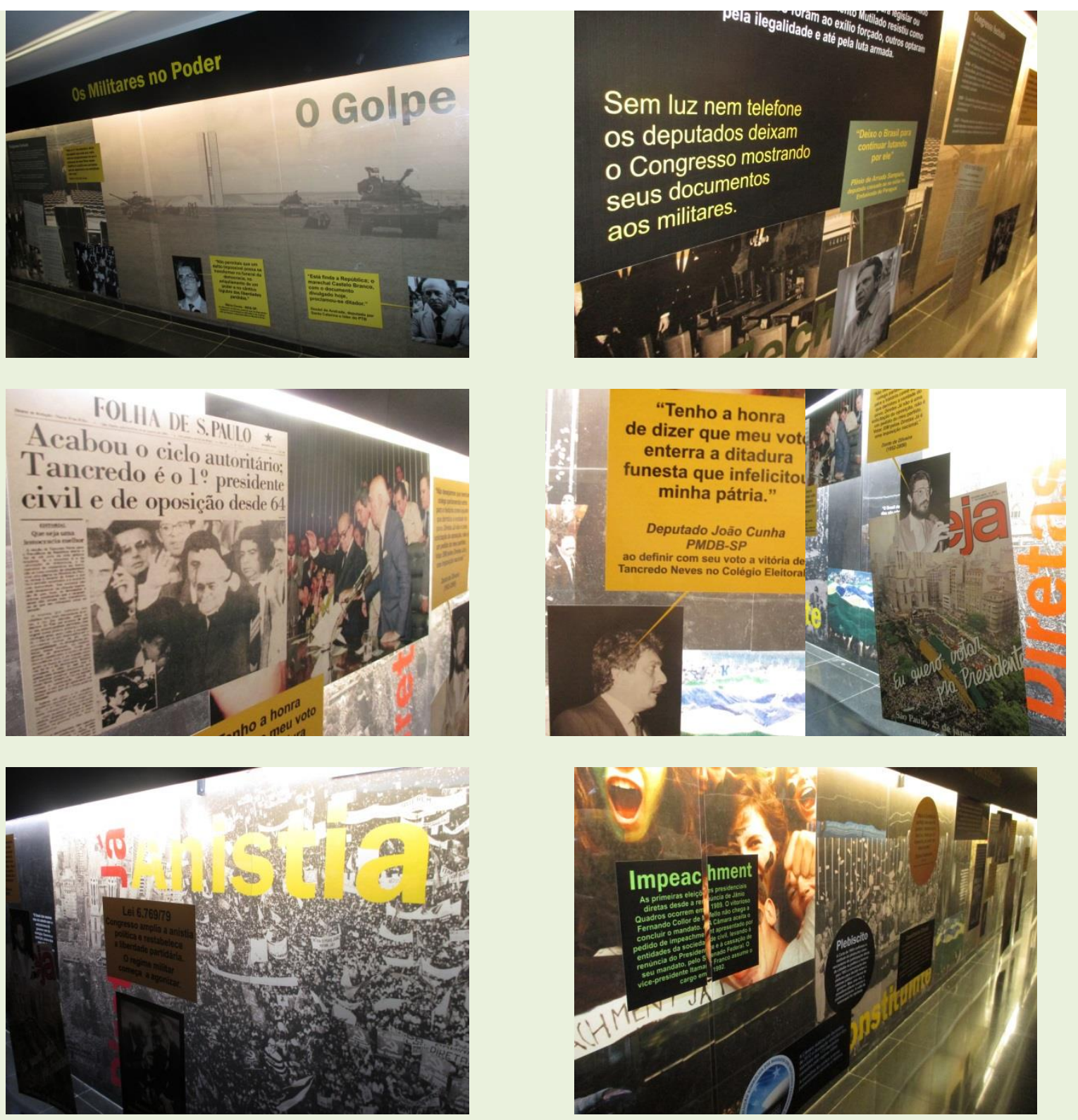

Fonte: Acervo fotográfico pessoal da autora (fotos da exposição Parlamento e Democracia).

A exposição histórica foi dividida em oito partes principais:

I. Cortes de Lisboa: Primeira Representação Parlamentar do Brasil

II. $\quad 1824$ - Primeira Constituição e a Assembleia-Geral

III. O Parlamento e a Abolição da Escravatura

IV. A República Velha e o Congresso Nacional

V. A Era Vargas 
VI. Os Militares no Poder

VII. A Nova República e a Assembleia Nacional Constituinte

A finalidade geral ou propósito declarado, nós os destacamos no texto seguinte, divulgado também no site da Câmara dos Deputados ${ }^{16}$ :

\section{Parlamento e Democracia}

Novos deputados são recebidos com exposicão que mostra a importância da instituição parlamentar no Ocidente e os momentos mais significativos do Legislativo no Brasil. A mostra Parlamento e Democracia ficará aberta ao público de 2 de fevereiro a 8 de abril, inclusive aos sábados, domingos e feriados.

A exposição foca a evolução da representacãa popular no mundo e a história do Parlamento no Brasil, desde os seus primórdios, quando deputados brasileiros foram representados nas Cortes de Lisboa (1821), passando pela instalação da primeira Assembleia Constituinte (1823), até a atualidade, com destaque para os momentos em que o Poder Legislativo teve papel relevante na vida política nacional. Imagens e textos registram momentos históricos do Legislativo, como o debate parlamentar sobre o fim do trabalho escravo, que precedeu a sanção da Lei Áurea (1888); o processo de redemocratização do país, com a votação da Lei da Anistia (1979); a luta pelo retorno das eleições diretas (1983-1984); e a mobilização da sociedade civil na Assembleia Constituinte (1987-1988).

Em síntese, podem-se elencar, como objetivos declarados, os seguintes:

i) dar boas-vindas aos novos deputados;

ii) mostrar a importância da instituição parlamentar no Ocidente;

iii) mostrar os momentos significativos do Legislativo no Brasil;

iv) focalizar a evolução da representação popular no mundo e a história do Parlamento no Brasil, desde seus primórdios;

v) homenagear os brasileiros que contribuíram para construir a nação e consolidar as instituições democráticas.

\footnotetext{
${ }^{16}$ Disponível em: <http://www2.camara.leg.br/participe/cultura-na-camara/noticias/parlamento-e-democracia>.
} Acesso em: 27 set. 2015. 
Este rol de propósitos declarados da exposição histórica mostra-se fulcral para a análise do gênero do discurso que levamos a cabo neste estudo, pois adiante se analisam, entre outros elementos do gênero, segundo Kress (1989), as finalidades ou propósitos reconhecidos pelos produtores do evento social.

Feita a apresentação do corpus, apresentamos, na seção seguinte, a nossa proposta de método analítico integrado.

\subsection{UMA PROPOSTA DE MÉTODO ANALÍTICO INTEGRADO}

Ao tratar de ideologia, cultura e midiatização, o sociólogo John B. Thompson (1995, p. 361) propugna a cooperação metodológica, ao tempo em que propõe três etapas para a Hermenêutica de Profundidade (HP): a análise sócio-histórica, a análise formal-discursiva, a interpretação e reinterpretação. Como a hermenêutica dos discursos políticos tem como enfoque as estratégias discursivas tendentes à operacionalização de propósitos ideológicos (THOMPSON, 1995, p. 81), as etapas de análise propostas por Thompson - que não são estanques, mas sim integradas e dialéticas — servem-nos de parâmetro para a organização dos capítulos deste estudo de forma global: iniciou-se pela análise sócio-histórica, com o entendimento de fenômenos como o a multimodalidade e a convergência das mídias. Mas também ali se delinearam alguns aspectos situacionais. A partir do próximo capítulo, iniciarse-á a análise formal-discursiva e, num movimento contínuo, proceder-se-á à interpretação e reinterpretação dos textos selecionados, que teraá como foco o delineamento do gênero do discurso dos textos.

Os caminhos propostos por John B. Thompson seguem na mesma direção dos indicados por Norman Fairclough. Este linguista (2001, p. 89) preconiza que o discurso deve ser compreendido e analisado em suas três dimensões - prática social, prática discursiva e prática textual, o que permite uma análise dialética do ponto de vista social (explicação), discursivo (interpretação) e textual (descrição). Assim, parte-se da análise contextual para a análise textual, um movimento dedutivo que também não se dá de forma unidirecional e linear, mas ainda assim se coaduna com os procedimentos metodológicos da análise social de Thompson. Por isso, podemos dizer que também nos esteiamos nas dimensões da Teoria 
Tridimensional do Discurso como uma das bases metodológicas, até porque se evocam os preceitos desta teoria em todo o trabalho.

Impende notar que de abordagens multidisciplinares deriva o próprio arcabouço metodológico da Análise Crítica de Discurso (ADC), em que nos esteiamos e segundo a qual "questões sociais e políticas chave têm um caráter parcialmente linguístico-discursivo" (FAIRCLOUGH; WODAK, 1997, p. 271), por isso trabalha também com categorias sociológicas de análise.

Tanto a Teoria Tridimensional do Discurso, proposta por Fairclough, quanto o método da HP, de Thompson, servem de suporte à organização global da pesquisa e sua repartição em capítulos e seções. Ambos os métodos podem ser integrados, embora, de per si, cada um dos métodos já se bastaria. Contudo, podem jungir-se profícua e incolumemente, para uma exegese rica e seminal na perquirição dos matizes ideológicos subjacentes ao discurso do Parlamento.

Vale lembrar que também se autoproclama interdisciplinar a Teoria Semiótica Social Multimodal (TSSM), segundo lições de Van Leeuwen (2005), teoria que completa nossa tríade teórico-doutrinária. Gunther Kress (1989, p. 20) aduz que a Semiótica Social concebe a linguagem como prática de produção de significados, e elege o texto como unidade de análise, sendo o texto "duplamente determinado pelos significados sociais dos discursos que nele figuram e pelas formas, significados e restrições de determinado gênero". Seu método e categorias de análise também se evocam, pontualmente, quando demandados pelo corpus.

Assim, embora tenhamos elegido duas bases metodológicas para a organização global do estudo, entendemos que todo o arcabouço teórico-metodológico nos autoriza o principiar da análise do contexto sócio-histórico: a prática social, na ADC, os significados sociais e situacionais, na TSSM, e o contexto sócio-histórico, na HP. Este passo, já o demos no Capítulo 1, ao descrever o panorama sócio-histórico e situacional, que identificou alterações em curso na ordem do discurso em âmbito institucional, como resposta à nossa primeira questão de pesquisa.

Na etapa da análise formal-discursiva, busca-se a delimitação do corpus em termos de gênero discursivo, para o que se convocam, neste momento específico, mormente as orientações metodológicas de Gungher Kress (1989), que indica a análise dos lugares de fala dos participantes do evento social, dos elementos componentes da organização textual e dos 
propósitos ou finalidades reconhecidos em que se estabelecem os eventos sociais. Neste ponto, como já elucidamos, o Princípio de Integração dos Modos Semióticos encontra-se onipresente. Da mesma forma, procede-se a um constante exercício de interpretação e reinterpretação dos elementos multimodais constituintes dos textos analisados.

Assim, consecutivamente, identificam-se, descrevem-se e analisam-se as estratégias discursivas e os recursos semióticos derivados daquela análise de gênero, com o fito de tentar entender a democracia como elemento de coerção da ordem do discurso institucional. Fazemse presentes, nesta análise, as categorias da ADC, da TSSM e da HP, cada uma evocada no momento em que o corpus clama por determinado esteio doutrinário. Considerando que este se conforma primordialmente de textos multimodais, a aplicação do Princípio de Integração dos Modos Semióticos leva à integração de procedimentos analíticos, ao mesmo tempo em que os justifica.

A nossa análise, portanto, não é estanque, monocórdica ou unidirecional. Em sua proposta metodológica, Fairclough (2003, p. 6) defende uma relação dialética do estudo linguístico e multimodal, em que o foco "oscila" entre textos específicos e a ordem do discurso, a "estruturação social de uma língua/linguagem e sua parceria com determinadas práticas sociais".

O quadro da página seguinte busca clarificar a distribuição de métodos e categorias de análise no estudo. 
Quadro 5 - Organização Metodológica da Pesquisa Qualitativa

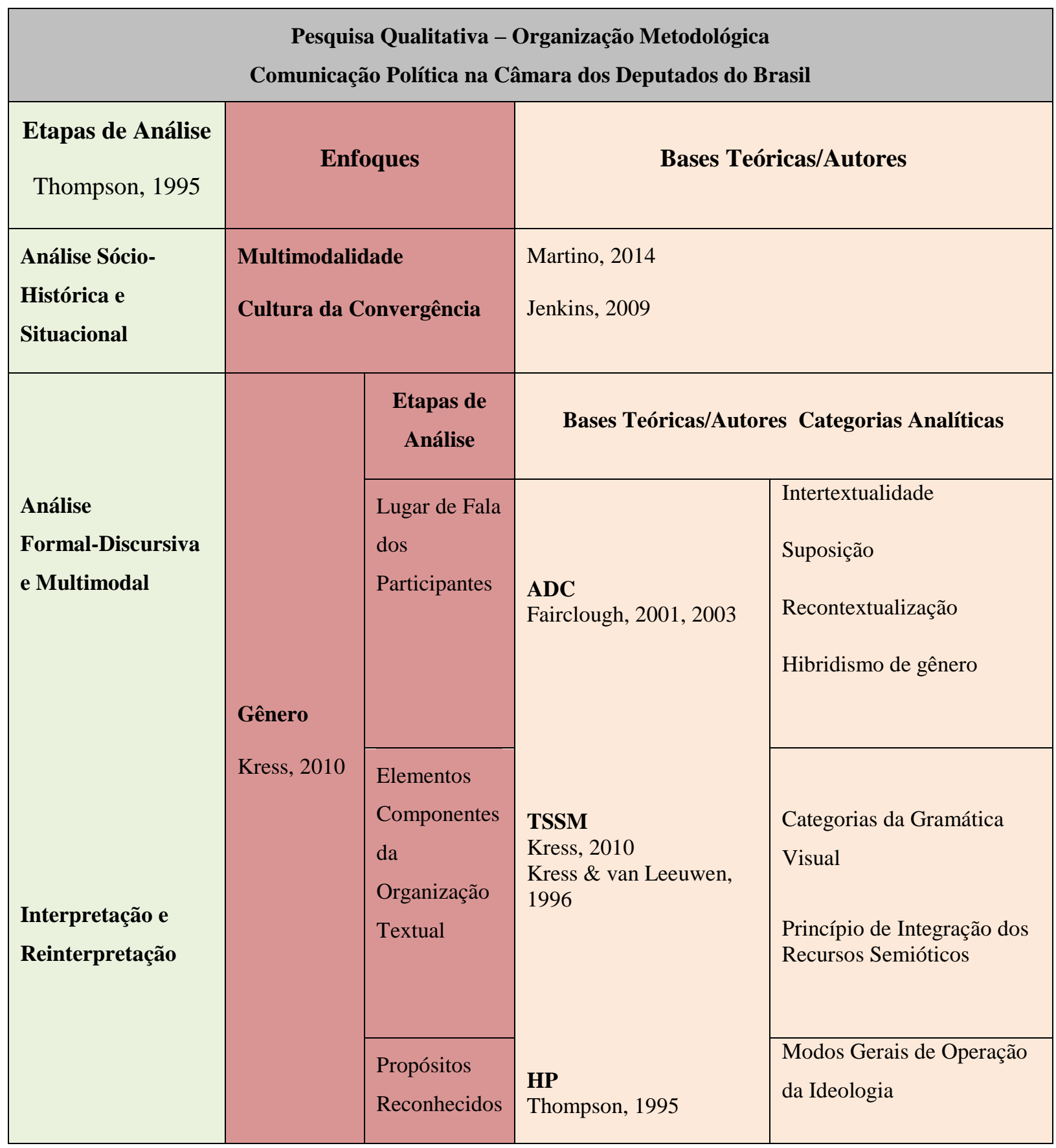

Fonte: Elaborado pela autora para este trabalho.

Feita a proposta de integração metodológica, invita-se à análise discursiva e multimodal do corpus. 


\section{CAPÍTULO 4}

\section{ANÁLISE DISCURSIVA CRÍTICA E MULTIMODAL}

\subsection{O CORPUS SOB A PERSPECTIVA DO GÊNERO DO DISCURSO}

O primeiro ponto a se ressaltar no estudo do gênero de uma produção discursiva dos órgãos de mídia da Casa de Leis é a complexidade da tarefa de delineamento daquela produção a um gênero estrito. Esse enredamento se deve à própria complexidade da ordem do discurso institucional e das práticas discursivas instanciadas naquela Casa do Poder Legislativo, por intermédio de seus órgãos, incluindo sua Secretaria de Comunicação, ou dos membros do Parlamento. Nesse sentido, argui Paiva (2015, p. 77):

[...] a complexidade da distribuição das práticas discursivas no seio de uma organização vai ser o combustível de sua própria (re)estruturação tanto do ponto de vista interno (mediante o estabelecimento, ou não, de práticas alternativas) quanto externo (em relação a outras instituições e respectivas ordens do discurso).

Com suas elucubrações, a autora nos leva a compreender que a prática discursiva, envolta em dissensões políticas e ideológicas, sofrerá as coerções das ordens da discurso e, em consonância com alterações nas práticas sociais, na organização e na estrutura social, poderá ser levada a redefinir fronteiras discursivas.

De toda sorte, a definição de discurso político, por si só, é questão controversa. Por isso, deve ser colocada em perspectiva, e, mais do que isso, deve-se optar por determinada perspectiva de análise.

Charaudeaux (2006, p. 28) discorre sobre a complexidade do campo político e nos auxilia a encontrar esse ponto de vista. Ao asseverar que "toda sociedade tem necessidade de reconhecer e de classificar as trocas realizadas", divide os campos de ação social em quatro domínios principais, conforme os desafios particulares de cada um: o jurídico, o econômico, o 
midiático e o político. O midiático tem como desafio "regulamentar a circulação da informação, de modo que esta atinja o maior número de cidadãos e, ao dizer-lhes respeito, permita-lhes ter uma opinião". Por sua vez, o desafio do setor político - aqui tomado em sentido estrito, segundo aquele autor - consiste em "estabelecer regras para a governança, distribuindo tarefas e responsabilidades mediante a instauração de instâncias legislativas e executivas".

É nesse sentido que até então vimos tratando do discurso político, como estrutura global, organizada e definida por certas relações de forças internas. Instanciadas nos órgãos dos Poderes Legislativo, consideramos que se tornam político-partidárias, ou seja, tomadas em seu sentido mais estrito. Neste último sentido, adotamos o termo discurso parlamentar.

$\mathrm{Na}$ análise que faz do discurso parlamentar, especificamente de discursos orais proferidos das tribunas do Plenário da Câmara dos Deputados, Paiva (2015) aplica a abordagem sociorretórica de Bazerman para o enquadramento, em gênero, das atividades sociais e discursivas havidas na instituição. Eis a definição de Bazerman (2005, p. 29) para gêneros:

Fatos sociais sobre os tipos de atos de fala que as pessoas podem realizar nos processos sociais em que pessoas tentam compreender umas às outras suficientemente bem para coordenar atividades e compartilhar significados com vistas a seus propósitos práticos.

Para aquele estudioso americano, as ações dos indivíduos seriam organizadas de modo estruturado e mediadas pelos gêneros em diferentes graus, conformando um sistema de atividades. Este sistema de atividades englobaria um sistema de gêneros responsável por reunir conjuntos de gêneros empregados pelos indivíduos no âmbito de uma mesma organização e os processos padronizados de construção (foco na regularidade). Por fim, o conjunto de gêneros seria formado por textos requeridos pelo desempenho de determinado papel social pelo indivíduo, conformados pela natureza do trabalho desempenhado. Assim estaria organizado e situado o sistema de gêneros:

sistema de atividades $>$ sistema de gêneros > conjunto de gêneros > gêneros/textos 
Aproxima-se dessa taxonomia (do mais abrangente ao menos abrangente) de Bazerman o método proposto pela Teoria Social do Discurso (FAIRCLOUGH, 2006, p. 89) para a análise de gênero, método que consiste de três passos: análise da cadeia de gêneros > análise da mistura de gêneros em um texto particular > análise do gênero individual em um texto particular.

cadeia de gêneros > mistura de gêneros em texto particular > gênero individual

Um primeiro ponto nos chama a atenção, na teoria de Bazerman. Ao tratar o gênero como tipos de atos de fala - ou seja, os fatos sociais ligados a estes tipos de atos - ou ao tratar o gênero como textos requeridos para o desempenho de determinado papel social por um indivíduo, Bazerman vai condensando e comprimindo sua noção de gênero a tal ponto, que não se consegue aplicá-la à voz de uma instituição política, ou seja, à voz do Parlamento, a menos que se a equipare à voz do "indivíduo". Insistimos, ainda assim, na análise feita por Paiva, neste movimento inicial de encontrar o "fio da meada“.

Paiva (Ibid., p. 38 e 79) aplica a teoria de Bazerman e constrói um esquema em que as atividades da Câmara do Deputados se subdividem em dois grandes sistemas: o sistema político e o sistema administrativo. Estes dois sistemas conformariam os dois grandes sistemas de gênero da Casa, cada qual abrigando um conjunto de gêneros menores. No sistema de gêneros políticos, estariam dois conjuntos: Plenário e Comissões. No sistema de gêneros administrativos, outros dois conjuntos: Administração da Casa e Mesa Diretora. Nota-se que, neste ponto, o que definiu os conjuntos foi a agência, personificada por estes principais órgãos da Casa de Leis, no âmbito do Parlamento.

Cada um desses conjuntos comportam gêneros diversos, tais como parecer, discurso, projeto de lei (Plenário); ata, pauta, convocação de Ministro de Estado (Comissões); processo de licitação, conta de telefone, realização de concurso público (Administração); registro de candidatura, declaração de perda de mandato, autorização de convênios (Mesa Diretora).

A exposição cultural, objeto de nossa análise, não parece enquadrar-se no sistema administrativo, tampouco no sistema político stricto sensu — ou seja, conforme o esquema construído por Paiva, os órgãos políticos da Casa — , pois neste caso se consideram atividades 
políticas da Casa aquelas empreendidas pelo Plenário e pelas Comissões. O nosso corpus de análise se constitui como produto da Secretaria de Comunicação Social da Casa, que se subordina diretamente à Presidência da Casa. Esta Presidência, como parte integrante da Mesa Diretora, estaria englobada no sistema administrativo. Contudo, reiteramos, uma exposição cultural certamente não se enquadra nas atividades administrativas da Câmara dos Deputados.

Assim, embora a elaboração teórica de Bazerman tenha sido profícua para o objeto de estudo de Paiva, discursos parlamentares orais ou escritos, não nos parece útil ao nosso esforço de enquadramento, ao gênero, de um texto da mídia parlamentar. Uma alternativa seria emparelhar aos sistemas de gêneros propostos um terceiro sistema, o de comunicação. Assim, haveria três sistemas no Parlamento: o sistema político de gêneros, o sistema administrativo de gêneros, o sistema comunicacional de gêneros. Mas, para tanto, teríamos que escoimar dos produtos de mídia, especialmente da mídia parlamentar, sua essência eminentemente política.

Levando-se em conta a natureza político-ideológica, nesse aspecto certamente não se poderiam emparelhar, sob o mesmo abrigo, um discurso proferido em plenário por um Deputado e uma ata de sessão, pois, embora empregados por indivíduos de uma mesma organização (o Plenário) e embora cada um dos apontados gêneros (ata e discurso oral) tenha processos padronizados de construção, faltar-lhes-ia a comunhão de tema/conteúdo e propósito (a ata não é eminentemente política, mas o discurso parlamentar certamente é), pelo menos não na perspectiva de gênero que elegemos, a da Teoria Semiótica Social de Kress (2010). Entretanto, cada um pode, de fato, conformar um gênero, o gênero ata e o gênero discurso parlamentar, conforme a seleção criterial de Paiva (baseada em Bazerman), ambos relacionados à produção ou às atividade dos órgãos políticos da Casa.

Toda essa discussão leva em consideração a delimitação que se aplica à esfera política. Caso se entenda, como Fairclough (2001, p. 94), que a esfera política engloba inclusive a ideológica (esta se originaria daquela, ou ali se constituiria), então qualquer texto seria, $a$ priori, político.

O discurso como prática política estabelece, mantém e transforma as relações de poder e as entidades coletivas [...] O discurso como prática ideológica constitui, naturaliza, mantém e transforma os significados do mundo de posições diversas nas relações de poder. Como implicam essas palavras, a prática política e a ideologia não são independentes uma da outra, pois a ideologia são os significados gerados em relações de poder como 
dimensão do exercício do poder e da luta pelo poder. Assim, a prática política é a categoria superior.

A Secretaria de Comunicação Social, a par de textos administrativos — todos os demais órgãos da Casa os produzem —, produz textos de comunicação social, ou seja, empreende prática discursiva estritamente relacionada à sua atividade fim. Assim, textos de imprensa ou midiáticos seriam os principais produtos elaborados por aquele órgão, conforme denunciam as suas competências, divulgadas na página virtual da Câmara:

a) divulgar as atividades da Câmara dos Deputados, com prioridade para aquelas diretamente relacionadas ao processo legislativo, por meio da distribuição de conteúdos informativos em suas emissoras de TV e rádio, jornal impresso e no portal de internet;

b) gerenciar o trabalho de assessoria de imprensa;

c) promover ações de relações públicas e divulgação institucional que aproximem o Poder Legislativo da sociedade, sejam presenciais ou com o auxílio de ferramentas de interatividade;

d) apoiar iniciativas que promovam o conhecimento e a cidadania;

e) gerenciar os veículos de comunicação interna. ${ }^{17}$

Decerto, "divulgar as atividades" e "distribuir conteúdos informativos" seriam atividades muito mais afeitas àquilo que Habermas (1984) chamaria de ações comunicativas, embora possam ser utilizadas — certamente assim se as utiliza — de forma estratégica. Fairclough (2003, p. 98) defende que "a distinção entre estratégica e comunicativa não é tão clara quanto parece" e, às vezes, ambas ocorrem em combinação.

De outro lado, "gerenciar veículos de comunicação interna" e "gerenciar o trabalho de assessoria de imprensa" seriam ações administrativas. Porém, a Secom não se furta a ações estratégicas, em que se enquadram perfeitamente estas: "promover ações de divulgação institucional" e "ações de relações públicas e divulgação institucional que aproximem o Poder Legislativo da sociedade".

A exposição cultural histórica Parlamento e Democracia foi montada com o objetivo de tratar cronologicamente dos grandes momentos do Parlamento brasileiro e mostrar sua importância para o regime democrático. Ademais, visava dar boas-vindas aos Deputados recém-empossados, mas também se dirigia às pessoas que visitam o Parlamento e às que o frequentam diariamente. Considerando seu diversificado público-alvo, pode-se dizer que se

\footnotetext{
${ }^{17}$ Disponível em: < http://www2.camara.leg.br/a-camara/estruturaadm/secom>. Acesso em: 16 out. 2015.
} 
trata de ações voltadas tanto às relações públicas (internas e externas) quanto à divulgação institucional.

Quanto ao enquadramento ao gênero, contudo, mesmo sendo possível delimitar um sistema de genêro, ou seja, o sistema de comunicação social, a demarcação do conjunto de gêneros torna-se mais complexa. Caso se tome como conjunto de gêneros, como fez Paiva, os agentes produtores ou os ambientes de produção (Plenário, Comissões, Mesa, Administração), poder-se-iam considerar os dois Departamentos da Secom, o de Mídias Integradas e o de Relações Públicas e Divulgação, assim como o Centro Cutural e as duas Coordenações (Apoio Técnico-Administrativo e Participação Popular). Dessa forma, cada um desses órgãos produziria seus textos particulares e característicos, que conformariam, cada um, um gênero.

Contudo, tal conformação não possibilitaria que se abrigasse num mesmo conjunto de gêneros, por exemplo, um programa televisivo de entrevistas, divulgado pela TV Câmara, pois esta atividade envolveria tanto o Departamento de Mídias Integradas quanto o de Relações Públicas e Divulgação, entre outros órgãos. A este último Departamento, verbi gratia, compete executar e supervisionar as atividades de comunicação interna e avaliar e propor exposições históricas, institucionais ou que envolvam artes plásticas, cênicas, cinematrográficas, etc., entre outras atribuições. Mas a execução da exposição Parlamento e Democracia ficou a cargo do Centro Cultural Câmara dos Deputados, e provavelmente contou com a participação (se não iniciativa) da Presidência da Casa, a quem o Secom se reporta - o que equivale dizer que houve, de alguma forma, interferência ou até ingerência do grupo hegemônico que ocupa a Presidência, incluindo o próprio Presidente.

De outra forma, colocando-os todos sob a égide da Secom, ou seja, o conjunto de gêneros que se derivariam das atividades da Secretaria de Comunicação, ter-se-ia o ombreamento de gêneros tão díspares quanto uma sessão de homenagem a um Chefe de Estado estrangeiro, um relatório de atividade sobre a participação popular na Casa, o atendimento à sociedade por via do "0-800", os chats realizados pela página e-Democracia ou notícias do Jornal da Câmara. Não obstante o ensinamento bakhtiniano de que os gêneros são tão diversos quanto as atividades humanas, o estudo do gênero consiste justamente em encontrar para o texto uma delimitação, uma demarcação, uma organização, um enquadramento em uma formação discursiva.

Enfim, ao chamar atenção para a complexidade da análise, prosseguimos a 
investigação, tomando como supedâneo o método de Kress para o estudo do gênero. Kress (1989, p. 19) propõe que se proceda às análises — não necessariamente de forma consecutiva - dos lugares de fala dos participantes discursivos, dos elementos componentes da organização textual e dos propósitos reconhecidos ou finalidades em que se estabelecem os eventos sociais.

Antes de prosseguirmos na análise do gênero por meio das categorias propostas por Kress (lugares de fala, organização textual e propósitos), fazemos algumas considerações a respeito de aspectos preliminares que emergem da intertextualidade, nesta análise transdiciplinar.

\subsubsection{Considerações sobre a intertextualidade no corpus}

Diante da possibilidade — esta que se nos avista — da ocorrência de "texto misto" em termos de gênero, Fairclough (2003, p. 68) indica a intertextualidade como critério delimitador do gênero discursivo ( $v . g$. o gênero jornalístico, em que a intertextualidade manifesta favorece a "distribuição entre as vozes autorais e as vozes atribuídas"). Como se pôde observar na exposição Parlamento e Democracia, muitos são os relatos diretos, as citações diretas das falas, mas há textos e imagens de autoria da instituição Câmara dos Deputados, por meio de sua Secretaria de Comunicação Social. E, de resto, toda a composição é de autoria deste órgão.

Nesta busca pelo enquadramento de gênero, imperiosa se faz a verificação e o emiuçamento desse caráter interdiscursivo do texto, ou seja, uma mistura particular de gêneros, discursos e estilos realizados na semântica, na gramática, no léxico.

Assim, busca-se neste ponto, inicialmente, responder à pergunta proposta por Fairclough (2003, p. 64) para a análise da intertextualidade: quais textos e vozes são incluídos? Que ausências significantes há? E, acrescentamos, por que foram incluídas ou excluídas esses textos e essas vozes?

Vale notar que todos os textos internos do folder constituem-se de incorporações de outras vozes, algumas mais recentes, outras bem antigas. Mas todas guardam em comum o 
pensamento registrado de personalidades com alguma relevância histórica, e suas manifestações trasladadas apresentam coincidência temática: a democracia, o Parlamento, e os perigos que os rondam.

Todas se expressam em relato direto (Fairclough, 2003, p. 67), ou seja, há a citação das palavras realmente usadas pelos oradores, nominalmente citados. $\mathrm{O}$ verbo dicendi se faz representar pelos balões desenhados, que unem os oradores às suas falas, como já mencionado. A dialogicidade ampla caracteriza o texto, pela forte marcação da diferença (o implícito dificulta a dialogicidade e a crítica).

Conforme já se mencionou acima, um dos inimigos da democracia - neste caso, a oposição é óbvia - são os regimes ditatoriais e seus defensores. Contudo, o outro adversário, em relação ao qual o cidadão precisa manter-se alerta, segundo a exposição e o folder, é aquele que se personifica no Poder Executivo. Às vezes citado textualmente, outras vezes tratado como "governo", nunca porém se revela escancarado como alvo de crítica e oposição.

Mas, se algum inimigo oculta-se em estratégias discursivas de dissimulação ou deslocamento, na totalidade das manifestações os autores encontram-se devidamente nominados e contextualizados historicamente (data de nascimento e morte), teleologicamente irmanados e jungidos na defesa do regime democrático e, por extensão, do próprio Parlamento. Recorre-se à autoridade histórica destas personalidades para, em suas palavras, ver fortalecida a legitimidade e a condição de imprescindibilidade ou indispensabilidade do Poder Legislativo.

Trata-se da busca pela legitimação de um poder sob questionamento, sob a mira de grandiosas e não totalmente compreendidas manifestações populares, que se materializaram e ainda se materializam nas ruas e nas redes. Do que se vem depreendendo desta análise linguístico-semiótica, a exposição Parlamento e Democracia manifesta e concretiza - de forma bastante impactante, forte, enérgica — os esforços envidados pela Casa do Povo para manter uma identidade com o cidadão comum que a conforma, ao mesmo tempo em que se quer demonstrar altaneira e orgulhosa por ser agregadora de homens de elevada honra e estirpe.

Poder-se-ia dizer que se trata de contradição ou ambivalência. Contudo, neste movimento pendular de busca por identificação e simultânea afirmação de autoridade — notese a presença absoluta dos argumentos de autoridade — , de aproximação e de afastamento, 
constrói-se a coerência na prática discursiva: a de uma instituição que guarda em sua própria essência, que é a democracia, a sua maior limitação discursiva. Aquilo que a compõe é, a um só tempo, aquilo que a constrange.

Ao teorizarem o processo político e as noções de hegemonia, Laclau e Mouffer (1985 apud Fairclough, 2003, p. 144) indicam esse trabalho simultâneo de duas lógicas diferentes: a lógica da diferença, que cria distinções e divisões; e a lógica da equivalência, que subverte a existência de segmentações.

Em verdade, ainda neste ponto se apresenta bastante complexo e heterogêneo o objeto de estudo, a começar pelo enquadramento genérico da exposição histórica e dos textos que a compõem. Mas para Fairclough (2001, p. 137) o exame da intertextualidade implica justamente a ênfase nessa heterogeneidade, que demanda um modo de análise "que ressalta os elementos e as linhas diversos e frequentemente contraditórios que contribuem para compor um texto".

Daí porque não se pode estreitar ou adstringir o exame crítico. Este descreve, explica, interpreta e reinterpreta. Nesse sentido, em comentário às "formações discursivas" de Pêcheux, Fairclough (2001, p. 56) aduz:

Dada a heterogeneidade constitutiva do discurso, partes específicas de um texto serão frequentemente ambivalentes, pondo questões para os intérpretes sobre as FDs [formações discursivas] mais relevantes para a sua interpretação e, como observa Pêcheux em um de seus últimos trabalhos (1988), conferindo à análise de discurso o caráter de uma disciplina interpretativa e não diretamente descritiva.

Coaduna-se tal pensamento com a hermenêutica de profundidade proposta por Thompson (1995), que propõe como último passo metodológico a interpretação e reinterpretação das formas simbólicas. Este é outro viés do exame, a identificação e interpretação dos modos de operação da ideologia, sem perder de vista a persecução maior do estudo: a definição do gênero do discurso.

Mas o foco ajusta-se também sobre os recursos semióticos do modo visual, a fim de se integralizar e consolidar a análise multimodal, o que se dá por meio da aplicação do princípio 
que, por ser o coração da análise, encontra-se nela de modo onipresente: a aplicação do princípio de integração dos recursos semióticos (dos modos escrito e imagético, no caso). Por meio desse procedimento, intenta-se maior aproximação ao sentido global do texto sob exame.

Considerando a heterogeneidade constitutiva do discurso, e por não pretender este estudo adstringir-se a um apenas arcabouço teórico-metodológico, prosseguimos este exame de corpus desta maneira, integrada, jungindo as orientações doutrinárias que, afinal, tangenciam-se, em alguma zona da interdiscursividade. O fio condutor desta análise, portanto, é a intertextualidade. E, concomitante e complementarmente, analisam-se os modos de operação da ideologia, por meio da identificação de estratégias típicas de construção simbólica (THOMPSON, 1995). Enfim, vai-se exaurindo aos poucos a análise linguística multimodal proposta, por meio do desvendar dos significados construídos pelos recursos semióticos visuais selecionados pelo sign-maker para a composição do folder. Não se implementa a análise, portanto, de forma estanque, por se entender que a heterogeneidade dos textos clama e justifica a heterogeneidade do método.

Escoimando daqui e dali as partes menos eloquentes para o desvendar do sentido ideológico do texto (conforme a "seleção criterial" desta pesquisadora), atenta-se aos modos semióticos vários que compõem os textos nos modos escrito e visual.

Relembrada a integração dos procedimentos de trabalho, retomamos a análise propriamente dita.

\subsubsection{Dos lugares de fala dos participantes discursivos}

Buscamos luz em Patrick Charaudeau (2006), indagando-nos, antes de tudo, quem são os participantes do evento discursivo ou ato comunicativo em apreço. Para Kress (1989, p. 37), discursos e gêneros controem "posições do sujeito", estabelecem papéis para os sujeitos ou lugares de fala para os participantes discursivos, posicionando-os em relações simétricas ou assimétricas, atribuindo-lhes direitos e deveres. 
Charaudeau argui (2006) que, no âmbito da comunicação política, há primordialmente duas instâncias implicadas: a instância política, que assume a ação política, por delegação; e a instância cidadã, fonte primária do poder, que delega este poder à primeira. De sua parte, a instância política ${ }^{18}$ guarda o lugar da governança e seus atores têm o poder de fazer (decidir e agir) e de fazer pensar (manipular). Por meio de seus discursos, propõe programas políticos, justifica decisões e ações para defender sua legitimidade, critica ideias oponentes, conclama o consenso social e o apoio cidadão, por meio de persuasão e sedução.

Por sua vez, a instância cidadã - noção atinente a regimes democráticos -, forma-se simbolicamente pelo agrupamento de indivíduos de uma mesma comunidade nacional que juntos querem estar (sociedade civil, afetiva) e viver (sociedade cidadã, racional), e posicionase em um lugar em que, também, "a opinião se constrói fora do governo". Produz discursos de reivindicação (protesta contra decisões, ações ou omissões governamentais), de interpelação (exige explicações ou ações) e de sanção (elege, reelege ou depõe os representantes do povo).

Exsurge, desta relação contratual abstrata, uma primeira tensão, dissensão ou contradição:

[...] ela [a instância política] chegou ao poder por uma vontade cidadã (e não autoritária), mas esta, não estando encarregada dos negócios do Estado, não conhece as regras de seu funcionamento e ignora as condições de realização da ação política. A instância política, que é de decisão, deve, portanto, agir em função do possível, sendo que a instância cidadã a elegeu para realizar o desejável. Nasce, assim, um exercício difícil do poder político, que consiste em ditar a lei e sancioná-la, sempre se assegurando do consentimento da instância cidadã. (CHARAUDEAU, 2006, p.18).

De certo modo, deriva deste entendimento a noção de "dominação legítima" em Weber (1964), que justificaria, segundo aquele filósofo, até a violência legal do Estado, cuja necessidade é contestada por Arendt (1972). Para Habermas (2003), a instância política encontra-se entre "dois processos contrários: a produção comunicativa de um poder legítimo [...] e a constituição dessa legitimação pelo sistema político, com o qual o poder administrativo estabelece uma relação reflexiva".

\footnotetext{
${ }^{18}$ Para o linguista francês, há uma instância adversária ou antagonista, que também se encontra no lugar de governança e, dali, constrói discurso análogo, ao exercer o papel de oposição aos representantes do Estado, dos governos, dos parlamentos e das instituições atinentes.
} 
Sobre esta condição definida pela Constituição Federal da República Federativa do Brasil, pronuncia-se o constitucionalista José Afonso da Silva (2000, p. 143, grifo do original), ao discorrer sobre o mandato político representativo:

O mandato representativo é criação do Estado liberal burguês, ainda como um dos meios de manter distintos Estado e sociedade, e mais uma forma de tornar abstrata a relação povo-governo. Segundo a teoria da representação política, que se concretiza no mandato, o representante não fica vinculado aos representados, por não se tratar de uma relação contratual; é geral, livre, irrevogável em princípio, e não comporta ratificação dos atos do mandatário.

A legitimidade da representação política btida por mandato (e não pela força) originase no poder popular, na tomada de poder pelo povo por meio de um sistema de delegação de poder. Contudo, justamente por se tratar poder delegado, este é também provisório, pois não provém nem de filiação biológica nem divina, mas da vontade humana. Por isso, pode ser - e de fato é - constantemente questionado e contestado.

Assim, as Casas do Poder Legislativo, em especial a Câmara dos Deputados, ao tempo em que produzem seus textos eivados da legitimidade que lhes concedeu a apuração das urnas — e as próprias regras do sistema político constitucional —, permanecem constantemente instadas a defender e a consolidar essa posição de dominação legítima, permanentemente ameaçada, assim como se encontra permanentemente ameaçado o próprio regime democrático, como testemunha a história do Brasil e do mundo. Uma crise de legitimidade e/ou de credibilidade (como a atual, no País) põe em risco o próprio regime democrático, que é essência e identidade do Parlamento.

Nesse contexto, o poder comunicativo torna-se elemento chave na esfera das lutas hegemônicas, no âmbito político. Não é por outra razão que Charaudeau (2006, p. 19) conclui que:

[...] o poder comunicativo remete à busca da dominação legítima - que, sem necessariamente justificar a violência, garante o acesso da instância política ao poder, ou sua manutenção nessa posição -, pois ela se encontra permanentemente ameaçada de sanção física (golpe de Estado), institucional (derrubada de poder) ou simbólica (descrédito). 
Destarte, no contrato da comunicação política há uma terceira instância, a par das instâncias política e cidadã: a instância midiática ${ }^{19}$ (CHARAUDEAU, 2006, p. 62), que se encontra fora da governança e busca unir as instâncias política e cidadã, por meio de dispositivos como exibição (busca por credibilidade) e espetáculo (busca por cooptação). No primeiro caso, incluem esforços voltados inclusive a capturar o que mascaram as declarações dos políticos. Assim resume Charaudeau (2006, p. 64, grifo nosso) as representações de cada instância:

O dispositivo do contrato de comunicação política é, de certa forma, uma máquina de forjar discursos de legitimaçãa que constroem imagens de lealdade (para a instância política), que reforçam a legitimidade da posição de poder; de protesto (para a instância cidadã), que justificam a legitimidade do ato de tomar a palavra; de denúncia (para a instância midiática), que mascaram a lógica comercial pela lógica democrática, legitimando esta em detrimento daquela.

No quadro da página seguinte, buscamos sintetizar os papéis de cada um desses sujeitos ou instâncias.

\footnotetext{
${ }^{19}$ Essas instâncias seriam entidades humanas tomadas como categorias abstratas, conforme o papel que exercem na interação e a intencionalidade que as impulsiona.
} 
Figura 23 - Instâncias da Comunicação Política, com base em Charaudeau (2006).

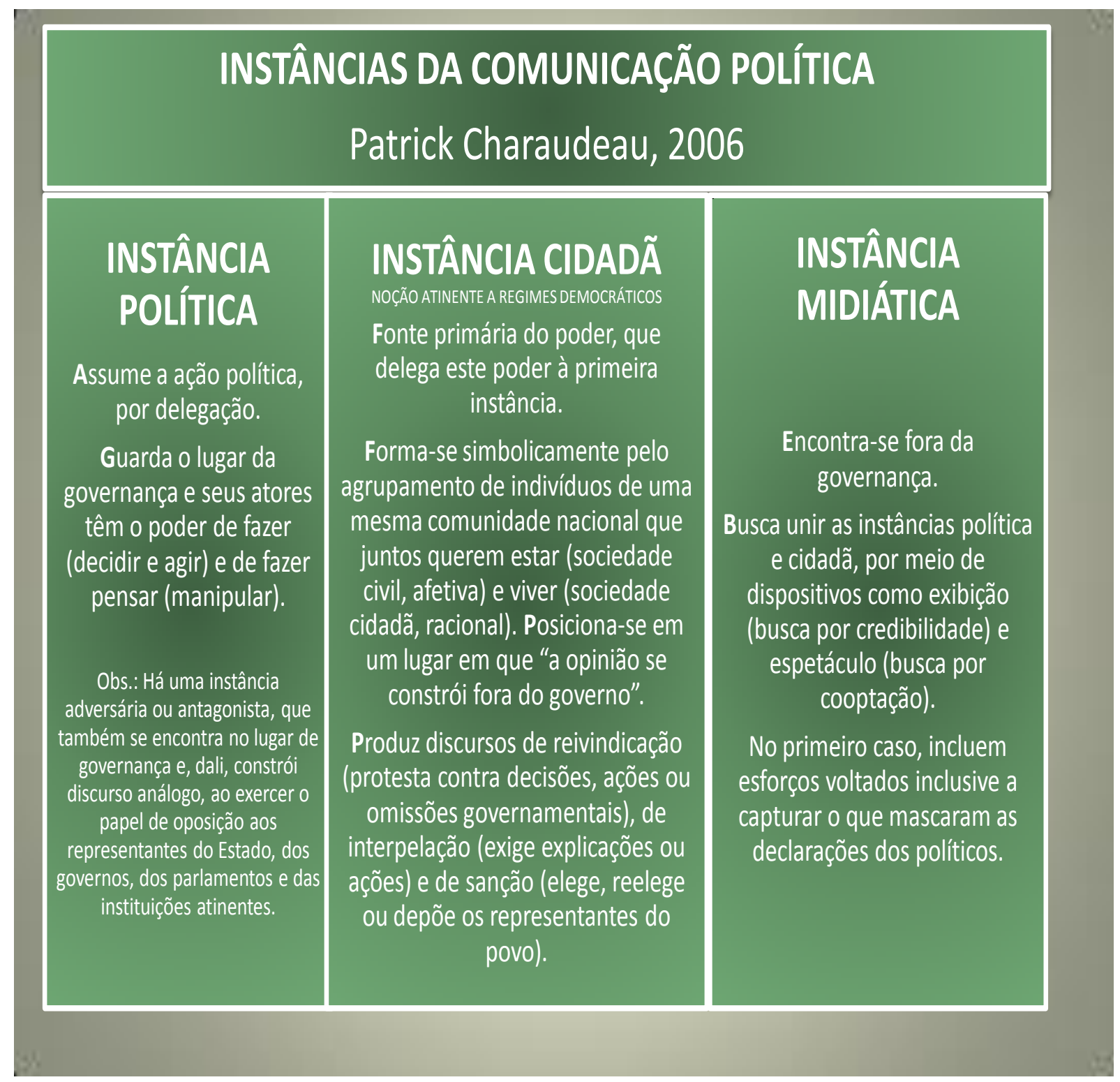

Fonte: Elaborado pela autora para este estudo, com base em Charadeau (2006).

O exame dos papéis dessas três instâncias nos permite elucubrar sobre o papel da mídia estatal, mormente dos órgãos de comunicação da Câmara dos Deputados do Brasil, que divulgam as atividades legislativas e institucionais, mas também produzem matérias de cunho cultural e social por meio da TV Câmara e da Rádio Câmara (cuja cobertura se vem expandindo por todo o País, de acordo com o projeto da Rede Legislativa), do Jornal da Câmara (impresso, mas reproduzido virtualmente) e da Agência Câmara (que engloba o jornal virtual Câmara Notícias e todo o site). 
Ao falarmos da mídia institucional, que se personifica em sua Secretaria de Comunicação Social, a que produziu os textos ora analisados, não estamos tratando da mídia de Charaudeau, aquela que se encontra "fora da governança" e atende à lógica do mercado: os órgãos de comunicação da Câmara do Deputados fazem parte da governança, produzem discursos de governança (FAIRCLOUGH, 2003) e, sobretudo, são a própria voz da governança.

Trata-se, enfim, de um tipo particular de mídia. Parecem jungir-se, na mídia institucional pública, elementos das três instâncias. A Câmara dos Deputados compõe-se de representantes da instância cidadã, de quem herda um poder delegado (mas a "vontade" da instância cidadã não vincula ou condiciona a ação parlamentar). Assim, a instituição promove o debate público, interpela e fiscaliza o Poder Executivo, mas sofre as sanções da própria instância cidadã, que pode depor ou não reeleger seus representantes. De outro modo, promove a difusão das leis criadas pela Casa, exercendo também o papel de governança sobre os cidadãos, por meio da elaboração de leis. Por fim, promove o debate acerca dos temas de interesse da sociedade e exerce o papel da mídia no que diz respeito à lógica democrática (participação e transparência), que a legitima, conforme anunciou Charadeau, sem se submeter à lógica de mercado.

Se tal isenção (à lógica de mercado) aparentemente torna a mídia institucional pública independente e, portanto, mais poderosa, não a livra de uma restrição que lhe impõe a ordem do discurso (FOUCAULT, 2006) no Parlamento - e que, a priori, parece ser muito mais pesada: seu discurso deve garantir, sobretudo, a sustentação da democracia, que lhe é salvaguarda da própria existência.

Ao se analisar sob outra perspectiva esse sujeito participante do evento comunicativo, pode-se afirmar que, se a mídia parlamentar é a voz do Parlamento, é preciso saber quem está à frente do Parlamento - e não somente quem o preside, mas qual é o grupo dominante e suas orientações ideológicas ou, em outras palavras, o ponto de vista particular do produtor do texto. A exposição foi produzida sob a presidência do Deputado Eduardo Cunha, cujo perfil se encontra publicado no site da Câmara dos Deputados:

Eduardo Cosentino da Cunha, ou simplesmente deputado federal Eduardo Cunha, atual presidente da Câmara Federal [...] foi um importante executivo da área de telecomunicações, sendo responsável pela implantação da 
telefonia celular no Brasil [...]. Sua maior conquista eleitoral aconteceu em 2010, quando, pelo PMDB, foi o quinto deputado federal mais votado do Estado do Rio de Janeiro, com 150.616 votos. [...] Foi líder do PMDB, entre fevereiro de 2013 e fevereiro de 2015, quando foi eleito presidente da Câmara. Nascido no Rio de Janeiro em 1958, Eduardo Cunha é radialista, evangélico, casado e pai de quatro filhos. Economista, formado na Universidade Cândido Mendes [...]. ${ }^{20}$

O Presidente da Casa, considerado político representante da direita conservadora, participa da Bancada Evangélica, da Bancada contra o Aborto e da Bancada do Direito à Legítima Defesa, entre outras. Portanto, posiciona-se contrário aos direitos de minorias como a dos homossexuais - vale dizer que o Deputado Eduardo Cunha é autor do Projeto de Lei

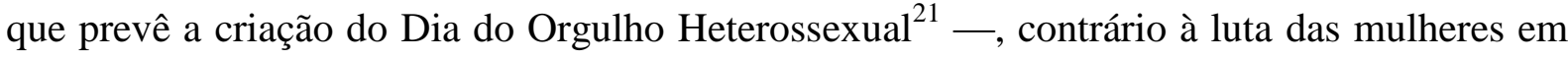
relação à emancipação de decidir sobre o seu próprio corpo, e favorável à comercialização regulamentada de armas de fogo.

O site Atlas Político, que busca mapear e ranquear o perfil dos parlamentares por meio de alguns critérios, apresenta o perfil do Deputado Eduardo Cunha, apresentado na figura da página seguinte.

\footnotetext{
${ }^{20}$ Fonte: Disponível em: <http://www2.camara.leg.br/a-camara/presidencia/biografia/>. Acesso em: 19 out. 2015.

${ }^{21}$ Fonte: Disponível em: <http://www.ebc.com.br/noticias/politica/2015/02/camara-desarquiva-projeto-deeduardo-cunha-que-cria-o-dia-do-orgulho.> Acesso em: 19 set. 2015.
} 
Figura 24 - Mapa Político do Deputado Eduardo Cunha, pelo site Atlas Político

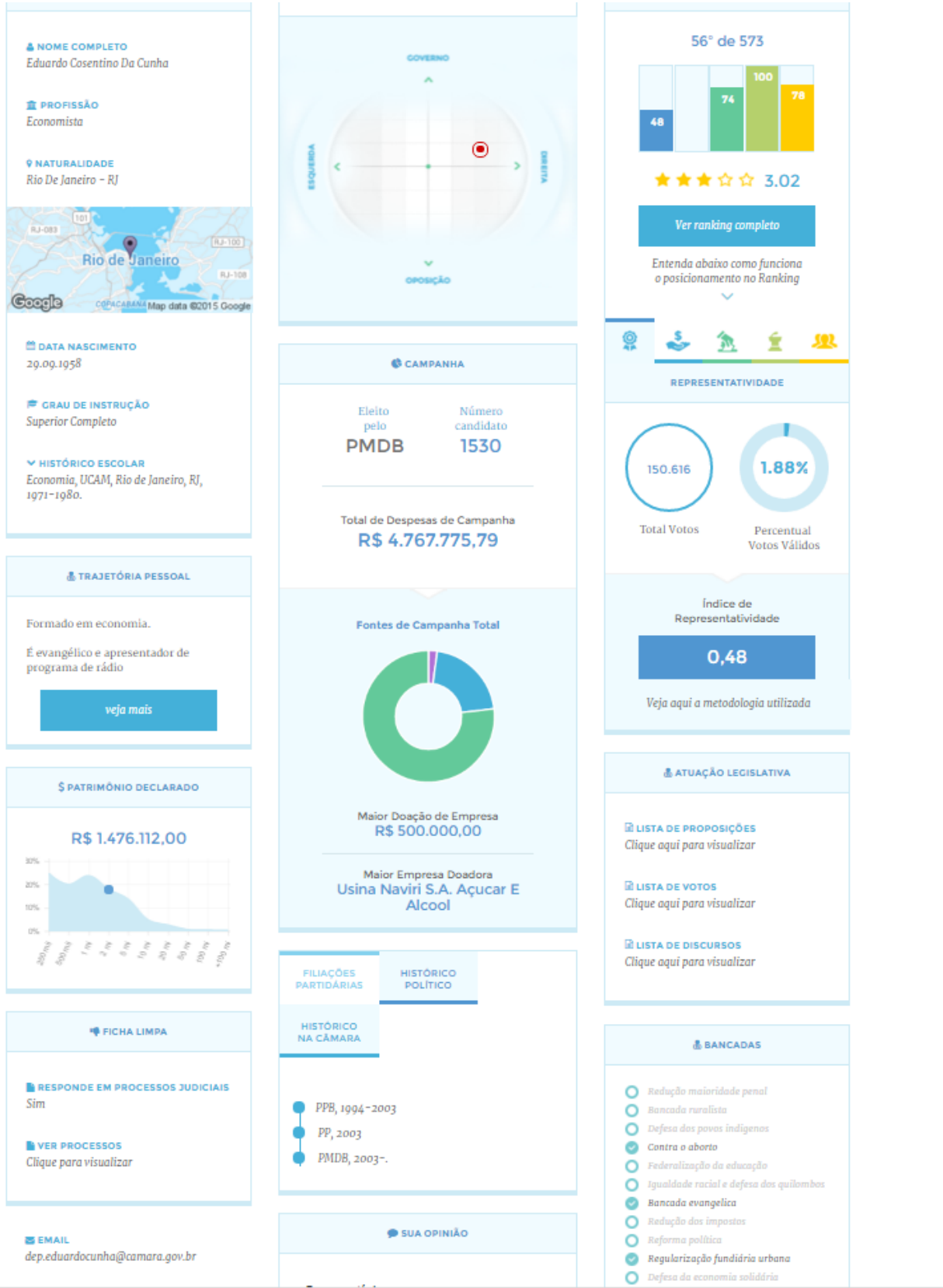

Fonte: <Disponível em: http://www2.camara.leg.br/a-camara/presidencia/biografia/>. Acesso em: 19 out. 2015.

O quadrante central superior indica, com um ponto vermelho, o posicionamento do político como de direita e governista. Foto exposta na mostra histórica sob exame representa e delata este posicionamento político-ideológico, ao retratar o lado direito do plenário, historicamente ocupado por partidos de direita e centro-direita. O corte ou descarte do lado esquerdo do plenário é visível, e revela um ponto de vista inequívoco do produtor do texto (KRESS; VAN LEEUVEN, 1996, p. 135). 
Figura 25 - Foto do Plenário da Câmara dos Deputados, em perspectiva.

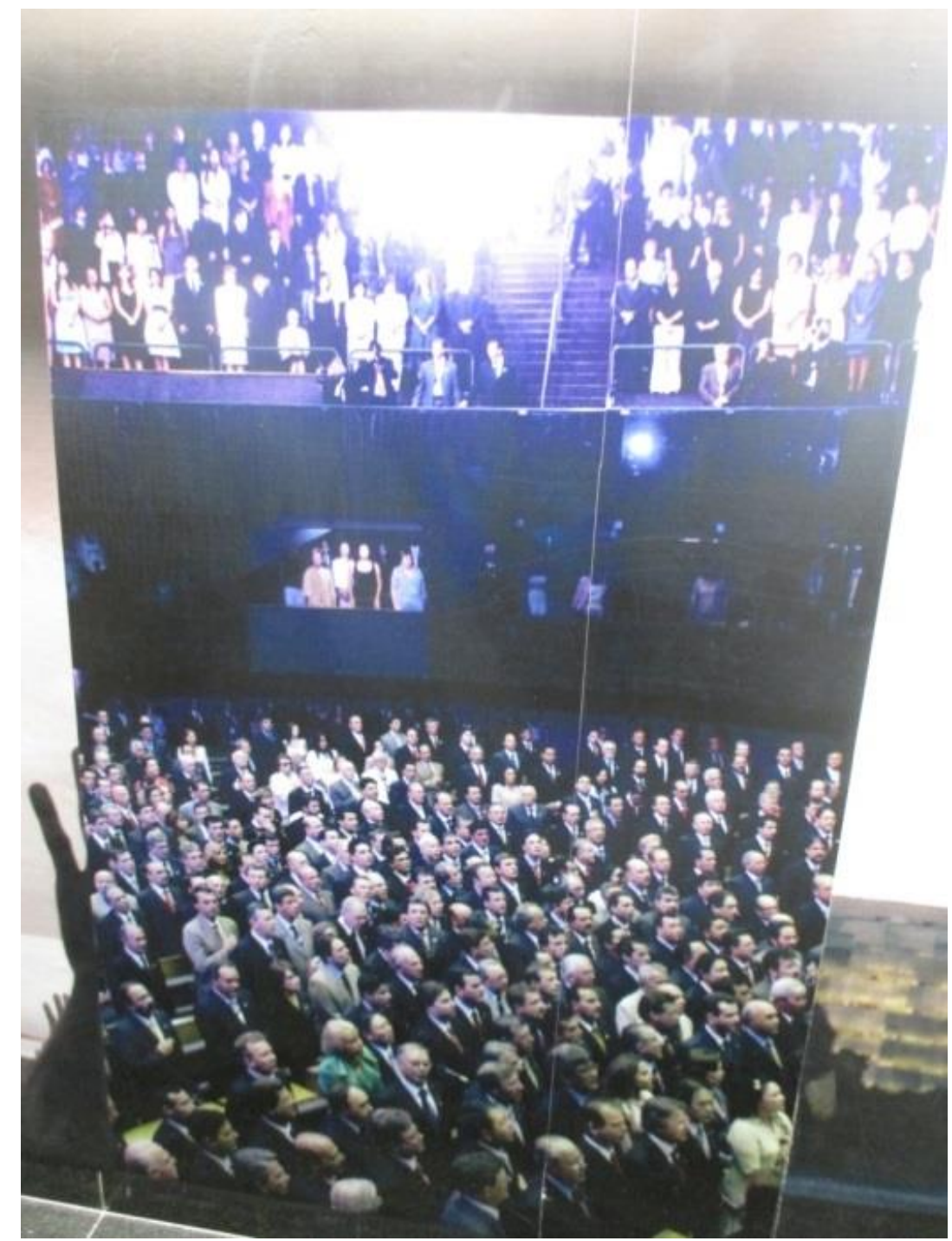

Fonte: Acervo pessoal da autora (foto da exposição Parlamento e Democracia)

Não se pode deixar de dizer que este posicionamento partidário "governista", apontado pelo Atlas Político, já vinha dando mostras de fragilidade. Em verdade, o próprio Presidente da Câmara rompeu com a Presidente da República, meses depois, de forma independente, inicialmente sem o apoio do partido. Contudo, a base de apoio ao Governo, na Câmara dos Deputados acabou por ruir completamente no segundo semestre de 2015.

Nos textos da exposição Parlamento e Democracia, figuras históricas do partido hegemônico, o PMDB, e de partidos coligados receberam destaque, como Ulysses Guimarães, Dante de Oliveira, João Cunha (não tão notório quanto os dois primeiros, mas, talvez coincidentemente, com o mesmo sobrenome do então Presidente da Casa, Eduardo Cunha). 
Citados foram Pedro Aleixo, um dos fundadores da União Democrática Nacional em 1945, partido de orientação conservadora; e também Tancredo Neves, que chegou a ser PrimeiroMinistro do Brasil, na breve experiência Parlamentarista. Foram desprezadas personalidades de esquerda, com raras exceções, como Leonel Brizola, do Partido Democrático Trabalhista. Quase todos os participantes representados, contudo, já estavam falecidos, à exceção de Collor de Mello (o ex-Presidente que sofreu processo de impeachment), então Senador da República, no início de 2015.

Note-se a representação de uma das personalidades históricas, Bernardo Pereira de Vasconcelos, cuja história política coaduna-se com a do grupo hegemônico que ora se estuda. Qualifica-se o participante representado na exposição como fundador do Partido Conservador e autor do Código Criminal do Império. Esta menção indireta à função repressiva do Estado é constante em toda a exposição.

Figura 26 - Foto de Bernardo Pereira de Vasconcelos

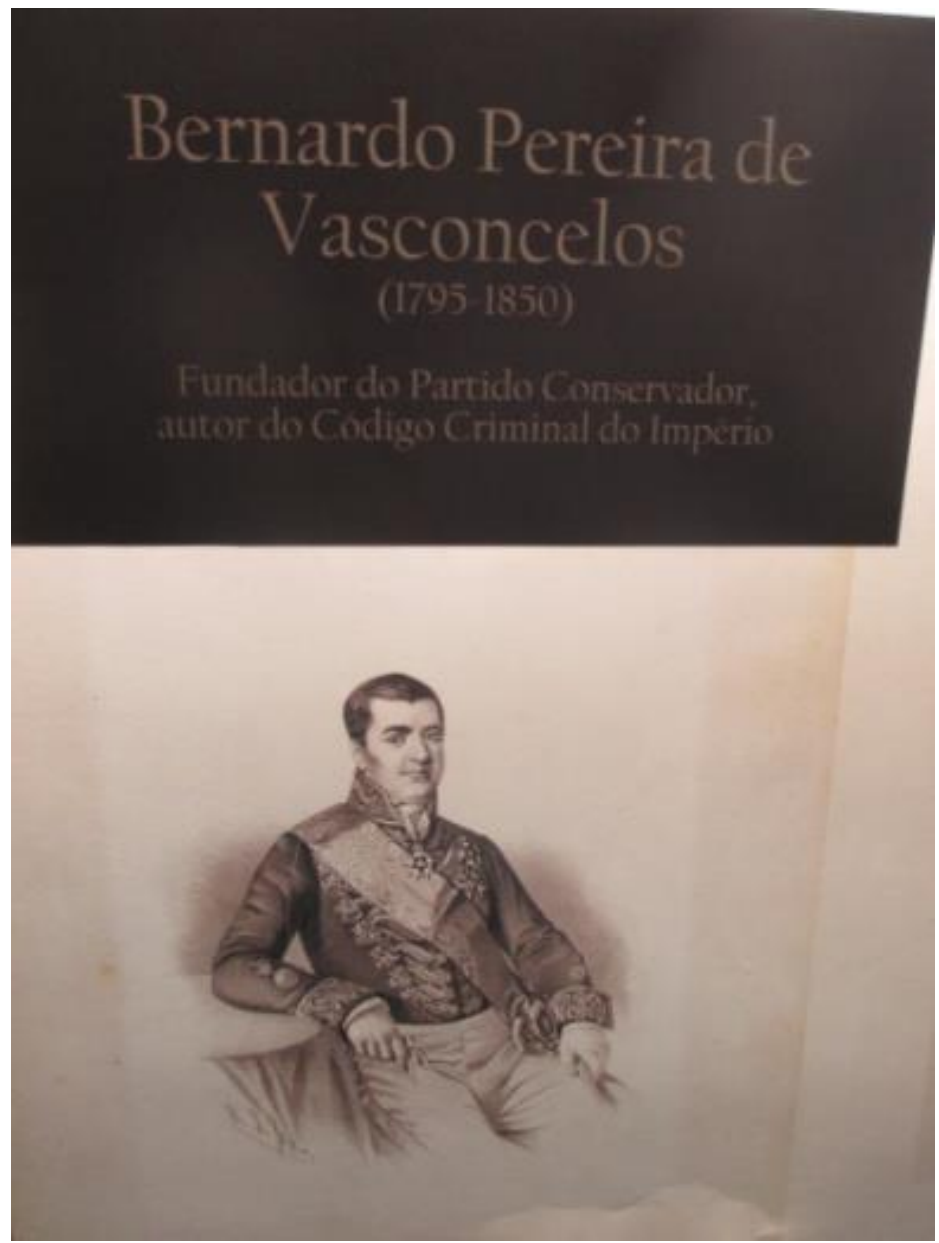

Fonte: Acervo pessoal da autora (foto da exposição Parlamento e Democracia). 
Mas as perspectivas do produtor do texto se emolduram, também, pelos temas eleitos na mostra. Fairclough (2006) ensina a reconhecer diferentes discursos em um texto, em dois passos: identificar as principais partes representadas do mundo (inclusive áreas da vida social), os "temas" principais; e identificar a perspectiva, o ângulo ou ponto de vista particular do qual são representados. Bakhtin (1992 [1929]), nesse sentido, trabalha com a noção de conteúdo temático, um dos componentes do enunciado, que incorpora o objeto discursivo e a finalidade discursiva. Temas seriam, para Baktin (Ibid.), conteúdos ideologicamente conformados.

Decerto, no discurso do Parlamento, a democracia constitui-se como tema principal ou, em termos de finalidade discursiva, a defesa da democracia — que é, em última instância, condição de existência do próprio Parlamento. Como subtemas — ou, como preferimos chamar aqui, tópicos - , podem ser elencados estes: liberdade, regime de governo, separação e independência dos Poderes, Constituição, etc. Minudenciam-se, ainda, subtópicos como impeachment, ditadura, intervenção militar, minorias, entre outros. Destes, constrói-se um discurso sob a perspectiva do grupo hegemônico na Câmara dos Deputados do Brasil, aquele que ocupa a Presidência da Casa e os principais cargos. Dessa forma, por meio do balizamento do perfil político-ideológico do partido e da coligação, bem assim o perfil do Presidente da Casa, permite-se o entendimento da perspectiva que adotam, no texto estudado, os agentes produtores e distribuidores do evento discursivo.

Nas páginas seguintes, buscamos algumas perspectivas político-ideológicas do grupo hegemônico da Câmara dos Deputados do Brasil, na 55ª Legislatura, com base no corpus de análise. À esquerda, alguns temas e tópicos evocados na exposição, com fotos extraídas da exposição, as quais ilustram os temas; à direita, as perspectivas particulares dos agentes produtores do evento discursivo. 
TEMAS, TÓPICOS E SUBTÓPICOS, ABORDADOS NO CORPUS. (REPRESENTAÇÃO DO MUNDO)

\section{PERSPECTIVA PARTICULAR DO GRUPO HEGEMÔNICO DA CÂMARA DOS DEPUTADOS DO BRASIL}

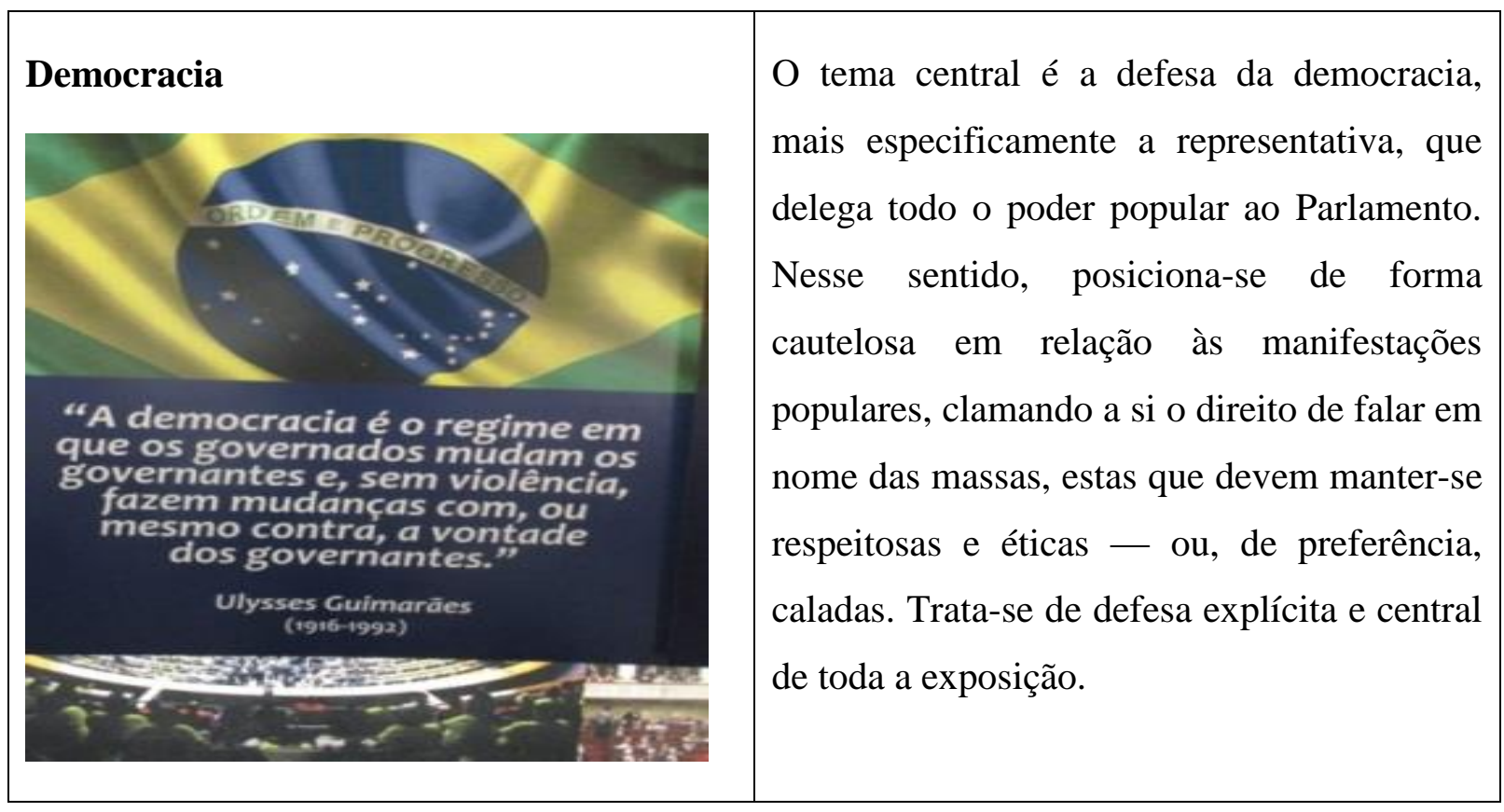

Regimes de Governo, Presidencialismo e Parlamentarismo

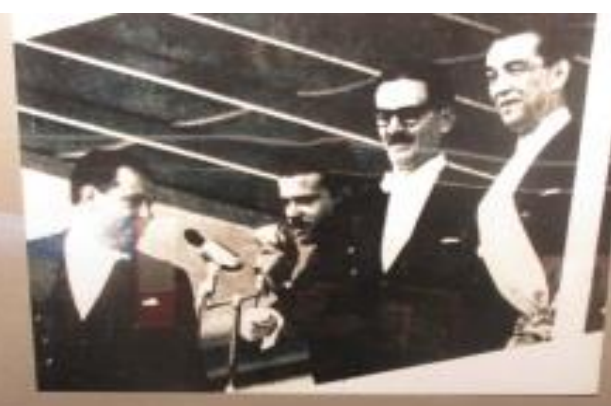

A BREVE EXPERIÊNCIA PARLAMENTARISTA A

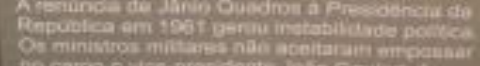

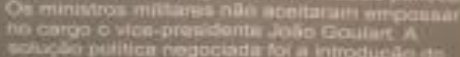

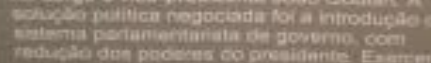

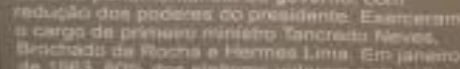

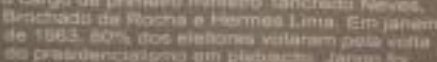

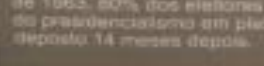

Patente, no corpus, a defesa do regime parlamentar, que, por óbvio, significa o empoderamento do Poder Legislativo, em detrimento da autoridade do Executivo. Não se trata de defesa explícita, mas inferida da análise crítica textual. Defende-se a consolidação, a partir das revoluções liberais burguesas do século XVIII (em especial, a francesa) do modelo parlamentar como instituição ao regime democrático. 


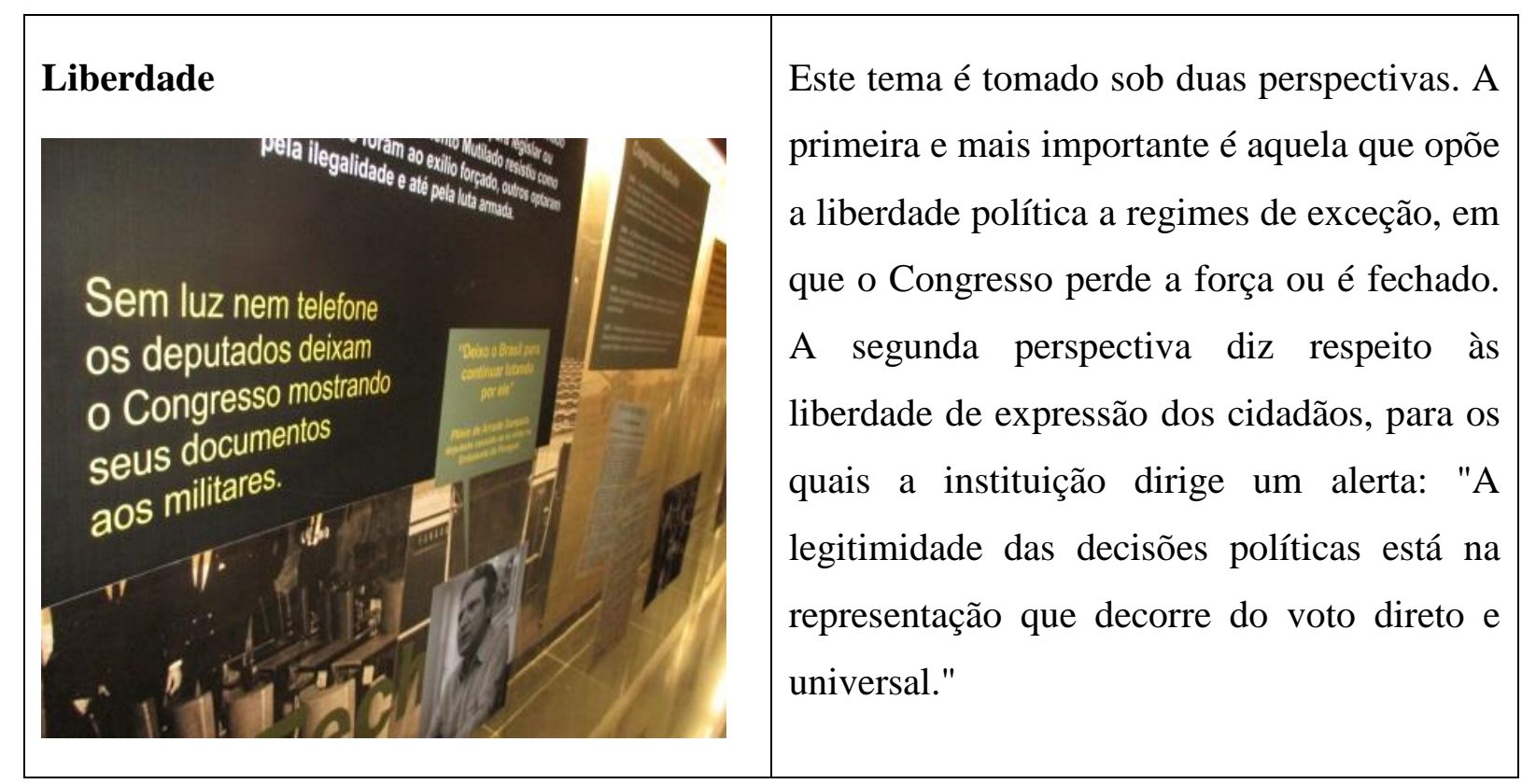

\begin{tabular}{|c|c|}
\hline 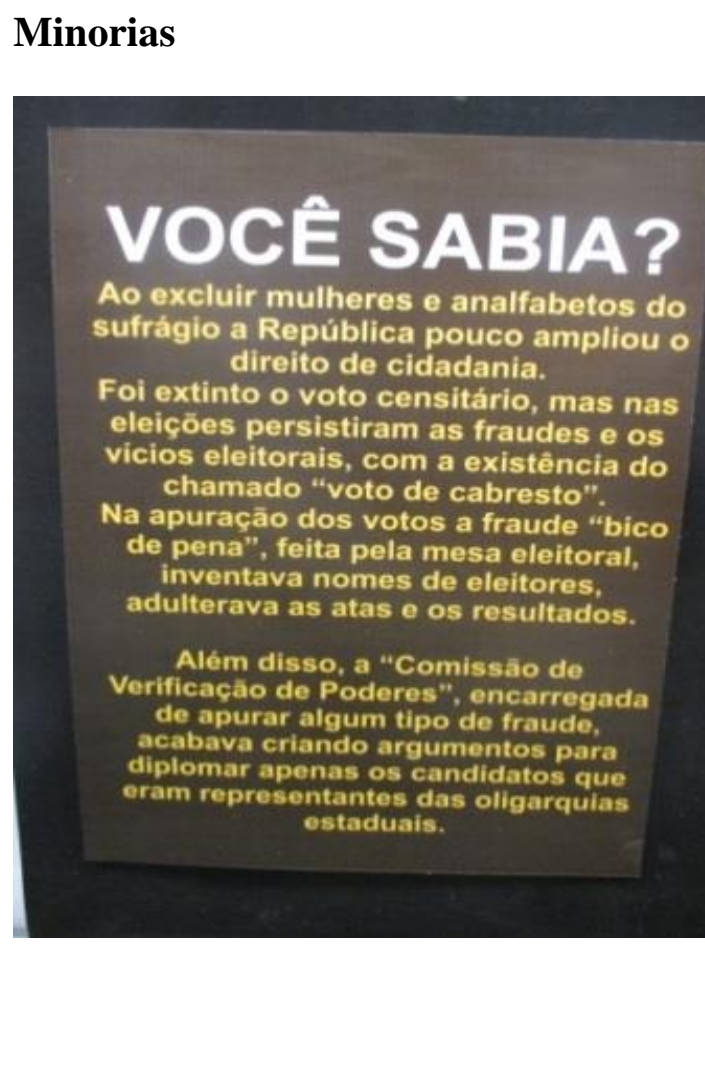 & $\begin{array}{l}\text { Por não ter recebido maior relevo nos textos } \\
\text { do corpus, entende-se que não representa } \\
\text { enfoque da ação política do grupo } \\
\text { hegemônico. Muito embora tenha sido } \\
\text { dedicada parte da exposição para tratar da } \\
\text { luta das mulheres por direito político, } \\
\text { praticamente não há referências intertextuais } \\
\text { das mulheres como autoridades políticas, } \\
\text { personalidades históricas ou tradicionais, } \\
\text { ligadas à área filosófica, artística ou literária, } \\
\text { a referendar a importância da democracia e a } \\
\text { referência ao Parlamento. A referência à } \\
\text { mulher, enfim, é marginal e atrelada, por } \\
\text { exemplo, à participação política dos } \\
\text { analfabetos e escravos. }\end{array}$ \\
\hline
\end{tabular}




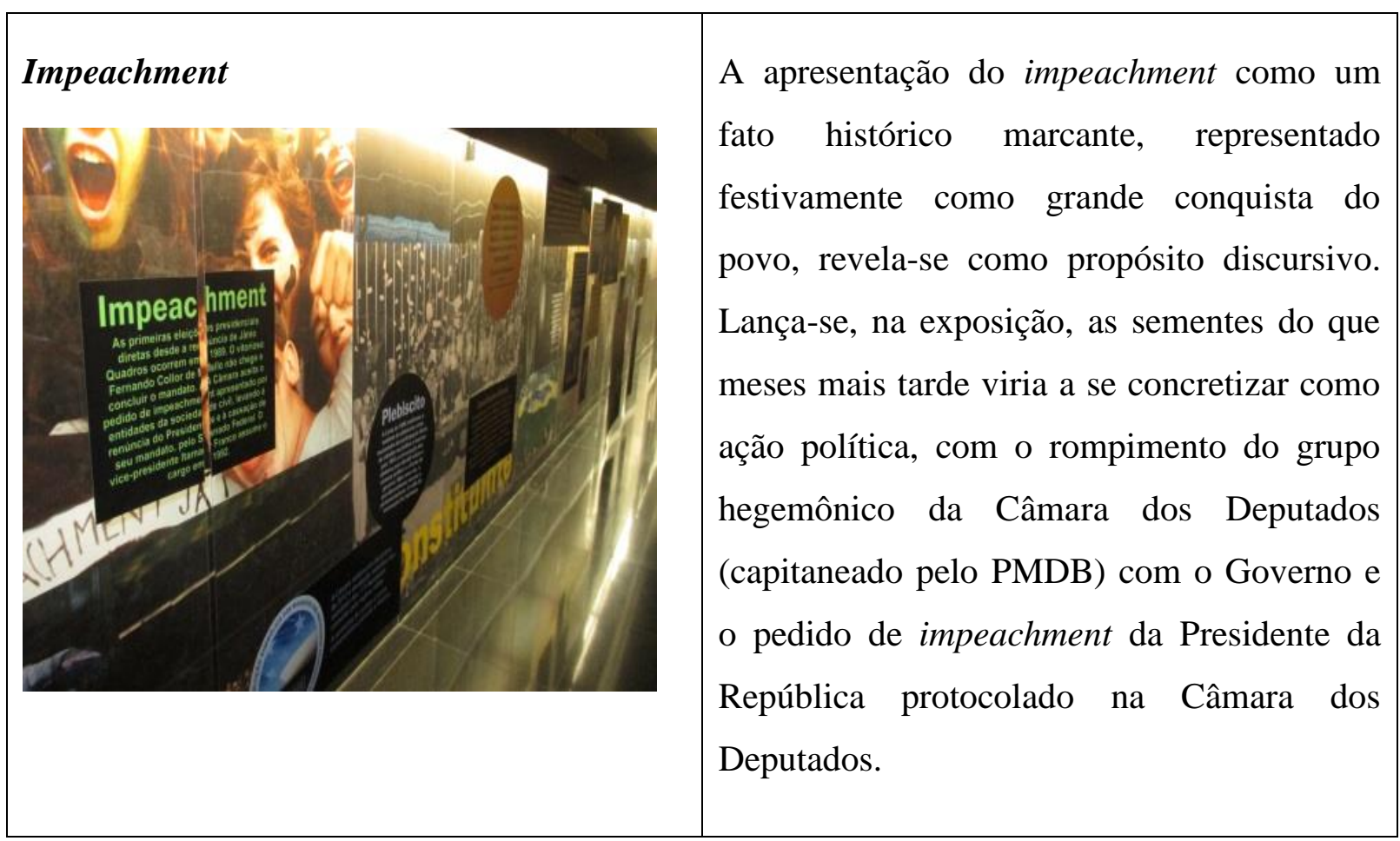

Investigados os lugares de fala dos participantes discursivos, passamos ao segundo passo proposto por Kress (1989) para a investigação do gênero, a análise dos elementos componentes da organização textual.

\subsubsection{Dos elementos componentes da organização textual}

\subsubsection{Análise discursiva crítica e multimodal da capa e da contracapa do prospecto}

O prospecto da exposição que ora analisamos foi produzido pela Secom com o emprego de texto escrito e imagem. Como já mencionado, o folder não se dirige aos Deputados, mas ao visitante em geral. Em sua capa, ladeada por imagens de personalidades históricas ilustres da área filosófica, social e política, do Brasil e do mundo (todas personalidades masculinas, vale novamente assinalar), encontram-se em contraste o presente e o passado, representados por duas imagens: acima, o atual Plenário da Câmara dos Deputados, vista de cima; abaixo, em visão frontal, uma pintura que retrata a primeira sessão do Parlamento brasileiro, ainda em Lisboa, em 1822. 
Figura 27 - Capa do folder da exposição Parlamento e Democracia

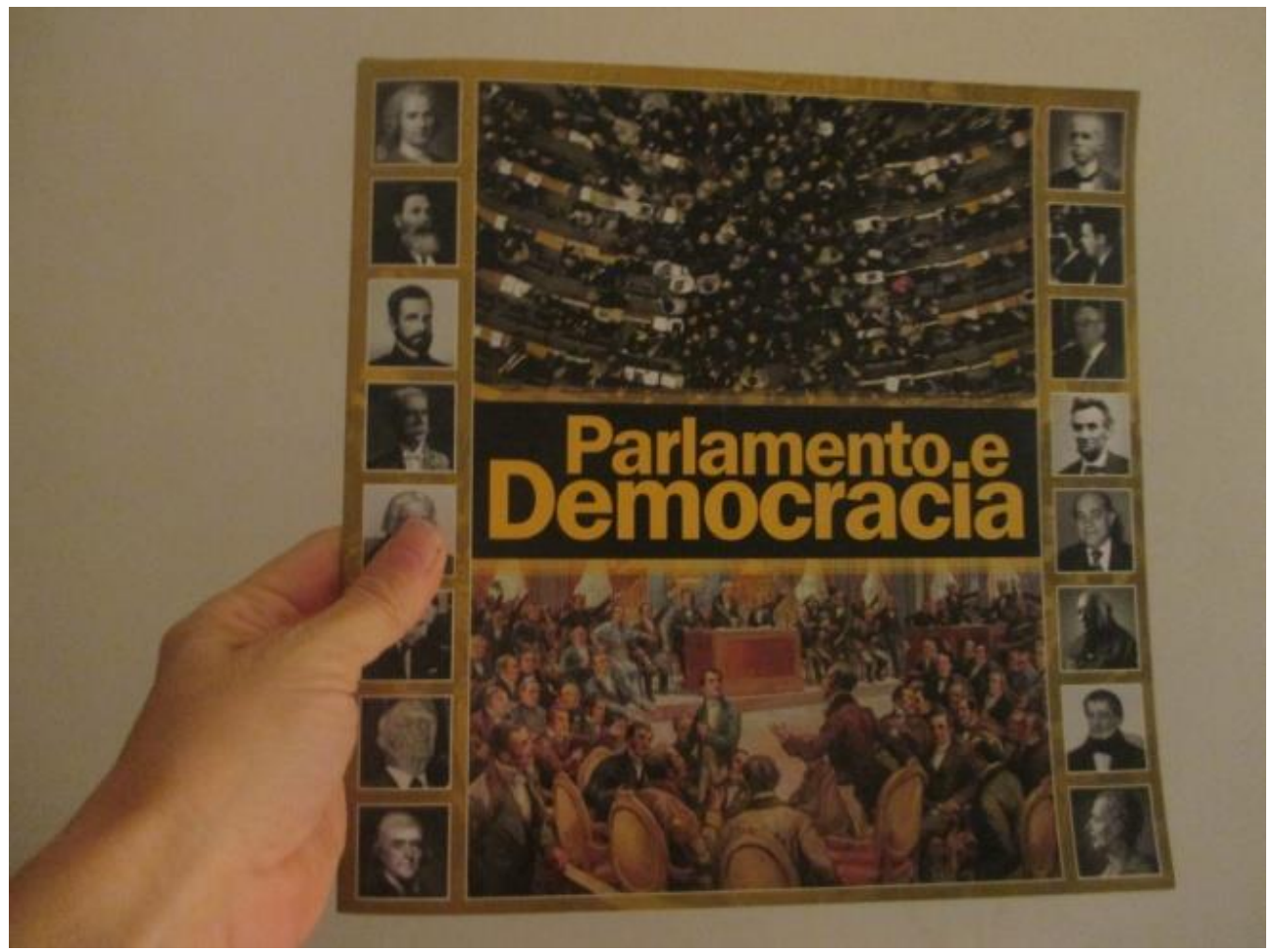

Fonte: Acervo da Câmara dos Deputados do Brasil (2015)

Figura 28 - Parte interna do folder da exposição Parlamento e Democracia

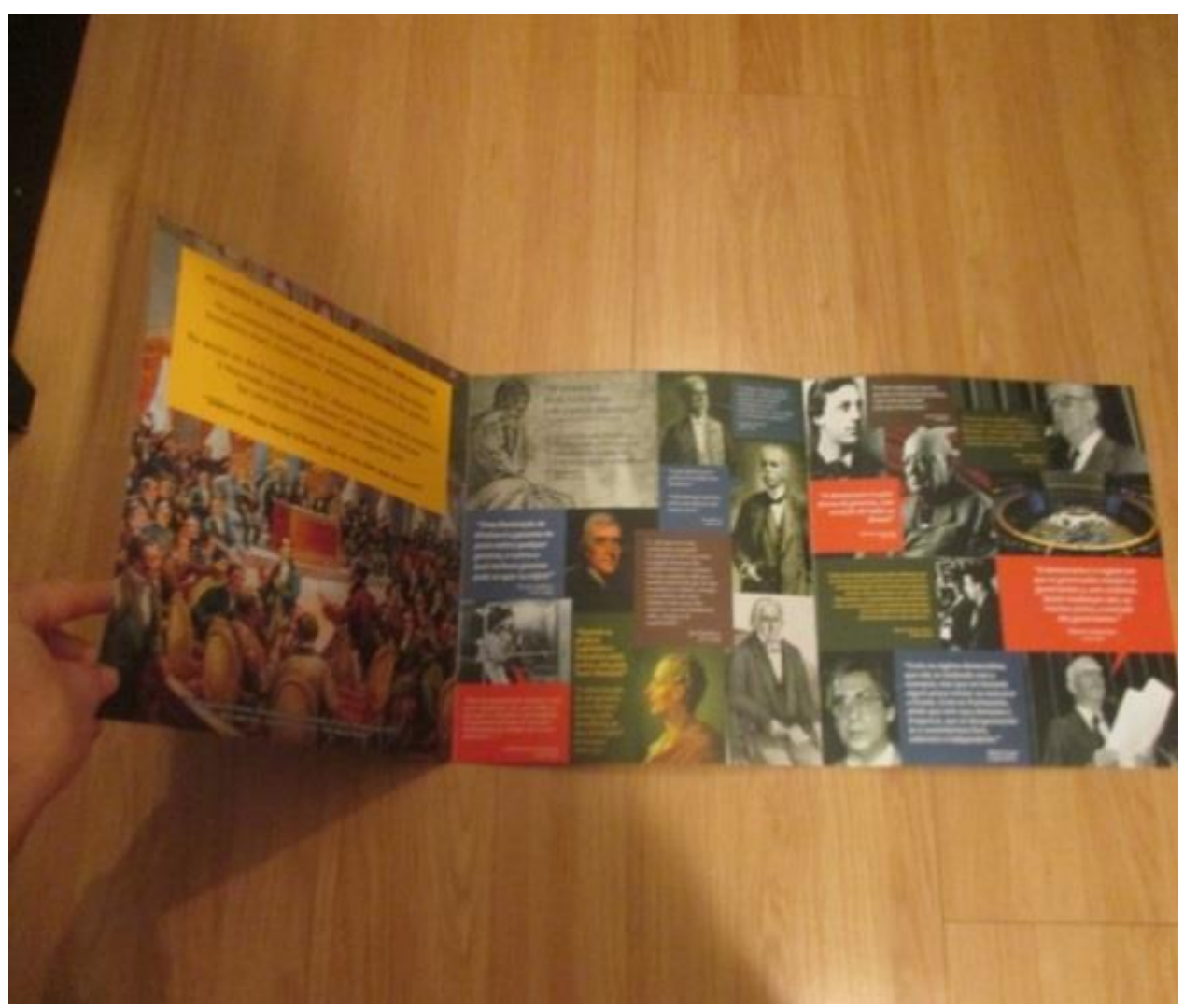

Fonte: Acervo da Câmara dos Deputados do Brasil (2015) 
Kress e van Leeuwen (2006 [1996]) propugnam que o uso da linguagem multimodal, híbrida, que lida com variados recursos semióticos num texto, tende a tornar-se dominante no contexto das vertiginosas mudanças havidas com o estabelecimento da mídia digital e a conseguinte convergência das mídias (MARTIN-BARBERO, 2004).

Conforme já aduzimos, a convergência das mídias impôs mudanças à linguagem verbal e não verbal, no âmbito tanto da produção quanto da distribuição dos textos (prática discursiva). No que concerne à distribuição, não obstante seja a Secom responsável pela produção dos textos institucionais midiáticos exarados pela Casa de Leis, buscando assegurar que a linguagem empregada dará conta do fenômeno da convergência das mídias, aquela Secretaria não tem domínio nem poder sobre todos os media de comunicação por que percorrem os textos que produz, após serem originariamente veiculados por seus órgãos midiáticos, tampouco pode exercer algum controle sobre as alterações consequentes de posteriores recontextualizações ou delocações (FAIRCLOUGH, 2006) desses textos.

Vieira e Silvestre (2015, p. 23) entendem que, para Poster (1996 apud VIEIRA; SILVESTRE, 2015, p. 24), a linguagem sujeita-se a uma reconfiguração, que ocorre na seguinte situação:

[...] no momento que determinado evento discursivo é mediado por outro meio, como, por exemplo, quando um discurso é proferido diante das câmeras da TV e depois esse mesmo discurso é colocado na internet ou publicado nos jornais do país [...].

Esse fenômeno é tratado por Iedema (2003) em termos de ressemiotização, que seriam as mudanças na linguagem ocasionadas pela mudança dos media de difusão. Daí resultariam combinações textuais híbridas.

Relembramos o entendimento de Fairclough (2006) quanto à importância da recontextualização, considerada pelo autor como a principal fonte de mudança na linguagem. A recontextualização concretiza-se em hibridismos intertextuais e interdiscursivos - sem que se perca de vista a dialética entre ordens de discurso e a prática discursiva ou o evento discursivo (FAIRCLOUGH, 2001, p. 126). Notamos, em toda a exposição e em seu folder, a recorrência de recontextualização, relacionada ao intertexto e ao interdiscurso.

Eis detalhes do folder, cujos significados semióticos escrutinamos. 
Figura 29 - Folder da exposição Parlamento e Democracia

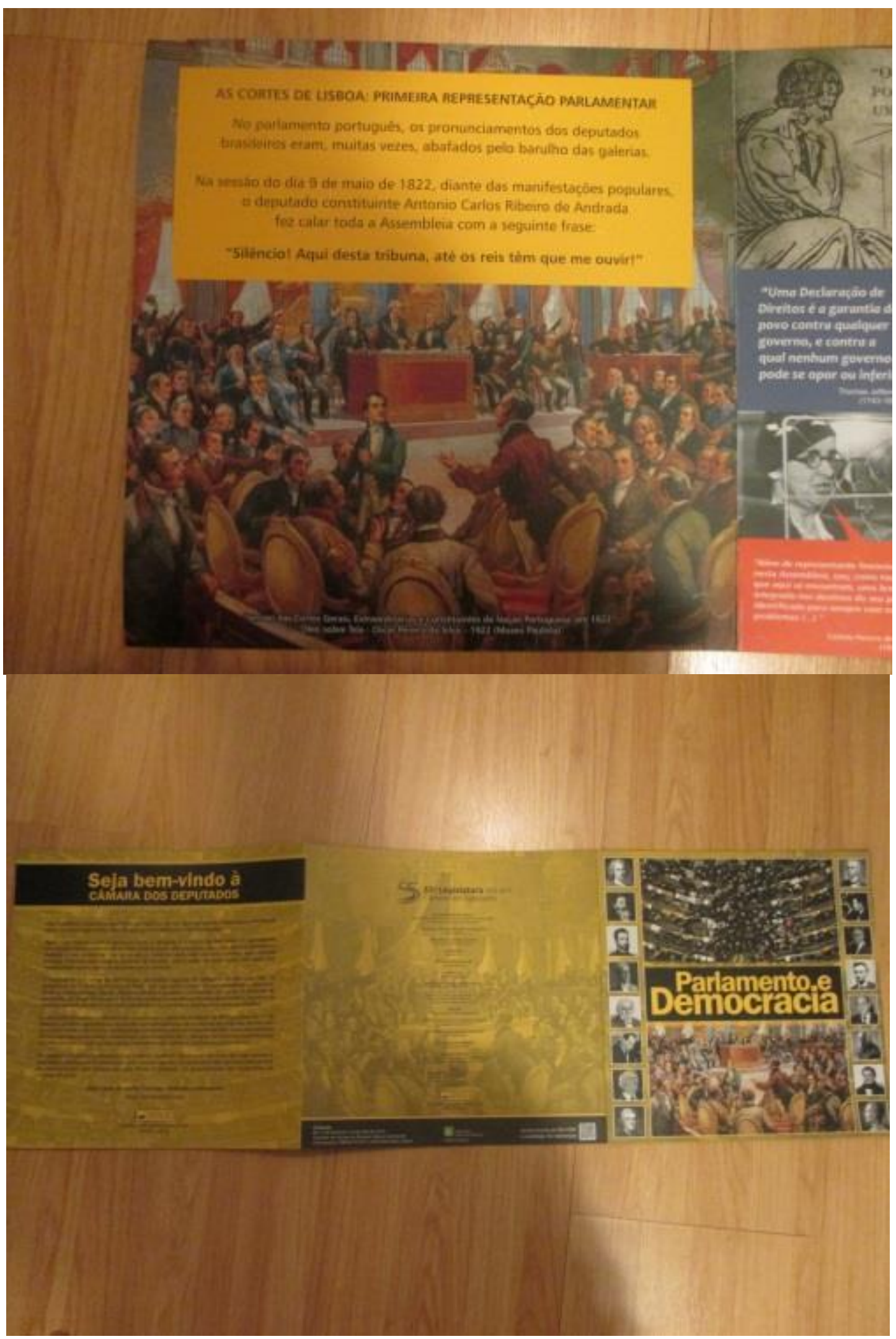

Fonte: Acervo da Câmara dos Deputados do Brasil 
Ao enfocar o significado representacional (KREES; VAN LEEUWEN, 2006), de acordo com a análise proposta pela Gramática do Design Visual (GDV), na imagem — como, de resto, em todo ato semiótico — os participantes podem ser interativos (participam do ato comunicativo, como o sign-marker/viewer, o escritor/leitor, v.g.) ou representados (pessoas, lugares ou coisas). Reconhecem-se imagens como estruturas narrativas (e não conceituais) pela presença de um vetor (Ibid., p. 59) que conecta os participantes representados e expressa o tipo de relação retratada entre estes, o que estão fazendo ou o que está acontecendo.

Nas figuras abaixo, pode-se apontar o processo narrativo com base na multiplicidade de vetores originários de braços estendidos (actors) que apontam para outros participantes, tanto pessoas quanto coisas (no caso, goals), ou simplesmente para o alto ou algo que não se vê (ação não-transacional). O processo representa o alvoroço do momento, que ficou registrado nos Anais da história. Há também vetores que emanam da linha dos olhos dos participantes representados (processo narrativo reacional) em direção a outros participantes (caracteriza a transacionalidade do processo narrativo).

Figura 30 - Reprodução de óleo sobre tela, de Oscar Pereira da Silva, 1922 (Museu Paulista), como detalhe da parte interna do folder da exposição Parlamento e Democracia.

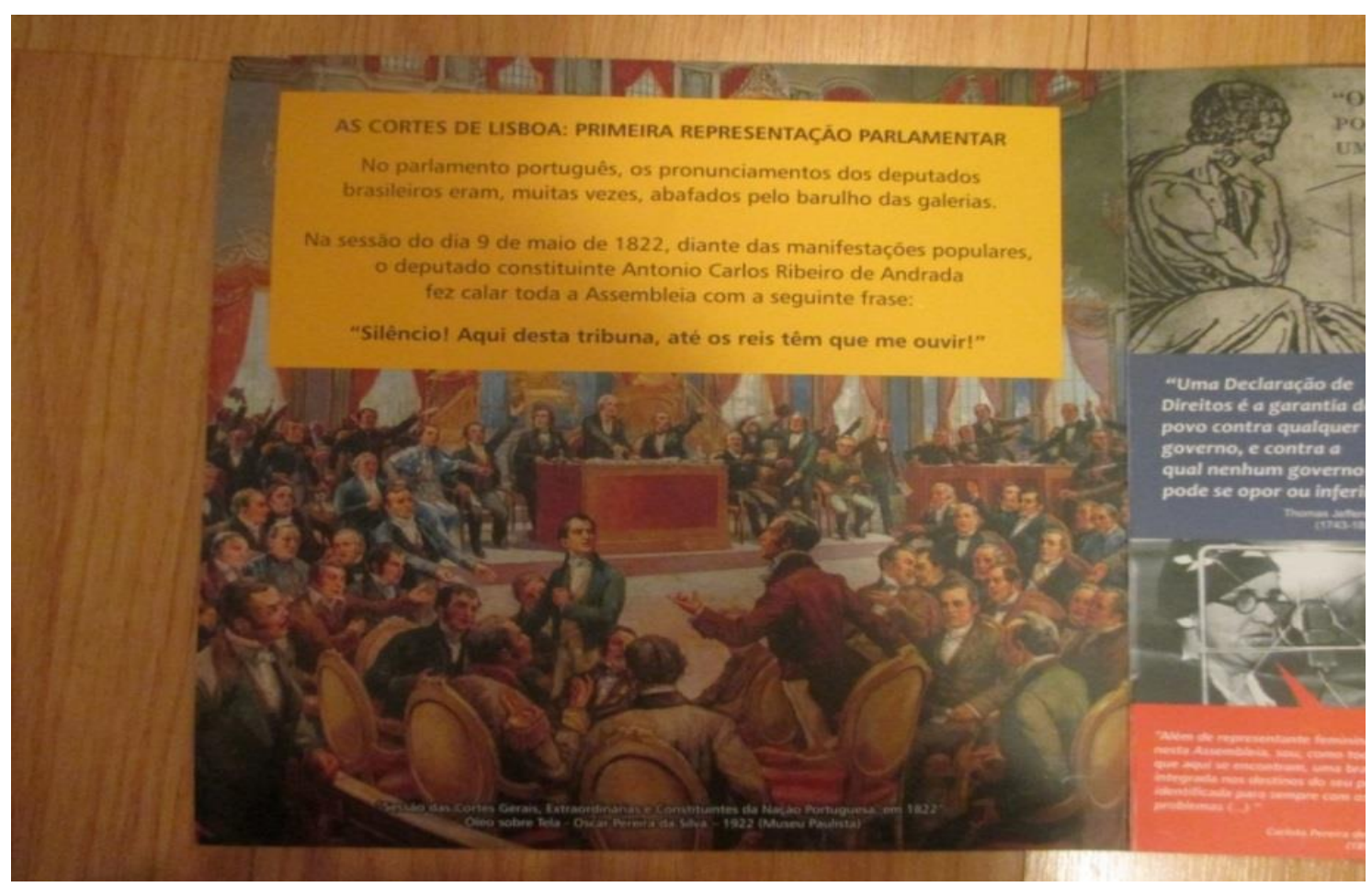

Fonte: Folder da exposição Parlamento e Democracia (Acervo da Câmara dos Deputados). 
Figura 31 - Reprodução de óleo sobre tela, de Oscar Pereira da Silva, 1922, vetorizada.

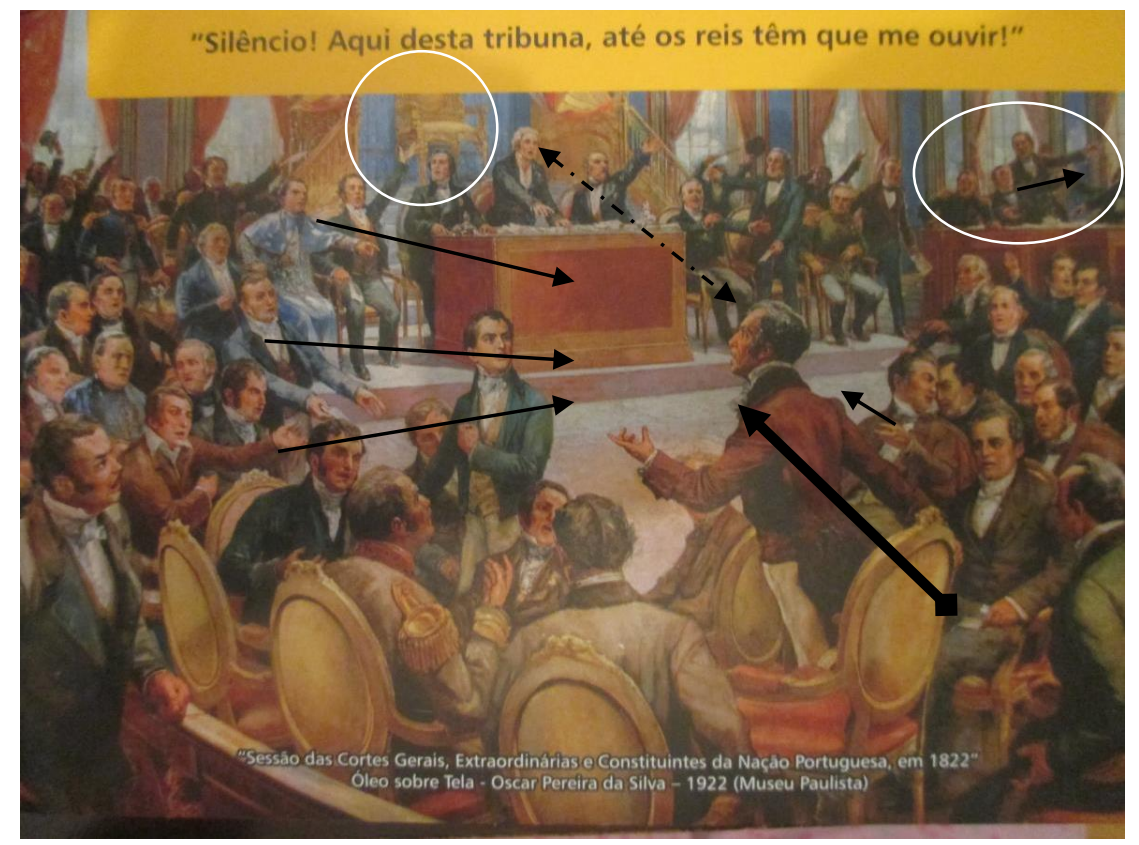

Fonte: Folder da exposição Parlamento e Democracia (Acervo da Câmara dos Deputados)

Outros vetores direcionam-se a um participante de pé, na tribuna à direita, chamando a atenção do viewer/leitor para um participante que representa um político de oposição, de maior prestígio, certamente um parlamentar europeu. Note-se que a maioria dos reacters convergem o olhar para o participante foco do processo narrativo (phenomenon), que se ressalta pela vestimenta avermelhada, similar à cor da mesa diretora. Kandinsky (1925), em sua Gramática das Cores, relaciona a cor vermelha à impulsividade e à raiva, entre outros sentimentos. Kress \& van Leeuwen (2006) repercutem esse entendimento e apontam o vermelho como importante recurso semiótico de saliência.

Na pintura, entre o parlamentar brasileiro e o presidente da mesa diretora, que trocam recíprocos olhares, constrói-se uma estrutura transacional bidirecional (os participantes principais são atores e alvo, ao mesmo tempo), tornando-os os participantes principais da narrativa. Os corpos dos participantes principais consistem, eles próprios, em vetores. De pé, seus corpos tendem ao centro vazio do plenário, por cuja ocupação lutam discursivamente os querelantes, no campo da batalha política. 
Eis o traslado do texto sobrescrito à imagem da pintura:

AS CORTES DE LISBOA: PRIMEIRA REPRESENTAÇÃO PARLAMENTAR

No parlamento português, os pronunciamentos dos deputados brasileiros eram, muitas vezes, abafados pelo barulho das galerias.

Na sessão do dia 9 de maio de 1822, diante das manifestações populares, o deputado constituinte Antonio Carlos Ribeiro de Andrada fez calar toda a Assembleia com a seguinte frase:

"Silêncio! Aqui desta tribuna, até os reis têm que me ouvir!"

E este é o texto no modo escrito — a legenda da foto — sobreposto à pintura:

"Sessão das Cortes Gerais, Extraordinárias e Constituintes da Nação Portuguesa, em 1822"

Óleo sobre Tela - Oscar Pereira da Silva - 1922 (Museu Paulista)

O texto que ocupa o cluster superior sobreposto à imagem se alinha ao sentido construído na imagem. Naquele momento, os de menor prestígio, os parlamentares brasileiros, fizeram-se ouvir, calando "toda a Assembleia com a seguinte frase: 'Silêncio! Aqui desta tribuna, até os reis têm que me ouvir!”. Faz-se presente, neste texto como em toda a exposição, o princípio da integração dos recursos semióticos.

Relevante notar que, com rara exceção, as bocas dos parlamentares retratados encontram-se abertas, e não se vê parlamentar que não esteja em movimento (levantando-se, andando, movimentando os braços para o lado e para cima). A intenção de mostrar que os Parlamentares se movimentam e trabalham arduamente remanesce como uma constante nos textos verbais e não verbais produzidos pelo Parlamento brasileiro. Durante muito tempo, o Jornal da Câmara utilizava tão somente fotos de parlamentares em close, com a boca aberta diante de microfone, nas tribunas do Parlamento. Com a expansão do fenômeno da multimodalidade (entre outros fenômenos sociais e linguísticos relevantes), a linguagem 
modificou-se, de tal modo que hoje as páginas atuais do jornal aproximam-se, em todos os aspectos semióticos, às dos diários e revistas comerciais.

Nesse intento, a integração dos sentidos construídos pela comunhão dos modos semióticos eleitos para a composição do folder se escancara. Assim se inicia o texto principal (grifo nosso): “Aqui trabalham brasileiros escolhidos por cada um de nós...” A imagem e o texto, neste caso, convergem para o mesmo propósito discursivo, reforçando-se mutuamente em termos de significado construído.

Ainda dentro da análise dos processos narrativos, vale assinalar marca textual que pode caracterizar o fenômeno da hibridização genérica - e da presença de intertextualidade (FAIRCLOUGH, 2001). Existem balões desenhados que se conectam às fotografias (e à imagem, no caso de Aristóteles). Nota-se que os usuais "balões" ou formas elípticas que se utilizam originalmente em revistas em quadrinhos para enquadrar as falas das personagens, foram transformados em quadrados ou retângulos, numa aproximação às formas dos clusters de páginas virtuais que se sobrepõem, em contribuição à estética do folder e de toda a exposição, mas primordialmente ao intento de aproximação com o viewer/leitor jovem (o que ocupa as manifestações populares).

Esse intento de buscar cumplicidade com o leitor, por meio da interdiscursividade ou intertextualidade constitutiva, ou seja, por meio de elementos componentes da organização textual, denuncia a hibridização genérica (forma e propósitos híbridos). Ao mesmo tempo, testemunha a tendência, apontada por Fairclough (2001) para o Novo Capitalismo, de conversacionalização do discurso.

O tipo de vetor que faz emanar da boca dos oradores as suas respectivas falas (e não os seus pensamentos, pois no Parlamento a tônica é a oratória) é analisado por Kress e van Leeuwen (2006, p. 68) como elemento do processo narrativo (speech process, não mental process, neste caso), o que Halliday (1985) aponta como um tipo de projective structure. Para os autores da multimodalidade, os "balões" são recursos multimodais que fazem a mediação entre o speacher (orador) e o content (fala).

Diante da riqueza das construções semióticas do nosso objeto de análise, concentrarnos-emos apenas em alguns aspectos composicionais mais notáveis, pelo significado representacional que da imagem fazem emergir. Dos participantes secundários 
(circunstâncias), destacam-se as mesas ao centro e na lateral direita. A mesa diretora, ao centro e elevada um degrau acima, guardada pelos representantes das Armas e da Igreja, representa-se como local em que se detém o poder hegemônico.

Neste detalhe, avocam-se outros subtipos de padrão sintático distinguidos por Kress e van Leewen (1996 apud JEWITT; OYAMA, 2004, p. 144), como a aparência visual dos atores sociais, entre vestuário, cabelo, postura, expressão facial. Ao lado da mesa diretora, por seus vestuários e acessórios, podem-se indicar os representantes das ordens religiosas e militares, que se encontram à esquerda (representa potencialmente a informação dada, conhecida, não questionável) e na parte superior da imagem (representa a informação ideal, sacralizada).

A mesa lateral direita — posição que permite atribuir à circunstância (participante representado) uma posição política conservadora e tradicionalista - é ocupada por Parlamentares portugueses, vestidos de preto, cor que revela eminência e nobreza. A mesa dos parlamentares europeus encontra-se na mesma linha da Mesa Diretora, alinhada na relação de poder.

A cadeira do Rei, contudo, encontra-se vazia. Em posição elevada e ao centro, representa o abstrato, quimérico, umbrático, inexistente (assim, também, inútil). O rei, ausente dos debates, faltoso, alheio aos clamores da Assembleia, recontextualiza-se na história presente para representar o Poder Executivo ou Governo, a quem se dirige a crítica do grupo hegemônico da 55 ${ }^{\mathrm{a}}$ Legislatura da Câmara dos Deputados. Aproximam-se os mandatários do voto popular aos seus representantes, ao mesmo tempo em que posiciona o Governo do lado oposto, contraposto — assim se posiciona na pintura — , representando-o como rival ou inimigo.

Não é de se estranhar, na retratação do Parlamento português de 1822, a ausência de representação de participantes mulheres, mas certamente é digna de nota, questionável e relevante a ausência da representação feminina na exposição Parlamento e Democracia. Não obstante ter sido dedicada uma parte da exposição para citar a inserção da mulher na política e no Congresso - ao lado de outras minorias —, praticamente não há mulheres figurando como participantes representadas, à exceção da menção a uma única Deputada. 
Vale dizer, também, que a parte da exposição dedicada às mulheres apresentou-se na quina da parede, ao fim do corredor, na cor amarelo esmaecida, atrás do aparelho televisivo que passava incessantemente o documentário sobre a história do Parlamento e da Democracia. Disputando com o televisor a atenção do visitante, o espaço dedicado às mulheres e outras minorias perdeu a disputa, ainda que ambos estivessem ocupando local desprivilegiado na distribuição espacial da mostra histórica.

Figura 32 - Fotos de textos multimodais sobre a luta das mulheres pela cidadania, extraído da exposição Parlamento e Democracia
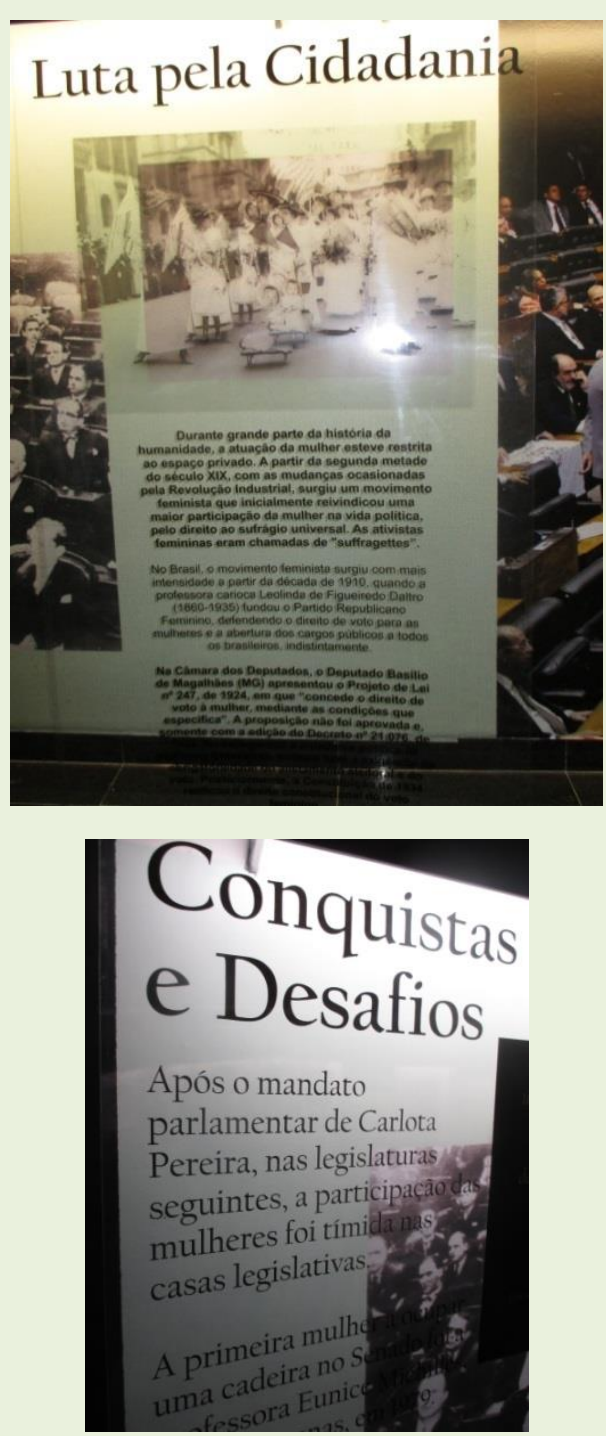
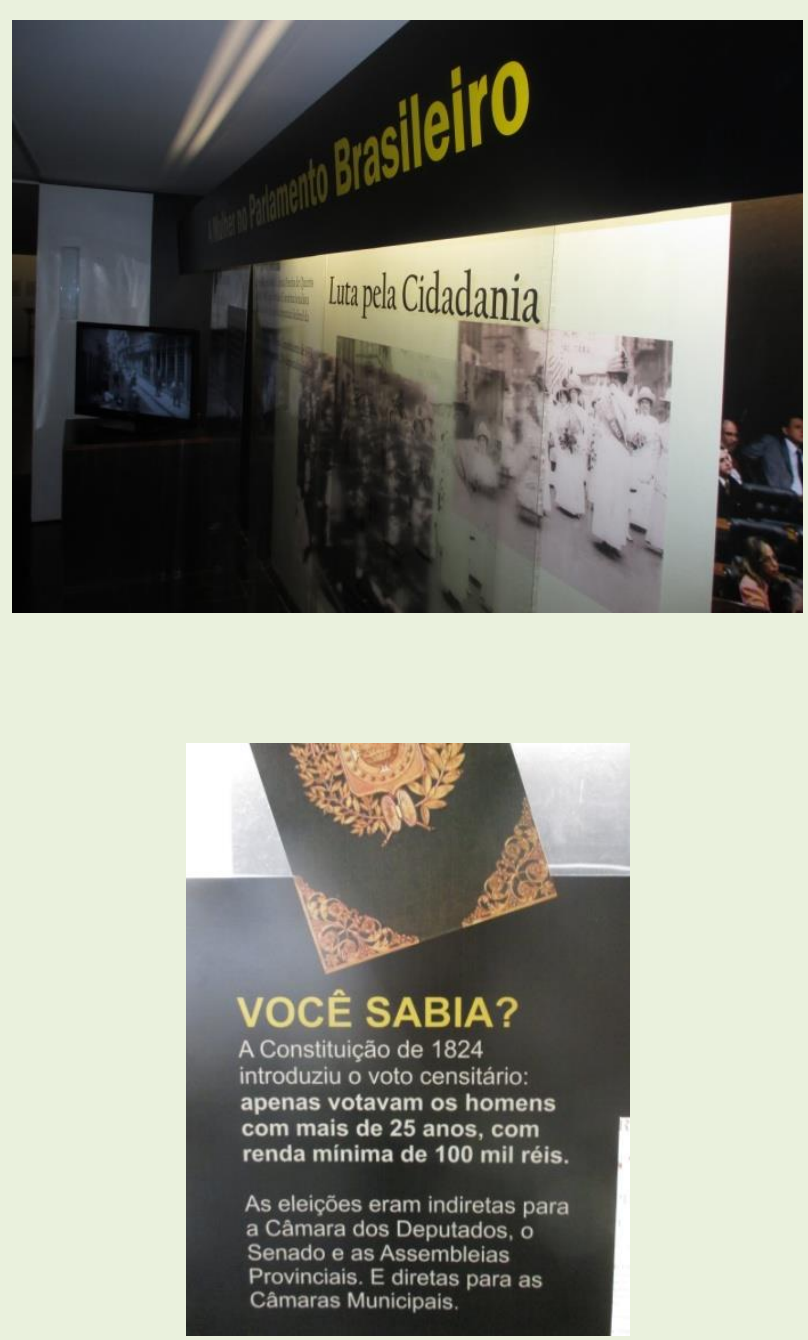

Fonte: Acervo pessoal da autora, da exposição Parlamento e Democracia. 
Ademais, a ausência se nota em praticamente todo o prospecto da exposição. Por ser a exposição um produto atual do Parlamento, a quase ausência de voz feminina entre as personalidades históricas retrata o descompromisso político com esse segmento social. Devese mencionar, contudo, a inserção acanhada de foto e de fala da Deputada Carlota Pereira de Queirós (Figura 27) no prospecto, em posição desprivilegiada no que diz respeito às potencialidades semióticas da construção do sentido composicional: aparece embaixo, à margem, à direita, em preto e branco, como mostra a figura abaixo.

Figura 33 - Retrato da figura da Deputada Carlota de Pereira de Queirós no folder da exposição Parlamento e Democracia

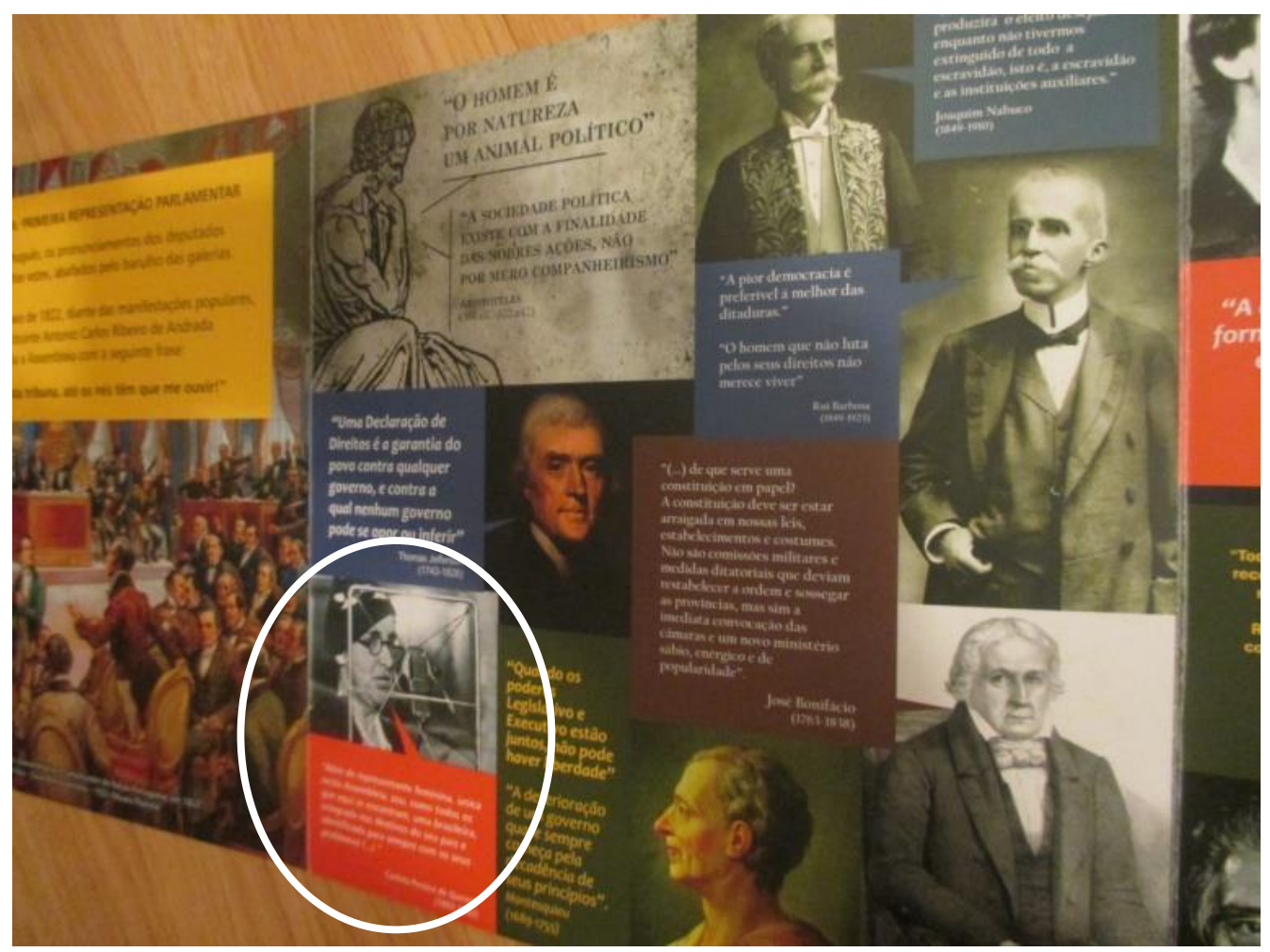

Fonte: Acervo da Câmara dos Deputados do Brasil.

Escondida atrás de um imenso microfone, chapéu e óculos, com os cabelos presos, masculinizada, a Parlamentar simboliza a pífia representação feminina no Parlamento hodierno: apenas 45 Deputadas, contra 468 Deputados (menos de 10\%), num país em que 52\% dos eleitores são mulheres. Em 2003, 53 Deputadas foram eleitas. Após 12 anos, o número de mulheres eleitas para a Câmara dos Deputados diminuiu. Não se pode deixar de 
assinalar o descaso ou descompromisso com uma possível mudança dessa situação assimétrica de representação parlamentar. Ratifica tal entendimento a derrota sofrida pela Bancada Feminina no Congresso, na reforma política ocorrida em junho de 2015, quando não se conseguiu garantir sequer a obrigatoriedade de representação de $10 \%$ de mulheres no Parlamento. Vale assinalar que cinco Estados da Federação (Alagoas, Espírito Santo, Mato Grosso, Paraíba e Sergipe) não elegeram sequer uma deputada nas eleições de 2014.

Nem mesmo na parte da exposição histórica dedicada à abolição da escravatura se dá relevo ao papel feminino. Poder-se-ia argumentar que, como se enfoca o Parlamento e seus membros, não se haveria de dedicar maior atenção à regente Princesa Isabel, nominada na mostra. Mas, em verdade, as autoridades históricas representadas não são somente parlamentares, mas incluem até escritores e artistas. A ausência da retratação feminina permanece, de fato, eloquente no que diz respeito ao posicionamento político-ideológico e ao sectarismo do produtor do signo.

Nas imagens da página seguinte, mostra-se o destaque para a atuação do Parlamento em relação à abolição da escravatura. 

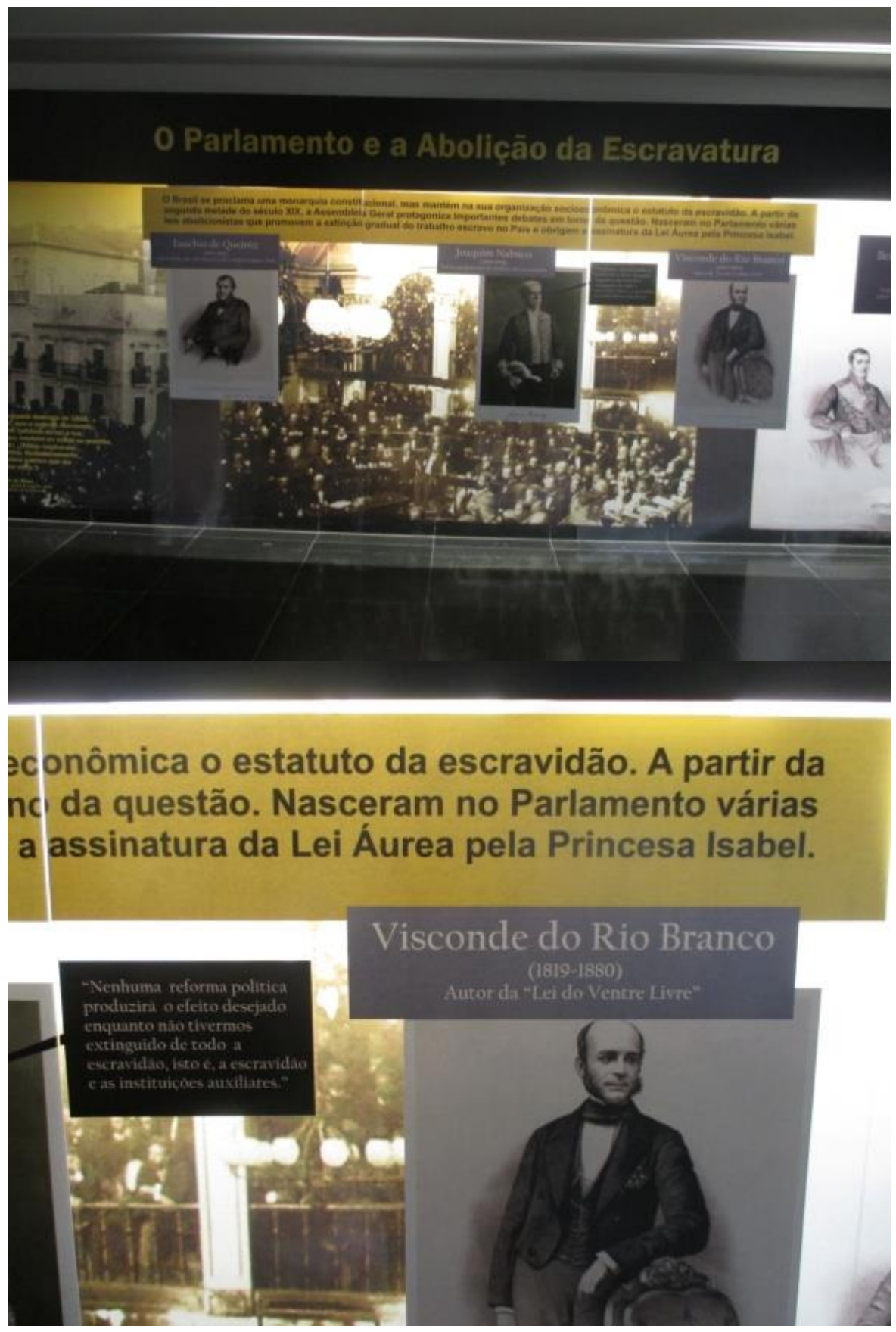

Fonte: Acervo pessoal da autora (foto da exposição Parlamento e Democracia).

Ao construir o significado interativo, as imagens podem criar relações singulares entre os observadores e o mundo representado pelo sign-maker, relações que podem ser descortinadas por meio da análise do contato, da distância e do ponto de vista que se estabelece em relação a ambos. 
Os olhares diretos, voltados ao viewer, nos retratos de Thomas Jefferson, José Bonifácio e Mário Covas, estabelecem com o cidadão observador/leitor um contato imaginário e compõem o que Kress e van Leeuwen (1996), inspirados em Halliday (1985), chamam de offer pictures, em que o participante representado simbolicamente faz uma declaração ou oferece informação (ou bens e serviços) ao viewer/reader.

Figura 35 - Página interna do folder da exposição Parlamento e Democracia

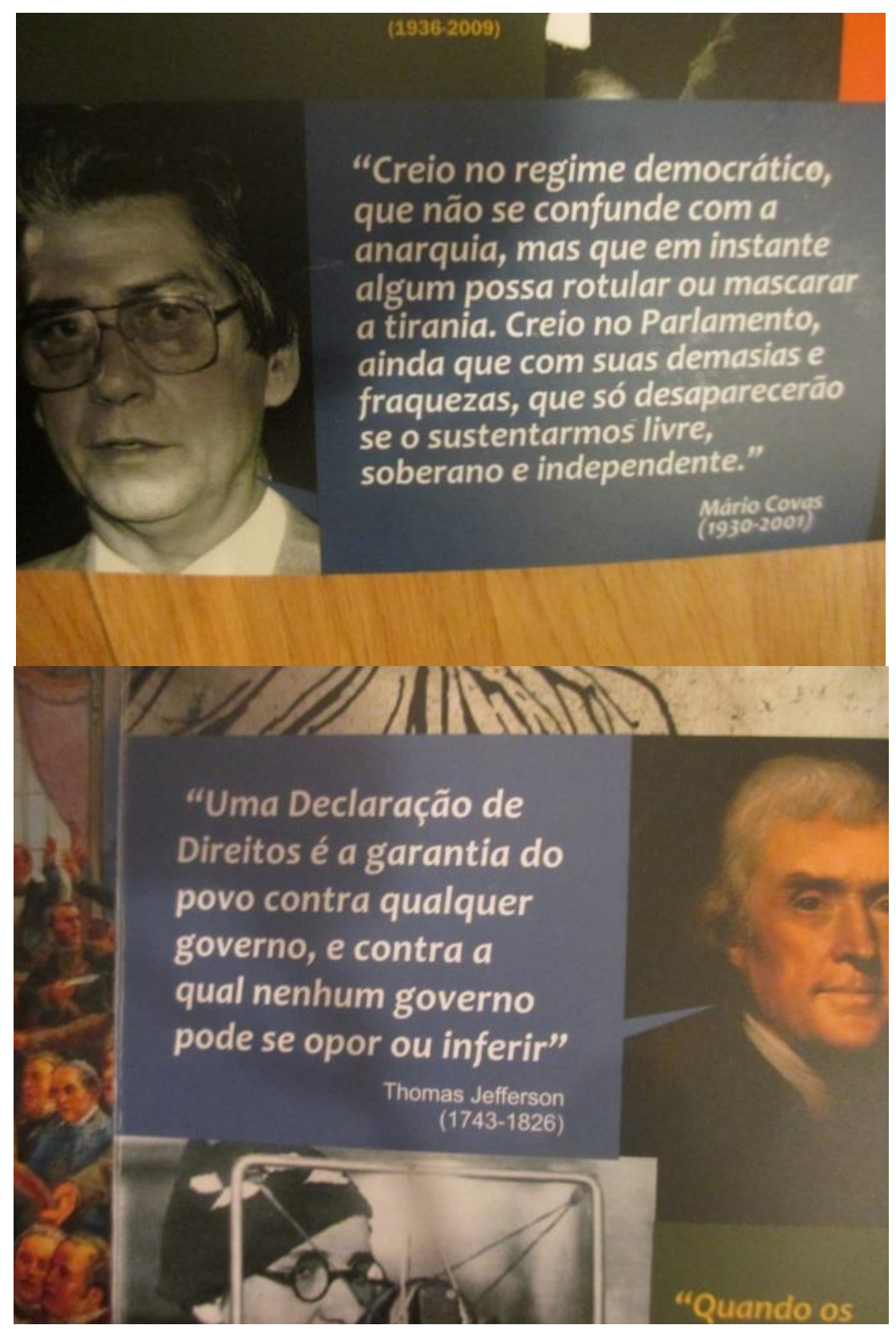

Fonte: Acervo da Câmara dos Deputados 
Poderiam também demandar algo do observador, simbolicamente, por meio de demand pictures. Assim o faz o texto escrito, com o emprego de injuntivos: "Entre. Veja. Pesquise. Conheça. Defenda o Parlamento." O significado se constrói por meio de um e outro recurso semiótico, conformando a força perlocucionária do texto (AUSTIN, 1998). Ambas as opções (demand or offer pictures) buscam aproximar os visitantes da exposição aos Parlamentares, ao Parlamento e àqueles que o defendem.

O intento de criar intimidade, condescendência e cumplicidade explicita-se na escolha de retratos e figuras dos participantes representados em close (cabeça e ombros, prevalentemente), conforme a categoria de análise chamada distância (JEWITT; OYAMA, 2004, p. 146). O propósito de aproximação com o cidadão viewer/leitor deixa marcas também na linguagem verbal, em que se flagra a tendência à informalidade e democratização da linguagem (FAIRCLOUGH, 2001, 2003): "Seja bem-vindo à Câmara dos Deputados"; "discussões que varam a madrugada"; "qualquer regime que cale a voz das ruas [...] merece repúdio"; "Esta Casa também é sua”. Integram-se os recursos semióticos, complementandose, neste caso, na construção do significado.

Ademais, o texto da contracapa busca contrapor-se às constantes manifestações populares, mas também às tentativas de invasão do prédio da Câmara dos Deputados, das galerias das comissões temáticas e do plenário. As manifestações havidas em todo o Brasil, em junho de 2011, tornou-se marco na história do País e do mundo, a qual o sociólogo Manuel Castells (2013) investigou em sua obra Redes de Indignação e Esperança: movimentos sociais na era da internet. Quando se ressalta no folder que "os pronunciamentos dos deputados brasileiros eram, muitas vezes, abafados pelo barulho das galerias" e que, “diante das manifestações populares, o Deputado constituinte fez calar toda a Assembleia”, intenta-se, por metáfora (FAIRCLOUGH, 2003), dizer que o lugar apropriado para se manifestar é o Parlamento, mas por meio dos representantes do povo, pois, daquelas tribunas, "até os reis" têm que ouvi-los. Enfim, roga-se veementemente ao povo que, este sim, faça "Silêncio!". Vale lembrar, a favor dessa interpretação, que o prospecto se dirige ao visitante em geral, ao cidadão, enquanto a exposição dá as boas-vindas aos Parlamentares.

Na exposição, uma imagem mostra-se bastante representativa deste intento de alertar o cidadão quanto ao risco das convulsões populares. Imagens de manifestações populares aparecem por trás da expressão "congresso fechado", escrita em letras garrafais. Assim, o que estaria "por trás" do fechamento do Congresso (consequência, efeito) seriam as manifestações 
do povo (causa, explicação). O Princípio de Integração dos Recursos Semióticos, neste caso, manifesta-se com eloquência magnânima.

\section{Figura 36 - Manifestações populares e Congresso fechado: foto da exposição Parlamento e Democracia.}

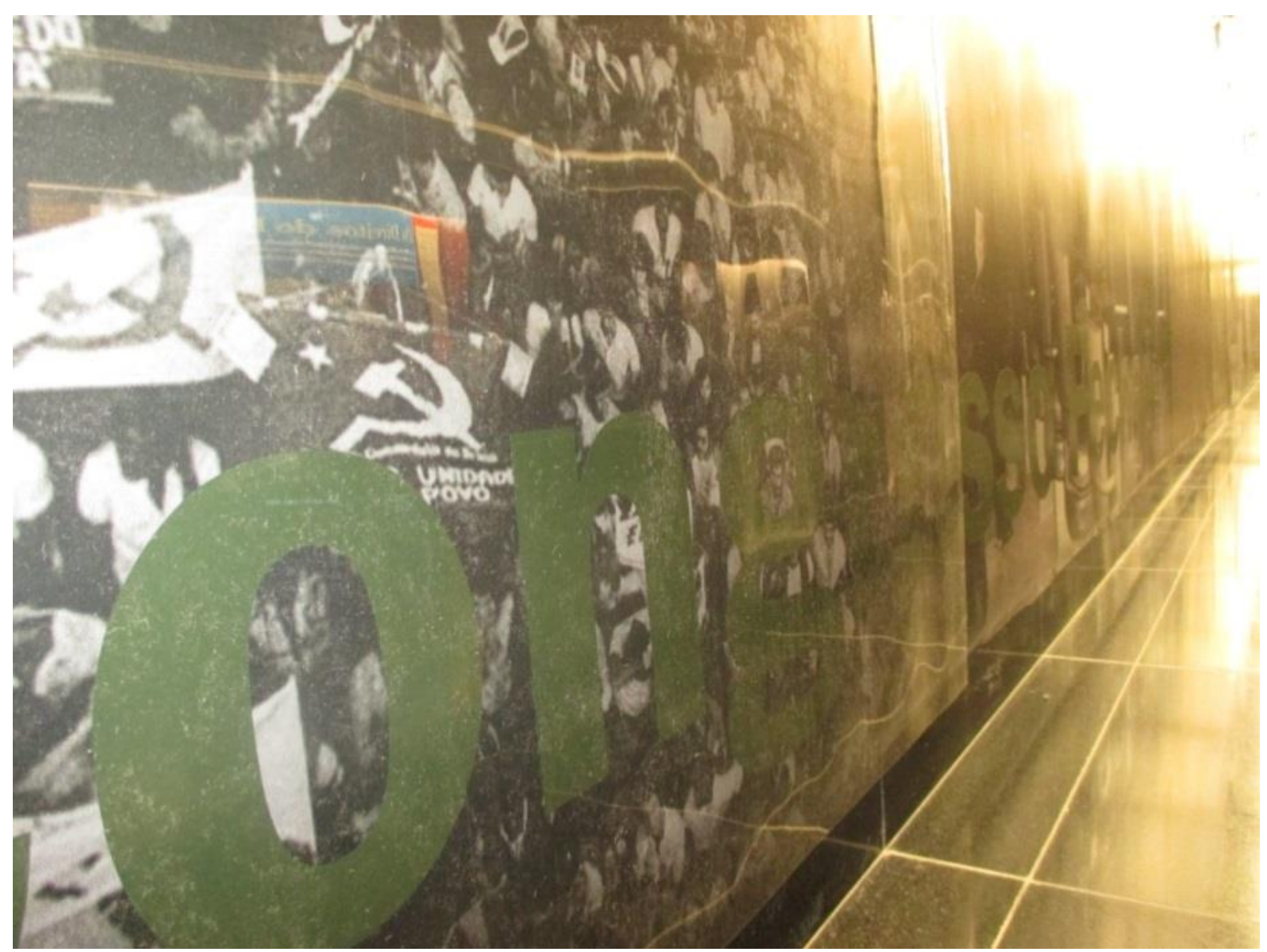

Fonte: Foto do acervo pessoal da autora.

O símbolo do Partido Comunista do Brasil (foice e martelo), que aparece no entremeio das manifestações populares retratadas, insere-se na interpretação mencionada. Não se trata aqui, como se poderia inferir de uma observação perfunctória, menção positiva. Atrela-se à esquerda comunista a situação considerada execrável: a decretação de um regime de exceção, com o fechamento do Congresso. Assim, quando há menção à esquerda política, raras menções, estas se apresentam relacionadas a eventos sociais não desejáveis.

De volta ao exame da construção do significado interativo nas imagens, aduzimos que os potenciais significados considerados na categoria "ponto de vista" (KRESS; VAN LEEUVEN, 1996, p. 135) podem ser examinados como um tipo de relação simbólica entre produtor/observador da imagem e as pessoas, objetos ou coisas nela representadas. Jewwit e 
Oyama (2004 apud JEWWIT; VAN LEEWEN, 2004, p. 135) elucidam que, considerando o ângulo vertical, o ato de olhar algo de cima posiciona o viewer, simbolicamente, numa situação de poder sobre a coisa vista; ao contrário, haverá um poder simbólico da imagem sobre o viewer que visualiza uma imagem que está acima de seu nível de visão. Uma relação simbólica de igualdade se dá quando o participante representado apresenta-se ao nível do olhar do viewer. Considerando o ângulo horizontal, o olhar frontal implica envolvimento e aproximação, enquanto o ponto de vista lateral coloca o viewer em posição de distanciamento da imagem.

Cumpre assinalar que, por óbvio, a consideração dos ângulos vertical e horizontal comportam gradações. Na capa do prospecto (Figura 31), e também no interior do folder, como já mostramos, há retratos, em close, de autoridades que confrontam de frente o leitor, resultando em uma relação de intimidade com o visitante, uma estratégia de aproximação entre os cidadãos comuns e os notáveis ali retratados, cujas imagens (e relevância histórica) se tomam emprestadas para a defesa do Parlamento e de seus atuais membros.

Jewitt e Oyama (2004) alertam para o fato de que a análise dos pontos de vista possibilita significados potenciais, não necessariamente reais, e que, em verdade, as relações simbólicas podem sugerir uma considerável igualdade social e de poder, enquanto mascaram ou mentem as dissensões sociais e o distanciamento real entre o participante representado e o viewer/leitor. Citam, como exemplo, justamente fotos de políticos.

Figura 37 - Participantes representados: políticos retratados em close.

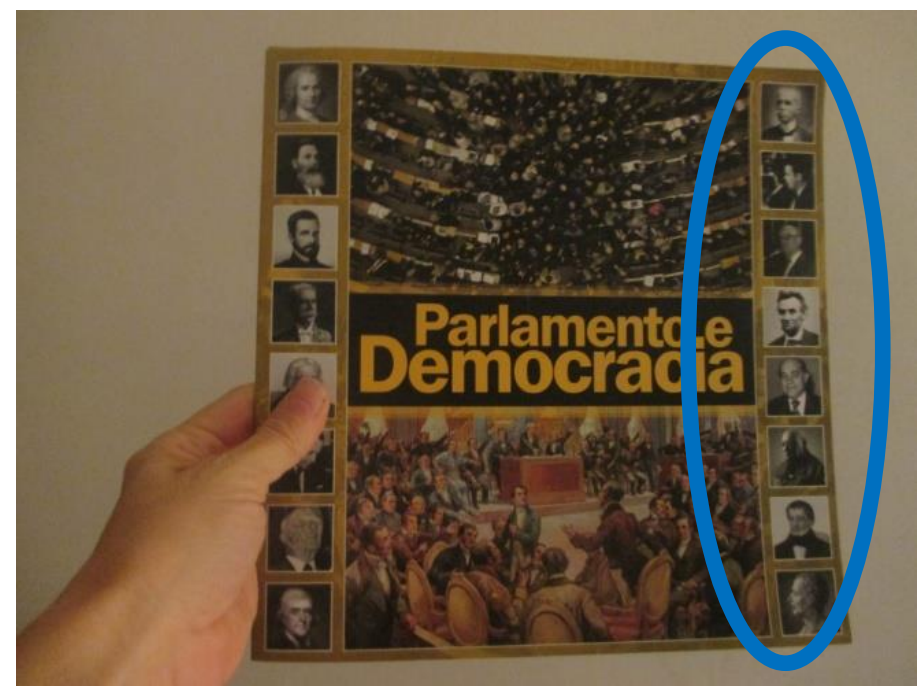

Fonte: Acervo pessoal da autora: foto do prospecto da exposição Parlamento e Democracia 
Os participantes retratados em close na capa (Figura 37) margeiam as imagens maiores superior e inferior, cujos pontos de vista não são coincidentes. A pintura que retrata as Cortes de Lisboa aparece no centro inferior da capa, em contraste com a figura do Parlamento atual, que se posiciona no centro superior da capa, entremeadas pelo cluster central, que enquadra o título da exposição, Parlamento e Democracia. Nesta posição, que potencialmente simboliza o ideal e o desejável, os Parlamentares estão sob o olhar dos viewers, sendo por estes vigiados. São retratados numa posição submissa ao olhar e ao julgamento de uma entidade superior, que poderia ser uma entidade divina. No caso, a perspectiva empodera os viewers, leva-os, como destinatários do folder - ali tratados e tomados como cidadãos, governados, povo brasileiro, sociedade - , a assumirem esta posição celestial, sacrossanta, como guardiães da instituição máxima da democracia, fonte da democracia, em que o Parlamento busca identidade.

Avocando-se o princípio que indica a integração e a complementaridade semântica dos recursos semióticos, podemos asseverar que roboram este intento de aproximação do signmaker/produtor com o viewer/leitor várias passagens dos textos escritos: "Esta Casa também é sua." "Não há democracia forte sem um Legislativo forte, que represente o povo na sua diversidade e plenitude." "Os Parlamentares são mandatários da vontade do povo". "O dia a dia de cada brasileiro passa pelas decisões tomadas no Plenário e nas comissões."

Também a instância midiática (a de fora da governança, não estatal) é cooptada a fazer parte do "nós" - aqueles que querem e valorizam a democracia, e se manifestam em favor desta —, em oposição aos "outros" — os que ameaçam o regime e querem calar o povo e seus representantes: “Ao resgatar a história, a exposição traz o alerta: qualquer regime que cale a voz das ruas, censure a imprensa e enfraqueça o Poder Legislativo merece repúdio.” John B. Thompson (1995) aponta esta fragmentação como um dos modos de operação ideológica, que adota duas estratégias, ambas aplicáveis ao caso: a ênfase nas distinções, pela diferenciação, e a construção de um inimigo, pelo expurgo do outro.

Do significado composicional, as categorias de análise (KRESS; VAN LEEUWEN, 1996) levam em conta realizações relativas a cor, contraste, espaço vazio entre os elementos da composição, linhas de enquadramento, vetores, similaridades. Esses elementos conformam-se nas seguintes categorias: valor da informação, que leva em conta o lugar que ocupam os elementos da composição (direita ou esquerda, margem ou centro, acima ou abaixo); enquadramento, que conecta ou desconecta os elementos representados; saliência, 
que indica que um elemento da composição pode ser melhor captado pelo olhar que outros; e modalidade, que se relaciona ao reality value ou proximidade com o real.

Já discorremos acerca do posicionamento de alguns elementos da composição e a consequente valoração das imagens e textos verbais apresentados, bem assim da evidência ou realce de determinados participantes. Neste ponto, queremos abordar a questão do enquadramento e da sobreposição de imagens, tendo em vista que nestes enxergamos claramente o fenômeno da hibridização dos gêneros e da linguagem, da intertextualidade e da interdiscursividade (FAIRCLOUGH, 2001), pela influência da comunicação mediada por computador, na Era das Mídias (SANTAELLA, 1996) e da cultura digital.

Ao tempo em que os framings separam em clusters as imagens das autoridades que tratam da democracia e do Parlamento (como sói ocorrer nas páginas móveis e manipuláveis da internete), jungem todos os notáveis homens (e mulher) pela autoridade histórica que detêm e por um único anseio: vencer os inimigos comuns, aqueles que desejam silenciar o Parlamento e estabelecer o fim do regime democrático.

\section{Figura 38 - Página interna do folder da exposição Parlamento e Democracia}

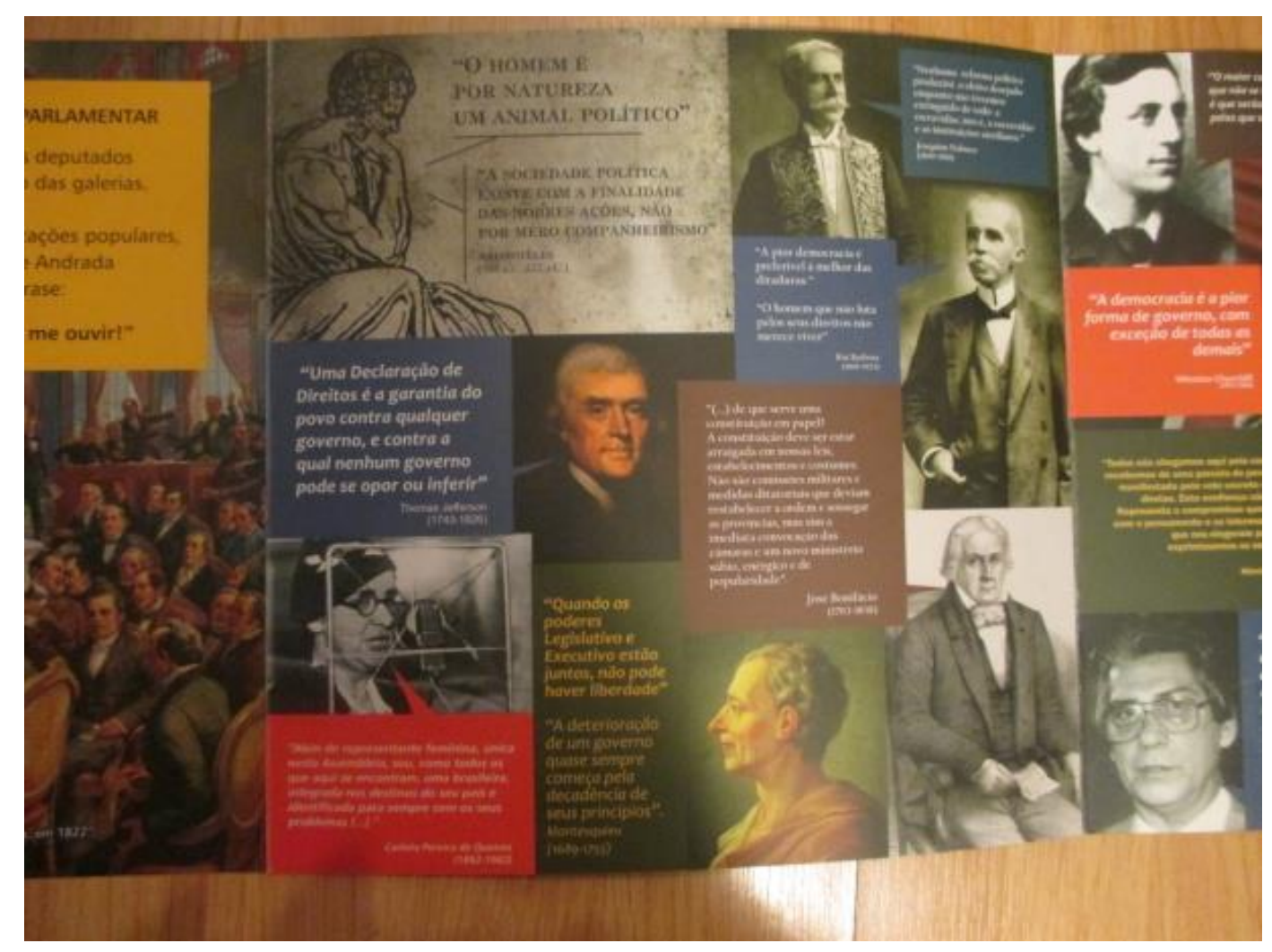

Fonte: Acervo da Câmara dos Deputados. 
Um desses inimigos, representado por meios dos recursos semióticos do modo escrito e imagético, é o regime militar, combatido de forma manifesta e reiterada.

Figura 39 - Os Militares no Poder: foto da exposição Parlamento e Democracia

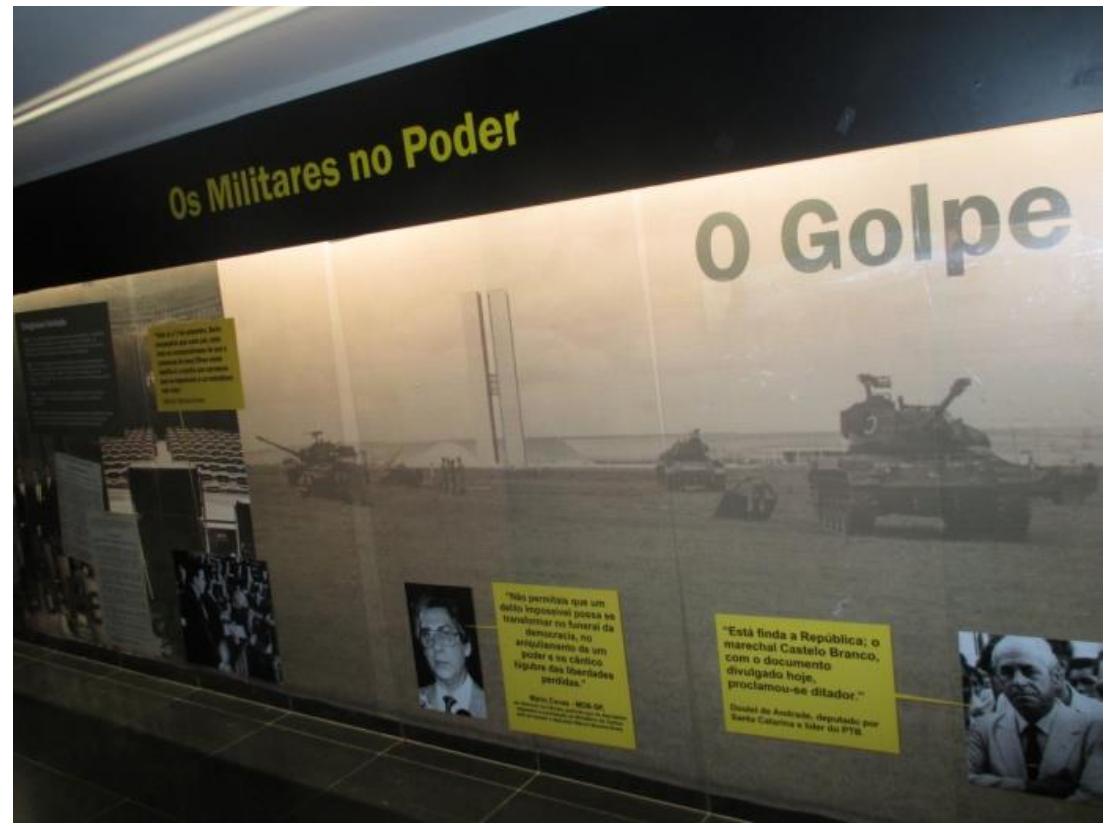

Fonte: Acervo pessoal da autora (fotos da exposição Parlamento e Democracia)

Figura 40 - Plenário vazio: foto da exposição Parlamento e Democracia

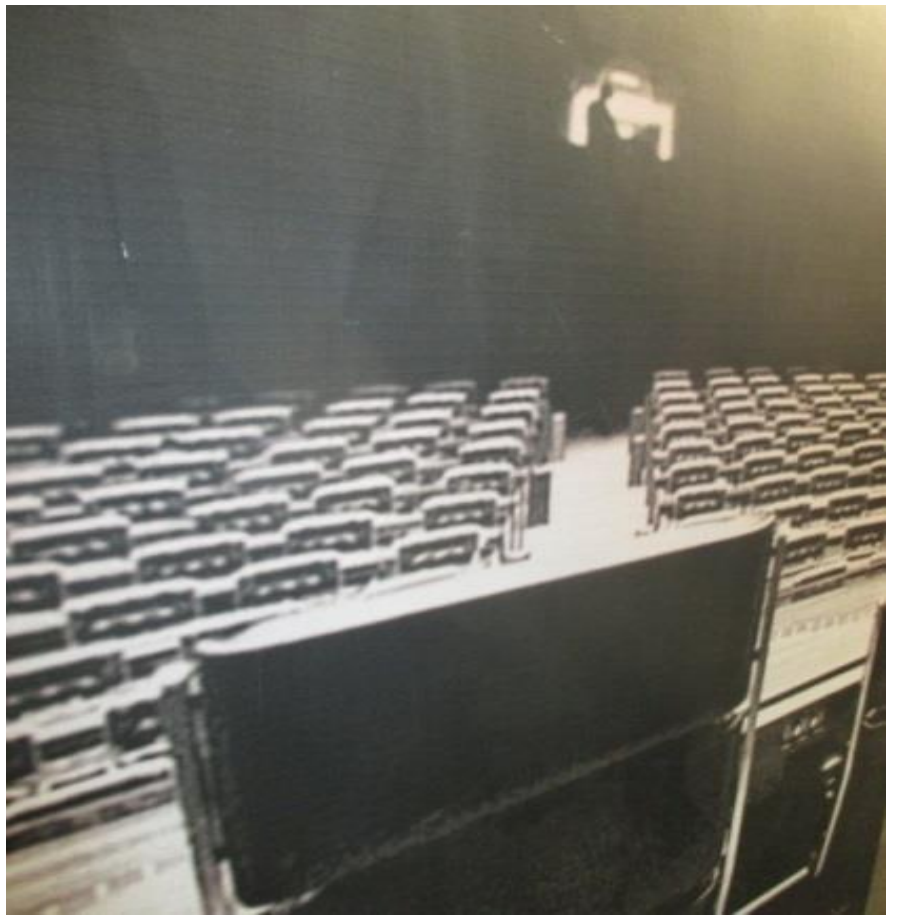

Fonte: Acervo pessoal da autora (fotos da exposição Parlamento e Democracia) 
Permanece inominado, contudo, o outro inimigo do Parlamento e do povo. O texto não o retrata, mas deixa pistas insuspeitas desse opositor. Trata-se do Poder Executivo ou, mais precisamente, do Governo, do partido e do grupo (Partido dos Trabalhadores, suas coligações e a equipe ministerial) que detêm o posto maior, a Presidência da República (então ocupada por Dilma Roussef). Duas hegemonias entram em conflito: a hegemonia legislativa e a hegemonia executiva.

Lê-se, no folder, as frases de Montesquieu (argumentos de autoridade), que denunciam o opositor: "Quando os poderes Legislativo e Executivo estão juntos, não pode haver liberdade" e "A deterioração de um governo quase sempre começa pela decadência de seus princípios". Na primeira oração, a menção aos Poderes se faz em tese, em princípio; recontextualizada, refere-se aos atuais Parlamento e Governo. O mesmo ocorre com o termo "governo”, numa referência implícita à degradação da imagem da Presidente Dilma Roussef, instigada, em grande monta, pelo próprio discurso da oposição. Eis a relação intrínseca entre intertextualidade e recontextualização, apontada por Fairclough (2003, p. 70), cujo resultado é a ressiginificação dos termos, pela relação construída entre o relatado e o original: "A intertextualidade constitui uma questão de recontextualização".

Um pensamento de Pêcheux também trasladado por Fairclough mostra-se fundamental para a nossa análise: "[...] as palavras "mudam de sentido de acordo com as posições de quem as "usa" e também conforme o seu enquadramento em determinada formação discursiva (PÊCHEUX et al, 1979, p. 33).

Retomamos a investigação do inimigo ocultado pela exposição, mas revelado pela análise linguístico-semiótica. Nesse sentido, bastante reveladora, na exposição, é a parte que trata das Atribuições do Congresso Nacional, em posição privilegiada na exposição e salientada pela luz e pelo contraste do preto com o branco. O preto e o branco, juntos, constroem culturalmente um sentido de formalidade, reverência, seriedade, confiabilidadade. 
Figura 41 - Atribuições do Congresso Nacional

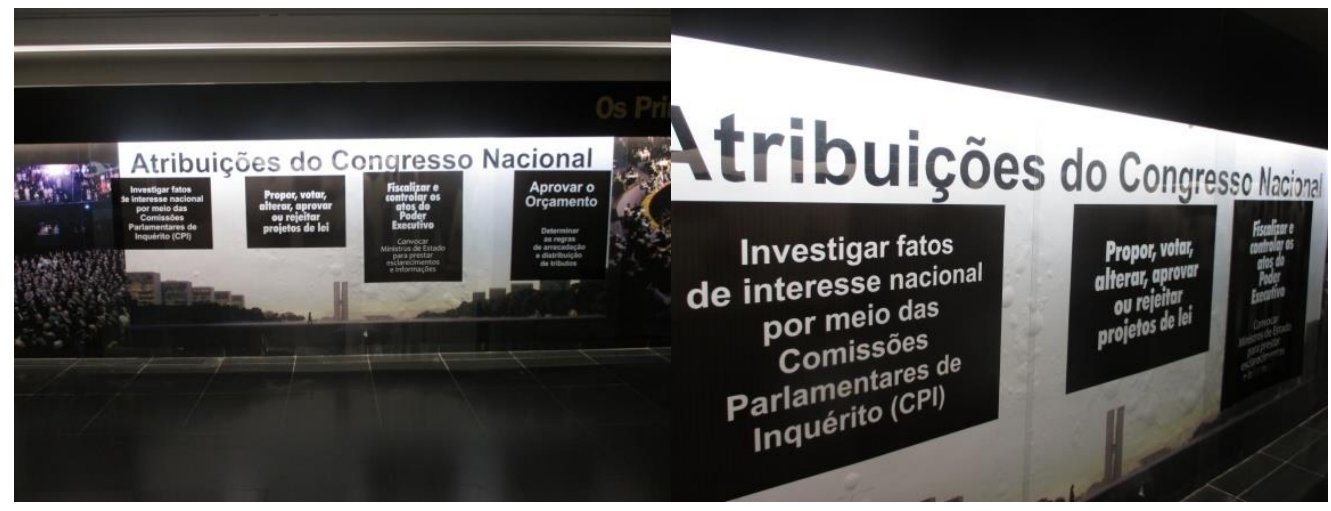

Fonte: Acervo pessoal da autora (foto da exposição Parlamento e Democracia)

Note-se que, ao se apresentarem as atribuições do Congresso Nacional, a primeira transcrita na composição foi justamente esta: "Investigar fatos de interesse nacional por meio de Comissões Parlamentares de Inquérito (CPI)". Ora, não pode ser esta a atribuição priorística do Poder Legislativo e de seus órgãos máximos, Senado da República e Câmara dos Deputados. Ser-lhes-ia fundamental, isto sim, a função legiferente, atribuição que foi listada em segundo lugar: "Propor, votar, alterar, aprovar ou rejeitar projetos de lei". Toda a seleção e composição, tanto do texto na modalidade escrita quanto do textona modalidade imagética, denunciam os propósitos ideológicos dos produtores do texto.

Esta composição, que privilegia a informação topicalizada (a primeira do percurso de leitura, no modo escrito), demonstra o interesse do grupo hegemônico em investigar. Reiterase a formação de campo semântico formado pelas noções de coerção, repressão e repreensão. Trata-se de alerta em relação à importância desta especial atribuição, que foi destacada. Tal investigação poderia ser direcionada ao Poder Executivo. A terceira atribuição o delata: "Fiscalizar e controlar os atos do Poder Executivo. Convocar Ministros de Estado para prestar esclarecimentos e informações". Ao final, menciona-se a última atribuição: "Aprovar o Orçamento. Determinar as regras de arrecadação e distribuição dos recursos."

Tal composição, de per si, já seria bastante expressiva e loquaz, mas há nesse rol de atribuições um agravante, principalmente para uma exposição que se diz histórica e, em segundo plano, constitucional: não há, no numeroso elenco constitucional de "Atribuições do Congresso Nacional" (arts. 48 a 50 da Constituição Federal do Brasil), menção à formação de Comissões Parlamentares de Inquérito. Elas são previstas, sim, no art. 48 da Constituição Federal, na Seção VII, Das Comissões: 
Art. 58. O Congresso Nacional e suas Casas terão comissões permanentes e temporárias, constituídas na forma e com as atribuições previstas no respectivo regimento ou no ato de que resultar sua criação.

$[\ldots]$

$\S 2^{\circ}$ Às comissões, em razão da matéria de sua competência, cabe:

[...]

III - convocar Ministros de Estado para prestar informações sobre assuntos inerentes a suas atribuições;

$\S 3^{\circ}$ As comissões parlamentares de inquérito, que terão poderes de investigação próprios das autoridades judiciais, além de outros previstos nos regimentos das respectivas Casas, serão criadas pela Câmara dos Deputados e pelo Senado Federal, em conjunto ou separadamente, mediante requerimento de um terço de seus membros, para a apuração de fato determinado e por prazo certo, sendo suas conclusões, se for o caso, encaminhadas ao Ministério Público, para que promova a responsabilidade civil ou criminal dos infratores.

O destaque a tais atribuições, entre tantas outras, reforça o caráter de alerta, vigilância, prontidão e sobreaviso, dirigido tanto aos novos Parlamentares, responsáveis por resgatar a face positiva do Parlamento e por esta zelar, quanto ao Poder Executivo, o inimigo identificado nesta análise.

\subsubsection{Análise discursiva crítica e multimodal da parte interna do prospecto}

Dando prosseguimento à análise crítica multimodal, no que se refere aos elementos componentes da organização textual, selecionamos alguns clusters da parte interna do folder, para aprofundar o entendimento do gênero por meio da análise da interdiscursividade e da intertextualidade. Apresentamos o participante representado, a fala que lhe é atribuída, juntamente com a imagem que se lhe apôs, seguida da nossa interpretação e reinterpretação dos significados ali construídos.

O primeiro dos participantes representados analisados é Aristóteles, a imagem e a fala que lhe são atribuídas, trasladados do prospecto da exposição. 
[1] Aristóteles, 384 a.C., 322 a.C.

O homem é por natureza um animal político. A sociedade política existe com a finalidade de nobres ações, não por mero companheirismo.

Figura 42 - Participante representado: Aristóteles

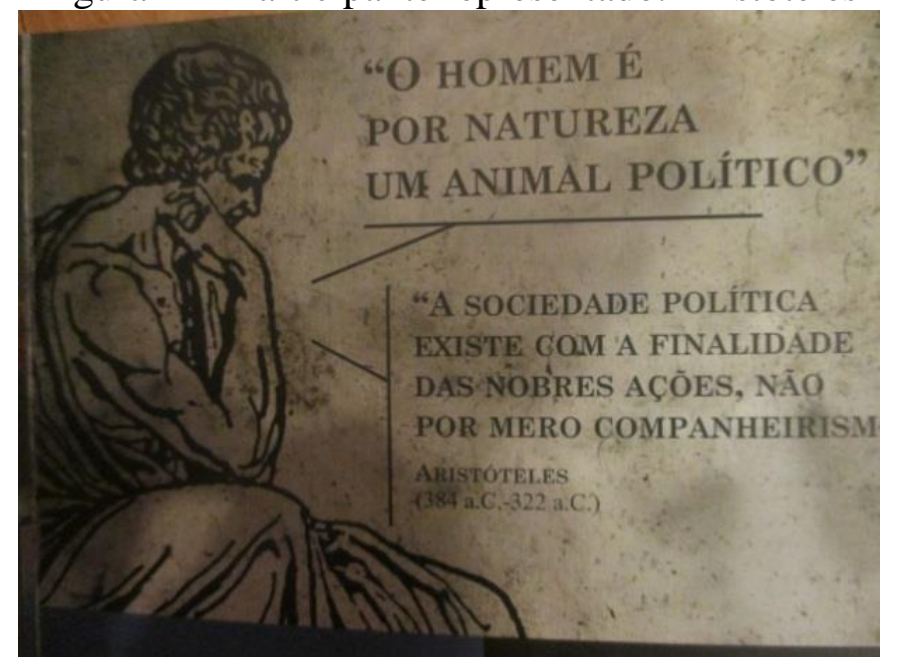

Fonte: Foto do prospecto da exposição Parlamento e Democracia.

Aristóteles, nesta parte do panfleto que destaca e nomeia os notáveis, apresenta-se como a única personalidade não retratada por meio de fotografia ou pintura: ele é representado por um desenho. Note-se que Aristóteles poderia ter sido representado por meio de foto ou desenho de uma das esculturas cuja face lhe é de fato atribuída, conforme figura abaixo. 
Figura 43 - Busto de Aristóteles (cópia romana de uma escultura de Lístios)

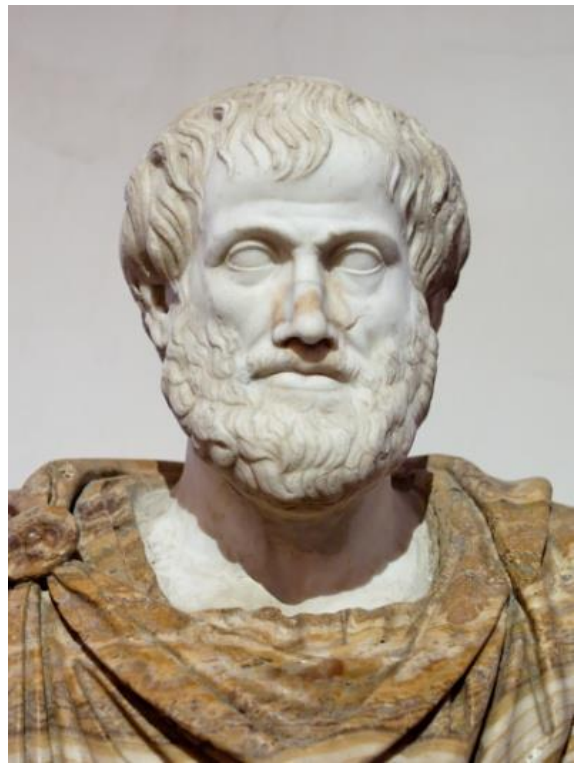

Fonte: Disponível em: <http://biography4u.net/aristotle-photos.html> Acesso em 28 set 2015.

Optou-se, contudo, por desenho que evoca, entre outras, a famosa escultura em bronze de Auguste Rodin, de 1902, conhecida como O Pensador (originalmente chamada O Poeta). Deve-se dizer, a bem da verdade, que a escultura (e, por extensão, o desenho do prospecto), curiosamente, não retrata o filósofo grego Aristóteles. Inicialmente, Rodin intentou representar Dante Alighieri na Porta do Inferno (Divina Comédia), inspirado na obra a Porta do Paraíso, do escultor italiano Lorenzo Ghiberti, tendo mais tarde manifestado sua intenção de homenagear a obra de Michelângelo. Outras estátuas podem ter influenciado Rodin, como a Lorenzo de Medici, de autoria de Michelangelo, a Ugolino e seus filhos, de Carpeaux, ou a Demócrito meditando sobre a morada da alma, de Léon-Alexandre Delhomme.

Abaixo, comparam-se três imagens: a primeira, uma foto da escultura $O$ Pensador, de Auguste Rodin, de 1902; a segunda, uma foto da escultura de bronze Demócrito meditando sobre a morada da alma, de Léon-Alexandre Delhomme, de 1868; a terceira, o desenho reproduzido no folder da exposição Parlamento e Democracia, de autor não nominado e data não assinalada. 
Figura 44 - A intertextualidade no modo visual
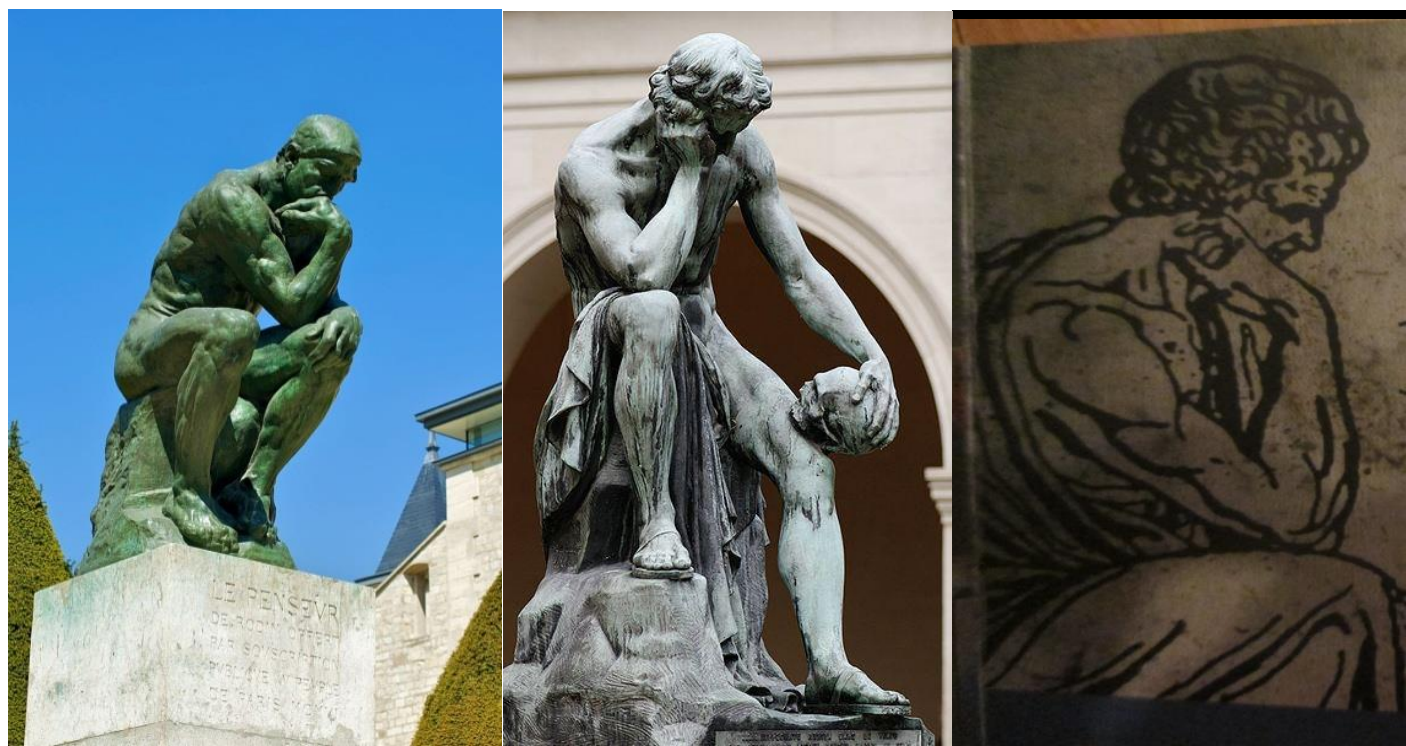

Fontes: Extraídas do Google Imagens, de autoria desconhecida.

Bastante interessante notar como a intertextualidade manifesta-se também nas representações do modo visual. E digno de nota é também a constatação de que estas se integram às representações e estratégias típicas de construção simbólica identificadas na análise dos recursos semióticos do modo escrito, como se vai demonstrando adiante.

O desenho do panfleto, sim, quer retratar Aristóteles, o que se torna inequívoco pela observação das linhas que ligam o desenho às falas atribuídas ao filósofo - para os autores da multimodalidade (KREES; VAN LEEUWEN, 2006, p. 68), os "balões" (no caso, as linhas) fazem a mediação entre o speacher (orador) e o content (fala).

Vale abrir um parêntese para trazer uma observação de Fairclough (2001, p. 137) acerca de heterogeneidades nas relações intertextuais:

Por exemplo, o texto de outro pode estar claramente separado do resto do texto por aspas e o verbo dicendi, ou pode não estar marcado e estar integrado estrutural e estilisticamente, por meio de nova formulação do original, no texto em sua volta.

Tal constatação remete a discussão à análise ao significado composicional do discurso, 
mas também ao significado representacional. O que teria, enfim, levado o produtor do signo a empregar, para o participante representado, imagem que originalmente buscava refletir outra pessoa ou se inspirava em outra personalidade histórica?

A explicação para a escolha do desenho parece desnudar-se pela análise dos recursos semióticos que compõem este cluster. Inicialmente, apoiamo-nos nas próprias palavras de Rodin $^{22}$ para descrever as potencialidades de significado dos recursos semióticos empregados em sua obra:

O que faz meu Pensador pensar é que ele pensa não só com o cérebro, mas também com suas sobrancelhas tensas, suas narinas distendidas e seus lábios comprimidos. Ele pensa com cada músculo de seus braços e pernas, com seus punhos fechados e com seus artelhos curvados.

Com a cabeça baixa, apoiado na mão direita, em posição de instrospecção meditativa profunda, trata-se de uma representação da racionalidade ${ }^{23}$, antes de tudo. Posicionado de forma privilegiada no panfleto, no canto esquerdo superior da página, onde se inicia o vetor da leitura (no Ocidente, de cima para baixo, e da esquerda para a direita), e onde se busca representar (significado representacional) o que já é dado e consensual, e o que está mais próximo do ideal, o texto do discípulo de Platão inaugura a intertextualidade manifesta (neste caso, também constitutiva) de que se compõe toda a parte interna do panfleto.

Tal escolha não é, decerto, aleatória. A anterioridade histórica certamente determina aparição do desenho em primeiro lugar (segue-se uma cronologia), mas há outros fatores que o determinam. Ainda que não seja de conhecimento comum - talvez o seja apenas o fato de que Aristóteles foi um grande filósofo, cujo pensamento serviu de base e origem a muitas das ciências modernas —, não se pode deixar de obervar que o pensador concedia à política o atributo de "ciência mais confiável". Considerando-a essencialmente ligada à moral (doutrina

\footnotetext{
${ }^{22}$ Fonte original não encontrada. Disponível em <http://estacao018.blogspot.com.br/2012/07/de-olho-na-obra-opensador-de-auguste.html $>$ Acesso em 25 set. 2015.

${ }^{23}$ É preciso dizer que se trata de interpretação comum do significado da escultura, aquela resultante do sentido geral, social e historicamente construído, atribuído à obra. Mas é certo que há tantas interpretações quantas forem as subjetividades. Podem-se encontrar, por exemplo, comentários que apontam para o caminho oposto ao da racionalidade, que nesta leitura apontamos como essência da obra: "Talvez hoje, mais de um século passado sobre a obra de Rodin, seja necessário pensar um pouco mais na inutilidade da dimensão física e na escravidão do raciocínio. Talvez o convite deste pensador seja o retorno ao universo imenso e encantador da alma; onde a poesia e a arte preenchem a espírito; onde o sentido da vida se resume ao verdadeiro sentir, ao mundo encantado mas profundamente humano das emoções e dos sentimentos; ao universo infinito onde se encontra a alegria, o amor e a felicidade." Publicado por Lurdinha Batista, em 18 de outubro de 2012, e disponível em: <http://apsicologiaonline.com.br/2012/10/o-pensador-augusto-rodin/>. Acesso em 28 de out de 2015.
} 
moral social), propugnava que o fim último do Estado era a virtude (a formação moral dos cidadãos e os meios necessários para a consecução deste fim). Eis o intento maior da publicidade institucional: a valorização dos Parlamentares e do Parlamento, por meio da aproximação de ambos a atributos relativos à virtude e à moral, no sentido Aristotélico ou não (recontextualização).

Vale observar, ademais, que a escolha do produtor dos signos em relação ao desenho parece remeter a esculturas de mármore típicas de modelos gregos. Assim, indica a ideia de se recorrer estrategicamente à noção de senso comum (FAIRCLOUGH, 2003; KRESS, 1989, p. 20), já que esculturas de mármore remetem à tradição e à cultura grega, e não à personificação de Aristóteles, sendo essa referência suficiente para que o leitor/viewer entenda aquele participante representado como Aristóteles. A constatação do emprego de sentido comum, geral, indica que o sign-maker toma o viewer como cidadão comum, para o qual o sentido construído é bastante e suficiente para o propósito da comunicação instanciada no texto multissemiótico.

A par da intertextualidade, três fenômenos linguísticos revelam-se e sobressaem-se na sentença incorporada "O homem é por natureza um animal político": o primeiro é o sentido obtido pela aplicação do Princípio de Integração dos Recursos Semióticos (KRESS, 1989); o segundo, pelo emprego da estratégia típica de construção simbólica chamada racionalização, um dos modos de legitimação (THOMPSON, 1995); o terceiro, pelo fenômeno da recontextualização (FAIRCLOUGH, 2006).

A estes fenômenos vamo-nos ater mais detalhadamente na análise destas primeiras sentenças [1], para que, adiante, possamos aplicá-las a outras sentenças e sucintamente nos remeter a estas considerações ora formuladas.

Quanto ao Princípio de Integração dos Recursos Semióticos, vale dizer que a representação da racionalidade se apresenta tanto no modo visual quanto no escrito. Se a gravura remete à racionalidade emanada de $O$ Pensador, o texto escrito incorporado ao panfleto também o faz, justamente por meio de estratégia típica de construção simbólica chamada racionalização (Thompson, 1995). Em "O homem é por natureza um animal político" (zoon politikon), a sentença manifesta a intertextualidade constitutiva em relação à definição de homem do próprio Aristóteles, “o ser humano é um animal racional”. Constróise, por meio de relação paradigmática (político/racional), a aproximação dos dois atributos. 
Assim, se a racionalidade é essência do ser humano, também o é a política. E, se a política é parte da natureza do homem, inarredável e inexorável, contra ela não se pode lutar.

A intertextualidade constitutiva floresce no interior de todo o folder. O apelo à racionalidade dirige-se também ao visitante no texto principal do folder, em que se dá as boas-vindas aos visitantes da mostra. Lê-se, ao final: "Entre. Veja. Pesquise. Conheça. Defenda o Parlamento". Por meio de ato ilocucionário diretivo, segundo Mateus (2003, p. 449), o texto "visa obter num futuro imediato a execução de uma determinada ação ou atividade por parte do ouvinte", ou do leitor, no caso.

No que diz respeito à recontextualização, deve-se notar que as palavras "virtude", "moral" e "política" deslocam-se de seu sentido original e histórico (aquele havido trezentos anos antes de Cristo, aproximadamente) para assumirem um sentido atual, sincrônico, comum, geral. E os dois primeiros termos assumem conotações melhorativas ou não pejorativas. Falar em moral e virtude, no sentido comum, implica falar em atributos humanos nobres e coletivamente desejáveis. Fairclough (2003, p. 81), ao tratar de implícitos e suposições, esclarece que "a interpretação que uma pessoa faz de textos, em termos de valores, depende do seu conhecimento e reconhecimento do sistema de valores morais".

Esta noção de "sentido comum" compatibiliza-se com o que Fairclough (Ibid., p. 77) chama de "campo comum", ou seja, "sentidos que são compartilhados e podem ser tomados como dados". A importância deste conceito revela-se crucial para o autor, pois, segundo Fairclough, nenhuma forma de comunicação ou interação social pode ser concebida sem os campos comuns.

Por seu turno, a palavra "política” originalmente se reportava à polis grega. Assim, a natureza do zoon politikon (animal político) de Aristóteles ensejava uma necessária interação do homem na cidade-Estado (polis). Relexicalizada no texto incorporado, a palavra remete às práticas políticas hodiernas e a seus protagonistas, os políticos — virtuosos e moralmente escorreitos.

Finalmente, na sentença "A sociedade política existe com a finalidade de nobres ações, não por mero companheirismo" - que se interliga interdiscursivamente com a primeira sentença —, identifica-se uma suposição existencial (a respeito do que existe no mundo real), conformada por meio do emprego do artigo definido "a" (FAIRCLOUGH, 2003, 
p. 82). Pressupõe-se a existência de uma sociedade política, uma unidade de homens nobres, irmanados em torno de uma finalidade nobre - e não um aglomerado não coevo de partidos sem identidade ideológica definida, e não personalidades políticas que tomam a política como uma prática de engendrar fórmulas para se manter no poder a qualquer custo.

Thompson (1995) apontaria para o intento de despertar valoração positiva, por meio da estratégia típica de construção simbólica denominada eufemização, que confere aos políticos qualidades fascinantes. Entende-se, nesta análise, que se recorre a espécie de romantização ou mitificação da política e dos seus praticantes, retratados como nobres heróis, capazes de "nobres ações". A transposição de sentidos do agente para a ação, por meio de hipálage - figura por meio da qual se atribui a determinado palavra ou expressão de uma frase o que convém logicamente a outra da mesma frase, explícita ou subentendida - , , consiste numa interessante estratégia de valorização indireta da face positiva do agente (CHARAUDEAU, 2006, p. 42).

Nesse sentido, exsurgem indícios também do modo de operação da ideologia denominado dissimulação, por meio de dois estratagemas: a omissão dos fatos, ou desprezo a notícias desairosas em relação aos políticos que os atrela a atos de corrupção; o ocultamento das relações de dominação, por meio do deslocamento: não se diz claramente que a sociedade política é nobre, mas que nobres são as suas ações.

Fairclough (2003, p. 77) trata do tema em termos de seletividade, ao aduzir que a "intertextualidade é inevitavelmente seletiva em relação ao que está incluído e ao que está excluído dos eventos e textos representados". 


\section{[2] Montesquieu, 1689-1755}

Quando os poderes Legislativo e Executivo estão juntos, não pode haver liberdade. A deterioração de um governo quase sempre começa pela decadência de seus princípios.

Figura 45 - Participante representado: Montesquieu

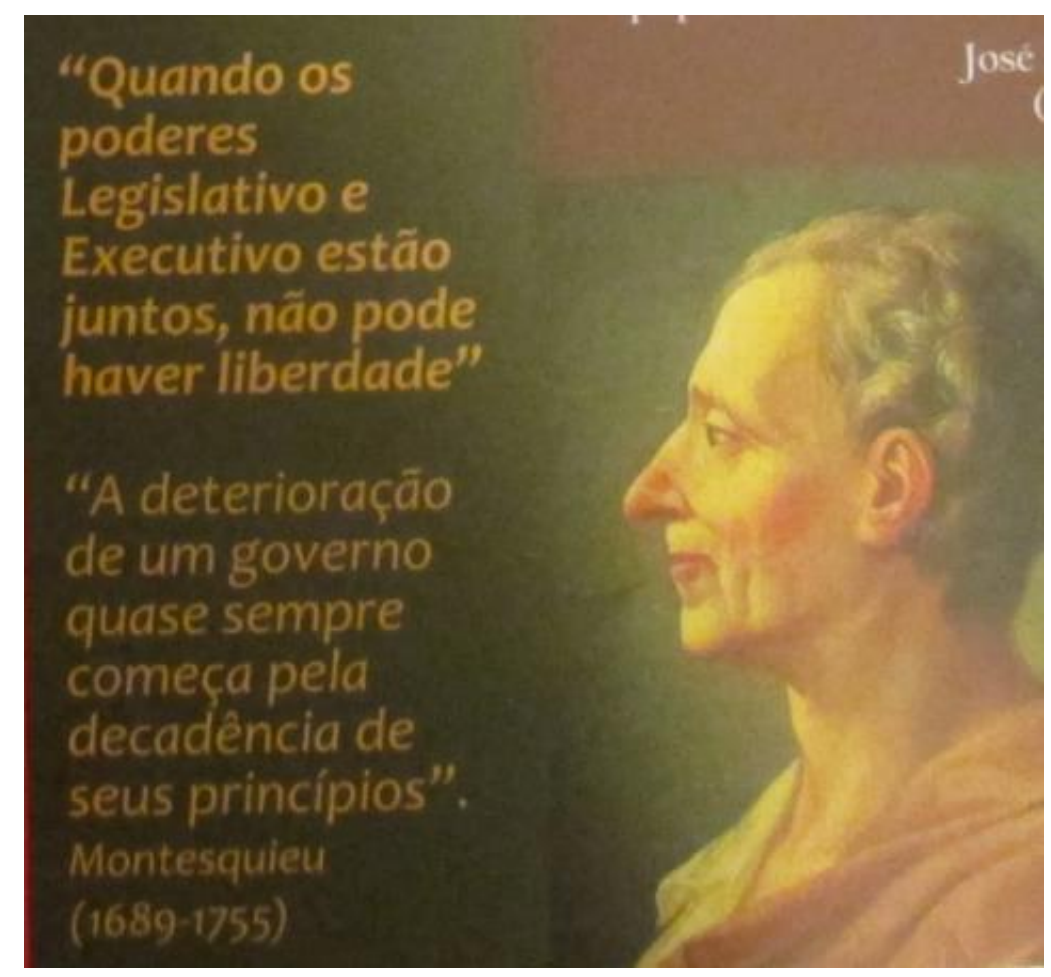

Fonte: Foto de detalhe do prospecto da exposição Parlamento e Democracia

Com o lema "Câmara independente, Democracia forte", a campanha do Deputado Eduardo Cunha à Presidência da Câmara dos Deputados já sinalizava o intento de distanciamento do Poder Legislativo em relação ao Poder Executivo e ao Governo, capitaneado pela então Presidenta reeleita Dilma Rousseff. A campanha, vitoriosa, fez incorporar o nome do Deputado à logomarca da Câmara dos Deputados e as cores que simbolizam o Brasil, construindo um poderoso significado representacional (KRESS, 1996) e, simultaneamente, acionando o significado identificacional (FAIRCLOUGH, 2003), no intuito — exitoso — de fundirem-se as identidades individual, institucional e nacional.

Eleito, em seu discurso de posse Cunha ratificou o bordão da campanha:

A única coisa é a busca da altivez e da independência do Parlamento [...] uma independência que não pode ser submissa a qualquer Poder, seja o Executivo, seja o Judiciário. [.... $]^{24}$

\footnotetext{
${ }^{24}$ Fonte: Anais da Câmara dos Deputados.
} 
Figura 46 - Campanha de Eduardo Cunha à Presidência da Câmara dos Deputados, 2014.

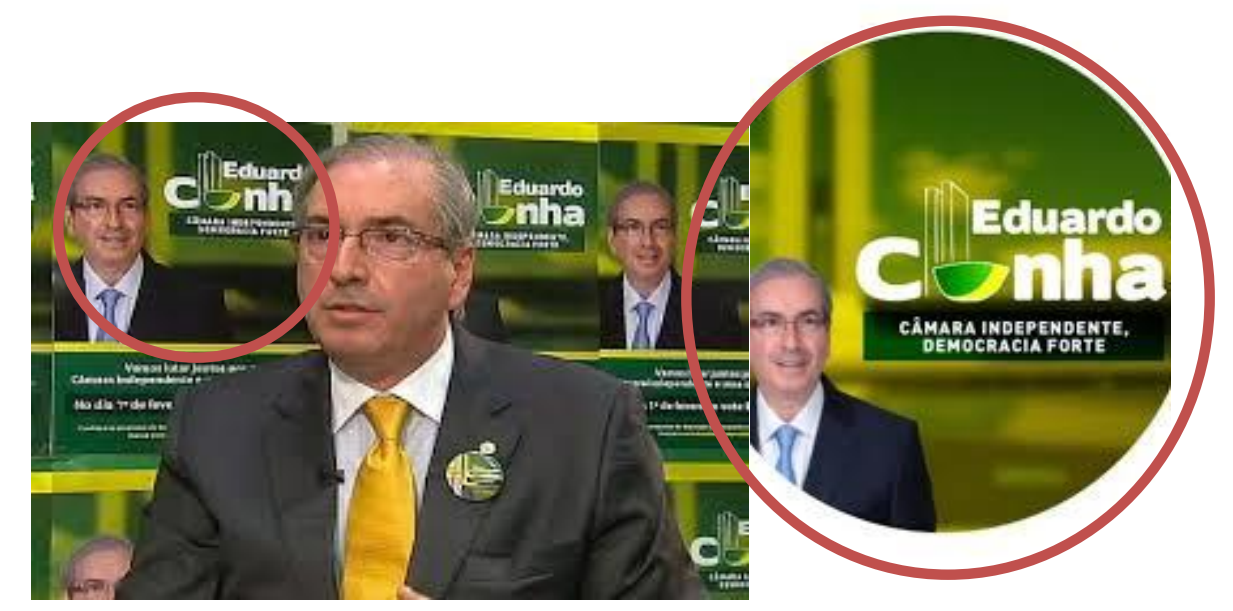

Fonte: Disponível no acervo do site da Câmara dos Deputados.

É de ressaltar que a prevenção em relação também ao Judiciário já se faz pressentir no discurso de posse de Eduardo Cunha, e se explicita num momento posterior, meses depois, quando o Presidente da Câmara declara o seu rompimento com o Poder Executivo e ataca com ferocidade o Poder Judiciário, que publiciza a investigação contra o Deputado, já no segundo semestre de 2015.

Vale dizer que a dissimulação, como modo de operação da ideologia, remanesce recorrente no discurso político em geral. Para Patrick Charadeau (2006), "o discurso político é, por excelência, o lugar de um jogo de máscaras". Foucault, no mesmo sentido, defende: "O poder é tolerável somente na condição de que mascare uma grande parte de si mesmo. Seu sucesso é proporcional à sua habilidade para esconder seus próprios mecanismos". Em oposição política dissimulada ao Poder Executivo - dissimulada porque, oficialmente, o partido do Presidente eleito da Câmara dos Deputados (PMDB) então compunha a base de apoio da Presidenta da República, reeleita, tendo inclusive aquele partido a detença do cargo de Vice-Presidente da República -, os textos da exposição e do folder apresentam-se ricos em vestígios e marcas textuais e discursivos que apontam o Governo como adversário.

Retoma-se, neste ponto, a análise das sentenças de Montesquieu, das quais se apropriou a exposição. Em $O$ Espírito das Leis, redigido na primeira metade do séc. XVIII, na antevéspera da Revolução Francesa (1789), com manifestas intenções antiabsolutistas, em 
questionamento às origens da Monarquia, Montesquieu disserta sobre a virtude política e a importância de uma constituição que evite o despotismo, elabora a teoria da liberdade política, assegurada por uma certa divisão de poderes — "só o poder freia o poder" - e defende (MONTESQUIEU, 1748 apud CHEVALLIER, 2001, p. 124) que "deve ser de moderação o espírito do legislador; o bem político, como o bem moral, sempre se acha entre os dois limites.” Novamente, trazem-se à colação questões morais ligadas à atividade política, o que a segunda sentença incorporada consolida: "A decadência de um governo sempre começa pela decadência de seus princípios."

Ademais, o filósofo postula que o legislador obedece a princípios, a motivos, a tendências e diretrizes examináveis pela razão. Reiteramente, em todo o folder, em intertextualidade constitutiva, a racionalidade atrela os argumentos retóricos, como estratégia discursiva recorrente, constante.

Surpreendente descobrir em Montesquieu (MONTESQUIEU, 1748 apud CHEVALLIER, 2001, p. 121, itálico no original) centelhas do que, dois séculos mais tarde, verifica-se no dialogismo Bakhtiniano:

Estabeleci os princípios e vi os casos particulares inclinarem-se-lhes como que por si mesmos, as histórias de todas as nações serem apenas suas consequências, cada lei particular ligar-se a outras ou depender de outra mais geral. Quais são esses princípios? Ei-los: toda lei tem sua razão, porque toda lei é relativa a um elemento da realidade física, moral ou social; toda lei supõe uma relação. Um encadeamento de relações, uma organização de relações, um sistema de relações (positivas), eis o espírito das leis.

O que se há de sublinhar, nas constatações analíticas até este ponto? Antes de tudo, o fato de se ter escolhido, na exposição de arte, um inimigo do Parlamento e do povo: o Governo (Executivo). Torna-se bastante conveniente para o segmento que ocupa a Presidência da Câmara dos Deputados fazê-lo, pois conta com um aliado involuntário: toda a mídia comercial, que se volta às denúncias de corrupção relacionadas à Petrobrás e à operação levada a cabo pelo Ministério Público e o Poder Judiciário, a chamada Operação Lava-Jato.

Outros intertextos possibilitam esta interpretação — que textualmente orientada, focaliza as marcas linguístico-discursivas - a qual aponta o Poder Executivo como inimigo oculto do segmento político que assomou à Presidência da Câmara dos Deputados na 55a Legislatura, no início de 2015. Verbi gratia, imagens da exposição apresentam o termo impeachment e a expressão "Impeachment já" (cada qual com sua fonte, cor e 
enquadramento) sobrepostas à imagem de jovens entusiasmados, felizes, em êxtase, os "caraspintadas", como ficaram conhecidos os manifestantes, em verde e amarelo, quando do impeachment do ex-Presidente do Brasil Fernando Collor de Mello.

O atrelamento de fato indesejável, desairoso para a comunidade política nacional e para a sociedade em geral, o impeachment de um Presidente da República por crime de responsabilidade, a imagens festivas destaca-se no final da narrativa cronológica histórica como uma peroração, um epílogo, um desfecho triunfal de uma estória de heróis, cujo título bem poderia ser este: “A vitória da democracia contra o inimigo do povo”. E leia-se, em “inimigo do povo", o Poder Executivo ou o Governo.

Figura 47 - Foto de fechamento da exposição Parlamento e Democracia

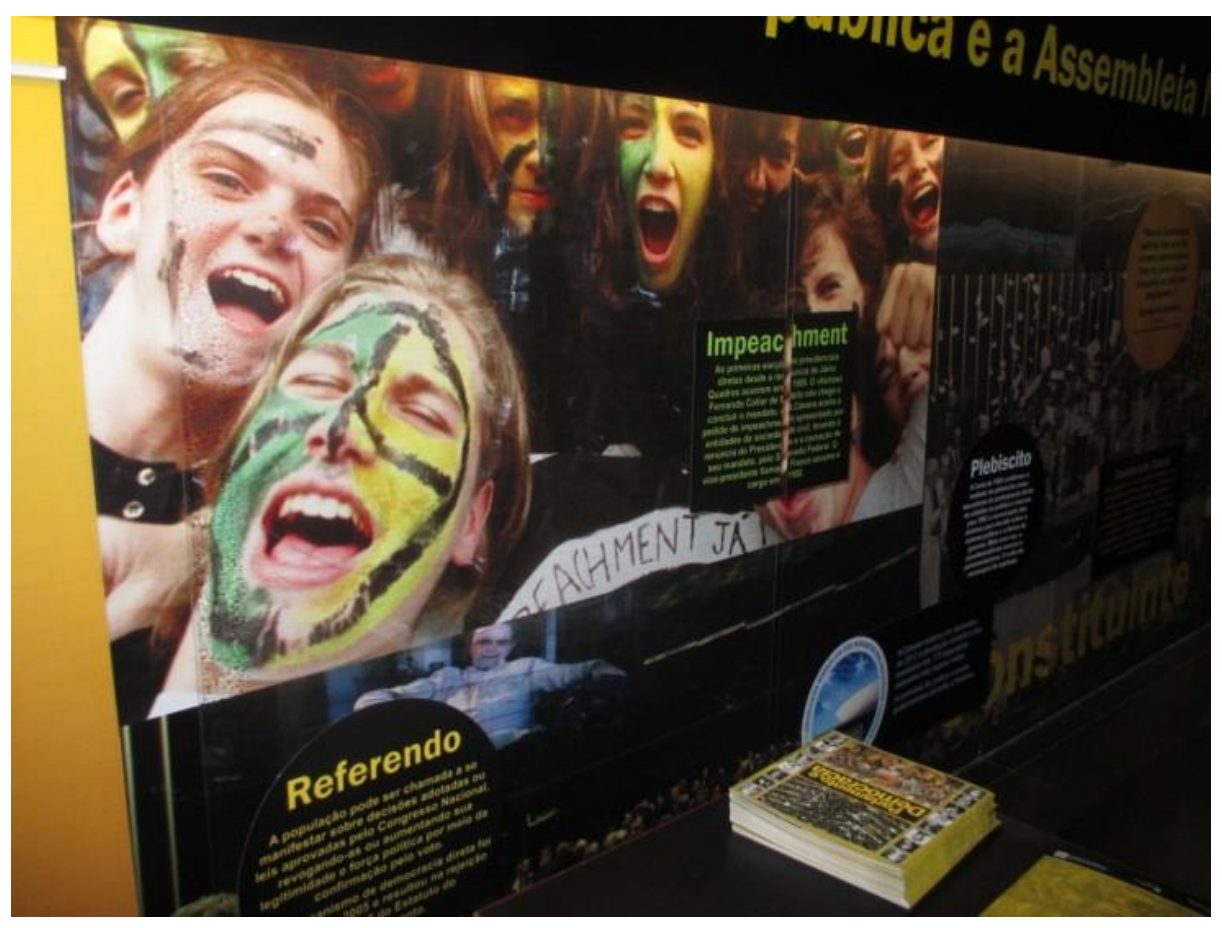

Fonte: Acervo pessoal da autora.

Fairclough (2003, p. 74) disserta sobre o enquadramento (contextualização em relação às outras partes do texto) e a ordenação do texto, e chama atenção para esta saliente (privilegiada) posição que chama de "arremate", ou seja, a parte final do relato. E assim se encerra, com um sugestivo e sugestionador relato, a história contada da democracia brasileira.

Não é demasiado lembrar que, segundo o art. 80 da Constituição brasileira, o segundo na linha sucessória, caso o Presidente e o Vice-Presidente da República sejam ambos impedidos de exercer a função de Chefe de Estado, é o Presidente da Câmara dos Deputados. 
Art. 80. Em caso de impedimento do Presidente e do Vice-Presidente, ou vacância dos respectivos cargos, serão sucessivamente chamados ao exercício da Presidência o Presidente da Câmara dos Deputados, o do Senado Federal e o do Supremo Tribunal Federal.

Em outra imagem, bastante expressiva, Getúlio Vargas, mencionado na exposição como "ditador", aparece com as mãos sujas de petróleo. A primeira imagem, abaixo, mostra o texto que adjetiva Getúlio Vargas como ditador. As próximas imagens, na página seguinte, mostram-no com as mãos sujas de petróleo.

Figura 48 - Contexto da Constituição de 1946 (texto da exposição Parlamento e Democracia)

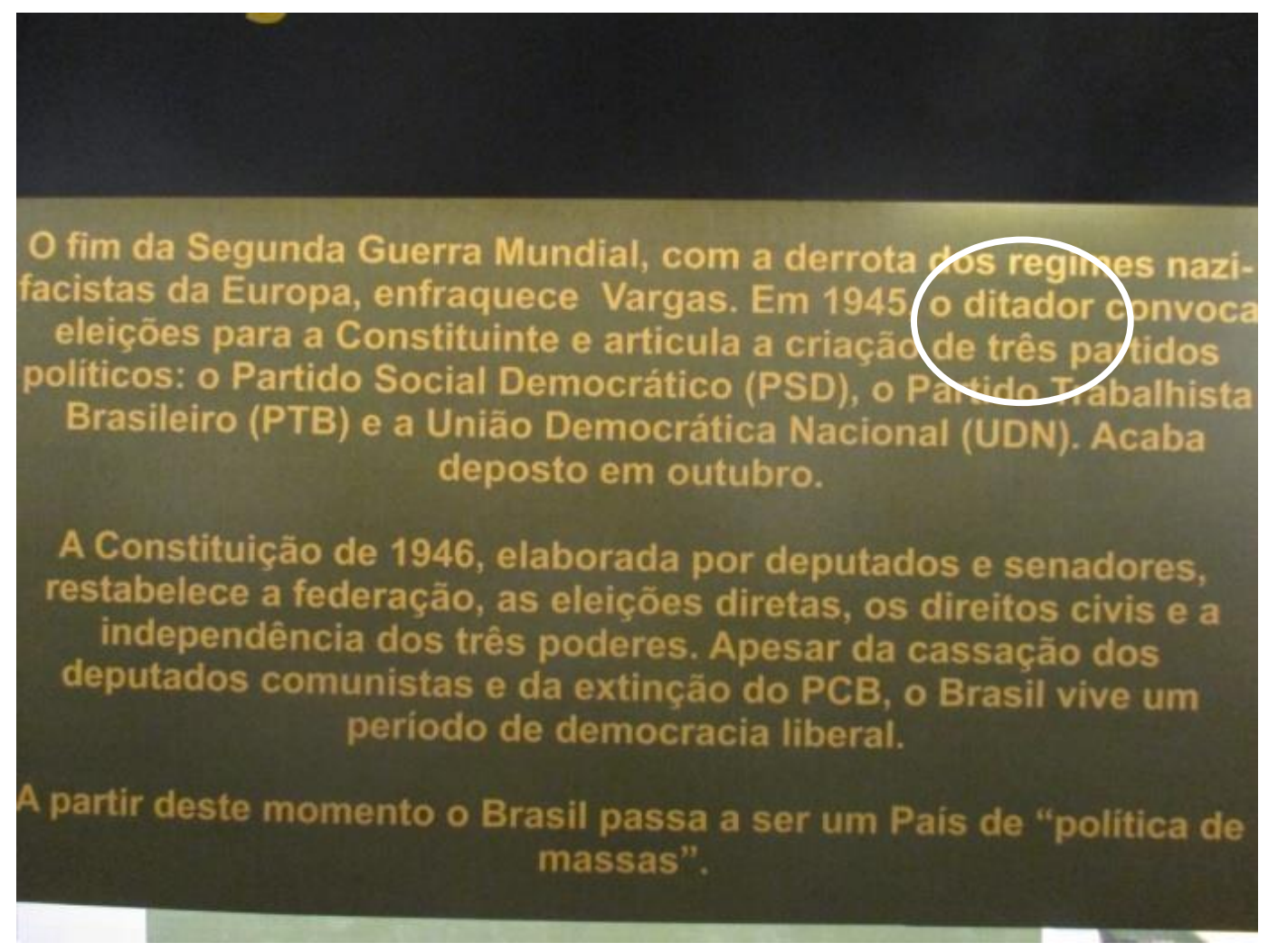

Fonte: Acervo pessoal da autora (foto da exposição Parlamento e Democracia). 
Figura 49 - Fotos de Getúlio Vargas com as mãos sujas de petróleo

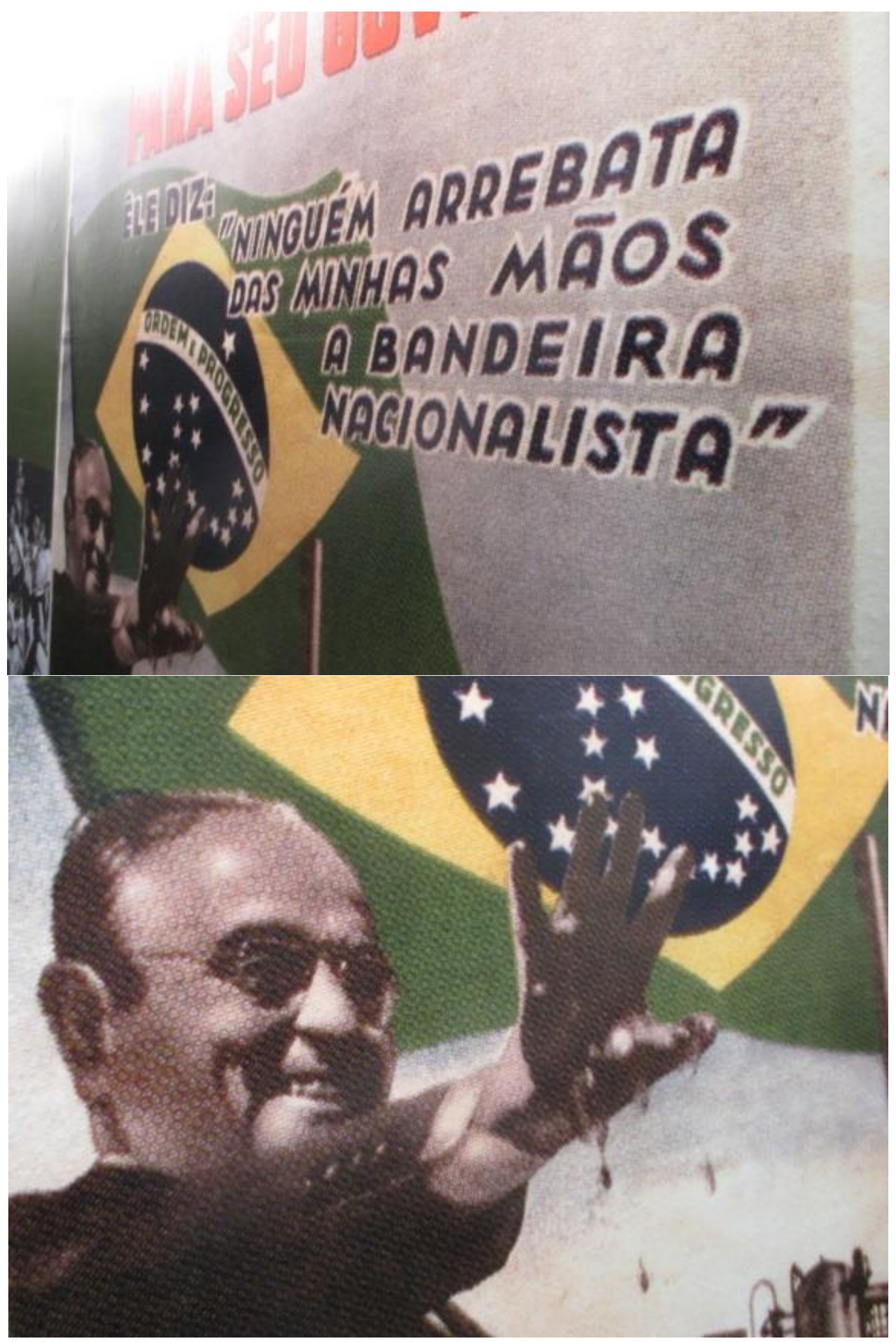

Fonte: Acervo pessoal da autora (foto da exposição Parlamento e Democracia) 
A mesma foto, contextualizada e recontextualizada em diferentes cronotopos (Bakhtin, 1929), pôde servir a pelo menos três propósitos discursivos. Em sua publicação original, a foto se prestou à campanha nacionalista e desenvolvimentista de Getúlio Vargas em 1936, tendo sido empregada pelo produtor do texto de modo a exaltar as qualidades do então Presidente, como homem que "põe a mão na massa" e que carrega em suas próprias mãos a independência e o futuro do País, simbolizados pelo petróleo.

A imagem de Getúlio Vargas na frente da bandeira do Brasil, com as mãos sujas de petróleo, sorrindo, junge-se ao texto escrito, uma fala atribuída ao marcante e polêmico exPresidente do Brasil: "Ninguém arrebata das minhas mãos a bandeira nacionalista." A bandeira nacionalista simboliza a unificação, outro modo geral de operação da ideologia, segundo Thompson (2005). Por meio da estratégia de simbolização da unidade, o intento é a construção da identidade ou identificação instituição/coletividade. Para uma dimensão mais ampla, a da ideologia, Fairclough (2003, p. 82) complementa: “A busca por hegemonia é uma questão de buscar universalizar sentidos particulares".

Esta mesma imagem já foi utilizada por outros políticos, com o mesmo propósito de promoção política. Note-se, por meio da intertextualidade imagética, como se a empregou o então Presidente do Brasil, Luís Inácio Lula da Silva.

Figura 50 - Lula com as mãos sujas de petróleo.

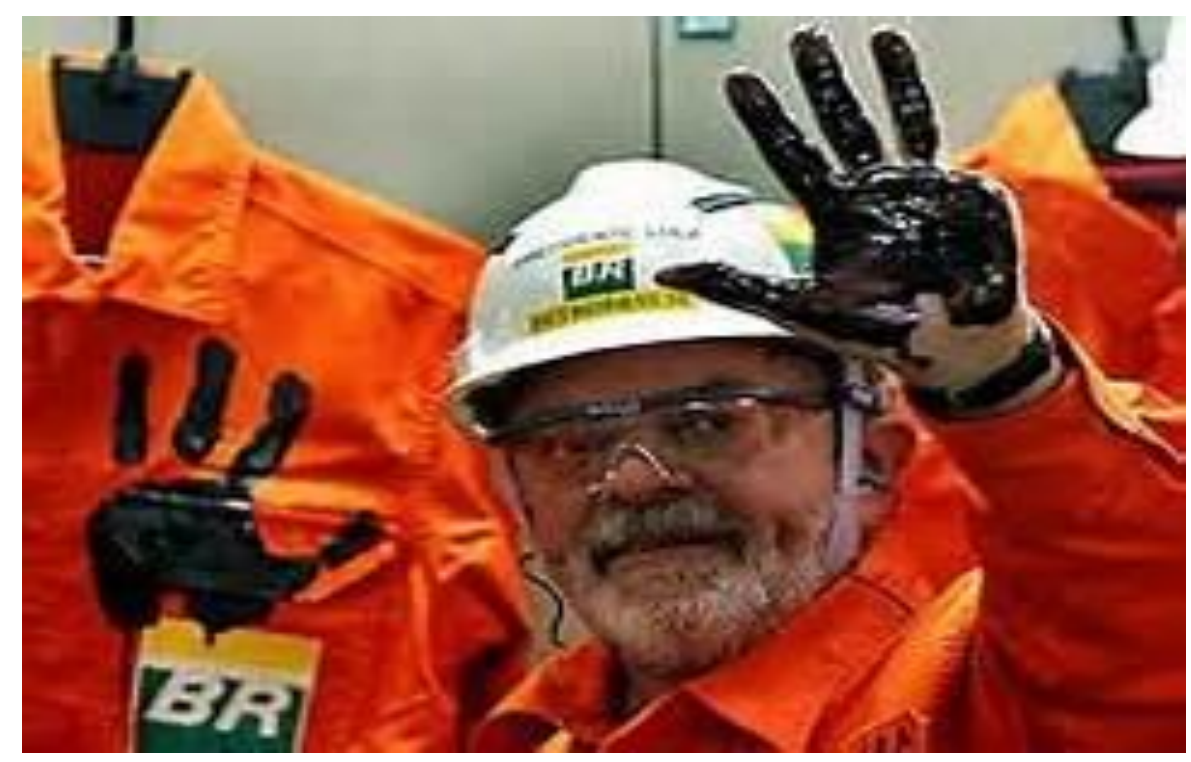

Fonte: Foto de Ricardo Setti, publicada pela revista Veja. ${ }^{25}$

\footnotetext{
${ }^{25}$ Disponível em: <http://veja.abril.com.br/blog/ricardo-setti/files/2014/03/Lula-petrobras-ag\%C3\%AAncia-
} 
Entretanto, a mesma imagem, num segundo cronotopos, apresentando-se como participante representado na exposição Parlamento e Democracia a figura de Getúlio, na foto, faz parte do processo narrativo histórico global, que diz pretender contar a história da democracia no País, servindo precipuamente a este propósito de registro histórico.

Num terceiro momento, contudo, recontextualizada (mas no mesmo cronotopos), o significado somente se constrói se se considerar o texto e o participante representado neste texto sob o viés da interdiscursividade: o texto relaciona-se inexoravelmente ao contexto situacional para construir um significado global, que se completa em outra dimensão que não somente a textual (no sentido linguístico). Dessa forma, conforma-se metáfora visual (cf. VIEIRA, 2010, p. 51), em que o sentido das "mãos sujas" pelo petróleo já não mais é melhorativo, e sim pejorativo e atrelado à corrupçao e ao desvio de recursos da estatal Petrobrás no contexto temporal da $55^{\text {a }}$ Legislatura, quando se produzem e expõem os textos da mostra cultural.

Poder-se-ia indagar, num esforço interpretativo amplo, que se estaria arquitetando crítica velada - portanto, mais eficaz - à então Chefe do Executivo, uma ditadora (deslocamento) que estaria com as mãos sujas pela corrução e, por isso, sujeita a possível (até então, somente aventado, mas já projetado) processo de impeachment? Entendemos que não seria esta uma interpretação descartável.

Nesse sentido, Fairclough (2003, p. 165) cita Graham (2001) e aponta característica geral dos textos políticos atuais, que consiste em apresentar como fato o que é apenas predição ou valor: "Graham (2001a) sugere que os dois aspectos das "mensagens de promoção [...] o deslizamento entre fato e valor, e entre fato e predição, são aspectos gerais dos textos contemporâneos". Essa projeção do impeachment exemplifica bem a finalidade política que motivou a construção do texto. Poder-se-ia entender esse processo de construção semiótica como derivado de um fenômeno social que Wernick (1991) define como "cultura da promoção", que seria uma "gama de fenômenos culturais" transformadores do mundo simbólico produzido, o qual teria como uma de suas funções, invariavelmente e coextensivamente, comunicar uma mensagem promocional (informar e promover). Qualquer que seja o referente, a mensagem promocional representa (move-se em lugar de), advoga 
(move-se em parte de) e antecipa (move-se em direção a).

Ainda em relação ao texto multimodal em epígrafe, na menção ao slogan "O petróleo é nosso", transparece clara referência a um dos slogans de campanha de reeleição da Presidenta Dilma Roussef, "O pré-sal é nosso", campanha que reedita aquela de 1936. A intertextualidade, neste caso, é discursiva e reforça a personificação do Executivo como inimigo, pois que o texto se aproveita do fato de o Governo estar vulnerável, sob investigação, devido aos "escândalos" de desvios de recursos da Petrobrás, considerada patrimônio nacional.

Figura 51 - Campanha eleitoral (2014) de Dilma Rousseff, com ênfase no pré-sal.

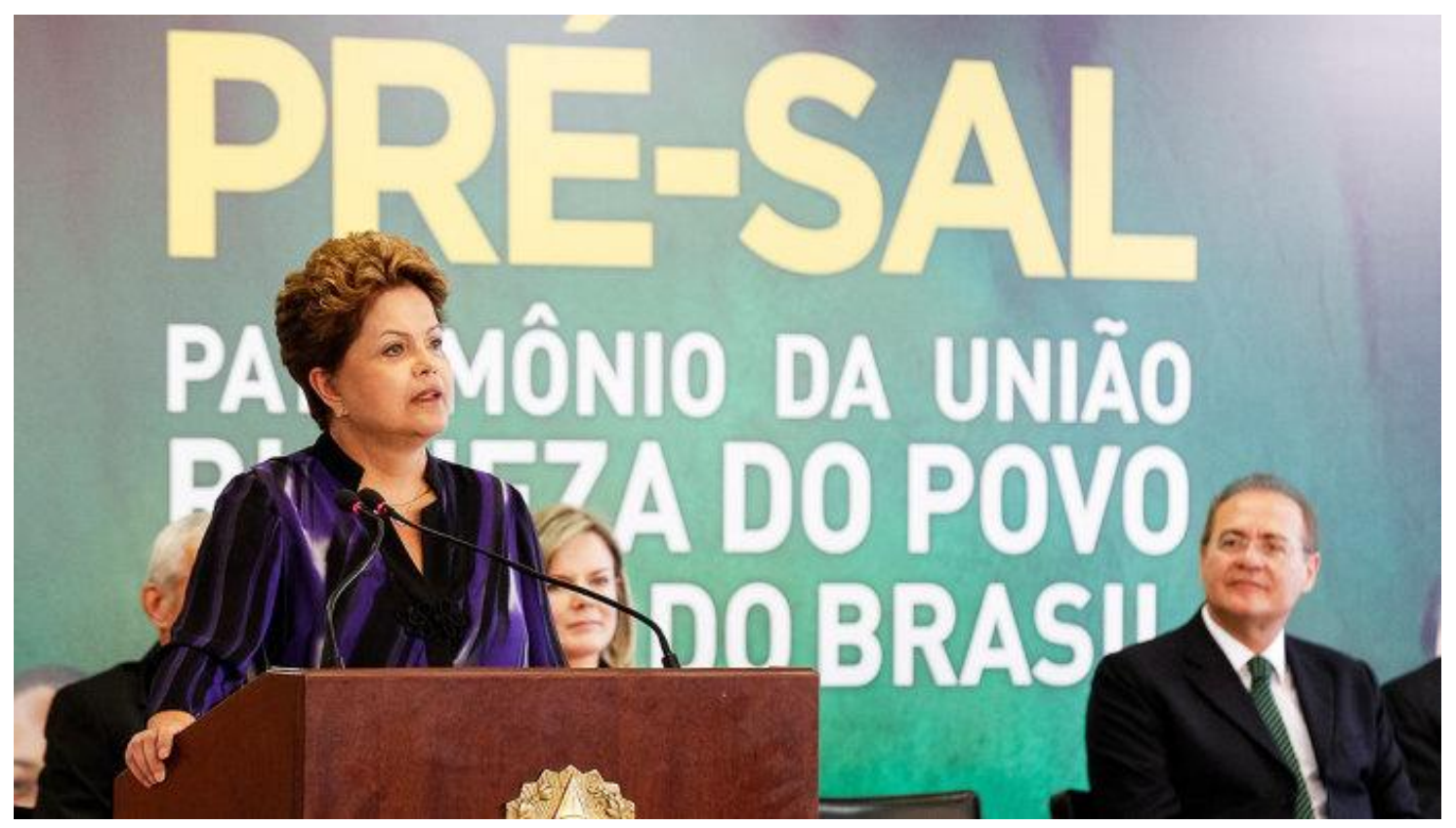

Fonte: Foto de Roberto Stuckert Filho/PR, para a revista Veja. ${ }^{26}$

Note-se o destaque, na exposição histórica (Figura 52), dado à manchete de capa de revista que diz: "Petrobrás, o outro negro que dará a independência do Brasil". Em metáfora gramatical (relação paradigmática de Petrobrás/petróleo/ouro negro), deposita-se na empresa estatal toda a esperança de independência do País, pela riqueza de "ouro" (tal como no período colonial) desta Nação. Se menos, na exposição Parlamento e Democracia, reforça-se a importância da Petrobrás para o desenvolvimento nacional, ao mesmo tempo em que deixa implícita a mensagem: é esse o "ouro" que está sendo espoliado pelo Governo de agora, consoante denúncias massivas da mídia.

\footnotetext{
${ }^{26}$ Disponível em: < http://veja.abril.com.br/noticia/economia/petrobras-vai-colocar-blocos-de-pre-sal-a-venda/> Acesso em: 22 out. 2015.
} 
Figura 52 - O outro negro que dará a independência do Brasil (foto da exposição)

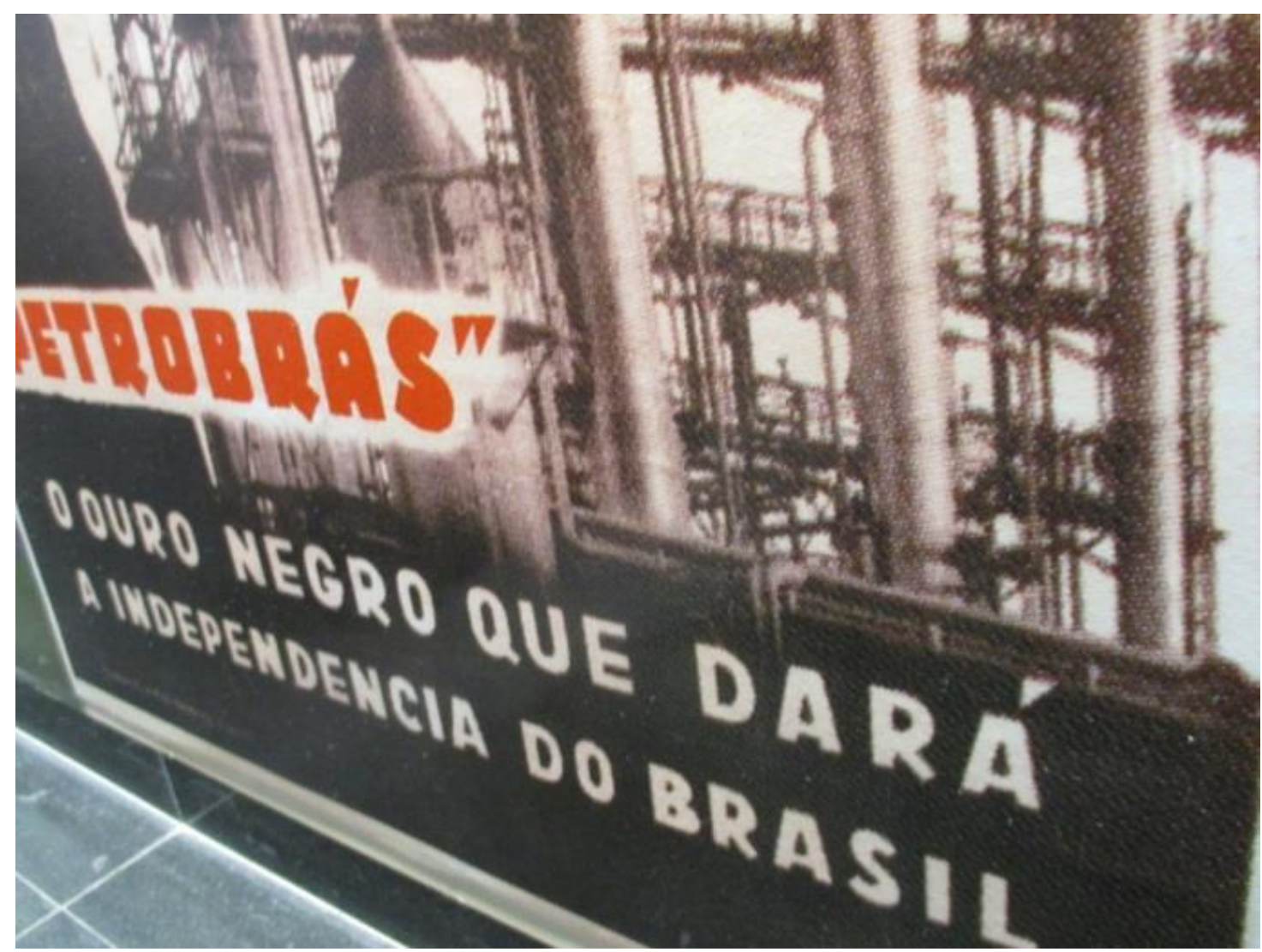

Fonte: Acervo pessoal da autora (foto da exposição Parlamento e Democracia)

Na dimensão do significado identificacional, o próprio título da exposição, Parlamento e Democracia, antecipa o esforço (por meio dos textos incorporados) de construir ou reconstruir semanticamente a conexão entre o Parlamento (representante) e o cidadão (representado), reconciliando-os. Soberano nesta análise que ora se edifica, o Princípio de Integração dos Recursos Semióticos remanesce imprescindível para o esforço e o sucesso interpretativo. Conjuga, neste desiderato, todos os recursos semióticos empregados: os textos escritos e os não escritos, as imagens estampadas e as omitidas.

O texto a seguir trasladado do jornal "A Verdade", de janeiro de 2012, buscou construir, em termos semióticos, o argumento em prol do papel importante do produtor dos signos, a Câmara dos Deputados do Brasil, na questão do petróleo: "Mas a Câmara ouviu as vozes do povo e até forças políticas contrárias ao monopólio estatal se calaram ante o clamor e a vontade das massas, mobilizadas em todo o país, sob o lema imorredouro O Petróleo é Nosso." 
Figura 53 - O papel da Câmara dos Deputados na campanha "O Petróleo é Nosso".

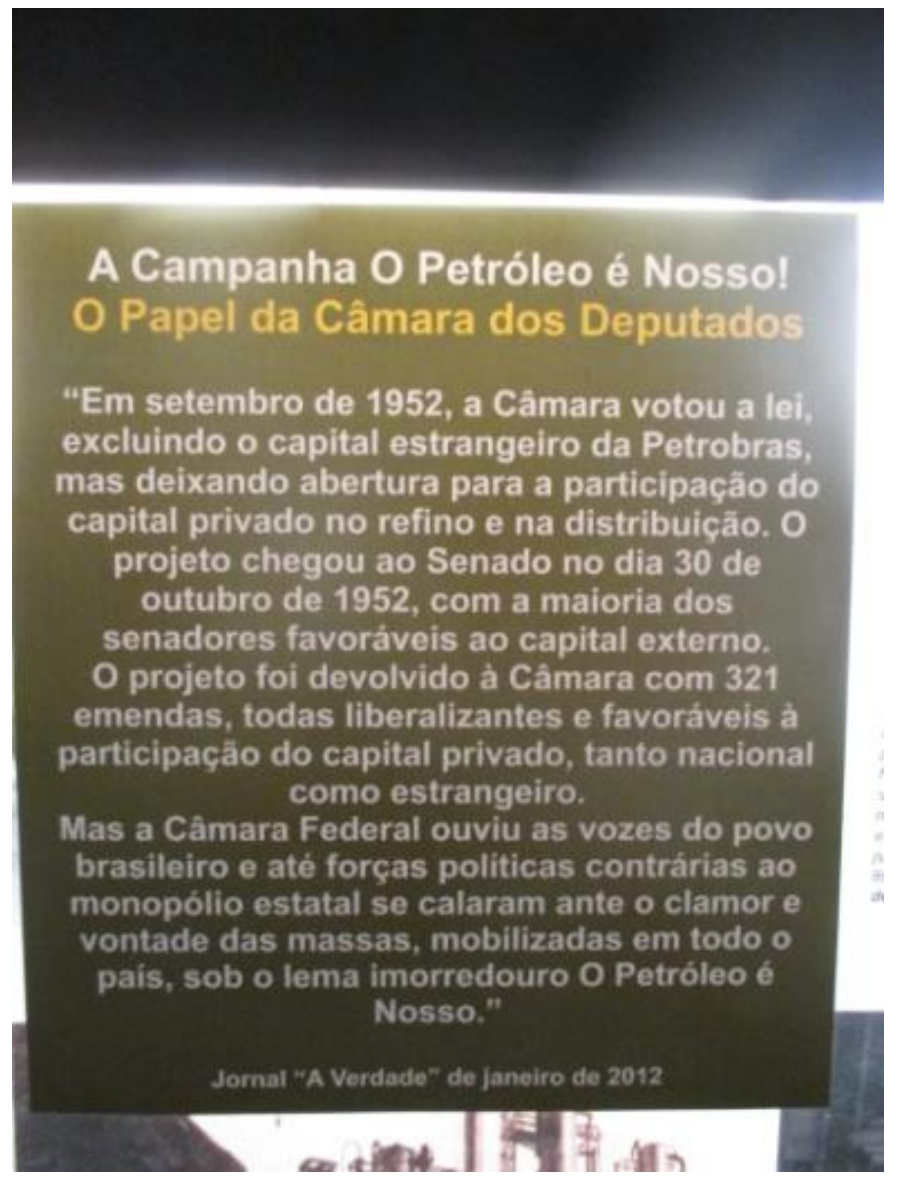

Fonte: Acervo pessoal da autora (foto da exposição Parlamento e Democracia)

Consoante Marcuschi (2008), texto é o dito, mais o não dito. A oposição ao Governo do Partido dos Trabalhadores e à esquerda política escancara-se, paradoxalmente, na omissão: a omissão de personalidades políticas parlamentares consideradas de esquerda; a omissão às quatro vitórias consecutivas do Partido dos Trabalhadores na disputa à Presidência da República do Brasil; a omissão à primeira Presidente mulher eleita no Brasil; a omissão da repercussão mundial da ascensão da classe trabalhadora (em especial do Presidente Lula) ao poder, desconsiderando este fato como fenômeno histórico digno de registro para a história democrática do País, em exposição que alega contar a história da democracia no Brasil e no mundo, com enfoque no Parlamento brasileiro.

Fatos recentes reforçam esta interpretação interdiscursiva. Em julho de 2015, o então Presidente da Câmara dos Deputados, Eduardo Cunha, anuncia o rompimento com o Governo e critica fortemente o Poder Judiciário, que o investiga por envolvimento em atos de corrupção. Ademais, instaura-se na Câmara dos Deputados processo de impeachment contra a 
Presidenta da República. Se Fairclough (2003) ressalta a poderosa estratégia discursiva de predição - repetimos, o apresentar como fato real algo que ainda não o é, algo que se quer ver concretizar no futuro - ou, em termos simples, lançar as sementes, pode-se dizer que a Secretaria de Comunicação da Câmara dos Deputados, sob a batuta do grupo hegemônico de então, assim fez: plantou as sementes em âmbito discursivo, a fim de colher as mudanças na estrutura e nas práticas sociais.

Finalmente, concluímos a análise deste cluster alertando para o fato de que as tensões sociais e discursivas entre os Poderes constituem-se em rotina das relações políticas institucionais no Brasil, que guarda duas facetas: mostram-se positivas na medida em que garantem o equilíbrio dos Poderes da República e das negociações políticas necessárias à diversidade democrática; podem mostrar-se danosas, quando se transmutam da política para a politicagem, as chantagens mútuas e as negociatas. Bonfim (2004), ao analisar os discursos de posse dos ex-Presidentes da República - e as condições em que acontecem as posses presidenciais propriamente ditas —, revela o recrudescimento frequente entre os Poderes:

O "lugar físico e institucional" de onde o empossado profere o discurso varia muito. O juramento perante o Congresso foi feito por quase todos [os Presidentes do Brasil] (excetuadas as situações revolucionárias). Mas nem sempre é no Congresso que o presidente faz o discurso [...] O clima das relações Executivo-Legislativo [...] está no centro dessa escolha. JK faz seu discurso mais significativo no TSE, que lhe assegurou a diplomação e a posse. No Congresso, não era ameno o clima. Mas João Goulart fez seu discurso no Congresso, que lhe assegurou a posse. Os presidentes militares fazem seus discursos preferenciais (exceto Castello) no Palácio do Planalto; e também por rádio e TV. Getúlio Vargas vai para a praça, em 1951, logo após o juramento solene no Congresso. 


\section{[3] Thomas Jefferson, 1743-1826}

Uma Declaração de Direitos é a garantia do povo contra qualquer governo, e contra a qual nenhum governo pode se opor ou inferir.

Figura 54 - Participante representado: Thomas Jefferson

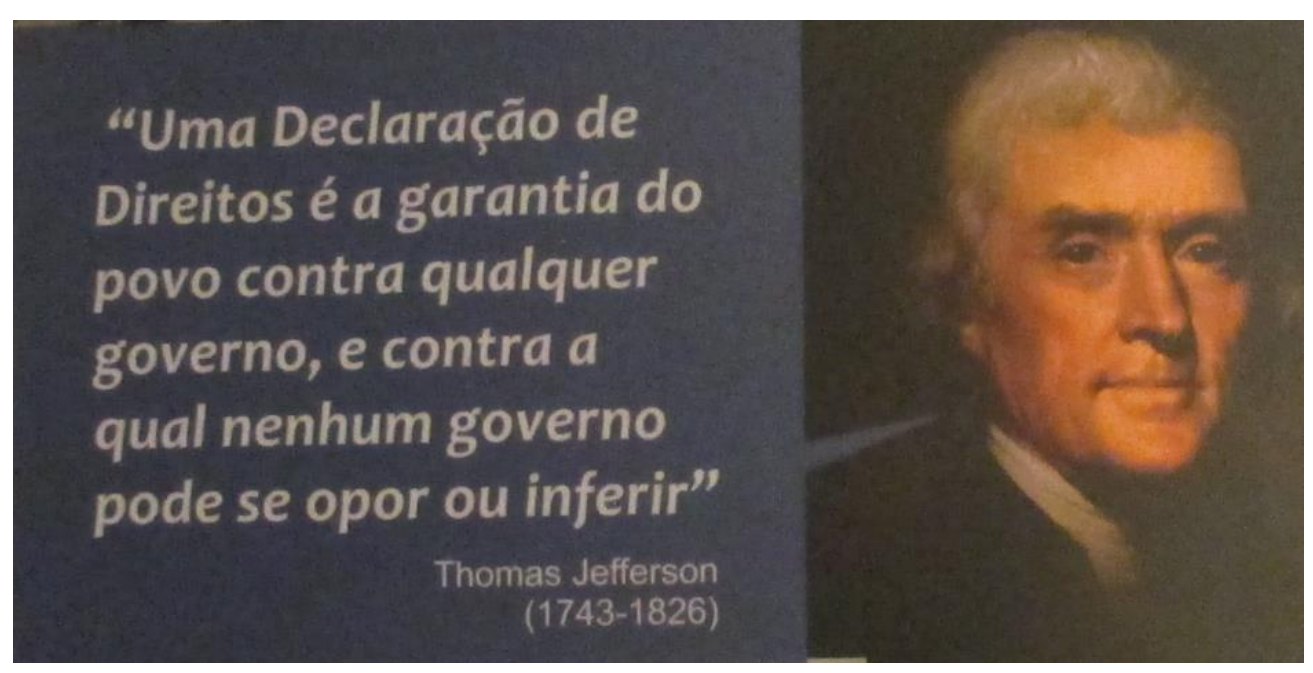

Fonte: Acervo pessoal da autora (foto do folder da exposição Parlamento e Democracia).

$\mathrm{Na}$ sentença de Thomas Jefferson incorporada ao folder, o termo "governo", recontextualizado, poderia apresentar um novo referente histórico: o Governo da então Presidenta da República, Dilma Rousseff — o inimigo oculto, já desvelado neste estudo. Expressivo é o excerto "garantia do povo contra qualquer governo". Feita a análise discursiva, e somente após a análise, a leitura se altera e o trecho parece falar, por si, o que a ele traz subjacente.

Além disso, trata-se de asserção categórica (Fairclough, 2003, p. 63), não modalizada: “A é B", e não "pode ser B" ou “deve ser B”. Nota-se, em boa parte das intertextualidades manifestas, a escolha de asserções categóricas como forma modal neutra dos textos escritos: proposições declarativas tomadas, por pressuposição, como verdadeiras. 


\section{[4] Jose Bonifácio, 1763-1838}

(...) de que serve uma constituição em papel? A constituição deve estar arraigada em nossas leis, estabelecimentos e costumes. Não são comissões militares e medidas ditatoriais que deviam restabelecer a ordem e sossegar as províncias, mas sim a imediata convocação das câmaras e um novo ministério sábio, energético e de popularidade.

Figura 55 - Participante representado: Thomas Jefferson

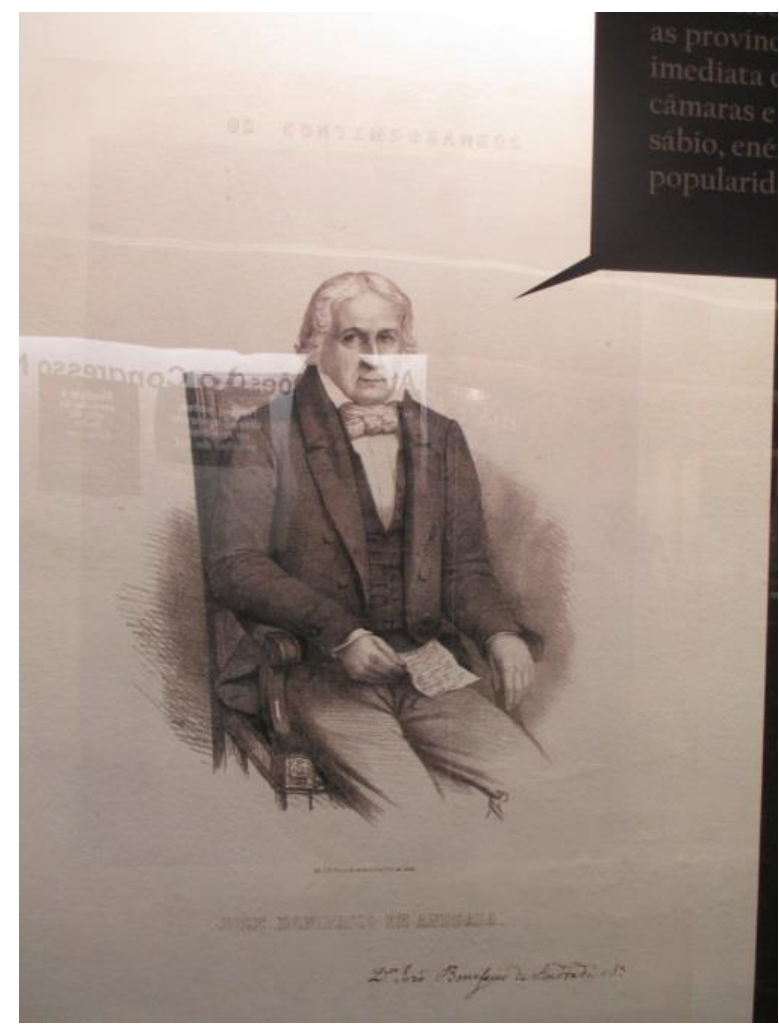

Fonte: Acervo pessoal da autora (foto da exposição Parlamento e Democracia)

Toda a força ilocucionária deste excerto inicia-se com uma indagação retórica, que é, na verdade, uma afirmação: de nada serve uma constituição em papel. Recorre-se à deôntica para afirmar a obrigação de estender a alçada constitucional não só às leis, mas também às instituições e aos costumes. Este excerto parece retomar e resumir os temas/tópicos e as perspectivas adotadas em relação a esses temas/tópicos em toda a exposição. O primeiro é a Constituição, ou seja, a legitimação do Poder em bases constitucionais e legais. Repisado, de forma reiterada, é esteio da representação parlamentar no texto constitucional.

Em segundo lugar, a oposição a regimes ditatoriais, que representam exceção à condição democrática e, por conseguinte, à própria existência do Parlamento. Novamente, o 
texto reporta-se à ordem militar como inimiga. Este inimigo, contudo, é declarado. Em terceiro lugar, a ênfase à ordem civil, à pacificação das massas: "restabelecer a ordem" e "sossegar as províncias". Em quarto lugar, a exaltação do Poder Legislativo — no caso, o poder local —, pela convocação das câmaras municipais e/ou estaduais.

Em quinto e último lugar, surgem indícios do inimigo velado, já inúmeras vezes mencionado nesta análise. E isso se dá por meio de duas estratégias discursivas: a recontextualização e a suposição. Por meio da recontextualização, recorre-se à crítica ao Ministério antigo, de um século passado, para se construir a crítica ao Ministério atual, à equipe do Poder Executivo, que encarna a representação do rival maior em toda a exposição. Por meio da análise da suposição, descortina-se a estratégia discursiva. Ao se mencionar novo Ministério que tenha os atributos "sábio, enérgico e de popularidade", contrapõe-se o pressuposto: o "atual" Ministério (o de outrora e o contemporâneo) é ignóbil, fraco, impopular.

\section{[5] Arnold Toynbee, 1852-1883.}

O maior castigo para aqueles que não se interessam por política, é que serão governados pelos que se interessam.

Figura 56 - Participante representado: Arnold Toynbee

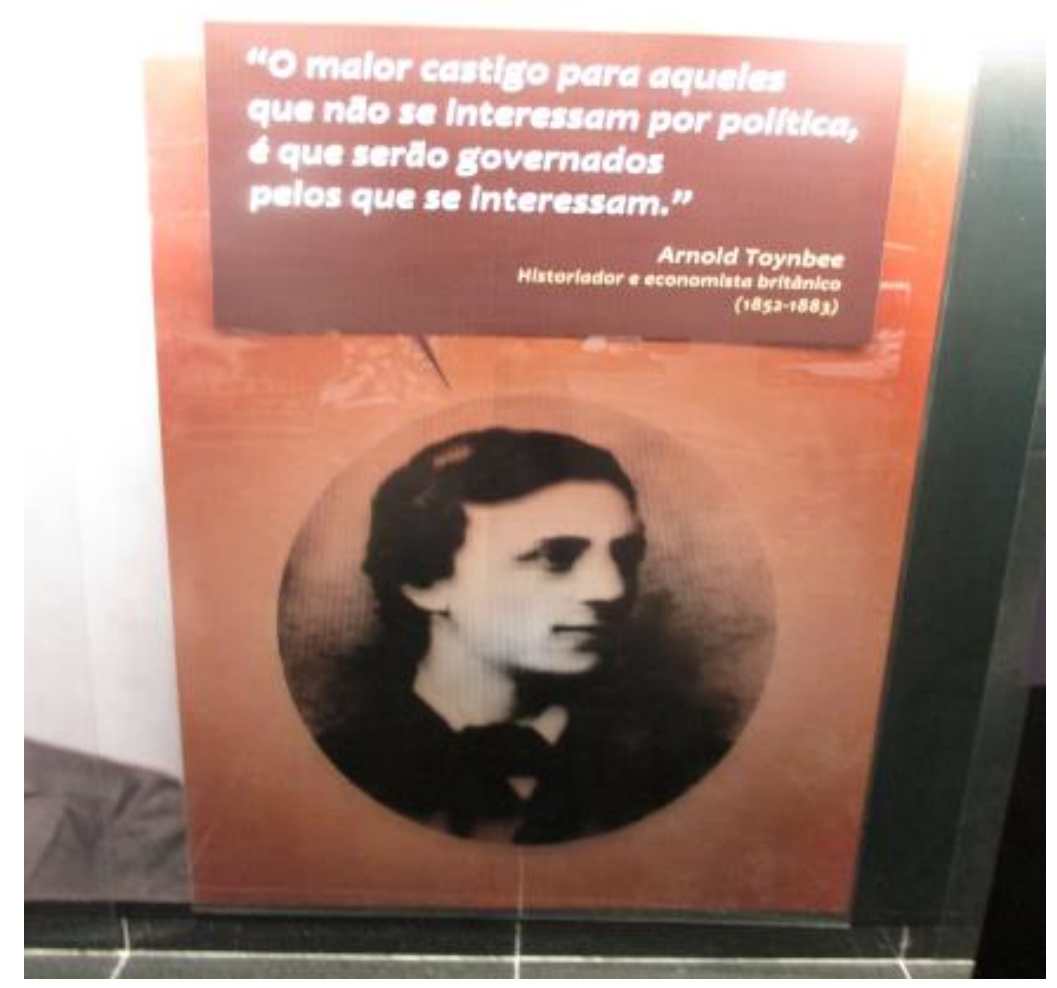

Fonte: Acervo pessoal da autora (foto da exposição Parlamento e Democracia) 
Ressalta a escolha de texto em que se emprega o termo "castigo". Novamente se recorre a vocábulos que se acomodam no campo semântico de repreensão, alerta, perigo, e estes tendo como vetor um dos participantes interativos: o cidadão, a quem se dirige o folder da exposição. Em todo o texto, este participante interativo encontra sob posição de ameaça e alerta em relação à sua conduta., que se quer ver alterada. A intertextualidade constitutiva constrói-se por meio da conformação deste campo lexical, interligando este texto a outros da exposição, uns mais explíticos, outros menos.

Neste, escancara-se o "dedo em riste", primeiro aos visitantes e à sociedade em geral: "Ao resgatar a história, a exposição traz o alerta: qualquer regime que cale a voz das ruas, censure a imprensa e enfraqueça o Poder Legislativo merece repúdio." Note-se a contradição que se vai construindo: o povo deve manifestar-se, pois não se pode calar a voz das ruas; mas deve fazê-lo por meio do Parlamento, que o representa.

\section{[6] Joaquim Nabuco, 1849-1910.}

Nenhuma reforma política produzirá o efeito desejado enquanto não tivermos extinguido de todo a escravidão, isto é, a escravidão e as instituições auxiliares.

Figura 57- Participante representado: Joaquim Nabuco

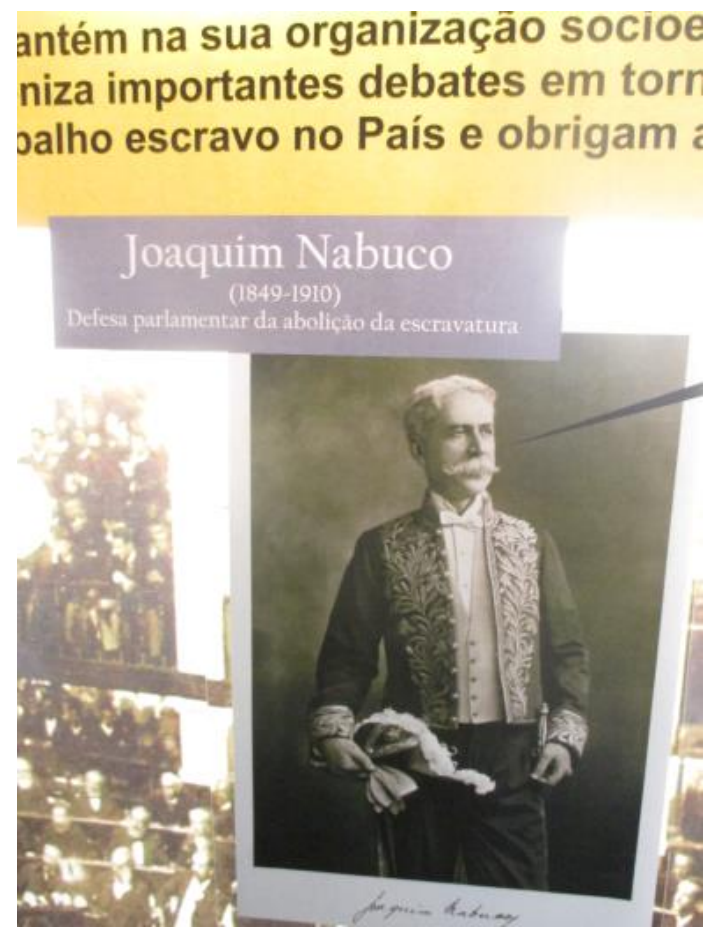

Fonte: Acervo pessoal da autora (foto da exposição Parlamento e Democracia) 
Também neste texto, percebe-se a ocorrência expressiva da recontextualização. Em voga no Parlamento de 2015, a reforma política veio como resposta às manifestações populares, pela insatisfação com o quadro político. De fato, em 10 de fevereiro de 2015, instalou-se na Câmara dos Deputados do Brasil a Comissão Especial destinada a efetuar estudo e apresentar propostas com relação às matérias infraconstitucionais da Reforma Política (CEREFPOL), amplamente divulgada. Na prática, houve uma espécie de microrreforma e pouco mudou. Entre as mudanças - em verdade, houve poucas tornaram-se ainda mais obscuros e insondáveis os financiamentos privados aos partidos políticos e a seus membros. Com isso, a construção dos signficados globais do texto multimodal tende à mantença das hegemonias historicamente estabelecidas e consolidadas. Houve muito alarde midiático quanto à reforma política iniciada na $55^{\mathrm{a}}$ Legislatura, entretanto poucas foram as alterações no sistema político como um todo.

Quanto à menção à escravidão e às instituições auxiliares, nada se encontrou no contexto histórico hodierno que permita apontar, categoricamente, o intento de recontextualização. Poder-se-ia aduzir pelo contexto político — mas não por meio de identificação de pressuposto, ou seja, não no nível léxico-gramatical, pois os elementos textuais neste nível não o permitem —, que se poderia referir-se à dependência política do Legislativo em relação ao Executivo. Ou se poderia identificar as instituições auxiliares da escravidão como aquelas ligadas ao Governo. Não há, neste caso, como afirmá-lo.

De toda sorte, o que se pode asseverar é que o texto não esclarece quem seriam as tais "instituições auxiliares" da escravidão. Tal omissão, certamente, é estratégica, e marca o não comprometimento do produtor e do replicador do signo.

Também não se sabe qual seria o "efeito desejado", o que seria um movimento contrário à recontextualização: haveria uma descontextualização. Nesse sentido, nota-se, também, uma suposição moral, pois se considera que seria bom ou desejável tal reforma.

Finalmente, o emprego do artigo "as", anteposto a "instituições auxiliares" conforma uma suposição existencial (FAIRCLOUGH, 2003, p. 77), que leva o leitor a tomar como verdadeiro o fato de que existem tais entes. 


\section{[7] Rui Barbosa, 1849-1923.}

A pior democracia é preferível à melhor das ditaduras. O homem que não lutar pelos seus direitos não merece viver.

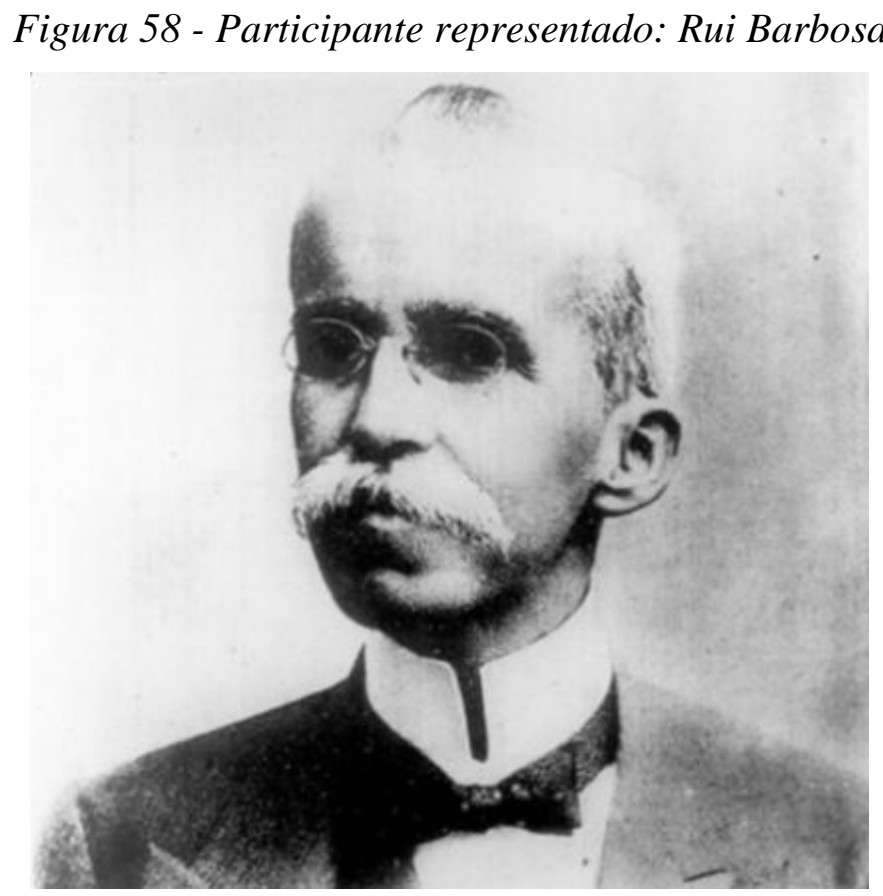

Fonte: Acervo da Câmara dos Deputados.

Em ambas as sentenças, é possível identificar modo geral de operação da ideologia (THOMPSON, 1995) denominado dissimulação, que se concretiza por meio de estratégia típica de construção simbólica, o tropo ou, mais precisamente, a hipérbole. Esta consiste em um uso figurativo da linguagem que dá à mensagem importância exagerada, que tem o fito de inculcar no interlocutor uma ideia ou imagem de tal forma que seja difícil esquecê-la.

Ao retomar o tema central da exposição, a democracia, que conforma o próprio Parlamento, busca-se proteção contra as críticas do povo e da mídia comercial à Câmara dos Deputados: mesmo o pior Parlamento deve se antepor à melhor das ditaduras. Ao analisar a interdiscursividade ou intertextualidade constitutiva, notamos que teitera tal entendimento duas outras falas selecionadas para o propecto da exposição cultural - e esta, relembra-se, dirige-se aos visitantes em geral.

A primeira fala é a de Mário Covas. Trata-se da reprodução de trecho do pronunciamento oral feito da tribuna da Câmara dos Deputados em 1968, às vésperas da publicação do Ato Institucional $\mathrm{n}^{\circ} 5$, que recrudesceu a ditadura militar então implantada no Brasil, fala a seguir trasladada e analisada. 
[8] Mário Covas, 1930-2001.

Creio no regime democráico, que não se confunde com anarquia, mas que em instante algum possa rotular ou mascarar a tirania. Creio no Parlamento, ainda que com suas demasias e fraquezas, que só desparecerão se o sustentarmos livre, soberano e independente.

Figura 59 - Participante representado: Mário Covas

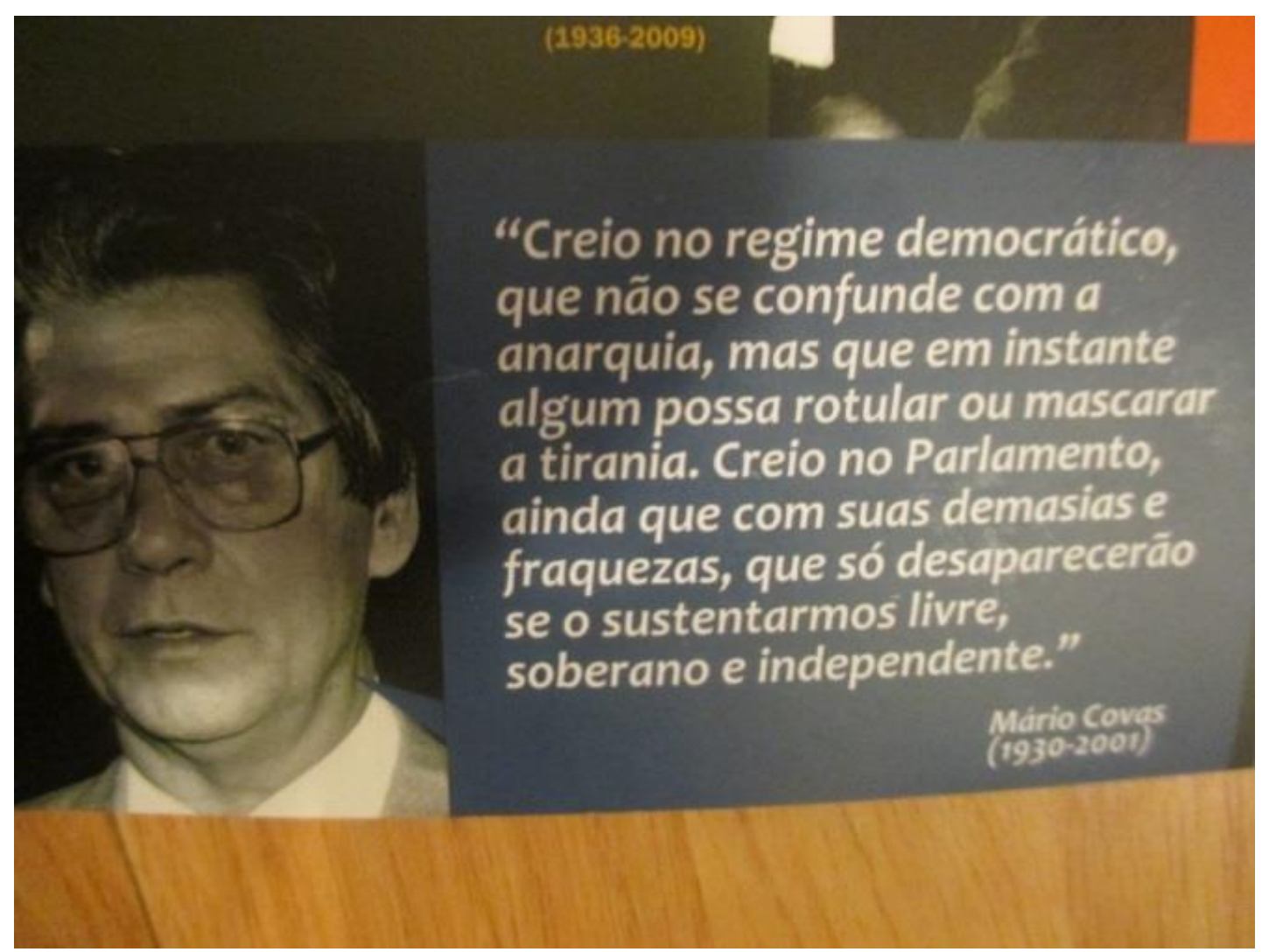

Fonte: Acervo pessoal da autora (foto do folder da exposição Parlamento e Democracia)

Acresça-se à defesa do Parlamento e do regime democrático outro propósito na transcrição da fala de Covas, a que também se chega pela análise interdiscursiva: construir o argumento contrário à anarquia, mas esta recontextualizada e ressignificada. Trata-se de manifestação de repúdio à "anarquia", aqui ressignificada como "violência", "bagunça", "caos", proveniente dos movimentos populares de rua, iniciados em 2013 e repetidos, com configurações diversas, até o ano de 2015.

A segunda fala que reforça o discurso de Rui Barbosa em defesa da democracia (" $A$ pior democracia é preferível à melhor das ditaduras.") é a de Winston Churchill, exPrimeiro-Ministro do Reino Unido entre 1940 e 1945, e 1951 e 1955, considerado político conservador. Traslada-se, a seguir, o texto selecionado pelo produtor da mostra cultural. 
[9] Winston Churchill, 1874-1965.

A democracia é a pior forma de governo, com exceção de todas as demais.

Figura 60 - Participante representado: Winston Churchill

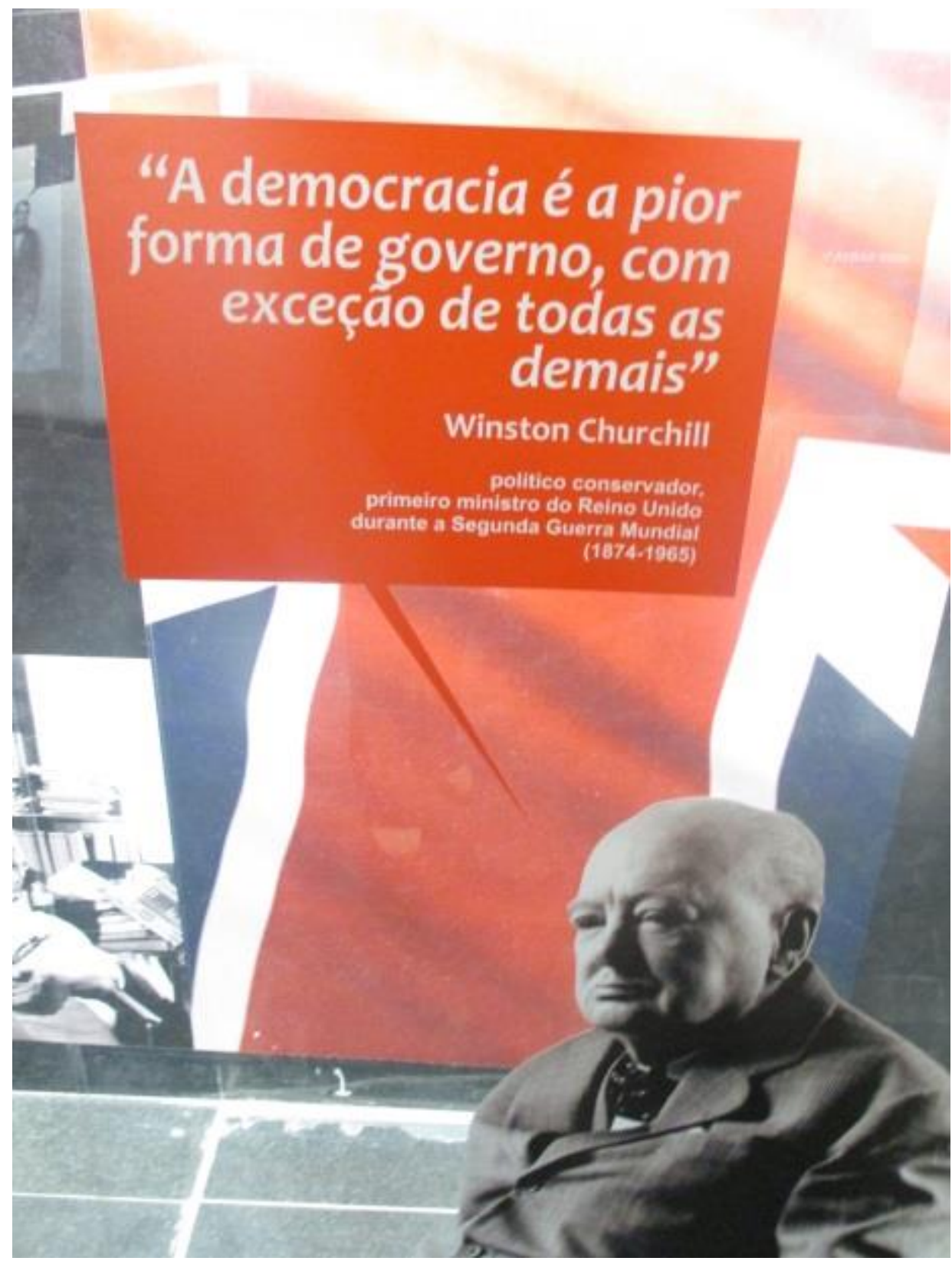

Fonte: Acervo pessoal da autora (foto da exposição Parlamento e Democracia)

$\mathrm{Na}$ próxima imagem, foto da exposição histórica, retrata-se como participante representada a primeira Deputada da Câmara dos Deputados do Brasil, em 1933, Carlota Pereira de Queirós. Interessante notar como a Parlamentar se mostra destacada, em saliência 
na imagem, com vestido e chapéu brancos, entre os homens Deputados Federais que trajam preto. Para Kress e van Leeuwen (2001), a cor tem força extraordinária na inter-relação discursiva e articula os discursos. Trata-se de modo inteiramente distinto da linguagem, mas indispensável para a descrição do texto multimodal. Na imagem, desencaixada do contexto geral, desenturmada, a figura angelical da Deputada parece carregar outros atributos também associados à cor branca: pureza, fragilidade, inocência, virgindade.

\section{[10] Carlota Pereira de Queirós, 1892-1982.}

Além de representante feminina, única nesta Assembleia, sou, como todos os que aqui se encontram, uma brasileira, integrada nos destinos do seu país e identificada para sempre com os seus problemas (...)

\section{Figura 61 - Participante representada: Carlota de Queirós}

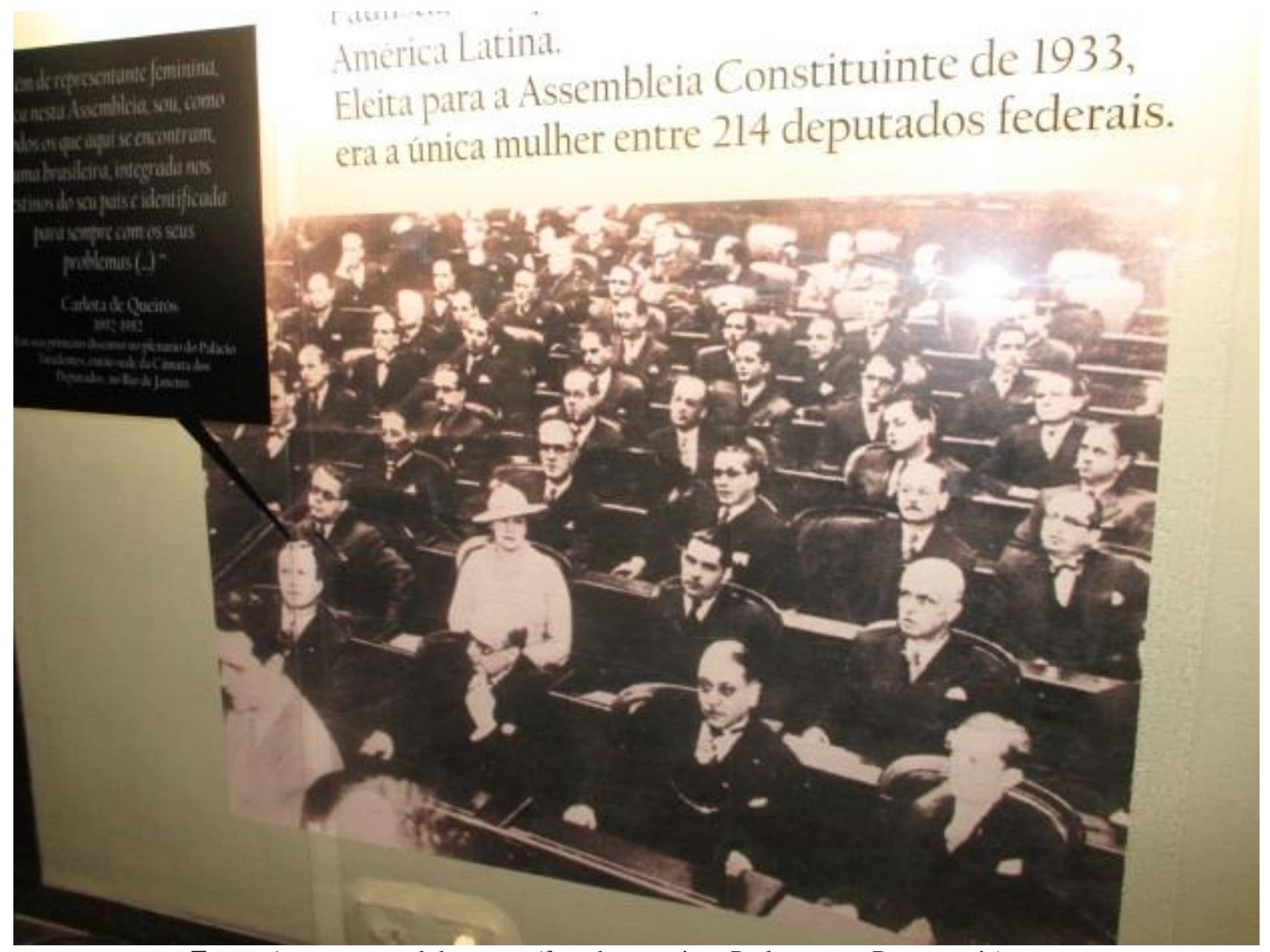

Fonte: Acervo pessoal da autora (foto da exposição Parlamento e Democracia) 
Segundo Fairclough (2001, p. 208), os agentes sociais podem ser incluídos ou excluídos da representação dos eventos sociais, sendo que a exclusão se dá de duas formas: o agente é suprimido, ou seja, não há nenhuma menção no texto a ele; ou o agente é relegado a segundo plano. No caso da representação de mulheres, como já dissemos em outro ponto da análise discusiva crítica e multimodal, a primeira menção que se pode fazer é a representação ínfima das mulheres em toda a exposição de arte, ou seja, foram agentes sociais relegados a segundo plano. Foram excluídas da representação parlamentar na capa do panfleto e parcamente mencionadas (apenas uma foto de uma parlamentar, em condições desprivilegiadas no significado composicional) no interior do folder.

Note-se, no texto do modo escrito, o esforço da Deputada para integrar-se a meio historicamente - e ainda hoje, em 2015 — ocupado por homens, ao dizer que ela é, "como todos os que aqui se encontram, uma brasileira, integrada nos destinos do seu país e identificada para sempre com os seus problemas" (grifo nosso). Por meio do modo geral de operação da ideologia chamado por Thompson (1995) de unificação, busca-se a conexão da identidade individual da Parlamentar com a identidade institucional a que a Parlamentar pertence, marginalizada inclusive na mostra cultural, já que se verifica a presença majoritária de homens (parlamentares, políticos, filósofos, intelectuais) em toda a exposição e no folder. Neste, todos foram representados (retratados) de forma pessoal, devidamente nomeados e localizados historicamente por meio do registro de suas datas de nascimento e falecimento.

Abre-se um parêntese para observar que a exclusiva menção a agentes sociais já falecidos é, de fato, forma de registro histórico - a exposição busca contar a história da democracia, ainda que de forma parcial e monocórdica - , mas certamente é também modo de isentar-se politicamente quanto a opiniões ainda passíveis de crítica e defesa. Destarte, reitera-se: não há agentes sociais (participantes representados) retratados e nomeados que pertençam a partidos considerados de esquerda ou de oposição ao então partido detentor da Presidência da Câmara, o Partido do Movimento Democrático do Brasil (PMDB) e ao então Presidente da Casa, o Deputado Eduardo Cunha. 
[11] Ulysses Guimarães, 1916-1992.

A democracia é o regime em que os governados mudam os governantes e, sem violência, fazem mudanças com, ou mesmo contra, a vontade dos governantes.

\section{Figura 62 - Participante representado: Ulysses Guimarães}

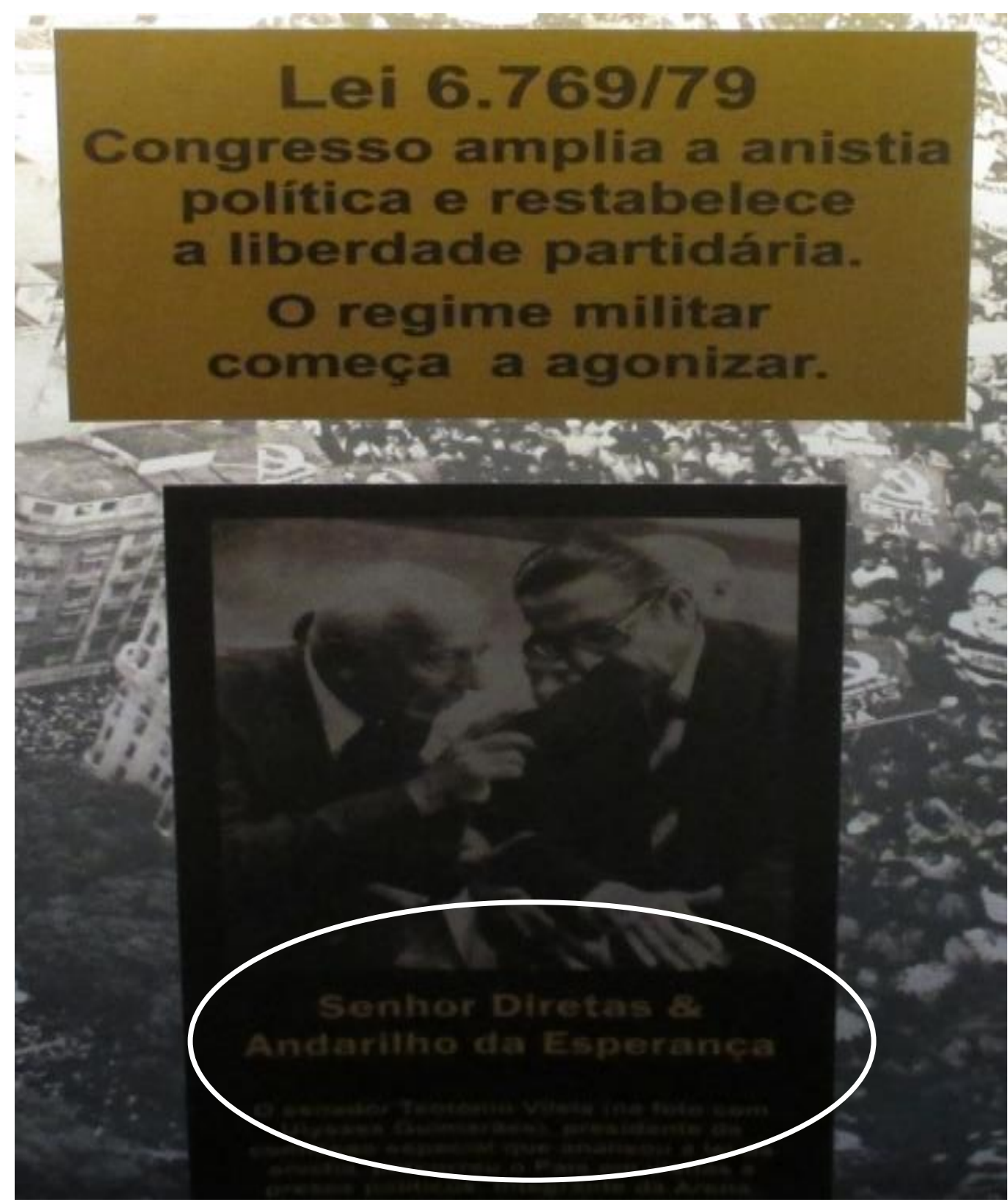

Fonte: Acervo pessoal da autora (foto da exposição Parlamento e Democracia).

A reprodução da fala de Ulysses Guimarães é bastante expressiva, pela própria identidade social do autor da frase, reconhecido nacionalmente como personalidade histórica e membro histórico do PMDB, partido que, como já dito, lidera o grupo hegemônico da Câmara dos Deputados do Brasil. A imagem de Ulysses Guimarães atrela-se à da 
Constituição de 1988, tendo em vista a construção identitária que se promoveu à época, e ainda se promove, para a pessoa do político já falecido, mas ainda cultuado, o qual recebe na exposição os dísticos: Senhor Diretas e Andarilho da Esperança.

A interdiscursividade reforça, contudo, o propósito de alerta à população em geral para os riscos que movimentos populares violentos representam para a democracia, definida como "regime em que os governados mudam os governantes e, sem violência, fazem mudanças com, ou mesmo contra, a vontade dos governantes” (grifo nosso).

Figura 63 - Diretas Já e Anistia.
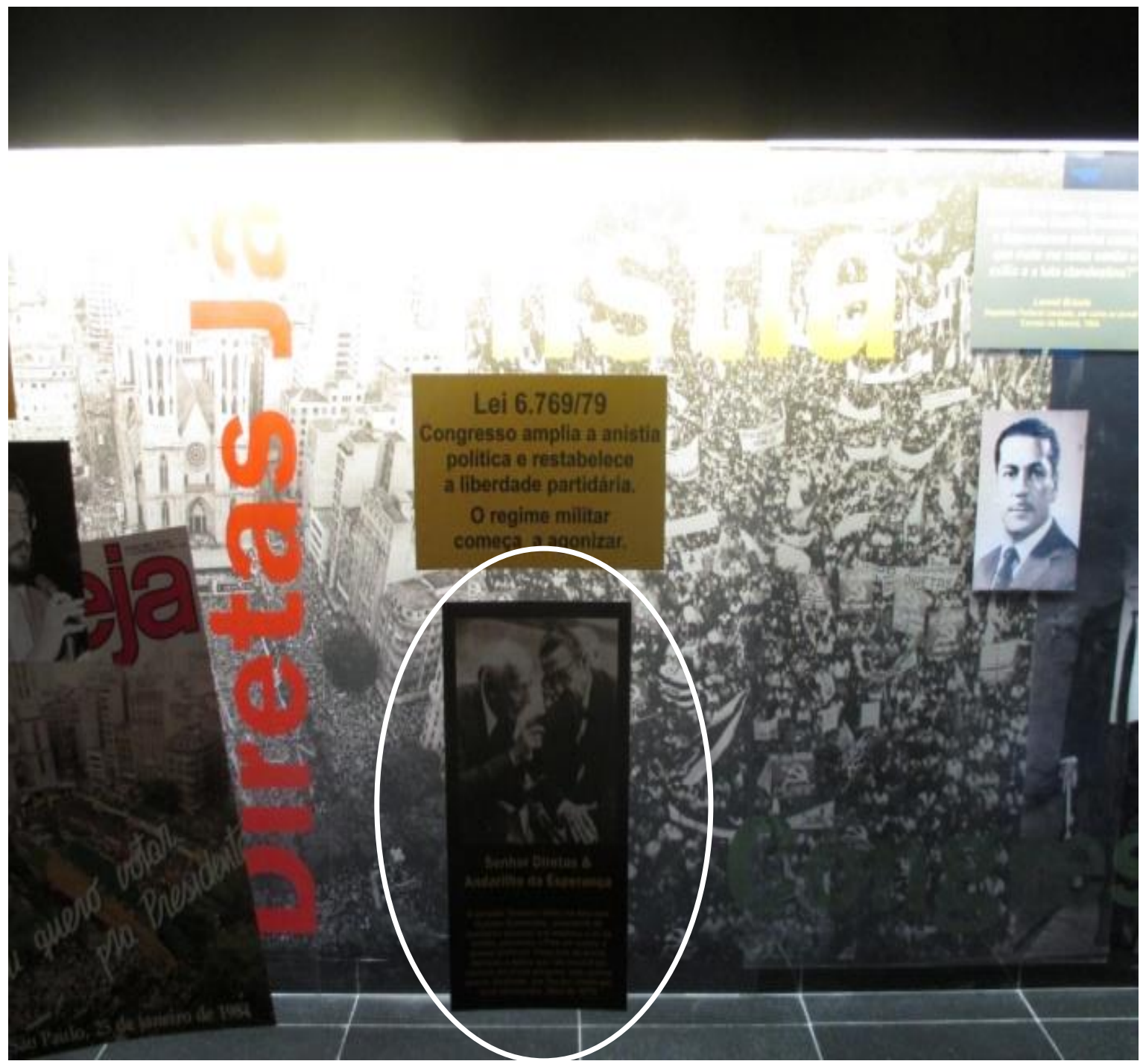

Fonte: Acervo pessoal da autora (foto da exposição Parlamento e Democracia) 


\subsubsection{Análise discursiva crítica e multimodal dos textos exordiais da exposição}

Intrigante notar que os textos escritos de boas-vindas da exposição dirigem-se a dois interlocutores. O texto principal, estampado na parede do corredor de acesso ao Salão Verde e ao Plenário, parede com altura aproximada de 2 metros, em um dos corredores mais movimentados da Casa, inicia-se com o seguinte vocativo e saudação (Figura 22): "Caro Parlamentar, seja bem-vindo à Câmara dos Deputados [...]”. Faz crer que toda a exposição e seus textos multimodais dirigem-se aos Parlamentares recém-empossados. Entretanto, o texto escrito do folder explicativo da mostra dirige-se aos visitantes em geral e apresenta variações textuais sutis, mas bastante significativas e relevantes para a análise discursiva crítica.

Neste momento do trabalho, faz-se o cotejo dos textos - [A], dirigido aos visitantes em geral, e [B], dirigido aos Parlamentares recém-empossados - , com esteio na triangulação teórica que o estudo propôs e na integração dos métodos e preceitos, conforme já se anunciou, a fim de entender a diversidade dos participantes interativos ou interlocutores. Busca-se, enfim, desvelar alguns meandros da ideologia ocultados nos textos. Os excertos discordantes marcam-se em vermelho.

\begin{tabular}{|c|c|}
\hline $\begin{array}{c}\text { [A] TEXTO DIRIGIDO AOS } \\
\text { VISITANTES DA EXPOSIÇÃO } \\
\text { (Suporte: folder multimodal impresso, } \\
\text { distribuído em avulso.) }\end{array}$ & $\begin{array}{c}\text { [B] TEXTO DIRIGIDO AOS } \\
\text { PARLAMENTARES RECÉM- } \\
\text { EMPOSSADOS } \\
\text { (Suporte: cartaz multimodal impresso, } \\
\text { colado na parede.) }\end{array}$ \\
\hline
\end{tabular}

\begin{tabular}{|l|l|}
\hline [1-A] Seja bem-vindo à Câmara dos & [1-B] Caro Parlamentar, \\
Deputados & Seja bem-vindo à Câmara dos Deputados, \\
Aqui trabalham brasileiros escolhidos por & onde todos são iguais na missão de \\
cada um de nós para representar e e & representar e defender o interesse do \\
defender o interesse do povo, fiscalizar e & povo, fiscalizar o governo e fazer leis que \\
fazer leis que possam melhorar a vida dos & possam melhorar a vida dos cidadãos. \\
cidadãos. & \\
\hline
\end{tabular}

Em [1-A] nota-se a utilização do modo geral de operação da ideologia chamado unificação, tendente à busca de identidade coletiva. "Aqui trabalham brasileiros", ou seja, brasileiros como nós todos somos; e estes brasileiros foram escolhidos por nós, portanto 
somos todos nós, cidadãos, corresponsáveis por essa escolha. Relaciona-se a este modo de operação ideológica um segundo, o de legitimação, por meio da racionalização, baseada em normas positivas: se foram escolhidos por nós, com esteio em nossa constituição e em nossas leis infraconstitucionais, têm legitimidade.

Quanto à integração dos modos semióticos, o sentido do verbo "trabalham" no texto escrito, em pressuposição, robora e integra o sentido construído pelas imagens: as representações visuais dos Parlamentares pelo órgão midiático da Câmara dos Deputados sistematicamente os retrata com a boca aberta (cf. pintura da capa do panfleto), diante de um microfone, com papéis na mão, em pé no plenário ou em reuniões, enfim, trabalhando. Tratase de um esforço no sentido de desconstruir jargões populares que propagam a identidade do político como alguém que não trabalha.

\section{Jornal da Câmara} Jornal da Câmara
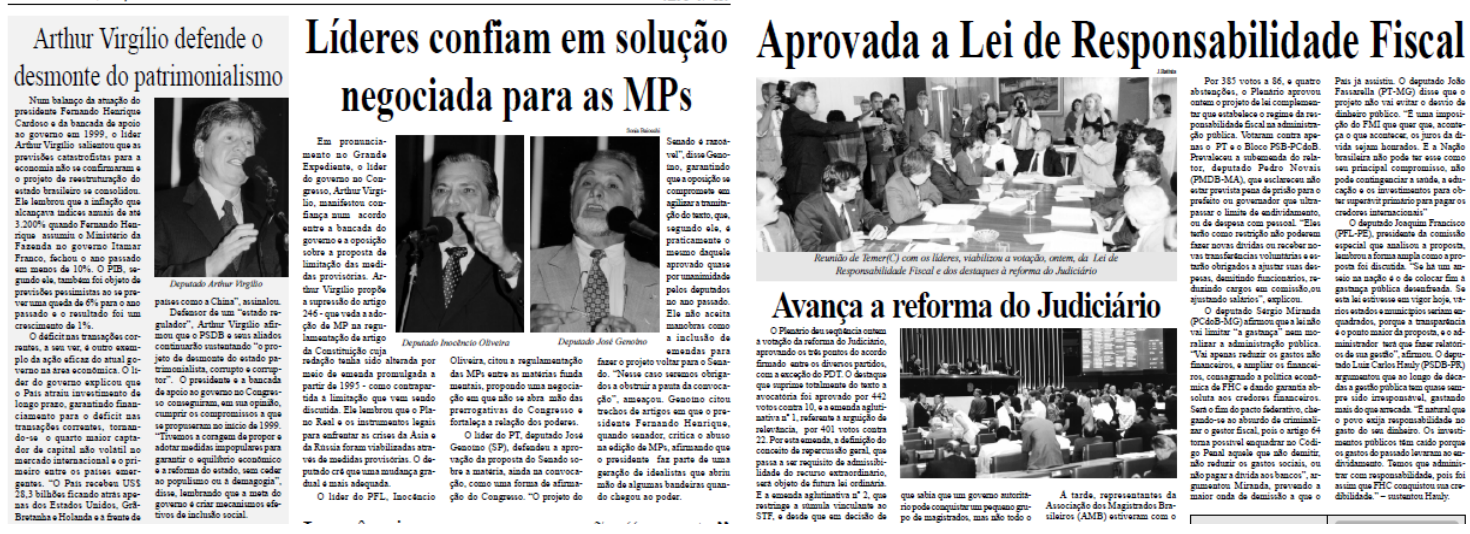

Fonte: Acervo da Câmara dos Deputados.

Em [1-B], explicita-se a estratégia típica de construção simbólica chamada unificação, com o fito de mitigar as dissensões políticas que há dentro do próprio Parlamento, entre seus membros, e o acesso às decisões políticas ali havidas. Negam-se ou ocultam-se as relações de dominação política. 


\begin{tabular}{|c|c|}
\hline $\begin{array}{l}\text { [2-A] Nesta Casa transparente e aberta a } \\
\text { todos, o presente e o futuro do País estão em } \\
\text { permanente construção. Essa é a essência da } \\
\text { política. }\end{array}$ & $\begin{array}{l}\text { [2-B] Nesta Casa transparente e aberta a } \\
\text { todos, o presente e o futuro do País estão } \\
\text { em permanente construção. Essa é a } \\
\text { essência da política. }\end{array}$ \\
\hline
\end{tabular}

Em [2-A], os atributos da Casa de Leis — transparente e aberta a todos — apresentamse como essência e inerência, já que não estão isolados por vírgulas explicativas. Trata-se da Casa do Povo, descerrada e acessível a todos.

Acrescente-se ainda que, para Fairclough (2001, p. 137), muitas ambivalências textuais originam-se da intertextualidade. Na segunda sentença, a intertextualidade discursiva constrói a ambivalência, pois o demonstrativo anafórico "essa" não indica a sua referência anafórica. Indaga-se: qual seria, enfim, a essência da política?

\begin{tabular}{|l|l|}
\hline [3-A] O dia a dia de cada brasileiro & [3-B] O dia a dia de cada brasileiro passa \\
passa pelas decisões tomadas no Plenário & pelas decisões tomadas no Plenário e nas \\
e nas comissóes. São centenas de matérias & comissões. O que acontece aqui é público e de \\
apreciadas por ano, votadas após & conhecimento geral. O povo tem o direito de \\
intensos debates. Algumas delas exigem & saber e a Casa tem o dever de informar. \\
dezenas de reunióes, dias e noites de & São centenas de matérias apreciadas por ano, \\
negociaçôes, discussóes que varam a a & votadas após intensos debates. Algumas delas \\
madrugada à procura de consensos e exigem dezenas de reuniões, e noites de \\
acordos.
\end{tabular}

No dizer preciso de Fairclough (2001, p. 144 e 147),

Os grupos poderosos são representados como se falassem na linguagem que os próprios leitores poderiam ter usado, o que torna muito mais fácil de adotar os seus sentidos. Pode-se considerar que a mídia de notícias efetiva o trabalho ideológico de transmitir as vozes do poder em uma forma disfarçada e oculta.

Em [3-A], a aproximação o cidadão se concretiza por meio da informalização, como em "discussões que varam a madrugada", o que também intenta mostrar que o Parlamentar trabalha muito. Em [3-B], bem diferentemente, o sentido se constrói sob o abrigo do alerta, da cautela e da precaução: o Parlamentar precisa saber que está sendo vigiado. A integração dos 
recursos semióticos permite que outras imagens e textos da exposição, em relação interdiscursiva, roborem este entendimento. Na primeira foto, o Parlamento é visto de cima, como se vigiado por uma entidade superior, que poderia ser a sociedade e o cidação. $\mathrm{Na}$ segunda foto, o alerta de Padre Feijó (1784-1843) — um representante da Igreja — em relação ao comportamento do Parlamentar, que se deve guiar pela prudência e cautela, a bem da própria imagem do Parlamento: "A prudência é o único farol que deve marchar diante do legislador." Em todos os casos, os Parlamentares estão sob vigilância, ou do cidadão, ou da instituição Parlamento.

Figura 65 - Entrada da exposição Parlamento e Democracia

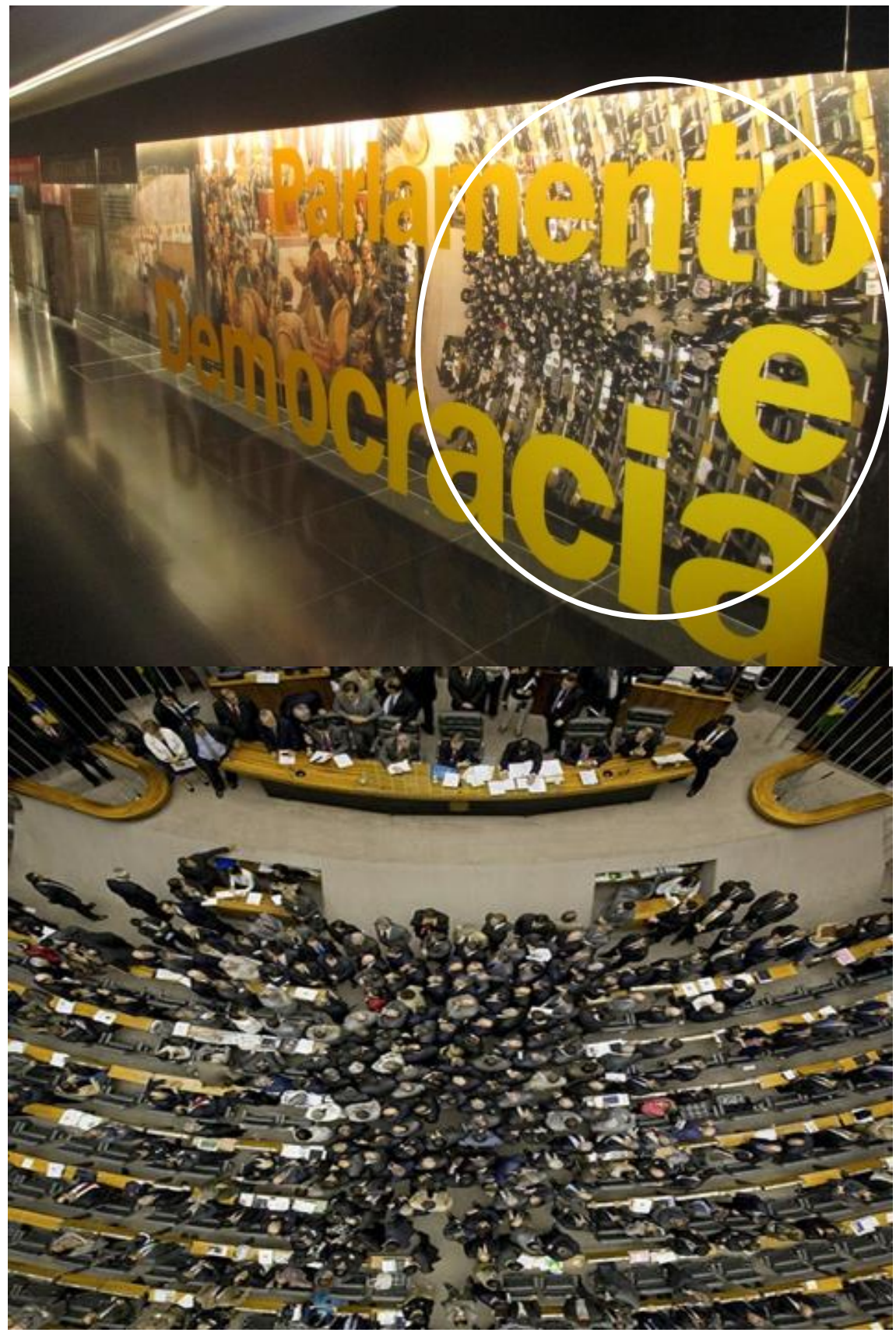

Fonte: Foto da exposição Parlamento e Democracia.. 
Figura 66 - Participante representado: Padre Feijó

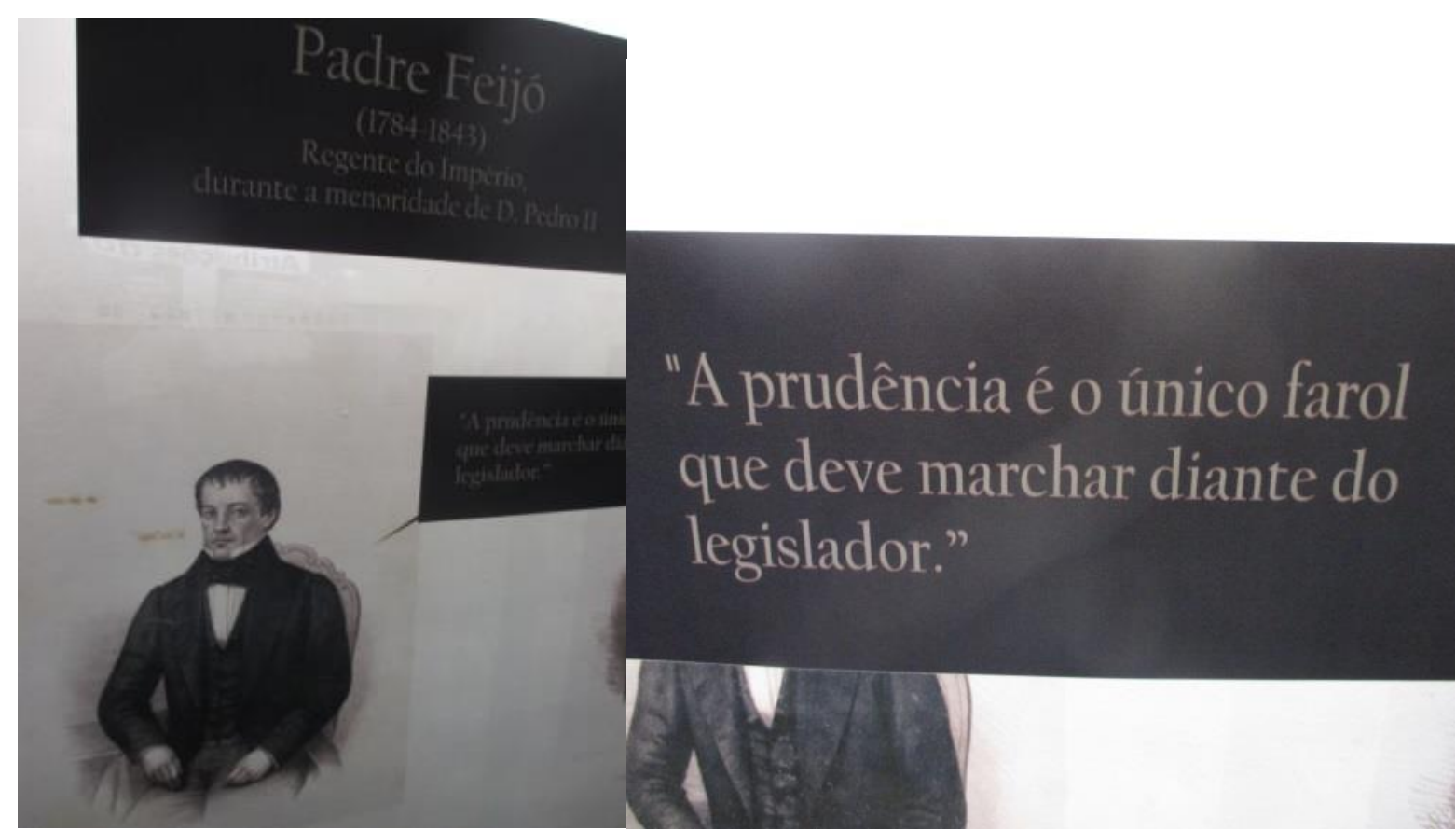

Fonte: Foto da exposição Parlamento e Democracia..

\begin{tabular}{|l|l|lr|}
\hline [4-A] O Parlamento é o berço da & [4-B] O Parlamento é o berço da democracia, \\
democracia, da prática sagrada do do & da prática sagrada do diálogo e da liberdade. \\
diálogo e da liberdade. Não há & Não há democracia forte sem um Legislativo \\
democracia forte sem um Legislativo & forte, que represente o povo na sua \\
forte, que represente o povo na sua & diversidade e plenitude. & \\
diversidade e plenitude. Desde a Grécia & & \\
Antiga, alguns cidadãos decidem questões & \\
importantes em nome do conjunto da & \\
sociedade. Ao longo do tempo, a forma de & \\
escolher os representantes populares & \\
evoluiu, na busca de modelos capazes de & \\
refletir com mais fidelidade o que pensam & \\
e o que querem todos os cidadãos. & \\
\hline
\end{tabular}

Em ambos os textos [4-A e 4-B], há a sacralização ou deificação do Parlamento, numa estratégia típica de construção simbólica denominada de eternalização (THOMPSON, 1995): a democracia é prática sagrada do diálogo e da liberdade. O texto dirigido ao cidadão [4-A] mostra a democracia como condição inerente à sociedade, já que desde muito antigamente (Grécia Antiga) alguns decidiam em nome do conjunto. Trata-se a democracia de forma reificada, modo de operação ideológica (Ibid.) que retrata as situações históricas como eternalizadas, atemporais, permanentes. Essa condição democrática, embora atemporal, 
aperfeiçoou-se em benefício do cidadão, por meio do aprimoramento das formas de escolha dos representantes populares, segundo o texto exposto.

[5-A] A exposição Parlamento e Democracia, que marca o início dos trabalhos da $55^{a}$ Legislatura em $1^{\circ}$ de fevereiro de 2015, apresenta a evolução da representação popular no mundo ao longo dos séculos, com ilustrações e textos de filósofos e pensadores das diversas épocas.
[5-B] A exposição Parlamento e Democracia apresenta a evolução da representação popular no mundo ao longo dos séculos, com ilustrações e textos de filósofos e pensadores das diversas épocas.

Entende-se que [5-A] informa o visitante acerca do contexto institucional e histórico em que se expõe a mostra cultural, ao mesmo tempo em que lhe dá o caráter de oficialidade, pois informa que se trata da $55^{\mathrm{a}}$ Legislatura da Câmara dos Deputados do Brasil.

[6-A] A mostra também lembra a história da Câmara dos Deputados desde a Assembleia Constituinte de 1823, numa homenagem aos brasileiros que contribuíram para construir uma naçãocontinente e consolidar as instituições democráticas.
[6-B] A mostra também conta a história da Câmara dos Deputados desde a Assembleia Constituinte de 1823, numa homenagem aos brasileiros que contribuíram para construir a nação e consolidar as instituições democráticas.

Ao afirmar que a mostra é uma "homenagem aos brasileiros que contribuíram para [...] consolidar as instituições democráticas" [6-A e 6-B], pressupõe-se que as instituições democráticas estão consolidadas. Trata-se de repisar o entendimento de que a democracia é factual, inarredável, inalienável. Poder-se-ia identificar, também, a estratégia típica de construção simbólica chamada naturalização, do modo de operacionalização da ideologia denominado reificação (THOMPSON, 1995): as instituições democráticas derivar-se-iam de uma ordem social natural e inevitável, própria da organização social humana.

Em [6-A], a nação é adjetivada como nação-continente, numa ênfase à grandeza do País em sentido denotativo. Ccontudo, é na metáfora que se edifica o sentido do atributo: é ao trabalho relevante e incansável da Câmara dos Deputados, desde 1823, que se deve a construção da imensa nação brasileira. 
[7-A] Ao resgatar a história, a exposição traz um alerta: qualquer regime que cale a voz das ruas, censure a imprensa $e$ enfraqueça o Poder Legislativo merece repúdio. A legitimidade das decisões políticas está na representação que decorre do voto direto e universal. Os parlamentares são mandatários da vontade do povo.
[7-B] Ao resgatar a história, a exposição nos lembra: a representação política é legítima quando baseada na vontade do povo, que se manifesta no voto. Qualquer regime que cale a voz das ruas e enfraqueça o Poder Legislativo deve ser combatido.

Em [7-A], o alerta dirige-se à sociedade em geral, com menção especial à imprensa, para que todos se mantenham alerta quanto a insurreições que ponham em risco o regime democrático. O termo "merece repúdio" - cuja carga semântica se sobreleva em relação a "deve ser combatido" [7-B], em termos de comoção — dirige-se ao cidadão. Reitera-se a construção da legitimidade do Parlamento pelo princípio democrático.

Vale notar que, no campo da retórica - aqui se a invoca suplementarmente —, podese dizer que no texto dirigido aos Parlamentares prevalece a retórica argumentativa baseada no convencimento (razão), enquanto no texto dirigido ao cidadão e à imprensa prevalece a retórica argumentativa baseada na emoção (persuasão). A ambos, toda a força perlocucionária do discurso (ameaça), no sentido de que todos devem manter-se alerta e vigilantes na defesa da democracia e do Parlamento.

Bonfim (2004, p. 15) minudencia a diferença:

Para persuadir, o orador procura compartilhar valores, sentimentos com o ouvinte, procura despertar sua compaixão por determinada pessoa ou causa, ou seu repúdio por um ato considerado vil; constrói uma empatia de tal modo que a realização do orador será a da pessoa que foi persuadida. A persuasão lida com os afetos. $\mathrm{O}$ convencimento trata da racionalidade: apresenta motivos, causas, provas. Provas são fatos passíveis de observação, objetos, de técnica ou ciência (estatísticas, estudos, experimentos, por exemplo). Mas podem ser arroladas como provas muitíssimas outras evidências: contar uma história, citar uma autoridade no assunto, etc. 
[8-A] Entre. Veja. Pesquise. Conheça. $\quad$ [8-B] Esta Casa é sua pelo mandado popular. Defenda o Parlamento. Mãos à obra. Boa sorte.

Esta Casa também é sua.

Em [9-A], a força ilocucionária (convite) em relação ao cidadão não se repete em relação ao Parlamentar. Ao visitante, conforme explica Searle (1969), o ato é diretivo: tenta levar o interlocutor a agir de determinada forma. Mas também, novamente, como em toda a mostra, busca a identificação com o cidadão, e sua cumplicidade. Ao Parlamentar [8-B], também o ato é diretivo, no sentido de convocá-lo ao trabalho: "Mãos à obra."

Enfim, na persecução do gênero discursivo em que se enquadram os textos estudados, percorremos longo caminho na análise, primeiro, dos lugares de fala dos participantes discursivos e, segundo, dos elementos componentes da organização textual. Parte-se então, finalmente, em busca do entendimento dos propósitos reconhecidos ou finalidades identificadas, estabelecidas no evento social. O próximo, portanto, é o último passo do método proposto por Kress para o estudo dos gêneros textuais (Kress, 1989, p. 19).

\subsubsection{Das finalidades ou propósitos reconhecidos}

Todo esse esforço de enquadramento dos textos sob análise em delimitação de gênero resolve-se, em nosso entendimento, na identificação dos propósitos reconhecidos nos textos em análise. Vale lembrar que o gênero, para Kress (1989), é um tipo de texto que codifica traços característicos dos eventos sociais, estruturas dos eventos sociais e os propósitos dos participantes envolvidos. Para o entendimento desses propósitos, voltamos às bases da própria Teoria Semiótica Social.

Conforme já anunciamos, para Kress \& van Leeuwen (1996) a comunicação requer que o criador de signos, no momento da produção dos signos, busque a forma que considera mais apta e plausível, num determinado contexto de comunicação, para representar o que deseja que seja representado, visando ao entendimento máximo da mensagem elaborada. $\mathrm{O}$ 
signo semiótico, diferentemente do linguístico, é motivado. Nasce, portanto, com um propósito, uma finalidade, com base em seleção criterial priorística. E a comunicação estabelece, na estrutura social, lugares inevitavelmente marcados por diferenças de poder, o que não só afeta a noção de entendimento máximo pelos participantes como também permite ao participante em posição de poder impor maior esforço de interpretação, conforme seu interesse.

Por meio da aplicação das bases teóricas da TSSM, entende-se o criador de signos como a instituição Câmara dos Deputados do Brasil, por meio de sua Secretaria de Comunicação Social $^{27}$, órgão que se reporta diretamente à Presidência da Câmara dos Deputados $^{28}$, então exercida pelo Deputado Eduardo Cunha.

Este órgão buscou a forma que considerou mais apta e plausível para representar o que queria fosse representado. A seleção de determinada forma não se deu, e não se poderia dar, de modo neutro, considerando as conformações político-ideológicas da prática discursiva. Assim, a forma eleita como a mais apta e plausível foi uma exposição histórica ou mostra cultural, composta por textos multimodais, em estrutura multidimensional (VAN LEEUWEN, 2005, p. 109). Toda a análise discursiva e multimodal dos elementos componentes da organização textual evidencia o formato de exposição ou mostra, contudo, não menos evidentes se manifestaram os propósitos político-ideológicos expostos.

Este enquadramento da exposição histórica como forma de representação nos leva a ponderar se, consideradas as condições espistemológicas que embasam este estudo, a exposição se consistiria em gênero discursivo assim nominável, ou seja, gênero ligado a uma esfera discursiva ou formação discursiva determinada: a esfera artística e/ou cultural.

Abre-se indispensável parêntese para esclarecer que se evoca sentido restrito para a dita esfera artística e/ou cultural — e assim se a considerou em toda a análise —, pois se poderia validamente aduzir que um evento social e discursivo atrelado às esferas artística e/ou cultural invariavelmente guarda talante de discurso político e ideológico. Assim se poderia

${ }^{27}$ Faz parte da Secom o Centro Cultural Câmara dos Deputados, ao qual "compete tratar dos aspectos relacionados ao planejamento, coordenação, orientação, direção, supervisão, produção, curadoria e controle dos assuntos relativos: à historiografia parlamentar e à história da arte; à museologia e à museografia; às exposições históricas e institucionais que tratam das atividades da Câmara dos Deputados e da produção legislativa; aos eventos, exposições, mostras culturais e atividades relacionadas a projetos sociais e projetos da instituição que tratam das artes plásticas, cênicas, cinematográficas, fotográficas, literárias e musicais, e dos gabinetes de arte [...]". Fonte: <http://www2.camara.leg.br/a-camara/estruturaadm/secom/estrutura>. Acesso em 12 set 2015.

${ }^{28} \mathrm{Cf}$. <http://www2.camara.leg.br/a-camara/estruturaadm/secom/estrutura.> 
arguir em relação a todo evento social, caso se considerem superiores as esferas políticas e ideológicas. Entenderemos, portanto, a cultura na sua acepção mais restrita, ou seja, aquela que entende a cultura como atividade ligada à arte, à história, à intelectualidade.

Bakhtin (apud RODRIGUES 2005, p. 169) menciona a esfera artística quando trata dos gêneros secundários, relacionando-os a situações comunicativas mais complexas que "surgem nas condições da comunicação cultural mais 'complexa', no âmbito das ideologias formalizadas e especializadas, que, uma vez constituídas, 'medeiam' as interações sociais: na esfera artística, científica, religiosa, jornalística, escolar, etc.” Assim, poder-se-ia, em paráfrase, admitir que a esfera artística constitui-se em instância de "ideologias formalizadas e especializadas" a intermediar as relações entre os agentes comunicativos. Voltando a Bakhtin, se o que distingue os gêneros secundários (dos primários) é a situação de interação e o enquadramento desta em determinada esfera discursiva, além da finalidade e da concepção de autor e destinatário da comunicação social, imperioso atestar cada um desses elementos como relacionados à esfera artística ou cultural, para que se faça o devido enquadramento de gênero.

$\mathrm{Na}$ esfera artística, exposição ou mostra cultural poder-se-ia configurar como gênero do discurso, pela situação de interação. Contudo, há algo na concepção de autor e destinatário da comunicação social (Parlamento, de um lado, e parlamentares e cidadãos, de outro lado) que indica quebra de paradigma naquilo que se pode considerar exposição mostra ou cultural. Ademais, a finalidade do evento discursivo, ou o seu escopo, em nosso entendimento, ultrapassa a esfera artística e estende-se muito além do que se pretenderia obter de uma exposição histórica, alcançando plena e fulminantemente a esfera política.

Daí exsurgem os efeitos ideológicos subjacentes e ocultos (a redundância é proposital, tendo em vista a aparente contradição na forma de representação), fim último da luta pelo poder hegemônico, do qual Bourdieu (2006, p. 14) trata com maestria:

O efeito propriamente ideológico consiste precisamente na imposição de sistemas de classificação políticos sob a aparência legítima de taxinomias filosóficas, religiosas, jurídicas, etc. Os sistemas simbólicos devem sua força ao facto de as relações de força que neles se exprimem só se manifestarem neles em forma irreconhecível de relações de sentido (deslocamento).

Se o elemento teleológico se mostra capaz da delimitação genérico-discursiva, 
também o contexto de comunicação, no momento da produção dos signos, indica gênero discursivo afeito à esfera política, muito além da artística ou cultural. A crise de representatividade por que então passam os Poderes Legislativo e Executivo, as incertezas advindas das manifestações populares recentes (por isso, ainda incompreendidas) e constantes, os perigos à estabilidade econômica recém-adquirida pelo País, advindos da crise econômica e política no Brasil e também no mundo, as ameaças latentes ao regime democrático, por meio de um clamor nada silencioso pela volta de regimes militares: todos os fatores sociais e históricos que campeiam o evento discursivo prestam-se a demarcá-lo como inserto em gênero (ainda inominado) da esfera política: antes atividade de cunho político que atividade de cunho artístico-cultural. Assim, como forma de representação, a mostra cultural poderia servir como suporte para o discurso político, este, sim, detentor de todos os elementos caracterizadores do gênero (KRESS, 1996): finalidade (intenção, propósito), lugares de fala dos participantes discursivos e organização textual.

Para Wittgenstein (1953, p. 108), "uma intenção encarna-se numa situação, em costumes e em instituições humanas”. Quanto à intenção política, novamente nos socorre Bordieu (2006, p. 165, itálico no original):

A intenção política só se constitui na relação com um estado do jogo político
e, mais precisamente, do universo das técnicas de ação e de expressão que
ele oferece em dado momento. Neste caso, como em outros, a passagem do
implícito ao explícito, da impressão subjetiva à expressão objetiva, à
manifestação pública num discurso ou num ato público constitui por si só
um ato de instituiçãao e representa por isso uma forma de oficialização, de
legitimação [...]

Técnicas de ação e de expressão do jogo político nas quais se investe a intenção política roboram o entendimento de que certa mostra cultural poderia servir de suporte a discurso político. Há que se notar que textos produzidos e distribuídos pela Câmara dos Deputados, sob tal chancela, carregam os atributos da institucionalidade e da oficialidade. Ungem-se de legitimidade - mesmo que a Casa esteja sob suspeição popular, pela aleivosia e perfídia de alguns de seus membros, investigados por corrupção.

Ainda que se a considere ínclita a uma particular configuração genérica (de gênero, o gênero exposição ou mostra cultural), propugnamos que esta estaria subordinada a um gênero maior, o gênero discurso político, o que para Kress configura o fenômeno do hibridismo dos gêneros de discurso, resultante da multiplicidade de formações discursivas 
(artísticas/históricas/políticas/ideológicas/institucionais públicas).

No caso do hibridismo, a análise faircloughiana certamente se faria com base na noção de interdiscursividade (intertextualidade constitutiva), pois constituem o discurso político recursos semióticos característicos de um gênero diverso. A luta pelo poder hegemônico propiciaria o emprego de mecanismos sociais para a constituição de discurso reconfigurado (o discurso político), a partir de tipos previamente existentes (a mostra cultural). A visão bakhtiniana de gênero aponta para a criatividade e a inovação como atributos potenciais inerentes ao gênero do discurso.

Impede, destarte, indagar: poder-se-ia apontar para a emergência de discurso híbrido de informação e publicidade, caso se considerasse, neste último caso, uma espécie de "propaganda institucional”? Permite-se dizer que haveria indícios de comodificação (FAIRCLOUGH, 2001, p. 151) do discurso público institucional, na medida em que se vislumbram efeitos gerais de uma marquetização sobre as ordens de discurso institucionais?

Fairclough (2001) fala de uma reestruturação penetrante de ordens de discurso institucionais (neste caso, afeitas à publicidade e ao mercado), que ocorreria como efeito do impacto do movimento colonizador do discurso da publicidade e do mercado. Cremos ser esta uma interpretação bastante plausível para o fenômeno híbrido que se descortina neste exame. Cada vez mais recorrentes em ordens de discurso institucionais, os textos que simultaneamente informam e publicizam atestam o movimento colonizador da publicidade de mercado para domínios novos, inclusive para o domínio da comunicação levada a cabo pelas instituições do Estado. Essas novas configurações, esse hibridismo discursivo que leva aos textos públicos institucionais configurações discursivas atreladas a textos propagandísticos no caso, a propaganda institucional — testificam a tendência à comodificação vaticinada por Fairclough (2001, p. 151).

Ao tratar da representação política, assim descreve Bourdieu (2006, p. 164) o campo político:

O campo político é o lugar em que se geram, na concorrência entre os agentes que nele se acham envolvidos, produtos políticos, problemas, programas, análises, comentários, conceitos, acontecimentos, entre os quais os cidadãos comuns, reduzidos ao estatuto de consumidores, devem escolher, com probabilidades de mal-entendido tanto maiores quanto mais afastados estão do lugar de produção. 
Não se pode deixar de dizer que, ao se optar por uma exposição ou mostra cultural, em detrimento de um texto com explícito viés político, certamente se estará "desarmando" os ânimos, que normalmente estariam alerta ou preventos diante de um discurso que se autodeclarasse político e institucional. A atitude do leitor diante de iminente leitura de texto político não se pode igualar à postura deste mesmo leitor ante uma exposição de arte ou cultural. Mitiga-se, por meio da máscara cultural, um propósito político hegemônico avassalador.

Vale dizer, enfim, que o discurso publicitário é um discurso estratégico (FAIRCLOUGH, 2001, p. 259), nos termos de Habermas (1984), que opõe este a um discurso dito meramente comunicativo. O discurso político-midiático da instituição pública, cada vez mais aparelhado, espraiado e poderoso, emprega as técnicas afeitas à ordem do discurso publicitário, um efeito da tecnologização do discurso institucional público. Para Fairclough (2001, p. 265), “as tecnologias discursivas estabelecem uma ligação íntima entre o conhecimento sobre linguagem, discurso e poder". Neste discurso, que combina, de forma criativa, informação (histórica) e persuasão, os textos no modo escrito e imagético - embora os sentidos construídos pelas imagens visuais, em relação aos textos escritos, possam ser mais poderosos e imediatos que os da língua em determinado evento social - foram capazes de evocar estilos de vida ou, ainda melhor para este estudo, estilos desejáveis de conduta cidadã e parlamentar.

Fairclough (2001, p. 127) aponta a relação entre criatividade e intertextualidade nos seguintes termos:

\begin{abstract}
A intertextualidade e, portanto, a historicidade inerente da produção e interpretação textual constituem a criatividade como opção. A mudança envolve formas de transgressão, o cruzamento de fronteiras, tais como a reunião de convenções existentes em novas combinações, ou a sua exploração em situações que geralmente as proíbem.
\end{abstract}

Ao optar pela produção de uma exposição de arte ou mostra cultural, a Secretaria de Comunicação da Câmara dos Deputados recorreu à inovação como forma de ultrapassar um “dilema" ou "problema", qual seja, o de transmitir um conteúdo político e ideológico institucional de forma naturalizada. $\mathrm{E}$ o fez, de fato, por meio da hibridização de gêneros. $\mathrm{O}$ emprego de um gênero por outro - ou, mais precisamente, de certos elementos da ordem do 
discurso (gênero, discurso e estilo) que caracterizam um gênero — intenta, e decerto obtém êxito, mitigar a relação de hierarquia, poder e dominação que exerce um dos Poderes da República em relação ao cidadão comum, por um lado. Por outro lado, mostra aos Parlamentares a força do grupo hegemônico na Câmara dos Deputados do Brasil.

Considerando a composição dos gêneros segundo Bakhtin (1992), que coincide com a do enunciado singular, pode-se aduzir que, de fato, o objeto discursivo e a finalidade discursiva permanecem políticos e institucionais no texto, assim como são de cunho político os textos a que se recorreu para a montagem da exposição. Contudo, inova-se no estilo, pois o emprego de recursos típicos dos discursos políticos apaga-se, dando lugar a um texto típico da indústria publicitária e da indústria da arte. Da mesma forma, da ordem publicitária e artística deriva a composição do texto expositivo, ou seja, os procedimentos que organizam e dispõem os recursos semióticos empregados na mostra objeto desta análise discursiva crítica, o que Bakhtin (Ibid.) chama de "acabamento da totalidade discursiva".

Quanto à relação entre os participantes da comunicação discursiva, o hibridismo de gênero mascara a distância e a hierarquia existentes entre a instituição pública estatal e o mero cidadão, de um lado (o texto do panfleto é dirigido aos visitantes da exposição, em geral), e entre a instituição e seus próprios membros, de outro (o texto principal da exposição é o de boas-vindas aos novos Parlamentares). Thompson (1995) poderia apontar, neste propósito, a estratégia típica de construção simbólica denominada dissimulação, que se faria por meio da eufemização. Defendemos que todo o texto da exposição se constrói em torno deste poderoso modo de operação da ideologia, tendente a suavizar, de modo deliberado, a expressão de um discurso substancialmente político-partidário, substituindo-o por outro mais palatável ou tolerável: o discurso cultural, histórico, artístico.

Buscou-se, dessa forma, mitigar ou mascarar a finalidade e o objeto político, o que possibilitou tornar os receptores muito mais vulneráveis ou permeáveis aos sentidos construídos pelos recursos semióticos utilizados na composição. Desarmados, os habitués dos corredores da Câmara dos Deputados, especialmente do que dá acesso ao plenário, tornam-se receptores passivos e maleáveis diante de uma "ingênua" e "despretensiosa" mostra de arte, que proclama a sua clara e nobre intenção de contar a história do Parlamento e da Democracia — nada mais, nada menos. 


\section{CONSIDERAÇÕES FINAIS}

O longo percurso de análise deste trabalho, que se iniciou na análise sócio-histórica e situacional, permitiu-nos responder à primeira questão de pesquisa: os fenômenos da convergência digital e da multimodalidade refletem alterações na ordem do discurso e na caracterização do gênero do discurso da mídia político-institucional? A resposta é positiva: sim, os fenômenos da convergência digital ou cultural e da multimodalidade espelham as alterações nas atividades sociais ligadas à mídia político-institucional. Mas, mais do que isso, não só refletem essas mudanças como as retroalimentam, através dos meios tecnológicos e comunicacionais disponíveis na era da cultura de massa, na era da cultura das mídias e, mais contemporaneamente, na era da cultura digital (SANTAELLA, 2003). A pesquisa, portanto, ampliou a formulação proposta pela questão de pesquisa, expandindo-a no sentido de revelar que a mudança na ordem do discurso institucional acompanha-se de ampla reestruturação, expansão e engrandecimento da própria mídia parlamentar e demais ações conduzidas pelo grupo hegemônico naquela Casa de Leis.

Por conseguinte, também positiva é a resposta ao questionamento em relação à democracia como elemento de constrição da ordem do discurso político institucional. A análise das estratégias discursivas empregadas, bem assim do emprego de recursos semióticos de modos distintos (escrito e imagético) mostrou à sobejidão que a democracia, ou melhor ainda, a defesa do regime democrático significa a defesa da própria condição de existência do Parlamento. Por isso, muito mais do que tema central, identificado no corpus de análise, a democracia é o propósito último de toda ação parlamentar e, a partir da noção de democracia e consoante esta noção, configuram-se os gêneros discursivos atrelados às atividades ali desenvolvidas. A democracia conforma-se, enfim, como o fundamental elemento de constrição da ordem do discurso parlamentar.

Para essa defesa discursiva e semiótica do Parlamento, o discurso político precisou reinventar-se, reconfigurar-se em novo gênero, um gênero híbrido, caracterizado pela abundância e integração de recursos semióticos. Esse movimento de adequação discursiva revela, sim, as alterações profundas e inescapáveis em curso na produção, na distribuição e no consumo dos textos midiáticos da Câmara dos Deputados do Brasil, o que significa mudanças nas próprias práticas discursivas do Parlamento. Eis que se responde, também positivamente, 
à terceira questão de pesquisa.

Em sua magistral obra, Habermas (2003) discorre acerca da separação das esferas pública e privada como marco do contexto moderno. No Novo Capitalismo (FAIRCLOUGH, 2003), as mudanças nas redes de práticas sociais e nas formas de ação e interação aprofundam-se e recrudescem-se, e incluem alterações nos gêneros discursivos, "importantes para a sustentação da estrutura institucional da sociedade contemporânea, nas relações estruturais entre governo (local), comércio, universidades, mídia.” As lutas ideológicas ganham espaço nas cadeias de gêneros que se misturam e combinam, surgindo gêneros híbridos e de prestígio, como os de governança, que buscam regular ou gerenciar outras instituições ou organizações, ou (redes de) práticas sociais, verbi gratia os gêneros promocionais de marcas, produtos, organizações ou indivíduos.

A busca pelo domínio dos meios de comunicação de massa espraiou-se por todas as instituições da sociedade e do Estado, chegando à Casa de Leis com toda a força desta nova era digital. As forças políticas hegemônicas no Parlamento não tardaram a compreender que "a capacidade de influenciar ou controlar processos de mediação é um importante aspecto do poder nas sociedades contemporâneas" (FAIRCLOUGH, 2003). E para Giddens (1990), poder é a "capacidade de assegurar resultado onde a realização desses resultados depende da ação de outros".

O que se pode assinalar com gravidade é a mudança profunda de significados e representações. Se na esfera pública os meios de comunicação sempre foram usados para fins públicos ou políticos, na mídia estatal, os fins políticos vão-se imbricando em produtos de mídia cujos fins eram puramente públicos, de cunho democrático. Das atividades de mero registro das atividades do Plenário e das Comissões Temáticas nos Anais da Câmara dos Deputados, e da divulgação dos projetos em discussão e votação na Casa, a comunicação política na Casa de Leis evoluiu e evolui ainda, substancialmente. Expandiu-se, inicialmente, com a divulgação de atividades institucionais (além das legislativas), como a agenda do Presidente e dos partidos políticos, o relacionamento do Parlamento com os outros Poderes da República, também com outros Parlamentos do mundo, a relação do Parlamento com outras instituições públicas e sociais. Mas continuou expandindo-se. Hoje, além de notícias legislativas e institucionais, produz extenso e diversificado conteúdo, também social e cultural. E, nessa expansão, os propósitos políticos foram contaminando todas as produções da comunicação pública, e mesmo a mais simples exposição histórico-cultural — que, tempos 
atrás, passados apenas uns 15 anos, poderia de fato ser mostra cultural e artística — deixa de ser meramente cultural para convolar-se em discurso político em essência, mais especialmente discurso político-partidário.

Ademais, a exposição ressemiotiza-se em ambiente virtual, recontextualiza-se e ressignifica-se, em múltiplas outras plataformas ou suportes. Não mais limitada fisicamente pelos corredores da Casa de Leis, onde foi exposta, reproduz-se na página virtual da Casa e transforma-se num produto não só da mídia de massa, mas também da mídia digital (SANTAELLA, 2003a). O discurso político reinventa-se e encontra outros refúgios para esconder-se e, assim, ganhar em eficiência e alcance.

Portanto, apontado o problema, pode-se aduzir, sem hesitação: falar no discurso da instituição pública estatal e dos textos produzidos por órgãos midiáticos da comunicação pública (estatal) implica aproximá-los, e ao mesmo tempo diferenciá-los, aos da comunicação privada e de mercado. A questão, como se pôde verificar nesta análise linguístico-semiótica, não é de simples compreensão, como de resto permanece complexo o entendimento das práticas sociais e discursivas da modernidade líquida (BAUMAN, 2001).

A voz do Parlamento não parece querer mitigar as disputas e diferenças havidas dentro e fora do Parlamento, na relação deste com os outros Poderes. E, embora os sentidos construídos pelos textos multimodais da mídia parlamentar não explicitem os reais propósitos políticos e ideológicos nessa luta intrincada, seus meandros se deixam penetrar pela análise discursiva crítica e multimodal, que pouco identifica nesses discursos estratégias voltadas ao entendimento, à solução e ao consenso.

Neste ponto, cresce em importância o trabalho do analista social discursivo crítico, no sentido de ir desfazendo esse emaranhado de gêneros híbridos e mistos que se vão formando com a emergência de fenômenos como a convergência das mídias e a multimodalidade, considerando as implicações deontológicas intrínsecas ao papel das mídias (oficiais e mercadológicas) nas democracias modernas. 


\section{REFERÊNCIAS}

ARENDT, Hannah. Entre o passado e o futuro. Trad. Mauro W. Barbosa de Almeida. São Paulo: Perspectiva, 1972.

AUSTIN, J.L. Cómo hacer cosas com palabras. Barcelona: Ediciones Paidós, 1998.

AUTHIER-RÉVUZ, J. Heterogeneidade mostrada e heterogeneidade constitutiva: elementos para uma abordagem do outro no discurso. In: Authier-Revuz, Jacqueline. Entre a transparência e a opacidade: um estudo enunciativo do sentido. Porto Alegre: EDIPUCRS, [1982] 2004.

BRASIL. Câmara dos Deputados. Secretaria de Comunicação Social. Convergência e integração na comunicação pública. (Org.) Evelin Maciel. Brasília: Câmara dos Deputados, Edições Câmara, 2013, 158 p. Série gestão institucional/Relatórios, n. 3.

BAKHTIN, M. M. Marxismo e filosofia da linguagem. São Paulo: Hucitec, 1992 [1929].

Problemas da poética de Dostoiévski. 2. ed. Ver. Rio de Janeiro: Forense Universitária, 1997 [1929].

Os gêneros do discurso. In: Estética da criação verbal. Trad. P. Bezerra. São Paulo: Martin Fontes, 2003 [1952-1953].

O discurso no romance. In: Questões de literatura e estética. A teoria do romance. Trad. A.F. Fernadini et al. 6. ed. São Paulo: Hucitec, 2010.

BALDRY, A.; THIBAULT, P. J. Multimodal transcription and text analysis: a multimedia toolkit and coursebook. London: Equinox, 2006.

BOLTER, J. D. Writing Space. The Computer, Hypertext, and the Hystory of Writing. Hillsdale, N.J.: Lawrence Erlbaum Associates, 1991.

BARROS, G. L. P. Contribuições de Bakhtin às teorias do texto e do discurso. In: FARACO, C.A.; TEZZA, C.; CASTRO, G. (Orgs.) Diálogos com Bakhtin [1996]. Curitiba: Editora da UFPR, 2001.

BAUER, Martin W.; GASKELL, George (Org.). Pesquisa qualitativa com texto, imagem e som: um manual prático. 2a ed. Petrópolis, RJ: Vozes, 2002.

BAUMAN, Z. Modernidade Líquida. Rio de Janeiro: Zahar, 2001.

BAZERMAN, C. Atos de fala, gêneros textuais e sistemas de atividades: como os textos organizam atividades e pessoas. In: BAZERMAN, C. Gêneros textuais, tipificação e interação. Trad. Judith Chambliss Hoffnagel. São Paulo: Cortez, 2005.

BEZERRA, M. A. (Org.) O Livro Didático de Português: múltiplos olhares. 2. ed. Rio de Janeiro: Lucerna, 2003. 
BALLOCO, A.E. A Perspectiva Discursivo-Semiótica de Gunther Kress. In: MEURER, José Luiz; BONINI, Adair; MOTTA-ROTH, Desirée. (Orgs.) Gêneros: teorias métodos, debates. São Paulo: Parábola Editorial, 2005.

BONFIM, J.B.B. Palavra de Presidente: discursos de posse de Deodoro a Lula. Brasília: LGE Editora, 2004.

BOURDIEU, P. O poder simbólico. 9. ed. Rio de Janeiro: Bertrand Brasil, 2006.

CASTELLS, M. A sociedade em rede. São Paulo: Paz e Terra, 1999.

Redes de indignação e esperança: movimentos sociais na era da internet.

Trad. Carlos Alberto Medeiros. Rio de Janeiro: Zahar, 2013

CHARADEAU, P. Discurso Político. 1. ed. São Paulo: Contexto, 2006.

CHEVAllieR, J.J. As Grandes Obras Políticas: De Maquiavel a nossos dias. 5 ed. Rio de Janeiro: Editora Agir, 1990.

DERRIDA, J. A escritura e a diferença. São Paulo: Perspectiva, 1971.

FAIRCLOUGH, N. Discurso e Mudança Social. (Coord. Trad.) Izabel Magalhães. Brasília: Editora Universidade de Brasília, 2001.

Analysing discourse. Textual analysis for social research. Proceedings. London: Routledge, 2003.

; FAIRCOUGH, I. Political Discourse Analysis: a Method for Advanced Students. London: Routledge, 2012.

Language and globalization. London: Routledge, 2006.

Language and power. London: Longman, 1989.

; WODAK, R. Critical discourse analysis. In: VAN DIJK, T. A. (Ed.). Discourse as social interaction. London: Sage, 1997.

; CHOULIARAKI, L. Discourse in late modernity: rethinking critical discourse analysis. Edinburgh: Edinburgh University Press, 1999.

FARACO. C. A; TEZZA. C; CASTRO. G de. (Orgs). Diálogos com Bakhtin. Paraná: UFPR, 1996.

FERRAZ, J.A. Multimodalidade e Formação Identitária: o Brasileiro em Materiais Didáticos de Português Língua Estrangeira (PLE). In: Reflexões sobre a língua portuguesa: um aabordagem multimodal. VIEIRA, J.A. et al. Petrópolis, Rio de Janeiro: Vozes, 2007. 
novas perspectivas discursivas críticas. 2011. 197 f., il. Tese (Doutorado em Linguística) Universidade de Brasília, Brasília, 2011.

FOUCAUlT, M. A Ordem do Discurso. 13. ed. São Paulo: Edições Loyola, 2006. . História da loucura na Idade Clássica. São Paulo: Perspectiva, 1972.

FOWLER, R.; HODGE, B.; KRESS, G; TREW, T. Language and control. Londres: Routledge, 1979.

GIDDENS, Anthony. The consequences of modernity. Cambridge, Polity, 1990.

HABERMAS, Jürgen. Mudança estrutural da esfera pública: investigações quanto a uma categoria da sociedade burguesa. Rio de Janeiro: Tempo Brasileiro, 1984.

Direito e democracia: entre facticidade e validade. Trad. De Flávio

B. Siebeneichler. Rio de Janeiro: Tempo Brasileiro, 2003. (2003 v.I \& 2003 v.II)

HALLIDAY, M.A.K. An introduction to functional grammar. London: Hodder Arnold: 1985.

HALLIDAY, M.A.K. Introduction to Functional Grammar. 2. ed, London: Edward Arnold, 1994.

HODGE, R., KRESS, G. Social Semiotics. London: Polity Press, 1988.

IEDEMA, R. Multimodality, resemiotization: extending the analysis of discourse as multisemiotic practice. Visual communication, v. 2, n. 1, p. 29-57, 2003.

JEWITT, C ; OYAMA, R. Visual Meaning: a Social Semiotic Approach. In: Handbook of Visual Analysis. VAN LEEUWEN, T. ; JEWITT. C. London: SAGE Publications Ltd., 2004.

KRESS, G. Design and transformation: new theories of meaning. In: COPE, B.; KALANTZIS, M. Multiliteracies: Literacy learning and the design of social futures. London: Routledge, 2000.

History and Language: towards a social account of linguistic change. Journal of Pragmatics, v. 13, n. 3, p. 445-466, 1989.

Writing the future: English and the Making of a Culture of Innovation. New

York: Routledge, 1995.

Multimodality: a social semiotic approach to communication. London \& New York: Routledge, 2010. 
; VAN LEEUWEN, T. Multimodal Discourse: The modes and media of contemporary communication. London: Arnold, 2001.

; VAN LEEUWEN, T. Reading Images: The Grammar of Visual Design.

Londres: Routledge, 1996.

; VAN LEEUWEN, T. Colour as a semiotic mode: notes for a grammar of colour. UK: Cardiff University, 2002.

KRESS, G.; LEITE-GARCIA, R.; VAN LEEUWEN, T. Semiótica Discursiva. In: van DIJK, T. A. El discurso como estructura y processo. Barcelona: Gedisa Editorial, 2000.

MACEDO, D.S. As Contribuições da Análise de Discurso Crítica e da Multimodalidade à Revisão Textual. (Dissertação). Universidade de Brasília: 2013.

MACHADO, Irene. Gêneros discursivos. In: Bakhtin Conceitos Chave. $4^{\mathrm{a}}$ ed. São Paulo: Contexto, 2008.

MAINGUENEAU, D. Análise de Textos de Comunicação. Trad. Maria Cecília de Souza-eSilva, Décio Rocha. 6. ed. São Paulo: Cortex, 2013.

MARTINO, L.M.S. Teoria das Mídias Digitais: linguagens, ambientes, redes. Petrópolis, Rio de Janeiro: Vozes, 2014.

MATEUS, M. et al.Gramática da Língua Portuguesa. Lisboa: Caminho, 2003.

MARCUSCHI. L. A. Produção textual, análise de gêneros e compreensão. São Paulo: Parábola Editorial, 2008

Compreensão de texto: algumas reflexões. In: DIONÍSIO, A. P.; MACHADO, A.R.; BEZERRA, M.A. Gêneros textuais e ensino. 4. ed. Rio de Janeiro: Lucerna, 2006.

Gêneros textuais emergentes no contexto da tecnologia digital. In MARCUSCHI, Luiz Antônio. XAVIER, Antonio Carlos (Orgs.). Hipertexto e gêneros digitais: Novas formas de construção de sentido. São Paulo: Cortez, 2010.

MARTÍN-BARBERO, J. Os Exercícios do Ver: Hegemonia Audiovisual e Ficção Televisiva. São Paulo: Editora Senac, 2004.

MEURER, José Luiz; BONINI, Adair; MOTTA-ROTH, Desirée. (Orgs.) Gêneros: teorias métodos, debates. São Paulo: Parábola Editorial, 2005. 
NEVES, Maria Helena de Moura. A Vertente Grega da Gramática Tradicional. Brasília: Editora Universidade de Brasília. 1987.

PAIVA, C.G. Uma viagem pelo discurso parlamentar: gênero discurso por desvendar. In: Discurso, identidade e gênero. VIEIRA, J.A.; BENTO, A.L. (Orgs.) Brasília: Editora Movimento, 2015.

PARÉ, A.; SMART, G. Observing Genres in Action: Towards a Research Methodology. In: FREEDMAN, A; MEDWA, P. (Orgs.) Genre and the New Rhetoric. London: Taylor \& Francis, 1994.

PÊCHEUX, M. Sur la (dé)construction des theóries linguistiques. D.R.L.A.V. n. 27, p.124, 1982.

PERRONE-MOISÉS, L. A intertextualidade crítica. Tradução de Clara Crabbé Rocha. In: JENNY, L. et al. Intertextualidades - Poétique n²7. Coimbra: Almedina, 1979.

RAJAGOPALAN, K. A insustentável seriedade da leveza: uma análise desconstrutiva do humor de J.L. Austin., 08/1992, DELTA. Documentação de Estudos em Linguística Teórica e Aplicada (PUCSP. Impresso), Vol. 8, Fac. 2, pp.291-301, São Paulo, SP, BRASIL, 1992.

ROCHA, H. Um novo paradigma de revisão de texto: discurso, gênero e multimodalidade. 2012. xi, 246 f., il. Tese (Doutorado em Linguística)—Universidade de Brasília, Brasília, 2012.

RODRIGUES, R. H. Os gêneros do discurso na perspectiva dialógica da linguagem: a abordagem de Bakhtin. In: MEURER, J.L.; BONINI, A.; MOTTA-ROTH, D. Gêneros: teorias, métodos e debates. São Paulo: Parábola Editorial, 2005.

ROJO, R. Gêneros do Discurso e Gêneros Textuais: questões teóricas aplicadas. In: Gêneros: teorias, métodos, debates. MEURER, J.L.; BONINI, A. MOTTA-ROTH, D. (Orgs.). São Paulo: Parábola Editorial, 2005.

SANTAELLA, L. A Cultura das Mídias. São Paulo: Experimento, 1996.

Culturas e artes do pós-humano: Da cultura das mídias à cibercultura.

São Paulo: Paulus, 2003a.

Da cultura das mídias à cibercultura: o advento do pós- humano.

Revista FAMECOS. Porto Alegre, n.22, dez 2003. quadrimestral.

SAUSSURE, F. Curso de linguística geral. Organização de Charles Bally e Albert Sechehaye com a colaboração de Albert Riedlinger. Trad. Antônio Chelini, José Paulo Paes e Izidoro Blikstein. 24. ed. São Paulo: Pensamento-Cultrix, 2002. 
SCHINFFRIN, D. Approaches to discourse. London: Blackwell, 1994.

SEARLE, J. R. Speech acts: na essay in the philosophy of language. Cambridge: At the University Press, 1969.

SILVA, J. A. Curso de Direito Constitucional Positivo. 6. ed., São Paulo: Revista dos Tribunais, 1990.

THOMPSON, J. B. Ideologia e cultura moderna: teoria crítica na era dos meios de comunicação de massas. 6. ed. Petrópolis, RJ: Vozes, 1995.

VAN LEEUWEN, T.. Introducing social semiotics. London/New York: Routledge, 2005.

VIEIRA, J. A. Novas perspectivas para o texto: uma visão multissemiótica. In: VIEIRA, J. A. et al. Reflexões sobre a Língua Portuguesa: uma abordagem multimodal. Petrópolis, RJ: Vozes, 2007.

Afinal, existem metáforas visuais? In: VIEIRA, J. A.; LÚCIO, A. L.; ORMUNDO, J. S. (Orgs.). Discurso nas práticas Sociais. São Paulo: Anablume, 2010.

- SILVESTRE, C. Introdução à Multimodalidade: contribuições da Gramática Sistêmico-Funcional, Análise de Discuro Crítica, Semiótica Social. Brasília: J. Antunes Vieira, 2015.

VAN DIJK, T.A. Racismo e Discurso na América Latina. São Paulo: Contexto, 2008.

WERNICK, A. Promotional Culture: advertising, ideology and symbolic expression. London and Newbury Park: Sage Publications, 1991.

WITTGENSTEIN, L. Philosophical Investigations. New York: Macmillan, 1953. 